\title{
Theory and Practice of Sanctions Strategy and Effectiveness: Influencing Russian Foreign Policy
}

\author{
By \\ Demyan Plakhov
}

A thesis submitted to the Faculty of Graduate and Postdoctoral Affairs in partial fulfillment of the requirements for the degree of

Master of Arts in

European, Russian, and Eurasian Studies

Carleton University

Ottawa, Canada

(C) 2020

Demyan Plakhov 


\begin{abstract}
This master thesis will review the case of contemporary sanctions implemented against Russia by the European Union (EU) with regards to its Ukraine foreign policy, which will assist in determining the effectiveness of sanctions imposed in this specific case. This thesis considers sanctions implemented against Russia as not effective thus far, since sanctions have yet to force a change in Russia's foreign policy. The lack of effectiveness lies with Russia's unique capabilities that enable it to resist sanctions, in combination with major gaps in the EU's sanctions strategy towards Russia. This thesis utilizes the contemporary EU-Russia case to test and expand on Nephew's and Miyagawa's framework of sanctions effectiveness, and discovers a new realm of sanctions categorization beyond the traditional spectrum of 'effective' and 'ineffective' sanctions regimes - sanctions regimes with inadvertent effects.
\end{abstract}




\section{Acknowledgements}

I would like to thank Dr. Crina Viju for her consistent help, expertise, kindness, and attentiveness to my project. Her guidance was central to the completion of this project, and her continual steadfast confidence in the project was always greatly reassuring and appreciated. I am grateful for Dr. Joan DeBardeleben's positive feedback from the beginning, which was critical to maintaining my motivation to consistently improve and to look to alternative perspectives. Both professors never let me be complacent, challenged my ideas, and showed me the path to more rigorous research. Likewise, I would like to thank Dr. Marta Dyczok who pointed me in the direction of studying this region and taking the time to review this project.

I will never forget the support I received from Dr. Jeff Sahadeo, Krysia Kotarba, and the EURUS Institute. Their leadership, empathy, and compassion is unmatched. This was truly highlighted by their unwavering management during the COVID-19 pandemic - always being at every student's side.

I would like to thank the rest of the EURUS Faculty as well. I was very lucky with my EURUS cohort that managed to stick together while going through similar struggles and victories.

I would like to thank my partner who was always there to support, encourage, and motivate me during my thesis and the cold Ottawa winters. I want to thank my family — including my mom, dad, sister, grandfather, and aunt — for their support, endearment, and love.

Finally, I would like to extend a thank you to all those individuals who took an interest, listened, asked questions, and further pushed my ideas. You provided me the necessary additional motivation to contemplate this topic. 


\section{Table of Contents}

List of Tables

List of Figures

List of Abbreviations

\section{Chapter 1: Introduction to Sanctions, Theory, Background, and Scope of the Project 1}

1.1 Introduction and Research Question

1.2 Scope of the Project

1.3 Theoretical Framework and Hypothesis

1.4 Literature Review of Sanctions and its Evolution 8

1.5 Methodology 20

1.6 What Happened Here and Has It Happened Before? 22

Chapter 2: Reviewing European Union's Sanctions Strategy $\quad 29$

2.1 How and Why the EU Utilizes Sanctions 29

2.2 Type of EU Sanctions $\quad 32$

2.3 Sanctions Against Russia: List of Official Sanctions' Aims 35

2.4 Sanctions' Impact

2.5 Sanctions Impact: Russia's Rejection of Sanctions'Aims 46

2.6 Reviewing EU's Strategy Using Nephew's Framework 53

Chapter 3: Russia's Capabilities and Circumstances $\quad \mathbf{6 7}$

3.1 Introduction to Miyagawa and Russia's Capabilities $\quad 67$

3.2 Russia's Recovery From Sanctions 68

3.3 Russia's Intent to Recover and Counter Sanctions 75

3.4 Miyagawa's Conditions 81

3.5 Additional Conditions $\quad 89$

Chapter 4: Inadvertent Effects of Sanctions $\quad 96$

4.1 Introduction to Inadvertent Effects 96

4.2 Russia's Intent to Counter Sanctions with Responses 97

4.3 Russian Entrenchment and Counter Sanctions 99

4.4 Reinforced Ties with Western Adversaries and Others 102

4.5 Russia Undermine Sender States and Their Alliances 111

4.6 Russia's Increased State Popularity and Anti-Western Sentiment 117

4.7 Conclusions to Inadvertent Effects 122 
Chapter 5: Theoretical and Policy Conclusions

5.1 Theoretical Conclusions from the Research

5.2 Policy Conclusions From the Research

126

5.3 Further Research

130

Bibliography

132

Appendix A

174

Appendix B

179

Appendix C

185

Economic Options for the EU

185

Diplomatic Options for the EU

193

Other Strategic Options for the EU

198 


\section{List of Tables}

Table 1.1: List of Sender States against Russia 174

Table 1.2: Minsk II agreement (13 points translated and summarized by the European Parliamentary Research Service)

Table 2.1: An Evaluation of EU Member States Perspectives on Sanctions Against Russia176 Table 3.1: Applying Miyagawa’s and Additional Conditions to Russia’s Vulnerability 


\section{List of Figures}

Figure 5.1: The Theoretical Spectrum of Sanctions' Effectiveness Based on Target State's Policy Change as a Response to Sanctions 126

Figure 3.1: Russia's GDP compared to Global Oil Prices (2008-2018) 179

Figure 3.2: Russia's Total Trade - in billions USD (1996-2019) 179

Figure 3.3: Real GDP growth - in annual \% change (1980-2020) 181

Figure 3.4: Russia Net Foreign Direct Investment - net in billions of USD (2008-2018) 181

Figure 3.5: Russian Inflation, Consumer Prices - annual \% (2001-2019) 182

Figure 3.6: GNI of Russia and the G7 (not including US) - in trillion USD (2006-2018) 182

Figure 3.7: GNI of Russia, United States, European Union - in trillion USD (2006-2018) 183

Figure 3.8: Map of Vulnerable Shipping Routes 184

$\begin{array}{ll}\text { Demyan Plakhov } & 7\end{array}$ 


\section{List of Abbreviations}

\begin{tabular}{|c|c|}
\hline Abbreviation & Full Name \\
\hline AfD & Alternative for Germany \\
\hline APEC & Asian Pacific Economic Cooperation (APEC) \\
\hline BRI & Belt and Road Initiative \\
\hline BRICS & Brazil, Russia, India, China, and South Africa \\
\hline CAATSA & Countering America's Adversaries Through Sanctions Act \\
\hline CBRN & Chemical, biological, radiological and nuclear \\
\hline CEFIR & Centre for Economic and Financial Research \\
\hline CFSP & Common Foreign and Security Policy \\
\hline CIS & Commonwealth of Independent States \\
\hline COREPER & Committee of Permanent Representatives \\
\hline EBRD & European Bank for Reconstruction and Development \\
\hline $\mathrm{EC}$ & European Community \\
\hline EEAS & European External Action Service \\
\hline EIB & European Investment Bank \\
\hline EPRS & European Parliamentary Research Service \\
\hline EU & European Union \\
\hline FDI & Foreign Direct Investment \\
\hline FOREX & Foreign exchange reserves \\
\hline FPO & Freedom Party of Austria \\
\hline GDP & Gross Domestic Product \\
\hline GIUK & Greenland-Iceland-United Kingdom \\
\hline GNI (or GNP) & $\begin{array}{c}\text { Gross National Income, formerly known as GNP or Gross National } \\
\text { Product }\end{array}$ \\
\hline GRU & Main Intelligence Directorate \\
\hline $\mathrm{ICC}$ & International Criminal Court \\
\hline ICJ & International Court of Justice \\
\hline
\end{tabular}




\begin{tabular}{|c|c|}
\hline ICT & Information and Communications Technology \\
\hline IEA & International Energy Agency \\
\hline IMF & International Monetary Fund \\
\hline ISI & Import substitution industrialization \\
\hline JCPOA & Joint Comprehensive Plan of Action \\
\hline MEP & Member of European Parliament \\
\hline MH17 & Malaysia Airlines Flight 17 \\
\hline NATO & North Atlantic Treaty Organization \\
\hline OECD & Organisation for Economic Co-operation and Development \\
\hline OFAC & Office of Foreign Assets Control \\
\hline OPCW & Organisation for the Prohibition of Chemical Weapons \\
\hline ORT & Public Russian Television \\
\hline OSCE & Organization for Security and Co-operation in Europe \\
\hline PSC & Political and Security Committee \\
\hline $\mathrm{R} \& \mathrm{D}$ & Research and Development \\
\hline RANPEA & $\begin{array}{l}\text { Russian Presidential Academy of National Economy and Public } \\
\text { Administration }\end{array}$ \\
\hline RELEX & Foreign Relations Counsellors Working Party \\
\hline QMV & Qualified Majority vote \\
\hline $\mathrm{SCO}$ & Shanghai Cooperation Organization \\
\hline SIPRI & Stockholm International Peace Research Institute \\
\hline SPDC & State Peace and Development Council \\
\hline UK & United Kingdom \\
\hline $\mathrm{UN}$ & United Nations \\
\hline UNCTAD & United Nations Conference on Trade and Development \\
\hline UNGA & United Nations General Assembly \\
\hline UNSC & United Nations Security Council \\
\hline US & United States \\
\hline
\end{tabular}




\begin{tabular}{|c|c|}
\hline USD & United States Dollar \\
\hline USSR & Union of Soviet Socialist Republics \\
\hline VGTRK & All-Russia State Television and Radio Broadcasting Company \\
\hline WEF & World Economic Forum \\
\hline WTO & World Trade Organization \\
\hline
\end{tabular}




\section{Chapter 1: Introduction to Sanctions, Theory, Background, and Scope of the Project}

\subsection{Introduction and Research Question}

Diplomacy is at the heart of international relations, and it is an essential political activity enabling states to further foreign policy objectives. Diplomacy and statecraft are sometimes seen as the most important functions of international relations, where negotiations between states

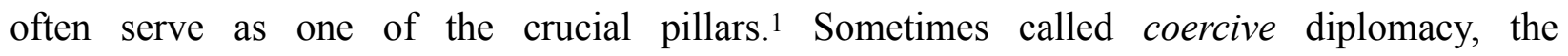
implementation of sanctions is one tool of diplomacy that states and diplomats can utilize, and can be used solitarily or in congruence with other means, such as military tools. ${ }^{2}$ Parallel to diplomacy's early beginnings, the practice of sanctions have been in known use since ancient Greece creating a foundational historical basis for the study of sanctions. With globalization, interdependencies, international institutions, and international law, sanctions have multiplied in the recent century, and more so in the recent decade. ${ }^{3}$ Although sanctions were previously

\footnotetext{
${ }^{1}$ Geoff Berridge, Diplomacy, Theory and Practice, 2015: 1, 101-102.

2 Cooper Drury, "Sanctions as Coercive Diplomacy: The U. S. President's Decision to Initiate Economic Sanctions," Political Research Quarterly, 54, no. 3 (2001);

Natalino Ronzitti et al., "Coercive Diplomacy, Sanctions and International Law," Istituto Affari Internazionali, 2016.

${ }^{3}$ Gary Clyde Hufbauer, Jeffrey J. Schott, Kimberley Ann Elliot, and Barbara Oegg, "Economic Sanctions Reconsidered," Peterson Institute for International Economics, 2007: 155.
} 
imposed as an extension of existing confrontation and/or military action, sanctions are now relied on as the main diplomatic tool in coercing a state to change its foreign policy - even as a substitute to military confrontation. ${ }^{4}$ In the study of diplomatic relations, it is often advantageous to include both the state that is applying a certain foreign policy and the state to which that foreign policy is being applied — as well as the 'secondary states' that react to this foreign policy. Similarly, in the analysis of sanctions, the observation of both the sender state (the state applying sanctions) and the target state (the state receiving sanctions) is key to obtaining a full picture of sanctions' effects. Further, the study of secondary states and secondary sanctions have recently become more important with globalization. Sanctions may incentivize the target state to turn to a third party state — known as a secondary state — with the objective of avoiding sanctions and not conceding to the aims of sender states. ${ }^{5}$ These reactions have motivated the creation of an additional type of sanctions known as secondary sanctions - also known as extraterritorial sanctions. ${ }^{6}$ Secondary sanctions are imposed against secondary states with the aim of preventing those third parties from engaging with the target state and to further isolate the target state from the possibilities of avoiding sanctions.

Many historic developments have affected the relations between Russia and Europe. After the brutish relations between the Soviet Union and the West, including western Europe, the post-Cold War era was an attempt to revive 'friendly' relations between Russia and Europe.?

\footnotetext{
${ }^{4}$ Richard Nephew, The Art of Sanctions: A View From the Field. The Art of Sanctions, New York: Columbia University Press, 2018: 1-10.

5 John J. Forrer, “Do Secondary Sanctions Work?” World Economic Forum, August 31, 2018.

6 Jonathan Masters, “What Are Economic Sanctions?” Council on Foreign Relations, August 12, 2019.

7 The Soviet Union, Russian Federation's predecessor, was also officially known as the Union of Soviet Socialist Republics (USSR).
} 
However, the collapse of the Soviet Union, the creation of 15 separate states including Russia and Ukraine, the expansion of the North Atlantic Treaty Organization (NATO), and various other developments have restructured the relations between Europe and Russia. Although EuropeanRussian relations run deep historic ties, both are young in their contemporary form. Considering the European Union's (EU) official foundation in 1993 and the Russian Federation's inception in 1991, both have recently formed important powers. Therefore, it is important to remember their historical ties, while also considering the contemporary situation in the application of international theories.

The Russian annexation of Crimea — as it was affirmed by United Nations (UN) Resolutions 68/262 and 73/263 — ignited a new era of sanctions and diplomatic tensions between the West and Russia. ${ }^{8}$ Russia's direct involvement in the annexation of Crimea and eastern Ukrainian territories of Donetsk and Luhansk, was responded with various sanctions imposed by Western states. The implementation of sanctions by the EU and US, and then later by Canada, Norway, Australia, Switzerland, New Zealand, Japan, and Iceland, led the process of pressuring Russia to change its foreign policy. These sanctions include traditional economic sanctions as well as sanctions against individual and corporate entities.

Sanctions did initially damage the Russian economy, and could also have disenchanted the Russian population and some elites. At the same time, sanctions have reunited large portions of the Russian population under patriotic and anti-Western sentiment, and have redirected Russia

8 United Nations General Assembly, “Territorial integrity of Ukraine,” Seventy-eight session, A/RES/68/262, April 1, 2014.

United Nations General Assembly, "Situation of human rights in the Autonomous Republic of Crimea and the city of Sevastopol, Ukraine," Seventy-third session, A/RES/73/263, January 21, 2019. 
to look elsewhere for economic opportunities. Most importantly, after continuously maintaining and even expanding these sanctions for more than six years, Russia has maintained its foreign policy and has not accommodated the aims of sanctions for them to be withdrawn. Therefore, this paper asks the following research question:

\section{Why have EU-imposed sanctions not been effective in shifting Russian}

\section{foreign policy to the aims of those sanctions thus far?}

"Thus far" was used to limit the time period to what has already occurred between 2014 and 2020, and leaves the possibility of sanctions becoming effective in the future. "Shifting Russian foreign policy" is an indicator for measuring effectiveness of sanctions. Since it can be argued that Russia did shift its foreign policy as a result of sanctions, "aims of sanctions" was added — leaving the possibility for Russian foreign policy to shift, but in a different direction.

\subsection{Scope of the Project}

Research was conducted from the inception of sanctions in 2014 to April 2020, providing almost a six year period of analysis. Sanctions against Russia are still ongoing as of April of 2020. This sanctions case primarily combines an analysis of the target state, sender states, their relationship, and external factors. All sender states in this particular case are acknowledged, however, due to the extensiveness of various sanctions policies, sender states, and their distinct relationships with the target state, this research primarily focuses on the EU. ${ }^{9}$ The EU is Russia's largest trading partner and contains a deep-rooted history and relationship, while also providing a

\footnotetext{
${ }^{9}$ Refer to Table 1.1 in Appendix A for a list of all sender states implementing sanctions against Russia, and the date of sanctions implementation.
} 
novel test for observing the effectiveness of the EU's relatively new sanctions policy. ${ }^{10}$ The EU also holds one of the most comprehensive sanctions lists out of all sender states, and has the greatest potential in increasing sanctions. For these reasons, only EU sanctions relating to shifting Russia's foreign policy are observed, including all types of sanctions (i.e., military, economic, individual, and diplomatic sanctions).

\subsection{Theoretical Framework and Hypothesis}

For theoretical purposes, this case study provides a unique opportunity to test Richard Nephew's and Makio Miyagawa's frameworks, and to expand them given the special case presented by the EU and Russia. Moreover, it attempts to broaden the limiting spectrum of evaluating sanctions as effective or ineffective. This case study will show how sanctions can go beyond the traditional definition of ineffectiveness and highlighting the potential for inadvertent effects, which can harm the sender states' interests. Finally, due to the contemporary nature of the case, most reviews completed provide an overview based on data at most four to five years, while this case study includes the most recent information to create the most comprehensive scope available to study this case. As for the hypothesis, this thesis states that:

\section{EU sanctions failed to change Russia's foreign policy towards the aims} of the sanctions. 11

\footnotetext{
10 United Nations Statistics Division, “Russian Federation: Exports,” United Nations, August 2019.

${ }^{11}$ Although this thesis is focused on evaluating the EU's sanction strategy and effectiveness, it is also important to mention that the failure to change Russia's foreign policy could be attributed to other sender states as well.
} 
This thesis hypothesizes that Nephew's and Miyagawa's sanctions framework will be able to explain why this occurred. The two frameworks complement each other, since each of the frameworks addresses different aspects of the failure - Nephew focusing on the nature of the sanctions and the sender states' strategy, while Miyagawa focuses on the nature of the target state and its capabilities. However, this thesis also hypothesizes that this unique case of sanctions can also help discover new attributes that could extend their frameworks.

Miyagawa outlined and examined 25 particular cases of sanctions in 1992, attributing success and failure to some. ${ }^{12}$ More importantly, Miyagawa's focus on numerous previous sanctions imposed against the Soviet Union provides analysis of sanctions effectiveness specific to Russia, and provides circumstances that usually dictate effectiveness that are reflective of both the target and sender states. ${ }^{13}$ His conclusion in determining whether or not the West's sanctioning of 'strategic goods' was successful is undetermined due to the fall of the Soviet Union during the time of publication. Although many saw sanctions shift from the West-Soviet Union paradigm and predicted it to remain sanction-less after the dissolution of the Soviet Union, the modern sphere of West-Russian relations suggest that sanctioning has returned. Therefore, it would be beneficial to observe Miyagawa's interpretation of previous occurrences and conclusions to see if there are any patterns or trends that could explain this particular case.

From his sanctions review, Miyagawa concludes with the following framework of conditions that enable sanctions to be effective being reflective of both sender and target states: a) dependence on trade, b) size of the economy — by the Gross National Product (GNP), c) trade

12 Makio Miyagawa, Do Economic Sanctions Work? Macmillan Press, 1992: 10-13.

13 Miyagawa, 24-28.

Demyan Plakhov 
partners, d) availability of substitutes, e) foreign exchange reserves, f) monitoring — via blockades, and g) economic system. ${ }^{14}$ Moreover, Miyagawa's explanation of how the target state may initiate defensive measures prior to sanctions, and/or harden its stance in light of imposed sanctions, will also help explain the effectiveness of the sanctions reviewed in this paper. ${ }^{15}$

Nephew's recent publication The Art of Sanctions (2018) provides a contemporary theory of sanctions strategy. Nephew's analysis of the US successful sanction campaign against Iran from 1996 to 2015 concluded that, after consistent pressure, Iran entered into negotiations with the US over its nuclear policy, changing its foreign policy, prompting the withdrawal of sanctions. In a recent interview, Daniel Drezner also agreed that Iranian sanctions represent a successful case, arguing that Iran's turn to the negotiating table was a change in its foreign policy. ${ }^{16}$ As a result, from this recent case, Nephew argues that the most effective process is to develop sanctions strategies by escalating pain and diminishing resolve, and then introducing diplomatic negotiations. This example shows that it is crucial to evaluate a sender's application of pain to achieve a defined objective, and the readiness of target states to withstand those sanctions in order to keep pursuing its agenda. For instance, sanctions by post-colonial African nations, a UN arms embargo, a UNGA-delivered oil embargo, and the West's later sanctions

\footnotetext{
${ }^{14}$ For Miyagawa, a target state has better chances of avoiding sanctions and/or diminishing their effectiveness if: a) the target state has lower dependence on foreign trade and able to self-sustain, $b$ ) the target state has a large economy (measured by GNI), c) the target state has trade with specific trade partners outside of sender states' sanctions, d) the target state has access to securing alternative foreign sources of supply (e.g. secondary states), e) the target state has. large foreign exchange reserves, f) the target state's situation creates a lack of possibility in the sender state monitoring/ensuring sanctions (e.g. blockades), and g) the target state's economic system is largely under government control and not a free enterprise system; Miyagawa, 24-28.

15 Miyagawa, 84-88.

16 Jorge Luis Perez Valery, and Sean Rameswaram, "Do sanctions work?" Today, Explained, VOX (Podcast), August 19, 2019.
} 
against South Africa that led to the dismantlement of the apartheid regime is a great example of effective sanctions. ${ }^{17}$ At the same time, comparing South Africa to contemporary Russia would not be the same. Russia has a great influence over international affairs, including the UNSC, its well-developed relations from the Soviet era, and its regional influence through bilateral relations and regional organizations. It also holds a substantial number of nuclear weapons, and conventional military. Russia is also an important international economic actor, especially in terms of natural resources - for which the EU is dependent on. Its projection of power and selfsustainability in various aspects gives it superior advantage over 1980s South Africa in dealing with sanctions. Thus, it is crucial for this research to evaluate the West's application of pain and its defined objective, and Russia's capacity to withstand that pain in order to pursue its current foreign policy.

\subsection{Literature Review of Sanctions and its Evolution}

Pericles' Megarian decree was a clear set of economic sanctions levied due to the kidnapping of three Aspasian women. ${ }^{18}$ Already, this early example illustrated by Thucydides and Aristophanes - in The Peloponnesian War and The Acharnians, respectively — shows the early disagreement in determining the significance of sanctions. In the post-First World War era, sanctions were beginning to substitute more hostile means of international relations. ${ }^{19}$ Prior to 1940s, sanctions were used in conjunction with hostile and military means, but sanctions were

\footnotetext{
${ }^{17}$ Fen Osler Hampson, “South African Apartheid,” Master of Persuasion, Toronto: Signal (2018): 196-250.

${ }^{18}$ Hufbauer, 9.

${ }^{19}$ Ibid, 10.

Demyan Plakhov
} 
beginning to be utilized more as 'stand-alone' policy. The establishment of the UN gave way to new large-scale multilateral sanction-authorizations, building on those attempted by the previous League of Nations. With increasing globalization and economic interdependence, sanctions became more utilized, experiencing a sudden boom in the 1990s. It is also clear that with this shift, Western powers — including the US and major European powers — also began to utilize sanctions more than any other state. ${ }^{20}$

Looking at the beginning of the last century, states would usually impose an embargo as a sanctions policy. ${ }^{21}$ Sanctions evolved in the 1990 s to become targeted or smart sanctions, which began to use more targeted and efficient methods such as travel bans and financial restrictions to target those responsible for policy decisions and those with influence over changing policy. ${ }^{22}$ This evolution came about as there was increased awareness of their devastating humanitarian impacts, and the lack of damage to the 'bad actors' who are responsible for the imposition of those sanctions. ${ }^{23}$ The next evolution of sanctions created secondary sanctions. In a more globalized environment, targeted states and entities could more easily avoid sanctions or economic damages by utilizing other sources or countries. Therefore, threatening the target state alone has now left major gaps in sanctions policies and necessitated the need for secondary

\footnotetext{
20 Hufbauer, 20-33.

21 John Smith and Kieran Beer, Sanctions with John Smith, Financial Crime Matters (Podcast), April 15, 2019.

22 Smith, Sanctions with John Smith, Financial Crime Matters, 2019;

State Secretariat for Economic Affairs SECO, "Smart sanctions - targeted sanctions," Swiss Confederation, March 24, 2017.

${ }^{23}$ Majid Khadduri and Hugh Kennedy, “Iraq: The UN Embargo and Oil-for-Food Program,” In Encyclopcedia Britannica, May 9, 2020.
} 
sanctions in order to threaten or punish secondary states for cooperating or engaging with the target state. However, these sanctions have been less investigated and have uncertain results.

The UN is a major international establishment for sanctions as it brings most, if not all states, together to produce an agreed international interpretation of sanctions and its use - given that member states agree to both the Charter of the UN and the Rome Statute governing the International Court of Justice (ICJ). In the UN Charter, Chapter VII outlines the UN Security Council's (UNSC) powers in determining situations requiring UN action, including UN-imposed sanctions. ${ }^{24}$ Under Article 41 of the same chapter, the UN defines sanctions as "measures not involving the use of armed force [... which] may include complete or partial interruption of economic relations and of rail, sea, air, postal, telegraphic, radio, and other means of communication, and the severance of diplomatic relations". ${ }^{25}$ As per Article 39 of the UN Charter, the UNSC can decide to implement sanctions when it determines that there is a threat to peace, breach of peace, or act of aggression. ${ }^{26}$ It is a definition that includes both economic and diplomatic measures, but also sets out an ambiguous definition allowing the UNSC flexibility in its decisions. However, at the same time, the UN Charter later outlines an almost paradoxical motivation in preserving "stability and well-being [...] necessary for peaceful and friendly relations among nations" under Chapter IX International Economic and Social Cooperation. ${ }^{27}$ This indicates that under the UN auspices, it is possible to have the intent to seek friendly

\footnotetext{
24 United Nations, "Chapter VII: Action with Respect to Threats to the Peace, Breaches of the Peace, and Acts of Aggression," Charter of the United Nations, October 24, 1945: 27.

${ }^{25}$ Ibid, 28.

26 Ibid, $27-28$.

${ }^{27}$ United Nations. "Chapter IX: International Economic and Social Co-operation," Charter of the United Nations. October 24, 1945: 38-40.
} 
economic and diplomatic relations, but also reserve the right to sanctions measures if there is a threat to peace. Moreover, the UNSC' subsidiary organ under the title of the Sanctions Committee further clarifies that UN's sanctions do hold a punitive aim and are applied with "ever-increasing cognizance of the rights of those targeted" providing de-listing measures. ${ }^{28}$

Since 1966, the UNSC has imposed 30 sanctions regimes under Article 41 throughout its lifetime, with measures ranging from "comprehensive economic and trade sanctions to more targeted measures such as arms embargoes, travel bans, and financial or commodity restrictions". ${ }^{29}$ Margaret Doxey's examination of UN-imposed sanctions cases argues that the UNSC's sanctions regimes have had a diverse record of effectiveness due to a major political issue, concluding that UN sanctions will always depend on the political will of the permanent members of the UNSC. 30 Even with these conclusions, Doxey still supports multilateral sanctions as they increase the probability of sanction effectiveness. ${ }^{31}$

Many factors vary from case to case including the states involved, the objectives of both sender and target states, and international law and treaties of the time. Consequently, effectiveness of sanctions vary from situation to situation, and in turn, evaluations of sanctions change - leading some to suggest that the literature that first claimed that sanctions did not "work at all," later shifted to "working sometimes". With regards to sanctions literature at large,

\footnotetext{
28 United Nations, “Sanctions,” United Nations Security Council, 2020.

29 United Nations, "Sanctions," United Nations Security Council, 2020; Margaret Doxey, "United Nations Sanctions," International Sanctions in Contemporary Perspective, Palgrave Macmillan, 1987: 32-52.

30 UN Permanent Members (in alphabetical order): China, France, Russia, UK and US.

31 Doxey, "The Impact of Sanctions," International Sanctions in Contemporary Perspective, Palgrave Macmillan, 1987: 115 .
} 
scholars suggest that sanctions usually do not work in most cases. ${ }^{32}$ Using various approaches and models of statistics, sanctions literature is heavily debated and highly interpretive of most sanction cases due to the variance in definitions, frameworks, and the inability to distinctively point out the true objectives of sanctions and their contribution to policy. The literature provides varying definitions of sanctions, depending on the objective in studying sanctions and their effectiveness. Sanctions are usually focused on the various forms that one state (sender state) will implement limitations on bilateral relations with another state (target state), in order to achieve a change in policy behaviour of the target state, that could include economic, diplomatic, military, and individual restrictions. ${ }^{33}$ However, additional literature indicates that sanctions sometimes go further by aiming to deter the target state from carrying out further particular foreign policy decisions, including the escalation of its current policy. ${ }^{34}$ At the same time, it is often difficult to determine what future foreign policy was deterred as a result of sanctions. In other instances, some sanctions literature suggests that sanctions' effectiveness should also include other aspects, such as the degree of their contribution to policy change. Likewise, sanctions' effectiveness can

\footnotetext{
32 Most famously indicated by Johan Galtung (1967), Peter Wallensteen (1968), Karin Knorr (1977), Robert Pape (1997), Clifton Morgan and Valerie Schwebach (1997), and Daniel Drezner (1999).

33 Susanne Oxenstierna and Per Olsson, "The Economic Sanctions Against Russia: Impact and Prospects of Success," FOI: Swedish Defence Research Agency: September, 2015.

34 Nicu Popescu, "Sanctions and Russia: Lessons from the Cold War," European Union Institute for Security Studies 10 (2015): 4;

Erica Moret, Thomas Biersteker, Francesco Giumelli, Clara Portela, et al., The New Deterrent? International Sanctions Against Russia over the Ukraine Crisis: Impacts, Costs and Further Action, The Graduate Institute of Geneva and the Geneva International Sanctions Network, October 12, 2016;

Wan Wang, "Impact of Western Sanctions on Russia in the Ukraine Crisis," Journal of Politics and Law 8, no. 2 (2015): 1-6;

John Mearsheimer, "Why the Ukraine Crisis Is the West's Fault: The Liberal Delusions That Provoked Putin," Foreign Affairs 93 (2014);

Elizabeth Pond and Hans Kundnani, “Germany’s Real Role in the Ukraine Crisis,” Foreign Affairs 94 (2015).
} 
be measured by the sender states unofficial objectives, such as internal political motives or for the purposes of managing public affairs.

Various terms suggested in sanctions literature further confuse the subject of sanctions. For instance, Cooper Drury uses "forms of negative economic pressure" that coerce the target state, rather than the precise definition of reducing economic relations. ${ }^{35}$ For Drury, economic pressure could mean a variety of methods in creating pressure without the reduction of economic relations, such as tariffs, denying the rescheduling or deferring of loans, and even travel bans. ${ }^{36}$ Others use the term pain to suggest the same type of economic pressure. More specifically, the literature still struggles in defining sanction effectiveness in a universal manner. For some, effective sanctions mean the effective implementation of pain or pressure upon the target state, and for some it involves all aspects of sanctions including the original aim of sanctions whether it was to respond to the international community, domestic outcry, key government stakeholders, or to support a particular foreign policy already in place. For Drury, to determine the effectiveness of sanctions, one must figure out what the sender state's real objectives are, since some sanctions that are seen as ineffective or having little "economic bite" might be actually effective since the sender state only intended on quelling domestic outcry. This is a difficult proposition since the process of deciphering the sender state's real objectives — besides those that are made official — are speculative and subjective, which leads to further disagreement. Some interpretations of sanction cases speculate objectives such as preventing the

\footnotetext{
35 Cooper A. Drury, "Evaluating Sanction Effectiveness," Economic sanctions and presidential decisions: models of political rationality, Palgrave Macmillan, 2005: 14.

36 Drury, 12-14.
} 
target state from expansionism, militarism, or nuclear options. ${ }^{37}$ This again becomes difficult to indicate with certainty since these objectives are not always expressed officially by the sender states — and are assumed — while it is also speculative to determine whether or not the target state was prevented from any further action. Moreover, Robert Pape and Daniel Drezner's disagreement further illustrates this complication, with Pape arguing that economic goals should not be included and Drezner arguing that they are naturally included since political and economic goals are usually blurred. ${ }^{38}$

Since 1985, David Baldwin and other scholars have suggested that sanctions can be as effective as military force, and is a safer and cheaper foreign policy option. ${ }^{39}$ However, it is also important to remember that literature prior to 1985 largely assumed economic sanctions as economic issues, rather than foreign policy tools. ${ }^{40}$ In the foreign policy toolbox, sanctions are part of hard power projection, which could explain why it was usually utilized in conjunction with military options — as opposed to sharp power, soft power, and smart power. ${ }^{41}$ Further, the

\footnotetext{
37 Joy Gordon, “A Peaceful, Silent, Deadly Remedy: The Ethics of Economic Sanctions,” Ethics \& International Affairs 13 (1999): 123-4, 127, 133, 138;

Jane E. Holl et al, Preventing Deadly Conflict: Final Report, Carnegie Corporation of New York, 1997;

Nicholas L Miller, “The Secret Success of Nonproliferation Sanctions," International Organization 68, no. 4 (2014): 913-944;

Richard H. Speier, Brian G. Chow, and S. Rae Starr, Nonproliferation Sanctions, RAND, 2001;

Christopher Daase, and Oliver Meier, Arms control in the 21st century between coercion and cooperation, Routledge Global Security Studies, 2013.

38 Drury, "Sanctions as Coercive Diplomacy: The U. S. President's Decision to Initiate Economic Sanctions," Political Research Quarterly, 54, no. 3 (2001): 15-16.

39 David Allen Baldwin, Economic Statecraft, Princeton University Press, 1985.

40 Drury, 2-3.

41 The three terms are defined as follows: a) sharp power as manipulative technique designed to influence a state through information or mass media, b) soft power as a diplomatic technique to attract or co-opt a state, and c) smart power as the technique combining soft and hard powers;

Christopher Walker, “What Is 'Sharp Power'?” Journal of Democracy 29, no. 3 (2018);

Joseph Nye, Bound to Lead: The Changing Nature of American Power, New York: Basic Books (1990);

Joseph Nye, "Get Smart: Combining Hard and Soft Power," Foreign Affairs, August, 2019.
} 
literature has extensively reviewed the effects of internationally-supported or multilaterallyauthorized sanctions, where most have agreed that these options assist legitimacy and efficacy, while others remain with reservations..$^{42}$ Hufbauer and other scholars also concluded in 2007 that in reviewing most 20th century sanction cases, more sender states and/or international cooperation does not necessarily guarantee success. ${ }^{43}$ In fact, it could dilute the objectives of sanctions and negotiations due to more states invoking sanctions, and empirical evidence suggested that sanction effectiveness was hindered with more sender states and by prolonging the duration of sanctions.

Sanctions literature has pointed to many factors and conditions that may lead to effective or ineffective sanctions policy. Predominantly the literature claims that sanctions are effective when accurately targeting ruling elites, and if sanctions were to be effective they should work as a threat or within approximately 5 years. ${ }^{44}$ Hufbauer's Economic Sanctions Reconsidered by provides an in-depth and sweeping analysis of sanctions that also recommends to examine not only the extent of the policy result or change, but to also see the contribution made by those sanctions. Consequently, this creates a more comprehensive analysis but complicates the analysis

42 Lisa Martin, Coercive Cooperation: Explaining Multilateral Economic Sanctions, Princeton University Press, 1992;

Hufbauer, 2007;

See Drezner for reservations: Drezner, Daniel W. The Sanctions Paradox: Economic Statecraft and International Relations. Cambridge University Press, 1999.

${ }^{43}$ Hufbauer.

${ }^{44}$ Hufbauer, 171;

Sean M. Bolks, and Dina Al-Sowayel, "How Long Do Economic Sanctions Last? Examining the Sanctioning Process through Duration," Political Research Quarterly 53, no. 2 (2000);

Han Dorussen, and Jongryn Mo, "Ending Economic Sanctions: Audience Costs and Rent-Seeking as Commitment Strategies," Journal of Conflict Resolution 45, no. 4 (2001);

Fiona McGillivray, and Allan C. Stam, "Political Institutions, Coercive Diplomacy, and the Duration of Economic Sanctions," The Journal of Conflict Resolution 48, no. 2 (2004): 154-72. 
further due to the level of subjectivity and uncertainty in determining both variables. Notwithstanding this complication, this crucial point of analysis considers other factors that could enhance or inhibit sanction effectiveness.

The use of carrot and stick, or smart power, is also largely positively acclaimed in sanctions literature advocating for both positive and negative sanctions to be utilized - positive being economic incentives, and negative being sanctions. ${ }^{45}$ This approach was determined as successful in the West and East Germany cases studied by Newman in 2000, while Davidson and Shambaugh went so far as to conclude that positive sanctions are more effective than negative. 46 Robert Dahl advocated for positive sanctions by placing it in the same power paradigm as negative sanctions, and proposed that positive sanctions could "be made to operate" while negative sanctions could not. ${ }^{47} \mathrm{He}$ noted that a sender state could implement the same opportunity cost by giving an imaginary $\$ 100$ for compliance or to threaten with a $\$ 100$ penalty for failure to comply. The costs of noncompliance are the same, Dahl argued, but incentivizing could be seen as more favourable to a target state. ${ }^{48}$

Nevertheless, the use of positive sanctions against opponents should be done with caution since opponents can use this strategy to gain an advantage and betray the agreement, or exemplify weakness of the sender state to the international community, while letting the target

\footnotetext{
45 Drury, 7-9.

46 Jason Davidson and George Shambaugh, "Chapter 3: Who's Afraid of Economic Incentives? The EfficacyExternality Tradeoff," Sanctions as Economic Statecraft, Palgrave Macmillan, 2000.

${ }^{47}$ Han Dorussen, "Mixing Carrots with Sticks: Evaluating the Effectiveness of Positive Incentives," Journal of Peace Research 38, no. 2 (2001).

48 Baldwin, David Allen. “The Power of Positive Sanctions.” World Politics 24, no. 1 (1971): 2. 
state keep its foreign policy. ${ }^{49}$ In doing so, it is important to keep in mind the costs associated with implementing incentives to ensure that the target state is not cheating. Thus, the literature suggests that in creating a sanctions strategy, negative sanctions ought to be placed to show disenchantment, with the negotiation of positive sanctions as means of incentivizing the opponent and to compliment negative sanctions. Additionally, Hufbauer and other studies also claim that the most successful sanction types are a combination of financial, export, and import sanctions as well as diplomatic and military pressures — as opposed to using just one or a few of these options. ${ }^{50}$ Drezner, on the other hand, argues that sanctions are most effective when they are not used, and only used as a threat, with a clear quid pro quo that utilizes a well-prepared and substantial threat that would be unnecessary and enormously damaging for the target. ${ }^{51}$ Director of the Office of Foreign Assets Control (OFAC) John Smith, claims that sanctions are most effective when they are applied multilaterally with a clear objective and are not overused by the sender state — because it is harder to get multilateral support. 52

Sanctions literature largely points to the ineffectiveness of sanctions in terms of their overall success rate, which may question the reason why states still utilize this tool and why

\footnotetext{
49 Drury, 9-10.

50 Hufbauer;

George A. Lopez and David Cortright, “The Key to a 'Smart' Sanctions Strategy,” Die Friedens-Warte 72, no. 4 (1997): 329;

United States Government Accountability Office, "Economic Sanctions: Agencies Assess Impacts on Targets, and Studies Suggest Several Factors Contribute to Sanctions' Effectiveness," Report to Congressional Requesters GAO-20-145 (October 2019): 19;

Elizabeth S. Rogers, "Using Economic Sanctions to Prevent Deadly Conflict," Belfer Center for Science and International Affairs, Harvard Kennedy School, Prepared for the Carnegie Commission on Prevent Deadly Conflict (May 1996).

51 Jorge Luis Perez Valery, and Sean Rameswaram, “Do sanctions work?” Today, Explained, VOX (Podcast), August $19,2019$.

52 Smith, Sanctions with John Smith, Financial Crime Matters, 2019.
} 
sanctions have been utilized more often recently. Nonetheless, the disagreement in literature and the inability to decisively explain sanctions' ineffectiveness could be a reason for states to continue the practice of administering sanctions, given that in some cases, sanctions have been found to be effective. The sanctions literature, including Miyagawa, Hufbauer, Drezner, Drury, provides an in-depth analysis of quantitative and qualitative research, debated definitions, and an indefinite answer about the effectiveness of sanctions. What is agreed in the literature is that sanctions work in some cases and they do not in others, that they are an effect produced by a cause of the target state, and they have many variables that contribute to their capacity to be effective. Studying these conditions, and possible frameworks for sanctions strategy, will allow to create an accurate assessment of the effectiveness of current sanctions imposed against Russia, an explanation for why they have not been effective thus far, and what strategy can be utilized to convince Russia to shift its foreign policy towards the aims of the sanctions. The literature assisted in developing definitions of sanctions, sender state, target state, and third nations, for the purposes of this research. In addition, it also enabled to analyze the different perspectives of when and why sanctions are implemented, and the definition of determining the effectiveness of sanctions.

Given the complications of determining sanctions' effectiveness, and in order to avoid speculative frameworks, this research defines sanction effectiveness simply as:

\section{When the target state changes its policy to reflect the aims of sender} state(s) in response to sanctions implemented by the sender state(s). 
For this case, EU's sanctions implemented against Russia would be considered effective if Russia changed its foreign policy to accommodate EU's stated sanctions' objectives.

In the contemporary case, the literature has attempted to answer the effectiveness of sanctions imposed on Russia since 2014. There are several indications that Russia has been negatively affected by sanctions, due to international isolation, elite factorization, economic damage, and spurred some internal movements. ${ }^{53}$ But Russia has still not changed its foreign policy to accommodate the removal of sanctions, and has seemingly withstood economic pressure. Russia has even gone as far as applying counter-sanctions and asymmetrical responses in its foreign policy towards sender states. ${ }^{54}$ Additionally, sanctions have been used by Russia domestically to promote anti-Western propaganda and increased public support for the current Russian government to oppose the West. ${ }^{55}$ The Russian government has been able to use various means to control the public sentiment in supporting its policy, including the media, culture, political pressure, and political oppression. On the other hand, the EU has utilized sanctions against at least 34 states. Clara Portela's 2010 evaluation of the EU's sanctions policy produced interesting results after examining the EU's sanctions against Moldova (Transnistria), Belarus, Myanmar (Burma), Uzbekistan, Nigeria, Indonesia, Kosovo, Democratic Republic of Congo, Sudan, Ethiopia, and Eritrea. Portela's findings concluded that EU's “sanctions are generally ineffective tools for accomplishing the objectives they aim for," due to various factors including:

\footnotetext{
53 Konstantin K. Khudoley, "Russia’s foreign policy amid current international tensions," Teorija in Praksa 53, no. 2 (2016): 398.

54 Emma Gilligan, "Smart sanctions against Russia: human rights, Magnitsky and the Ukrainian crisis," Demokratizatsiya: The Journal of Post-Soviet Democratization 24, no. 2 (2016): 257-277.

55 Khudoley, "Russia’s foreign policy amid current international tensions," 404.
} 
the changing of objectives during the sanctions period, inconsistencies created by EU member states' behaviour in the EU decision-making process, initiating minimal sanctions with slow momentum in the increase of sanctions' pressure, preoccupation with avoiding indiscriminate effects, EU member states' disagreement on sanctions' measures, the continuation of restricted actions under a blackmarket, the use of unilateral sanctions rather than multilateral, target states being able to find alternative suppliers (particularly China and Russia), appeasement, and the absence of free media and/or flawed democracy in the target state. ${ }^{56}$ Further, even when EU sanctions rarely succeed, they only contribute to a broader effort — as in Nigeria and Indonesia.

\subsection{Methodology}

With a basis in an empirical political approach, this paper focuses on an objective observation of the case to better explain the phenomenon. ${ }^{57}$ This paper tests some of the most applicable contemporary sanctions effectiveness theory frameworks. ${ }^{58}$ This case study utilizes triangulation through theory, methods, and sources. ${ }^{59}$ Through theory triangulation, this case study tests more than one sanctions' theory to interpret the data; one theory based on the sender state and the other on the target state. With method triangulation, this case study utilizes

\footnotetext{
56 Clara Portela, European Union Sanctions and Foreign Policy: When and Why do they work? Routledge Advances in European Politics, 2010: 59-101.

${ }^{57}$ A normative approach would focus on reviewing "what ought to be" and more prescriptive methods.

58 These applicable theory frameworks are by Nephew and Miyagawa, as mentioned previously.

59 Triangulation became a social science tool in the 1970s when Norman Denzin identified four basic types of triangulation "(1) data triangulation: the use of multiple data sources in a single study; (2) investigator triangulation: the use of multiple investigators/researchers to study a particular phenomenon; (3) theory triangulation: the use of multiple perspectives to interpret the results of a study; and (4) methodological triangulation: the use of multiple methods to conduct a study";

See more from United Nations AIDS, An Introduction to Triangulation, UNAIDS Monitoring and Evaluation Fundamentals, 2010.
} 
qualitative methods to explain the phenomenon reinforced with quantitative data. Using data triangulation, this case study incorporates empirical evidence gathered from first party sources such as public statements made by Russia and the EU, combined with news articles, and databases presented by third party institutions.

Nephew and Miyagawa's theories provide a meaningful test of various variables from both perspectives of the dispute, and portray a 'high-level' examination of the issue. The qualitative data gathered through publicly-accessible interviews, statements, and reports help make meaning of the circumstances and perspectives presented by each position in the dispute, while quantitative analysis assisted with reinforcing these explanations and the situation caused by the dispute using numerical data gathered from various sources including the World Bank, IMF, UN, Central Bank of Russia, and others. The use of public statements by states' leaders are essential in understanding the official foreign policy positions, while news articles help with verifying that information and provide a chance to rectify media biases. On the other hand, data collected by third parties establishes a long-term examination of the situation and considers longterm trends. As per the original purpose of triangulation, it is critical in corroborating evidence and observing various perspectives in developing a comprehensive understanding of the phenomenon. ${ }^{60}$

${ }^{60}$ Neil J. Salkind, “Triangulation,” In Encyclopedia of Research Design, 2010. 


\subsection{What Happened Here and Has It Happened Before?}

The short answer to this question is that most of what is discussed in this paper has happened before to some degree. The Crimean peninsula has been a contentious topic before, with it belonging to various ethnic and religious groups, suffering a series of invasions and external domination throughout its history, and a plethora of states attempting to control this peninsula for various reasons. Greek, Roman, Byzantine, Khanate, Ottoman, and Russian colonies habited the peninsula at various points in time; accordingly occupied by, among others, Christian minorities, Muslims, Roman Catholics, and eastern Orthodox religions.

The Russian Empire fought with the Ottoman Empire in the late 1700s with Catherine II gaining access to the peninsula and establishing Russia's navy presence in the Black Sea, which became a symbol of Russia's power and source of pride. Russia fought again nearly a century later in the Crimean War for three years, where it largely lost to an alliance comprising the Ottoman, French, and British Empires. The Treaty of Paris (1856), The Treaty of London (1871), The Treaty of Berlin (1878) and others all attempted to resolve the ongoing dispute between Russia and western European nations in the region. ${ }^{61}$ Consequently, it is clear to see Russia's connection to this peninsula and its historic opposition to western countries directly on this peninsula, as well as the complexities surrounding the Crimean peninsula. Crimea has been annexed by the Russian Empire, established as a Crimean Autonomous Socialist Soviet Republic under the Soviet Union, fallen under Nazi control in 1941, transferred by the Soviet leader Nikita Khrushchev from the Russian Soviet Federative Socialist Republic (RSFSR) to the Ukrainian

\footnotetext{
${ }^{61}$ David Wedgwood Benn, "Review: The Crimean War and its lessons for today," International Affairs 88, no. 2 (2012): 387-391.
} 
Soviet Socialist Republic (USSR) in 1954, and most recently was observed as part of Ukraine after the collapse of the Soviet Union given that post-Soviet republics kept their territory. ${ }^{62}$

The Ukraine-Russia relationship has also seen a historic flurry of occurrences leading to occasional unions, disputes, conflicts, and national identity crises. Both stemming from the Kievan Rus', the two have had a conflictual relationship, with Ukraine recurrently attempting to establish its own national identity and the Russian Empire consistently attempting to subdue the Ukrainian identity and incorporate its territory under Russia. ${ }^{63}$ This trend continued when Ukraine briefly enjoyed some independence after the Russian Revolution, up until 1922, when it was brought under Soviet control becoming one of the Union of Soviet Socialist Republics (USSR) and would not regain its independence until the 1991 collapse. ${ }^{64}$ Moreover, Russia's historic perspective of Ukraine can be seen through its language, as Ukraine stems from the word "borderland" or more directly translated as "on the edge of," implying that Ukraine is a territory on the edge of Russia's land. This also explains why Russians predominantly utilize "on Ukraine" rather than "in Ukraine" when discussing locations, since the former refers to a territory and the latter identifies a separate national identity for Ukraine. ${ }^{65}$

\footnotetext{
${ }^{62}$ M. S. Anderson, "The Great Powers and the Russian Annexation of the Crimea, 1783-4," The Slavonic and East European Review 37, no. 88 (December 1958): 17-41.

${ }^{63}$ Marvin Kalb, Imperial Gamble: Putin, Ukraine, and the New Cold War, Brookings Institution Press, September 21, 2015.

${ }^{64}$ Amanda Onion, Missy Sullivan, and Matt Mullen, "Ukraine declares its independence," This day in History January 26, 1918, November 5, 2009.

65 This distinction is similar to the English-relevant utilization of "on the Ukraine" rather than "in Ukraine." Russia's use of language to demean Ukrainian identity is used variously, including ethnic slurs. This is also evident even in the most recent interviews given by Russian President Putin in February of 2020, who insisted on the territorial pronunciation of Ukrainians (укра́инец) rather than the independent version (украи́нец), arguing that the name stems from the people who live on the edges of Russia;

TASS, and Vladimir Putin. 'We Are the Same People' - Putin Discusses Relations with Ukraine. Russia: RUPTLY, February 21, 2020.
} 
Its troubled relationship did not stop with Ukraine's independence in 1991 and Soviet disintegration. In fact, Russia utilized economic coercion on Ukraine in the aftermath of the collapse of USSR between 1993 and 1998 focusing on: a) transfer of all nuclear weapons to Russia, b) control over the Black Sea fleet, c) exclusive rights to Sevastopol (Crimea's main naval base holding the Black Sea Fleet), and d) control of both the energy industry and pipeline infrastructure. ${ }^{66}$ Immediately after the official establishment of contemporary Ukraine-Russia relations, the significant issues surrounded security, Black Sea fleet, Sevastopol, and energy trade. Although some compromises and agreements were made, these disputes remained, and they established the foundations of the contemporary ongoing dispute between Ukraine and Russia. ${ }^{67}$

Outside the Ukraine-Russia and Crimea challenges, this is also not the first time that the West and Russia have implemented sanctions against each other. Some have described the contemporary West-Russia disputes as the resurgence of the Cold War where the Western alliance (led by the US) faced against the Soviet Union for over four decades. The Cold War included various embargoes rather than just targeted financial restrictions and individual travel bans; it included nuclear threats and proxy conflicts in Korea, Vietnam, Central America, and Afghanistan. For some, the complicated West-Russia relationship stems from even earlier periods such as the Second World War (1939-45), the First World War (1914-18), the Crimean

\footnotetext{
66 Drezner, 198-208.

${ }^{67}$ Even after the compromises of the 1990s, both countries entered several disagreements over gas and Russia's rent of Sevastopol.
} 
War (1853-6), and even as far as the "Patriotic War of 1812".68 All exemplify periods of conflict, alliances, and brief moments of peace.

Sanctions between the West and Russia have been implemented countless times before. ${ }^{69}$ The UK implemented sanctions against Russia in 1918-20 and 1933.70 The USSR implemented sanctions against the US, UK, and France in 1948-9, Australia in 1954, Finland in 1958-9, and post-Soviet states in 1992-8, all for various reasons. ${ }^{71}$ After the Second World War, the US implemented an array of sanctions against the USSR to deny strategic materials and impair military potential (1948-94), to take down the Berlin Wall (1961-2), to liberalize Jewish emigration (1975-94), to liberalize treatment of dissidents (1978-80), to withdraw Soviet troops from Afghanistan (1980-1), to lift martial law in Poland, cancel pipeline projects with European nations, and impair economic and military potential (1981-2), and as retaliation for downing Korean airline Flight 007 (1983). ${ }^{72}$ US and the European Community (EC), officially unifying sanctions regimes for the first time, briefly tried to block the coup and restore Gorbachev's government in 1991 through sanctions. ${ }^{73}$ Based on this evidence, most Western attempts to change Russia's policy through sanctions achieved minimal results, moderate at most. ${ }^{74}$ In

68 The Patriotic War of 1812 is commonly used in Russia to reference the French invasion of Russia by Bonaparte Napoleon, while the Second World War is commonly referred to as the "Great Patriotic War" in Russia.

${ }^{69}$ Hufbauer, 20-33.

70 Miyagawa, 20.

${ }^{71}$ Miyagawa, 20-38;

Russia, the successor state of the Soviet Union, applied sanctions in at least 15 various cases since 1948, with varied results, which also included target states: former Yugoslavia, China, Albania, and Romania.

72 Miyagawa, 20-33.

${ }^{73}$ Ibid, 29;

The European Community (EC) was an economic organization formed by Belgium, Netherlands, Luxembourg, France, Italy, and West Germany in 1951, which led to the eventual creation of the European Union in 1993.

${ }^{74}$ Ibid, $75-87$. 
addition, it shows that Western sanctions became less effective throughout the 20th century, and that the few policy changes that were achieved were largely not due to sanctions. The previous cases also suggest that sanctions were least effective when attempting to change Russia's foreign policy, exhibited through sanctions related to Flight 007, Comecon, Afghanistan, martial law in Poland, and energy pipeline projects in Europe.

The sanctions case study examined here began with Russia's annexation of Crimea. ${ }^{75}$ In 2013, former Ukrainian President Viktor Yanukovich turned away from a potential association agreement with the EU under increasing economic pressure from Russia. ${ }^{76}$ In response, Ukrainians began a wide-spread movement, sparked in Kiev, also known as "Euromaidan". Yanukovich's supporters and pro-Russian movements clashed with the EU-oriented and Ukrainian nationalist movements — with state police adding to the violence. Civil unrest became wide-spread, and Russia reacted by assisting President Yanukovich to flee the country, leaving

\footnotetext{
75 Instead of "the reunification of Crimea," this paper operates on the assumption that Russia annexed Crimea since Russia carried out an administrative unilateral act of forceful acquisition of Ukraine's territory, which was then condemned by the international community as per United Nations General Assembly Resolution 68/262. Both the OSCE and UN have used "annexation" to describe this action by the Russian government; Office for Democratic Institutions and Human Rights, "Ukraine: Presidential Election 31 March and 21 April 2019," ODIHR Election Observation Mission Final Report, Organization for Security and Co-operation in Europe, November 20, 2019: 1;

UN News, "Political solution 'long overdue' to protect the children of eastern Ukraine," Based on reporting from UNICEF, December 2, 2019; Donald Rothwell, Stuart Kaye, Afshin Akhtarkhavari, and Ruth Davis, "6.6 Cession and Annexation," International Law: Cases and Materials with Australian Perspectives, Cambridge University Press, 2014;

Rainer Hofmann, “Annexation,” In Max Planck Encyclopedias of International Law, January 2020; United Nations General Assembly, "Territorial integrity of Ukraine," Seventy-eight session, A/RES/68/262, April 1, 2014.

${ }^{76}$ Naja Bentzen, “A UN peacekeeping mission in eastern Ukraine?” EPRS $\mid$ European Parliamentary Research Service, March 2018.
} 
pro-Western political groups in power. ${ }^{77}$ The new pro-Western political groups were not popular with the Russian-friendly eastern regions of Ukraine, and Russia used the opportunity to deploy unmarked troops to Crimea (south Ukraine) and Donbass (eastern Ukraine) in the aims of 'protecting' the Russian population from 'nationalists'. On March 16, 2014, an internationally unrecognized referendum was held where an overwhelming number of voters chose to become part of Russia rather than staying part of Ukraine. ${ }^{78}$ Two days later President Vladimir Putin signed Crimea and Sevastopol into law as Russia's newest provinces. ${ }^{79}$

As a result of Russia's actions in Ukraine, the EU (along with other sender states) strongly condemned the "unprovoked violation of Ukrainian sovereignty and territorial integrity"

\footnotetext{
77 In addressing decisions of countries it is important to address those decisions to the appropriate authorities responsible for those decisions on behalf of their nations. Although 'elected', key state decision-makers are at times not reflective of the nation they are representing, and/or enforce particular decisions which are not necessarily representative of the entire country or have overwhelming public approval. Therefore, this will serve as a disclaimer indicating that when addressing states by their name this paper will be addressing the key decision-makers responsible for government policy of their state. It is becoming particularly difficult to link Russia's leadership to its public, since the most recent Democracy Index conducted by the Economist Intelligence Unit indicates not only Russia's all-time low in its democratic standing - from 2006 to present - but also its rapid and consistent decline from a hybrid regime with a score of 5.02 to an authoritarian regime with a score of 2.94 (Economist, 2020). This is exemplified by Russia's elections, which are heavily restricted, unfair, and prevent political competition, as indicated by OSCE's international observers who noted that Russia presents a "choice without real competition [...] the legal framework restricts many fundamental freedoms [...] elections [in Russia] almost lose their purpose" (OSCE report, 2018). Therefore, making it more difficult to address the decisions made by the Russian government as a reflection of the Russian public in its entirety. With these considerations, it is better to distinguish the Russian government and its key decision-makers from the rest of the Russian public. Therefore, when referring to "Russia," this paper will be mostly addressing the Russian government and its decisions, and not necessarily the Russian public - unless stated otherwise. Correspondingly, by referring to "Russian interests" this paper will be mostly referring to the interests of the Russian government; Economist Intelligence Unit, "Daily Chart," EUI Democracy Index 2020, January 22, 2020; Nat Parry, and Thomas Rymer, "Russian presidential election well administered, but characterized by restrictions on fundamental freedoms, lack of genuine competition, international observers say," Office for Democratic Institutions and Human Rights, Organization for Security and Co-operation in Europe, March 19, 2018.

78 OSCE Chairmanship, "OSCE Chair says Crimean referendum in its current form is illegal and calls for alternative ways to address the Crimean issue," Organization for Security and Co-operation in Europe, March 11, 2014.

79 This is an oversimplified description of the events that happened between 2013 and 2014, and since these events are more detailed and nuanced, for further elaboration see:

David R. Marples, and Frederick V. Mills, Ukraine's Euromaidan: Analyses of a Civil Revolution, ibidem Press, April 1, 2015.
} 
and called for Russia to immediately withdraw its armed forces on March 6, 2014.80 On March

17, the EU implemented sanctions against Russia and continuously urged to Russia to use its influence over armed groups in eastern Ukraine to achieve peace. ${ }^{81}$ The EU continued to urge Russia relating other issues such as the downing of MH17 in Donetsk, and the flow of military support for separatist groups in Donbass. The first Minsk Agreement signed in September of 2014 largely failed to halt the conflict in Donbass. ${ }^{82}$ On February 12, 2015, leaders from Russia, Ukraine, France, and Germany came together to sign a renewed accord: Minsk II Agreement. This agreement similarly did not succeed in halting the conflict, but is largely used to carry out peace talks in Normandy Format (Russia, Ukraine, France, and Germany). ${ }^{83}$ On March 19, 2015, the EU agreed to link most of its sanctions to the complete implementation of the Minsk II Agreement. The agreement became central to both the conflict in Ukraine and for the EU sanctions policy towards Russia. ${ }^{84}$

\footnotetext{
80 This warning was given prior to the annexation:

European Union, “Country: Russia,” EU Sanctions Map, March 4, 2020.

${ }^{81}$ Council of the European Union. "Concerning restrictive measures in respect of actions undermining or threatening the territorial integrity, sovereignty and independence of Ukraine." Council Decision 2014/145/CFSP. Official Journal of the European Union. March 17, 2014;

The conflict in eastern Ukraine to date has put innocent civilians in danger, lowered living standards, damaged infrastructure and institutions. The conflict has resulted in over 13,000 deaths, at least 3.4 million in desperate need of humanitarian aid, and 1.5 million internally displaced persons (IDPs).

82 Economist, “What are the Minsk agreements?” Economist Explains, September 14, 2016.

${ }^{83}$ Bentzen, Naja. "Ukraine and the Minsk II agreement On a frozen path to peace?" EPRS | European Parliamentary Research Service, January 2016.

84 The EU's Foreign Affairs Council (FAC) outlined "the full implementation of the Minsk Agreement" as one of the main guiding principles in current EU-Russian relations;

European Union, “Country: Russia,” EU Sanctions Map, March 4, 2020;

Refer to Table 1.2 in Appendix A for the translated outline of Minsk II Agreement from Russian.
} 


\section{Chapter 2: Reviewing European Union's Sanctions Strategy}

\subsection{How and Why the EU Utilizes Sanctions}

In 2004, the Political and Security Committee (PSC) of the EU's Foreign Affairs Council first agreed on the EU's sanctioning basic principles by outlining their utilization, implementation, measurement, and impact management. ${ }^{1}$ What first began as a 2003 guideline, was subsequently updated four times, and inspired the EU Best Practices for the effective implementation of restrictive measures guideline. ${ }^{2}$ As the European Council notes, sanctions or as the EU usually refers to them as 'restrictive measures' — are "an essential tool of the EU's Common Foreign and Security Policy (CFSP) [ .. and] are used by the EU as part of an integrated and comprehensive policy approach, involving political dialogue, complementary efforts and the use of other instruments at its disposal". ${ }^{3}$ As per the European Council, by

\footnotetext{
${ }^{1}$ Council of the European Union, "Basic Principles on the Use of Restrictive Measures (Sanctions)," 10198/1/04 REV 1 PESC 450, June 7, 2004.

2 Council of the European Union, "Sanctions: how and when the EU adopts restrictive measures," Overview. March 6, 2020;

Council of the European Union, "Restrictive measures (Sanctions) - Update of the EU Best Practices for the effective implementation of restrictive measures," Foreign Relations Counsellors Working Party 8519/18, May 4, 2018 .

${ }^{3}$ Council of the European Union, "Sanctions: how and when the EU adopts restrictive measures," Overview. March $6,2020$.
} 
implementing sanctions, the EU's stated objective is to "bring about a change in the policy or conduct" of the target state to protect CFSP objectives. ${ }^{4}$ Since EU sanctions can target governments, groups, entities, and individuals, they are implemented with the objective of minimizing adverse consequences for those not responsible for policies or actions leading to sanctions, and complying with the international law especially with regards to human rights and fundamental freedoms.

The EU imposes sanctions as part of its CFSP to achieve four key objectives: a) to defend EU's values, fundamental interests, and security, b) to maintain peace, c) to promote democracy, rule of law, human rights and principles of international law, and/or d) to deter conflicts and bolster international security. Its basic principles even go so far as to suggest that the EU is prepared to use "coercive measures" in accordance with the UN Charter as a last resort, with no direct definition of coercive measures, leaving ambiguity about the variety of coercive measures that could include the threat of use of force. Currently, the EU maintains 44 sanctions regimes against 33 nations, with some originating internally on behalf of the EU (referred to as "EU autonomous sanctions") and the others supporting UN-imposed sanction regimes. ${ }^{5}$ The EU imposed sanctions for the first time in 1991 on Myanmar (Burma), condemning State Peace and Development Council's (SPDC) rejection of the 1990 elections results. The sanctions were

${ }^{4}$ Council of the European Union, "Sanctions: how and when the EU adopts restrictive measures," Overview. March $6,2020$.

5 European Union, EU Sanctions Map, May 13, 2020; Council of the European Union, "Different types of sanctions," Sanctions: how and when the EU adopts restrictive measures, June 6, 2019. 
maintained for 21 years. ${ }^{6}$ It is often hypothesized that because the EU lacks a joint military force, its sanctions policy is the bloc's most powerful foreign policy tool. ${ }^{7}$

With regards to how the EU enacts sanctions, the process begins with a CFSP Council proposal, which is delivered as a joint proposal by the High Representative and the Commission for a Council regulation. ${ }^{8}$ The joint proposal is then examined by the working party of Foreign Relations Counsellors Working Party (RELEX), and afterwards, forwarded to the Committee of Permanent Representatives (COREPER) and requires European Council consensus (unanimity) for adoption. The Council then informs the European Parliament of the adoption of the Council regulation, which is then a legal act that is binding to any person or entity within the EU. ${ }^{9}$ During the implementation, the European Commission verifies that the member states are complying with the regulations in a "proper and timely manner". ${ }^{10}$ Sanctions imposed on an 'autonomous basis' are then reviewed in its entirety every six months, and before extending sanctions for another six months, the European Council will review the restrictive measures, which allows it to amend, extend, or suspend the measures. ${ }^{11}$ The EU's guidelines, principles, and processes theoretically — allow for a well-thought out, methodological, flexible, and unified sanctions strategy.

\footnotetext{
6 Francesco Giumelli, "How EU sanctions work: A new narrative," Chaillot Papers no. 129, European Union: Institute for Security Studies, May 2013, 29.

7 Jonathan Masters, “What Are Economic Sanctions?” Council on Foreign Relations, August 12, 2019.

8 Council of the European Union, "Adoption and review procedure for EU sanctions," Sanctions: how and when the EU adopts restrictive measure, February 14, 2019.

${ }^{9}$ Ibid.

${ }^{10}$ Ibid.

${ }^{11}$ Ibid.
} 


\subsection{Type of EU Sanctions}

Sanctions aimed directly at Russia focus on seven sectoral restrictive measures "in view of Russia's actions destabilising the situation in Ukraine". ${ }^{12}$ In brief, the EU placed the following restrictions:

Arms trade: importing, exporting, or transporting arms and related materials from or to Russia are prohibited, as well as providing related technical or financial assistance..$^{13}$

Dual-use goods export: the prohibition of selling, supplying, transferring, or exporting any dual-use goods or technology for military use to Russia or any person, entity, or body in Russia. This includes any related technical or financial assistance. ${ }^{14}$

Financial measures: the prohibition of any new loans, credit, transactions, or business. Dealings with any listed person, entity or body. ${ }^{15}$

Satisfying claims: satisfying claims in connection with any contract or transaction affected by the sanctions regime are prohibited.

Other items: exporting, selling, supplying, or transferring equipment listed in Annex II of Council Regulation 833/2014 is subject to prior authorization by the competent authority of the exporting Member State - most of the products listed in Annex II target equipment used in the oil and gas sector.

Restrictions on services: prohibiting services necessary for Russian oil exploration and production in waters deeper than 150 metres, in the offshore area north of the Arctic Circle, and for projects that have the potential to produce oil from resources located in shale formations by way of hydraulic fracturing (it does not apply to exploration and production through shale formations to locate or extract oil from non-shale reservoirs) shall be prohibited.

These measures are often cited as EU's economic or sectoral sanctions. The EU's

financial measures largely target Russia's banking, finance, defence, and oil sector. It is also

\footnotetext{
12 European Union, “Country: Russia," EU Sanctions Map, March 4, 2020.

13 The EU's complete list is found in its "Common Military List of the European Union," last update on February 18, 2019:

Council of the European Union, "Equipment covered by Council Common Position 2008/944/CFSP defining common rules governing the control of exports of military technology and equipment," Notices from European Union Institutions, Bodies, Offices and Agencies, Official Journal of the European Union, March 12, 2019.

${ }^{14}$ Council of the European Union, "Equipment covered by Council Common Position 2008/944/CFSP defining common rules governing the control of exports of military technology and equipment," Notices from European Union Institutions, Bodies, Offices and Agencies, Official Journal of the European Union, March 12, 2019; European Union, "Country: Russia," EU Sanctions Map, March 4, 2020.

${ }^{15}$ List includes Sberbank, VTB Bank, Vnesheconombank (VEB), Rosneft, Transneft and Gazpromneft.
} 
crucial to highlight here that there are no EU sanctions or restrictions imposed on any agricultural trade. The EU did impose financial restrictions on Rosselkhozbank, which supports Russia's agricultural sector. However, Rosselkhozbank ensures availability of finances, credits, and banking, to support agribusiness development. ${ }^{16}$ As such, EU sanctions restrict this bank's availability to EU resources in order to finance the development of Russia's agribusiness, but does not directly prevent any Russian agricultural trade.

However, there is one more set of sanctions that need to be addressed as part of EU's sanctions imposed against Russia due to, "restrictive measures in respect of actions undermining or threatening the territorial integrity, sovereignty and independence of Ukraine". ${ }^{17}$ Correspondingly, the EU imposed the following sanctions against Crimea: ${ }^{18}$

Asset freezes: of all listed persons and entities, and prohibits any access to direct or indirect funds and assets. ${ }^{19}$

Travel restrictions: EU member states must enforce travel restrictions on listed persons.

Import and export ban: prohibits goods from Crimea and Sevastopol, and exporting restricted goods and technologies. ${ }^{20}$

Trade and investment restrictions: restrictions on trade and investment in certain economic sectors and infrastructure projects.

Prohibition of tourism assistance: prohibiting the supply of tourism services to Crimea or Sevastopol.

\footnotetext{
16 Rosselkhozbank, "Missiya," O banke, 2020;

Rosselkhozbank, "Strategiya AO 'Rosselkhozbank' do 2020 goda: Osnovnye polozheniya," Aktsianoernoye obshestvo 'Rossiyskiy Selskokhozyaystveniy bank,' April 2016.

17 European Union, “Country: Russia,” EU Sanctions Map, March 4, 2020.

18 Sanctions against Crimea are listed as against Ukraine, but this is due to the fact that the EU does not recognize Crimea as a territory of Russia.

19 European Union, “Country: Russia,” EU Sanctions Map, March 4, 2020.

${ }^{20}$ Council of the European Union, "EU restrictive measures in response to the crisis in Ukraine," Sanctions: how and when the EU adopts restrictive measures, March 13, 2020.
} 
The EU has placed asset freezes and travel bans on 175 people and 44 entities because of their actions in "undermining Ukraine's territorial integrity, sovereignty and independence". 2122 However, this category combines individual sanctions and sanctions against the Crimean peninsula - which is often talked about as separate measures. The reason why they are in one category is due to the fact that they were implemented with the same reasons and for similar objectives, which will be further elaborated in the next section (2.3).

Other sanctions and restrictions are worth mentioning as part of the EU's total package in response to Russia's annexation of Crimea and destabilization of Ukraine, including economic cooperation and diplomatic measures. With regards to economic cooperation, the EU requested the European Investment Bank (EIB) to suspend new financing operations in Russia, EU member states agreed to harmonize their stances within the European Bank for Reconstruction and Development (EBRD) Board of Directors to suspend new financing operations in Russia, and the EU suspended bilateral and regional cooperation programs with Russia. ${ }^{23}$ As for the diplomatic measures, EU member states agreed to not hold regular bilateral summits with Russia, while the EU suspended bilateral negotiations with Russia on visa matters and cancelled the EU-Russia summit in 2014. Instead of the planned G8 Sochi summit in 2014, a G7 meeting

\footnotetext{
21 The full list of sanctioned individuals is listed here:

Council of the European Union, "EU restrictive measures in response to the crisis in Ukraine," Sanctions: how and when the EU adopts restrictive measures, March 13, 2020;

Council of the European Union, "Concerning restrictive measures in respect of actions undermining or threatening the territorial integrity, sovereignty and independence of Ukraine," Council Decision 2014/145/CFSP, EUR-Lex Publications office, September 14, 2019.

22 The full list of sanctioned entities is listed here:

Council of the European Union, "Concerning restrictive measures in respect of actions undermining or threatening the territorial integrity, sovereignty and independence of Ukraine," Council Decision 2014/145/CFSP, EUR-Lex Publications office, September 14, 2019.

${ }^{23}$ Council of the European Union, "EU restrictive measures in response to the crisis in Ukraine," Sanctions: how and when the EU adopts restrictive measures, March 13, 2020.
} 
was conducted in Brussels and have continued in the form of the G7 - eliminating Russia from the group. ${ }^{24} \mathrm{EU}$ member states also suspended talks with Russia on the terms of Russia entering the Organization for Economic Co-operation and Development (OECD) and the International Energy Agency (IEA).

Overall, the EU has imposed a series of restrictive measures that have been extended until at least September 2020. The EU sanctions package has been comprehensive, diverse, and extremely targeted utilizing both diplomatic and economic measures, individual and sectoral restrictive measures, and measures against Russia and territories affected (Crimea, Sevastopol, Simferopol, Lugansk, and Donetsk). The EU's sanctions' lists have also been consistently updated based on evolving circumstances. ${ }^{25}$

\subsection{Sanctions Against Russia: List of Official Sanctions' Aims}

The EU implemented sanctions against the Russia Federation due to Russia's illegal annexation of Crimea, deliberate destabilization of a neighbouring sovereign country (Ukraine), and actions in undermining or threatening the territorial integrity, sovereignty and independence of Ukraine. ${ }^{26}$ Drawing from this and the EU's public statements, EU's sanctions are aiming to

\footnotetext{
${ }^{24}$ Council of the European Union, "EU restrictive measures in response to the crisis in Ukraine," Sanctions: how and when the EU adopts restrictive measures, March 13, 2020.

25 Council of the European Union, “Amending Decision 2014/145/CFSP concerning restrictive measures in respect of actions undermining or threatening the territorial integrity, sovereignty and independence of Ukraine," Council Decision (CFSP) 2017/1561, EUR-Lex Publications office, September 15, 2017;

The G7, or the Group of Seven, is an international intergovernmental economic organization consisting of Canada, France, Germany, Italy, Japan, UK and US - holding over 50\% of the global national net wealth, and nearly half of the global GDP — which organizes regular meetings between heads of states of those nations.

${ }^{26}$ Council of the European Union, "EU restrictive measures in response to the crisis in Ukraine," Sanctions: how and when the EU adopts restrictive measures, March 13, 2020;

European Union, "Country: Russia," EU Sanctions Map, March 4, 2020.
} 
achieve a change in Russia's foreign policy that recognizes the above reasons and retracts those actions that caused sanctions. Therefore, in a simplified form, the following are the EU's official objectives in changing Russia's foreign policy — those that would guarantee the removal of sanctions:

a) Return of Crimea to Ukraine from Russia;

b) Halt Russia's deliberate destabilization of Ukraine and undermining its territorial integrity, sovereignty and independence; and

c) Fully implement Russia's responsibilities of the Minsk II Agreement.

This leads to an important discussion about the distinction of EU sanctions packages and their objectives. At first, the 2014 wave of sanctions was a response to Russia's actions in Ukraine. But on March 19, 2015, the European Council clarified that economic, or sectoral, sanctions (including trade, and financial restrictions targeting specific sectors of the Russian economy) will be linked to Russia's implementation of the Minsk II Agreement. ${ }^{27}$ Although much of the media coverage showed this as the entire sanctions package being linked to the Minsk II Agreement, there was a key, albeit ambiguous and unclear, distinction made by the EU.28 The EU still links the individual sanctions (including asset freezes and travel bans) and sanctions against Crimea (including restrictions on trade, trade investment, and tourism) to "the illegal annexation of Crimea and Sevastopol by Russia" and the EU's commitment to "Ukraine's sovereignty and territorial integrity," and not to the Minsk II Agreement. ${ }^{29}$ Although the EU has not explicitly stated that returning Crimea is one of its sanctions' objectives, it has repeatedly claimed to

\footnotetext{
27 European Council, “External relations,” Meetings: European Council, 19-20 March 2015, May 2, 2018.

${ }^{28}$ Cynthia Kroet, "Merkel: EU will lift Russia sanctions when Minsk accords implemented," Politico, February 5, 2017.

${ }^{29}$ Council of the European Union, "Illegal annexation of Crimea and Sevastopol: EU extends sanctions by one year," Press releases, Press Office, June 20, 2019.
} 
support Ukraine's territorial integrity and UN Resolution 68/262, which would indicate that it does support Crimea as part of Ukraine. ${ }^{30}$ Therefore, it could be deduced that individual sanctions and sanctions against Crimea are linked to the return of the Crimean peninsula. By this logic, if Russia fully implements the Minsk II Agreement and keeps Crimea under its authority, the EU's individual and Crimean sanctions would remain. Therefore, effectiveness of sanctions can be split between the two distinctions with one being effective (Russian implementation of the Minsk II Agreement) and the other being ineffective (the return of Crimea). However, altogether, it would constitute partial effectiveness.

There is clearly a distinction between these sanctions packages (sectoral, individual, and Crimean) when considering the fact that the EU evaluates these three sanctions packages separately. ${ }^{31}$ The EU Council usually decides on extending 'economic', or sectoral sanctions every six months, once in July and once in December. ${ }^{32}$ While individual sanctions are voted on every March and September, and the third category of sanctions against Crimea and Sevastopol are evaluated every 12 months, usually occurring in June.33 The EU Council's decision on economic sanctions, every July and December, is based on an update by President Macron and Chancellor Merkel on the state of implementation of the Minsk II Agreement. ${ }^{34}$ Since the points

30 UNIAN, "EU calls on all UN member states to join sanctions against Russia," Politics, March 18, 2016.

${ }^{31}$ First sanctions package: economic or sectoral. Second sanctions package: individual sanctions. Third sanctions package: sanctions against Crimea.

${ }^{32}$ Council of the European Union, "Timeline - EU restrictive measures in response to the crisis in Ukraine," EU restrictive measures in response to the crisis in Ukraine, March 13, 2020.

${ }^{33}$ Council of the European Union, "Timeline - EU restrictive measures in response to the crisis in Ukraine," $E U$ restrictive measures in response to the crisis in Ukraine, March 13, 2020; Council of the European Union, "Illegal annexation of Crimea and Sevastopol: EU extends sanctions by one year," Press releases, Press Office, June 20, 2019.

${ }^{34}$ Council of the European Union, "Russia: EU prolongs economic sanctions by six months," Press releases. Press Office, December 19, 2019. 
of the agreement are still not fulfilled by Russia, the EU extends its sanctions to "target financial, energy and defence sectors". ${ }^{35}$ Once again, the distinction is not clear with respect to the aims of individual sanctions and sanctions against Crimea, since the EU consistently repeats that they are linked to "actions undermining or threatening the territorial integrity, sovereignty and independence of Ukraine" and "the illegal annexation of Crimea and Sevastopol," but without explicitly stating the goal of returning Crimea. ${ }^{36}$ This holds true throughout five years later, with a declaration made by the High Representative for Foreign Affairs and Security Policy on behalf of the EU on 17 March, 2019, stating that "the EU remains steadfast in its commitment to Ukraine's sovereignty and territorial integrity. The EU does not recognise and continues to condemn this violation of international law," when commenting on the reasons of continuing sanctions against Crimea in particular. ${ }^{37}$

On another note, the Council of the EU affirmed in April of 2014 that sanctions are not aimed as "punitive" measures, but are instead designed with the objective of "bring[ing] about a change in policy or activity by the target country". 38 These aims are, therefore, a reflection of the EU's reasons for implementing sanctions, targeting Russia's policies and activities, the means to conduct them and individuals responsible for them. ${ }^{39}$ Moreover, it is important to keep in mind that the imposition of sanctions is not an objective in itself for the EU, since it would be against

\footnotetext{
35 Council of the European Union, "Russia: EU prolongs economic sanctions by six months," Press releases, Press Office, December 19, 2019.

36 Council of the European Union, "EU extends sanctions over actions against Ukraine's territorial integrity until 15 March 2020," Press releases, Press Office, September 12, 2019.

37 Council of the European Union, "Illegal annexation of Crimea and Sevastopol: EU extends sanctions by one year,” Press releases, Press Office, June 20, 2019.

${ }^{38}$ Council of the European Union, "EU restrictive measures," Factsheet, Press Office, April 29, $2014: 1$.

39 Ibid.
} 
its economic and trade interests. Former President of the European Council Herman van Rompuy concurred with this fact when he stated in March 2014 that "sanctions are not a question of retaliation, they are a policy tool. Not a goal in themselves, but a means to an end". 40 Nevertheless, EU members have often refrained from indicating what their sanctions' goals are, nor has the EU indicated any other negotiable concessions or alternatives that would also permit the removal of sanctions. ${ }^{41}$ Rather, EU leaders indicated the need for "respecting territorial integrity", "rules-based international order", and other general items. EU member states have also publicly stated various messages and aims, including EU's general message as stated above. Some member states have messaged the need for sanctions, the need for Russia to take appropriate steps forward, and the aim of eliminating sanctions as soon as Russia takes appropriate steps towards fulfilling the EU's objectives. However, these appropriate steps are largely unclear and diverse.

For instance, Italian Prime Minister Giuseppe Conte indicated on July 4, 2019, that Rome was interested in "creat[ing] conditions for overcoming this state of relations between the EU and Russia, which is not good for Russia, nor for the EU nor for Italy, which could otherwise improve [Italian-Russian] economic and trade relations". ${ }^{42}$ Nonetheless, on January 29, 2019, Denmark's Minister of Foreign Affairs Anders Samuelsen called for EU-wide increase of sanctions on Russia due to its actions in the Azov Sea, in addition to the preexisting sanctions,

\footnotetext{
40 Maarten Smeets, "Can Economic Sanctions Be Effective?" Economic Research and Statistics Division, World Trade Organization, March 15, 2018: 10.

${ }^{41}$ Matthew P. Goodman, Heather A. Conley, Jon B. Alterman, Jeffrey Mankoff, and Moises Rendon. "Are Sanctions Working?" Sanctions and Foreign Policy Speaker Series. Center for Strategic and International Studies. July 31, 2019: 3 .

42 Stefano Vergine, "Conte to Putin: EU sanctions on Russia make Italy 'sad'," EUobserver: Foreign affairs, July 5, 2019.
} 
believing that "the EU needs to react to Russia's aggressive behaviour". ${ }^{43}$ Likewise, on February 13, 2019 Prime Minister of Netherlands Mark Rutte pushed the EU to enforce a tougher sanctions approach stating that, "sometimes the EU forms a relatively unified and effective front [...] but more often the EU's action lacks teeth, as the agreement of all 28 member states is needed and sectional interests often come into play". ${ }^{44}$ Bulgaria's divide over sanctions and its quite strong relationship with Russia is due to its historical ties with Russia dating back to the Second World War, and its fears over energy security. ${ }^{45}$ On November 5, 2019, Swedish Foreign Minister Anne Linde affirmed her unwavering position to continue EU "sanction pressure". ${ }^{46}$ It is clear that within the EU, member states have held various stances on imposing sanctions on Russia due to a diversity of factors including internal political battles, diverse strategic interests and ties with Russia or lack thereof, popular belief among citizens towards utilizing sanctions against Russia, and shift in political leadership or mandate of the member state..$^{47}$

Further, the expanded lists of measures to the original sanctions package seemed to be linked to Russia's other actions, such as its linked poisoning of Sergei Skripal, Russia's GRU

\footnotetext{
43 Reuters, "Danish minister calls for EU-wide sanctions on Russia over Azov Sea,” World news. January 29, 2019.

${ }^{44}$ Eline Schaart, "Dutch PM Rutte: EU must get tough on sanctions,” Politico, February 13, 2019.

45 Vessela Tcherneva, "View from Sofia: A difficult choice between Russia and the West," European Council on Foreign Relations, March 9, 2015.

46 UNIAN, "Sweden to keep putting pressure on Russia through sanctions," Politics, November 5, 2019.

47 Martin Russell, "Sanctions over Ukraine: Impact on Russia," EPRS | European Parliamentary Research Service, January 2018;

Anke Schmidt-Felzman, “Is the EU's failed relationship with Russia the member states' fault?" L'Europe en Formation 4, no. 374 (2014): 40-60;

European Council on Foreign Relations, "What next for EU sanctions on Russia?" ECFR Views from the Capitals, 2015;

Kadri Liik, "Winning the Normative War with Russia: An EU-Russia Power Audit," European Council on Foreign Relations, May 2018;

European Commission, "Special Eurobarometer 451: Future of Europe," Directorate-General for Communication, December 2016: 16.
} 
(Main Intelligence Directorate) attempt in hacking the OPCW (Organisation for the Prohibition of Chemical Weapons), and its involvement in downing MH17.48 The integration of restrictive measures into the overall sanctions package against Russia diluted the primary objectives of the original sanctions package, mixing several objectives into one package. These objectives, although related, are often not congruent with one another. If these objectives in total are nonnegotiable for the EU, then it could be significantly tougher to receive concessions from Russia. Directly attaching each set of measures with a given objective that could be resolved separately would break down a major dispute into smaller problems. However, in this case, these issues cannot be addressed on a separate basis, as they are not linked to separate sanctions packages. This, as one expert called it, "mishmash of objectives" with various sanctions measures disorganizes the link between the target state's costs and specific policy changes that the West would like the Russian government to undertake. ${ }^{49}$ This strategy has led some Russian officials believing that this is the 'new normal', which does not work in the sender states' favour as they would prefer to see a change in Russia's behaviour and work to eliminate sanctions. This perception of the 'new normal' reinforces the Russian government's perception of the need to focus on decoupling from the Western-led international economic order and to turn to other countries who are also looking to evade that order, such as China, Venezuela, and Syria. ${ }^{50}$

\footnotetext{
48 Reuters, "EU sanctions Skripal suspects, Russia calls move groundless," World news, January 21, 2019; Government of the United Kingdom, "Minister for Europe statement: attempted hacking of the OPCW by Russian military intelligence," Cyber security: Speech, October 4, 2018;

UN News, "UN chief notes 'with concern' report holding Russia liable for downing airliner," United Nations, May $25,2018$.

49 Matthew Goodman, Heather A. Conley, Jon B. Alterman, Jeffrey Mankoff, and Moises Rendon. "Are Sanctions Working?" Sanctions and Foreign Policy Speaker Series. Center for Strategic and International Studies. July 31, 2019: 3 .

50 Ibid, 4.
} 


\subsection{Sanctions' Impact}

EU sanctions, combined with likeminded partners' sanctions regimes and declining oil prices, had a devastating negative impact on Russia's economy and socio-economic standing. Sanctions had led to prolonged economic stagnation and lowered living standards. ${ }^{51}$ At the annual "Direct-Line" in 2019, President Putin addressed many of the economic challenges as issues borne out of sanctions, since Russia, by his statistics, lost around $\$ 50$ billion since 2014.52 The wide-spread agreement among impact assessments conclude that sanctions are not necessarily the conclusive cause that has created Russia's economic difficulties, however they have substantially exacerbated existing and arising issues by restricting Russia's economic flexibility, enhancing its vulnerability to shocks, prolonging economic stagnation, and making economic recovery more difficult. ${ }^{53}$ Russia's economy relies on its energy sector as it produces roughly $70 \%$ of Russia's export earnings and covers at least $47 \%$ of its federal budget, while its oil and natural gas exports account for more than $60 \%$ of Russia's exports and more than $30 \%$ of its GDP. ${ }^{54}$ Therefore, the combination of sanctions with the fall of the global oil prices led to an

51 Matthew Goodman, Heather A. Conley, Jon B. Alterman, Jeffrey Mankoff, and Moises Rendon. “Are Sanctions Working?" Sanctions and Foreign Policy Speaker Series. Center for Strategic and International Studies. July 31 , 2019: 8 .

52 Russia Today, “Russia: Putin discusses sanctions, Trump's Huawei ban at 'Direct Line',” Russia: RUPTLY, June 20, 2019;

The annual "Direct-Line" (or Прямая линия с Владимиром Путиным) is a live television program, supported and directed by the Kremlin Press Secretary where President Putin addresses citizens' questions.

53 Jarosław Ćwiek-Karpowicz, and Stanislav Secrieru. Sanctions and Russia. The Polish Institute of International Affairs. 2015: 47-50.

54 Martin Russell, "Sanctions over Ukraine: Impact on Russia," EPRS | European Parliamentary Research Service, January 2018;

Greg Depersio, "How does the price of oil affect Russia's economy?" Investopedia, April 11, 2019;

Tsvetana Paraskova, "Russia's oil revenue is about to soar," Business Insider, May 14, 2018;

Statista Research Department, "Russian federal budget oil and gas revenue 2016-2019," Statista: Fossil Fuels, February 2020;

MINFIN Rossii, "Federalniy Byudzhet," Statistika, 2020. 
increasingly tougher economic situation. Sanctions have induced capital and investment flight, as well as fear among future investors. Correspondingly, Russia has undergone fiscal difficulties, hindered access to financing for development, a decrease and prolonged stagnation in its currency (ruble), and rising inflation. These aspects have caused other challenges as the Central Bank of Russia tried adopting a policy of monetary tightening by further increasing its interest rates - hiking policy rates by 200 basis points within months. ${ }^{55}$ This particular maneuver discouraged investment and consumption, which stifled growth. This is clearly exemplified by the decrease of Foreign Direct Investment (FDI) in Russia from $\$ 10$ billion per quarter before 2014 to negative net flows in 2015.56

Although there was a plethora of analysis completed on the negative economic impacts of sanctions on the Russian economy already, President Putin in November of 2014 explained that economic damage was difficult to calculate. ${ }^{57}$ Nonetheless, at the same time, Russia's Minister of Finances Anton Siluanov confirmed that sanctions caused an enormous decrease in the inflow of direct investment and credit. Siluanov definitively declared that it had cost Russia approximately \$40 billion, which was added to Russia's overall outflow of investments to about $\$ 130-140$ billion per year. ${ }^{58}$ Moreover, observing the origin of foreign investments into Russia causes

\footnotetext{
55 Larry Elliott, "Russian central bank raises interest rate to 17\% to prevent rouble's collapse," The Guardian: Europe, December 15, 2014;

Anatoly Kurmanaev, "Russia Central Bank Raises Interest Rates in Effort to Stem Economic Risks," Wall Street Journal, December 14, 2018;

Bank Rossii, "Bank Rossii prinyal resheniye snizit klyuchevuyu stavku na 50 b.p. do 5.5\% godovykh," Press-relis, April 24, 2020.

${ }^{56}$ CEIC Data, "Russia Foreign Direct Investment,” Countries/Regions: Russia, 2020.

${ }^{57}$ Euronews (na russkom), "Minfin Rossii podschital usherb ot sanktsiy i obvala tsen na neft - economy," Russia: Euronews, Youtube, November 24, 2014.

58 Rossiya 24, "Ministr finansov: Rossiya nayuchena sankstiyami SSHA - doly dollara byudet snizhena - Rossiya 24,” Russia: Rossiya 1, Youtube, December 11, 2019.
} 
further questions. The Russian Central Bank reported that the top five investing countries were Cyprus (36.8\%), Netherlands (9.2\%), Bermuda (7.2\%), Bahamas (5.8\%), and Luxembourg (4.4\%). ${ }^{59}$ However, a United Nations Conference on Trade and Development (UNCTAD) model shows that much of foreign investment is Russian capital that arrives through intermediary countries, such as Cyprus, Bermuda, and Bahamas. ${ }^{60}$

Taking into consideration a number of economic indicators, Russia's economy took on immediate and substantial negative impacts. Russia's GDP was on the rise since 2009, where in 2013 it had reached its peak: $\$ 2.3$ trillion. ${ }^{61}$ Immediately after the implementation of sanctions in 2014, Russia's GDP began to decrease resulting in its lowest GDP level in a decade: \$1.28 trillion (2016) — nearly half of its 2013 level. ${ }^{62}$ However, observing oil prices during the same time, Russia's GDP nearly mirrors both the drop and rise in oil prices. ${ }^{63}$ Therefore, it is necessary to review other economic indicators that would be more indicative of sanctions' impact and their enhancement of Russia’s economic vulnerability. Russia’s total value of exports also decreased significantly after sanctions. Russia's value of exports had peaked between 2011 and 2014 averaging approximately $\$ 492$ billion — while after sanctions, value of exports declined by $43 \%$

\footnotetext{
59 Leonid Bershidsky, “Where Russia’s Foreign Investment Really Comes From,” Bloomberg: Politics and Policy, November 6, 2019.

60 Ibid.

61 World Bank, “GDP (current US\$) - Russian Federation,” Based on World Bank data, national data, and OECD National Accounts data, 2019;

Some of the GDP decrease can also be attributed to currency devaluation.

62 Ibid.

${ }^{63}$ Macrotrends, "Crude Oil Prices - 70 Year Historical Chart," Based on West Texas Intermediate (WTI or NYMEX) crude oil prices per barrel, 2020.
} 
from 2014 to $2016 .{ }^{64}$ Russia's inflation rate stayed around 7\% from 2010 to 2014, but after sanctions, it spiked to levels above $15 \%{ }^{65}$ After sanctions, Russia's currency immediately devalued from around 33 rubles per USD to 64 rubles per USD, with a high of 79 in the beginning of $2016 .{ }^{66}$ Russia's federal budget also recorded a larger deficit than before sanctions, falling from $-0.5 \%$ of GDP to $-3.4 \%$ of GDP. ${ }^{67}$ Between 2013 and 2014 the federal budget hovered around a $\$ 10.9$ billion deficit, and then sunk to a $\$ 36.4$ billion deficit in 2015 , and further in 2016 to $\$ 40.6$ billion. ${ }^{68}$ This was largely due to Russia’s ever-increasing expenditures not balanced by a steady increasing in government revenue — due to the lack of oil and gas revenues. In 2019, the Under Secretary for Terrorism and Financial Intelligence (US Treasury) Sigal Mandelker stated that sanctions led to a decrease in Russia's FDI due to major Western firms abandoning joint exploration ventures with Russian companies, and that by "expos[ing] and disrupt[ing] the malign activity of Russian oligarchs," Russian oligarchs were forced to divest ownership in large corporations. ${ }^{69}$ Russia's decision to increase the pension ages also shows its difficulty in managing the national budget. The decision was a known unpopular

64 World Bank, "Export value index $(2000=100)$ - Russian Federation,” Based on United Nations Conference on Trade and Development, Handbook of Statistics and data files, and International Monetary Fund, International Financial Statistics, 2019.

65 World Bank, "Inflation, consumer prices (annual \%) - Russian Federation,” Based on International Monetary Fund, International Financial Statistics and data files, 2019.

66 Currency depreciation was also a product of decreasing global oil prices, with sanctions exacerbating the ruble depreciation;

Andrew Chatzky, "Have Sanctions on Russia Changed Putin's Calculus?" Council on Foreign Relations: In brief, May 2, 2019;

Ladislav Tyll, Karel Pernica and Markéta Arltová, "The impact of economic sanctions on Russian economy and the RUB/USD exchange rate," Journal of International Studies 11, no. 1 (2018): 27-28;

XE, "XE Currency Charts: RUB to USD, ” XE Currency Charts, Accessed May 21, 2020.

${ }^{67}$ MINFIN Rossii, “Federalniy Byudzhet,” Statistika, 2020.

68 Ibid.

69 Sarah Ladislaw, Sigal Mandelker, and Dr. John Hamre “Are Sanctions Working?” Welcome and Opening Remarks

+ Keynote, Center for Strategic and International Studies, July 31, 2019: 2. 
decision with a large majority of Russians, where President Putin released a rare personal video statement to indicate the necessity of this unpopular decision. ${ }^{70}$ Furthermore, Russia's stateowned Channel One surprisingly showed that $65 \%$ of Russians cannot save and do not have assets due to the looming economic difficulties, and that inflation is damaging economic growth and having an effect on salaries and pensions..$^{71}$

\subsection{Sanctions Impact: Russia's Rejection of Sanctions'Aims}

Even with evident economic and socio-economic impacts on Russia, Russia has largely yet to concede to the aims of the EU's sanctions discussed in the first section of this Chapter. Russia's steps forward, or concessions, could include the withdrawal of Russian forces from Ukraine, the return of the Crimean peninsula to Ukraine, and/or meeting other key points of the Minsk II Agreement. According to the Minsk II Agreement's 13 points, Russia has not taken any steps to ensure that the Organization for Security and Co-operation in Europe (OSCE) can permanently monitor the Ukrainian-Russian border and have guaranteed access to key security zones in the border regions of Ukraine and Russia. Russia has also not ensured measures to improve the humanitarian situation in Donbass, nor has there been a withdrawal of illegal armed groups and military equipment (including fighters and mercenaries) from the territory of

\footnotetext{
70 Andrew Roth, "Russian MPs pass unpopular bill to raise pension age," The Guardian, September 27, 2018; RUPTLY, "Russia: Putin waters down unpopular retirement age increase," Russia: RT, Youtube, August 29, 2018.

${ }^{71}$ Perviy Kanal, "Gost Anton Siluanov. Pravo na spravedlivost. Vypusk ot 22.10.2019," Russia: Perviy Kanal, Youtube, December 2, 2019. 
Ukraine. ${ }^{72}$ Although Russia has made little attempt to take major steps forward towards these sanctions goals, it has agreed to two prisoner exchanges at the end of 2019, which does partially fulfill point 6 of the Minsk II agreement. ${ }^{73}$

As per point 6 of the Minsk II Agreement — "release and exchange all hostages and illegally held persons, based on the principle of 'all for all"' — Ukraine and Russia have come to an agreement and Russia has taken steps forward in this section of the agreement. ${ }^{74}$ Two exchanges occurred, one in September and the other in December of 2019 under the supervision of international observers, with approximately 200 prisoners exchanged. ${ }^{75}$ Although it is unsurprising that Russia negotiated the return of some of its citizens such as RIA Novosti

72 Organization for Security and Co-operation in Europe, Kompleks mer po vypolneniu Minskikh soglasheniy, September 5, 2014; Spestialnaya monitoringovaya missiya v Ukraine, "Tendenstii i nabludeniya 2019," Organizatsiya po bezopastnosti i sotrudnichestvu v Evrope, 2019;

Stefan Lehne, "REVIVING THE OSCE European Security and the Ukraine Crisis," Carnegie Endowment for International Peace, 2015: 6-9;

Spestialnaya monitoringovaya missiya v Ukraine, "Tematucheskiy Otchet - Ogranicheniya svobody peredvizheniya i drugie prepyatstviya v vepolnenii mandata CMM: Yanvar-Iun 2019," Organizatsiya po bezopastnosti i sotrudnichestvu v Evrope, September 2019.

${ }^{73}$ It is worth mentioning that it is difficult to link Russia's positive step towards a prisoner exchange as a direct result of sanctions. Russia's official point of view on these exchanges was that of building trust with Ukraine, moving towards a political settlement in the region, and achieving peace.

74 Organization for Security and Co-operation in Europe, Kompleks mer po vypolneniu Minskikh soglasheniy, September 5, 2014.

${ }^{75}$ Kim, Lucian, and Steve Inskeep. "Prisoner Exchange Is A Positive Sign In Russia-Ukraine War." NPR: Europe. December 30, 2019;

Amidst the total of 200 prisoners, some high-profiled prisoners were exchanged including 24 Ukrainian sailors detained from the Kerch Strait incident, Ukrainian filmmaker and activist Oleg Sentsov, 5 Ukrainian Berkut officers accused of killing protesters during Euromaidan in Kiev, and RIA Novosti Ukraine editor-in-chief Kirill Vyshinsky; In 2018, Russian ships intercepted and rammed one Ukrainian tugboat in the Kerch Strait, and captured the sailors on the ship. Oleg Sentsov filmmaker and activist from Crimea who was sentenced to 20 years in a Russian prison on charges of terrorism in August 2015. Upon returning to Russia, Vyshinsky was immediately placed as the Executive Director of Rossiya Segodnya. After both prisoner exchanges, Kiev received 76 and Donbass received 124;

Andrew Roth, "Kerch strait confrontation: what happened and why does it matter?" The Guardian, November 27, 2018;

Masha Gessen, "The Release of Oleg Sentsov and the Plight of Those Left Behind," The New Yorker, September 10, 2019 ;

UA 112, "Vyshynsky appointed as executive director of one of Russian mass media," UA 112, October 7, 2019; Agence France-Presse in Mayorske, "Ukraine and Russia-backed separatists exchange 200 prisoners," The Guardian, December 29, 2019. 
Ukraine editor-in-chief Kirill Vyshinsky, what is notable in this exchange is that Russia negotiated on returning detained fighters for separatists groups in Donbass. Further in this exchange, separatists groups handed back their detainees. Therefore, these instances provide additional evidence substantiating Russia's influence over pro-Russian separatists. ${ }^{76}$

President Putin and Ukrainian President Volodymyr Zelensky agreed that there is now a "thaw" in Russian-Ukrainian relations due to the prisoner exchange, reduction of armed forces in three key security points, and the continued Normandy Format meetings. ${ }^{77}$ Right after the December 29, 2019, exchange and the promise of having a consistent flow of natural gas to Europe, both President Putin and President Zelensky spoke in favour of developing relations in 2020. ${ }^{78}$ German Chancellor Angela Merkel and French President Emmanuel Macron praised the December Normandy meeting and the progress made recently — both leaders of sender states part of the EU's sanctions policy towards Russia.79 President Putin insisted that Russia is still looking for Ukraine to amend its constitution to acknowledge the status of Donbass with permanent special status, agreeing on the special status of Luhansk and Donetsk regions, and giving amnesty and implementing a legal ban on criminal prosecution of people who took part in

\footnotetext{
76 BBC News, “Ukraine and pro-Russian separatists exchange prisoners," BBC: Europe, December 29, 2019.

77 RUPTLY, “France: Putin and Zelensky praise 'positive' meeting and 'thaw' in relations," Russia: RT, Youtube, December 9, 2019;

United Nations Security Council, "Upcoming Period Will Be Crucial to Resolution of Conflict in Ukraine, International Officials Tell Security Council,” Meetings Coverage: 8726th meeting SC/14112, February 18, 2020.

78 Prezident Rossii, "Telefonniy razgovor s Prezidentem Ukrainy Vladimirom Zelenskim,” Novosti: Sobytiya, December 31, 2019.

79 Ibid.
} 
the 'events' in Ukraine's south-east. ${ }^{80}$ Further, President Putin mentioned that Russia would welcome the recreation of a G8 if the G7 countries were to accept. ${ }^{81}$ It is evident that Russia is still not willing to take any further steps unless Ukraine takes equal steps in the agreement, as outlined above, and thus, has laid out a series of demands for both Ukraine and indirectly with sender states. Moreover, President Putin mentioned at the Normandy format peace talks that natural gas could be $25 \%$ cheaper for the end consumer, as if placing an incentive (or positive sanctions) on both Ukraine and European sender states. ${ }^{82}$ Despite the fact that President Putin stated relations between Ukraine and Russia will inevitably normalize as they are "one people," Russia has a list of requirements that also need to be met for it to take steps forward. ${ }^{83}$

The prisoner exchanges in 2019 was a significant step in improving current ties between Russia and Ukraine, and an essential first step for Ukraine's newly elected President Zelensky who is attempting to negotiate with Russia and establish peace in eastern Ukraine — as part of his political platform. It is a tangible product of peace negotiations between Ukraine and Russia. Nonetheless, it is still the only point of the Minsk II Agreement that has been implemented by Russia, and major hurdles still lie ahead in the negotiations. These exchanges do not guarantee

\footnotetext{
${ }^{80}$ Bloomberg QuickTake. "Putin, Zelensky Agree to Prisoner Exchange, Revive Peace Process." France: Bloomberg. Youtube. December 9, 2019;

RUPTLY, "France: Putin and Zelensky praise 'positive' meeting and 'thaw' in relations," Russia: RT, Youtube, December 9, 2019;

President Putin is referring to points 6 and 9 of the full Russian version found here:

Organization for Security and Co-operation in Europe, Protokol: po itogam konsultatsiy Trekhstoronneiy knotaktnoiy gruppy otnositelno sovmestnykh shagov, napravlennykh na implmentaziu Mirnogo plana Prezidenta Ukrainy P. Poroshenko i initsiativ Prezidenta Rossii V. Putina, February 12, 2015.
}

${ }^{81}$ RUPTLY, "Russia: Moscow and Kiev finalising negotiations on large-scale prisoner swap - Putin," Russia: RT, Youtube, December 9, 2019.

82 RUPTLY, "France: Putin and Zelensky praise 'positive' meeting and 'thaw' in relations," Russia: RT, Youtube, December 9, 2019.

${ }^{83}$ RUPTLY, "Russia: Moscow and Kiev finalising negotiations on large-scale prisoner swap - Putin," Russia: RT, Youtube, December 9, 2019. 
that Russia will return Crimea, nor that it will implement other components of the Minsk II Agreement. ${ }^{84}$ Prisoner exchanges have occurred in 2016 and 2017, as Ukraine and Russia negotiated the exchange of more than 300 prisoners with positive remarks on building trust and momentum to achieve peace in the region. ${ }^{85}$ However, even with these attempts, the conflict is still ongoing and Russia has yet to take any other steps towards sanctions' aims.

On the other hand, it could be said that this situation is more complex when considering Ukraine's contribution to the Minsk II Agreement. Russia has consistently suggested that Ukraine has struggled to fulfill its part of the Minsk II Agreement, and it could be that Russia is maintaining pressure from the EU via sanctions on one end and waiting for Ukraine's contribution to the Minsk II Agreement on the other end. Thus, arguing that the EU could also focus on encouraging Ukraine to fulfill its part of the negotiations, and help resolve the conflict and the sanctions situation. In response, the EU indicates that Ukraine has worked hard to deliver the September and December 2019 prisoner exchange — releasing more prisoners than Russia — and as the Council of the EU notes in 2019, Ukraine was also instrumental in:

"the completion of de-mining and dismantling of fortifications within the Stanytsia Luhanska area, the disengagement at Zolote and Petrivske areas, and the agreement on the so-called 'Steinmeier formula' on 1 October, concerning the holding of local elections in the non-government controlled areas of eastern Ukraine, as part of the

\footnotetext{
${ }^{84}$ Russia has indicated through the prisoner exchanges that it will implement Minsk II Agreement points if they are done equally and at the same time.

85 Marc Bennets, "Ukraine and separatists begin largest prisoner exchange of conflict," The Guardian, December 27, 2017;

Prezident Rossii, "Vladimir Putin podderzhal predlozheniye Viktora Medvedchuka ob obměna plennymi mezhdu Ukrainoy i Donetskoy i Luganskoy respublikami," Novosti: Sobytiya, November 15, 2017;

Andrew Kramer, "Ukrainian Pilot, Nadiya Savchenko, Is Exchanged for 2 Russian Prisoners," The New York Times, May 25, 2016.
} 
implementation of the Minsk agreements [... while] Russia has yet to match the constructive steps taken by Ukraine". 86

On October 1, 2019, Ukraine's President Zelensky agreement to fulfil the Steinmeier formula, in particular, is a sign of Ukraine's willingness to implement its side of the Minsk II Agreement albeit cautiously. Agreement to the formula is Ukraine's step forward to meeting Russia's needs of the Minsk II Agreement. ${ }^{87}$ The formula essentially suggests incremental steps, which enables the gradual special status for Donetsk and Luhansk and local elections. ${ }^{88}$ This is a significant step from Ukraine's side, as recent popular demonstrations and civil societies have displayed disagreement with Ukraine agreeing to the formula. A recent poll suggests that most Ukrainians $(56 \%)$ disagree with this formula, and prefer to retake Donetsk and Luhansk as before $2014 .{ }^{89}$ In addition, Ukrainian veterans, opposition political parties, civil-society groups, and Ukrainian ultra-nationalists have countered the government of Ukraine's agreement to the Steinmeier Formula. 90

\footnotetext{
86 European Commission, "JOINT STAFF WORKING DOCUMENT: Association Implementation Report on Ukraine," High Representative of the Union for Foreign Affairs and Security Policy, SWD(2019) 433 final, December 13, 2019: 8 .
}

87 Organization for Security and Co-operation in Europe, Kompleks mer po vypolneniu Minskikh soglasheniy, September 5, 2014.

${ }^{88}$ Roman Goncharenko, "Ukraine conflict: Can the Minsk-2 peace deal with Russia be salvaged?" DW: Europe, February 12, 2020;

Christopher Miller, "Explainer: What Is The Steinmeier Formula -- And Did Zelenskiy Just Capitulate To Moscow?" RadioFreeEurope, October 2, 2019;

Halya Coynash, "Majority of Ukrainians against 'special status' for occupied Donbas," Kharkiv Human Rights Protection Group: Politics and Human Rights, October 16, 2019.

89 One day after the signing of the Steinmeier Formula, The Rating Group found that 59\% of respondents did not have an opinion, and that only $23 \%$ opposed the formula. One week later The Razumkov Center found that the numbers increased to represent $56 \%$ of those who opposed;

Reyting, "Stavlennya Ukraintsiv do virishennya pitannia okypovanix teritoriy," The Rating Group, October 2, 2019; Razumkov Tsentr, "Gromadska dumka pro situatsiu na Donbasi ta shlyahi vidnovlennya syverenitetu Ukraini nad okypovanimi teritoriyami," Razumkov Tsentr, October 11, 2019.

90 Christopher Miller, "Explainer: What Is The Steinmeier Formula -- And Did Zelenskiy Just Capitulate To Moscow?" RadioFreeEurope, October 2, 2019. 
At the same time, President Zelensky clarified that local elections in Donetsk and Luhansk would be held under Ukrainian legislation and OSCE' supervision, and "if the OSCE judges the balloting to be free and fair, then a special self-governing status for the territories will be initiated".91 President Zelensky further clarified that the local elections would be held only, "after Russian forces are withdrawn and Ukraine regains control of the state border". 92 These are not extraordinary conditions; they are points stemming from the Minsk II Agreement. Therefore, the Ukrainian side has taken cautious steps forward, but also requiring certain Russian steps to implement the agreement. As a result, both sides agree to some extent to move forward with implementing points of the agreement, however, requiring the other side to implement their points first.

With regards to the return of Crimea back to Ukraine, Russia has been clear about its intentions of not permitting that under any circumstance. The key to eliminating individual and Crimean sanctions is prevented by Russia's non-negotiable stance on Crimea. As President Putin stated in a four-hour personal documentary film created by Russia's state-owned channel Rossiya 1 in 2018, "our Western partners must know that they cannot use such rude methods to negotiate with Russia". ${ }^{93}$ To the question, "are there any circumstances in which you would be able to return Crimea?" in the same interview President Putin definitively answered, "are you crazy?

\footnotetext{
${ }^{91}$ Roman Goncharenko, "Ukraine conflict: Can the Minsk-2 peace deal with Russia be salvaged?" DW: Europe, February 12, 2020;

Christopher Miller, "Explainer: What Is The Steinmeier Formula -- And Did Zelenskiy Just Capitulate To Moscow?" RadioFreeEurope, October 2, 2019;

Halya Coynash, "Majority of Ukrainians against 'special status' for occupied Donbas," Kharkiv Human Rights Protection Group: Politics and Human Rights, October 16, 2019.

92 Christopher Miller, "Explainer: What Is The Steinmeier Formula -- And Did Zelenskiy Just Capitulate To Moscow?" RadioFreeEurope, October 2, 2019.

93 Rossiya 24, "Putin. Film Andreya Kondrashova. Polnoe video," Russia: Rossiya 1, Youtube, March $24,2018$.
} 
There will never be any such circumstances, ever". ${ }^{94}$ Russia has clearly stated its intentions of keeping Crimea under its federation, and will never, as President Putin dictates, return it. In addition, Russia reinforced its position by continuing to deploy unmarked military troops to Ukraine, supply separatists in eastern Ukraine, and further lead destabilization efforts in Ukraine — which provides additional evidence of Russia's failure to implement the Minsk II agreement as discussed prior. ${ }^{95}$

\subsection{Reviewing EU's Strategy Using Nephew's Framework}

Based on Nephew's framework of an effective sanctions strategy, this section will evaluate the EU's sanctions strategy by analyzing the variety of sanctions and the way they were used through a six-step structure. ${ }^{96}$ An effective strategy, based on this criteria, would utilize a combination of diplomatic, military, technological, and economic sanctions. The six-step framework outlines how the sender state should: i) identify sanctions' aims, directly connect sanctions to the aims, and define minimum necessary remedial steps for the target state to take in order to remove sanctions, ii) understand the nature of the target state (vulnerabilities, interests, commitment to its actions that prompted sanctions) and its readiness to absorb or avoid sanctions, iii) develop a careful, efficient, and targeted strategy to increase sanctions effects on vulnerabilities, iv) monitor the execution of the sanctions strategy, continuously recalibrate the strategy to avoid target state resolve, and work on improving the strategy, v) present the target

\footnotetext{
${ }^{94}$ Rossiya 24, "Putin. Film Andreya Kondrashova. Polnoe video," Russia: Rossiya 1, Youtube, March 24, 2018. 95 Steven Pifer, "Five years after Crimea's illegal annexation, the issue is no closer to resolution," The Brookings Institution, March 18, 2019.

96 Nephew, The Art of Sanctions: A View From the Field, 4.
} 
state with a clear statement of conditions necessary for the removal of sanctions, and offer to pursue negotiations necessary to conclude an arrangement that removes sanctions while satisfying sender states' requirements, and vi) accept the possibility that, even with an adequate strategy, the sanctions regime may fail to change the target state's behaviour due to inherent inefficiencies in the strategy, a misunderstanding of the target state, or an exogenous component in the target's resolve and capacity to resist — in any case, the sender states should be prepared to either acknowledge their failure and change the strategy, or accept the risk of continuing with its present course that could produce worse outcomes in the long run. ${ }^{97}$

In Nephew's analysis of sanctions against Russia, he affirmed that sender states have imposed the most serious, expansive, and the "most significant demonstration of coercive diplomacy". 98 The EU sanctions package does include the full variety of sanctions. As part of Nephew's framework, diplomatic and political sanctions impose damage to the target state's standing that limits its international capacities, negotiations, and other diplomatic means. ${ }^{99}$ The EU has deployed this type of sanctions successfully through the G8 when it led the group to not only relocate the 2014 Sochi summit but to remove Russia from the group, which became the G7.100 18 EU member states together with numerous partner states have also expelled over 100 Russian diplomats due to the poisoning of Sergei and Yulia Skripal in 2018 - although not necessarily connected to the conflict in Ukraine, the cascading tensions created by sanctions and

\footnotetext{
97 Nephew, 4.

98 Ibid, 156.

99 Ibid, 44.

100 Jim Acosta, “U.S., other powers kick Russia out of G8," CNN politics, March 24, 2014.
} 
Russian international isolation led to this strong reaction. ${ }^{101}$ However, sender states failed in this respect when the Council of Europe readmitted Russia after a five year suspension over Crimea in 2019.102 Offers by the US administration in 2019 to open the question of readmitting Russia to the G7 also shows a deficiency in maintaining diplomatic sanctions against Russia. ${ }^{103}$ As US President Donald Trump, French President Emmanuel Macron, and German Chancellor Angela Merkel deliberated on the potential reintegration of Russia into the G7, UK, Canada, and the EU (represented by EU Council President Donald Tusk) vehemently disagreed. They indicated that Russia will not return to the G7 while occupying Ukraine. ${ }^{104}$ This division in the sender states inhibits their ability to enforce strong and unified diplomatic sanctions against Russia. Moreover, compared to other past target states of the EU sanctions regime, Russia's international reach and participation is unprecedented. Russia is a major player in many key regions, including the Middle East, North Africa, the Arctic, and Eastern Europe, effectively surrounding the EU; Russia also participates and holds powerful international tools such as its United Nations Security Council Permanent Member (P5) seat, and participation in the Organization for Security and Co-operation in Europe (OSCE), the Shanghai Cooperation Organisation (SCO), Association of Brazil, Russia, India, China, and South Africa (BRICS), World Trade Organization (WTO), and the Asian Pacific Economic Cooperation (APEC).

\footnotetext{
101 Angela Dewan, "These are all the countries that are expelling Russian diplomats," CNN, March 28, 2018. 102 Gilbert Reilhac, "Council of Europe readmits Russia, five years after suspension over Crimea," Reuters: World News, June 25, 2019.

103 Julian Borger, “G7: Trump's demands for Russia's readmission cause row in Biarritz," The Guardian, August 25, 2019.

${ }^{104}$ France-24, “Russia readmission divides leaders at Macron's G7," France: AFP, August 26, 2019.
} 
The EU has also implemented military sanctions with the objective of denying access to military hardware and technical assistance, which is covered under the ban on arms trade, dualuse goods restrictions, financial restrictions on defence companies, and listing Russia's defence individuals and entities. ${ }^{105}$ Military sanctions, as per Nephew's theory, try to create domestic political pressure since the defence sector is usually a major component in developing foreign policy — as is the case with Russia. This is also done to put a strain on Russia's military forces, hopefully limiting its use and capabilities in other foreign pursuits. This is clear when observing the Stockholm International Peace Research Institute's (SIPRI) most recent Arms Transfers Database which showed that Russia's arms exports decreased by 18\% between 2015 and 2019 when compared to 2010-2014.106 Although sender states have imposed stringent sanctions on Russia's defence sector, they have not looked to apply secondary sanctions against secondary states that allow Russia to bypass these restrictions, and especially those states that are looking to purchase Russian weapons.

Venezuela has imported billions of dollars' worth of Russian arms and defence loans from 1999 until present moment, as Venezuela continues to import. ${ }^{107}$ India has become a major consumer of Russian weapons, ordering an unprecedented $\$ 14.5$ billion worth of Russian weapons between 2018 and 2019.108 Turkey, a NATO member state, has also purchased S-400

\footnotetext{
105 Nephew, 45.

106 Pieter D. Wezeman, Aude Fleurant, Alexandra Kuimova, Diego Lopes Da Silva, Nan Tian and Siemon t. Wezeman, "Trends in International Arms Transfers, 2019," Stockholm International Peace Research Institute: Fact Sheet, March 2020.

107 Ryan C. Berg and Andres Martinez-Fernandez, "Venezuela Is Armed to the Hilt,” Foreign Policy, May 2, 2019. 108 Moscow Times, “India's Russian Arms Purchases Hit 'Breakthrough' \$14.5Bln, Official Says,” Moscow Times, September 5, 2019.
} 
systems in 2019 for approximately \$2 billion, while Syria purchased Russia’s older S-300 systems. ${ }^{109}$ China has also purchased various Russian weapons including Su-35 fighter jets and S-400 missiles in 2018.110 Russian Presidential Aide for Military Cooperation, Vladimir Kozhin, boasted that China's military contracts amounted to $\$ 7$ billion in 2018. Egypt signed a \$2 billion agreement with Russia to purchase at least 20 Su-35 fighter jets. ${ }^{111}$ Algeria, Indonesia, Vietnam, Pakistan, and Iran either already purchased or are looking to purchase Russia fighter jets, strategic bombers and tanks. ${ }^{112}$ Iran's UN arms ban will expire in 2020, which will give Russia the perfect chance to veto the restoration of the ban and to supply Iran with arms — Iran has already proposed to purchase Su-30 fighters, Yak-130 trainers, T-90 tanks, and S-400 air-defence system. ${ }^{113}$

The US, unlike the EU, has implemented extraterritorial sanctions against most of these states (or at least threatened to implement) in an attempt to fulfill Nephew's strategic point of punishing secondary states and further isolate Russia. ${ }^{114}$ The US has done this through a 2017 legislation called Countering America's Adversaries Through Sanctions Act (CAATSA), which

\footnotetext{
109 Tim Lister, "Turkey bought Russian S-400 missiles designed to down NATO planes. For the US, that's a problem," CNN World, July 13, 2019;

Ryan Pickrell, "Moscow to arm Syria with advanced anti-aircraft missiles after a massive air battle downed a Russian plane," Business Insider, September 24, 2018.

110 BBC News, "US imposes sanctions on China for buying Russian weapons," BBC News: US \& Canada, September 21, 2018.

111 Al-Jazeera, "US may impose sanctions on Egypt over Russian fighter jet deal," AJ Impact: United States, November 18, 2019.

112 Alec Luhn, "Russia's campaign in Syria leads to arms sale windfall," The Guardian, March 29, 2016; Jack Detsch, "Report: Iran likely to buy Russian and Chinese arms,” Al-Monitor, November 19, 2019.

113 Henry Meyer, “Russia Rejects Extending Iran Arms Embargo, Defying U.S.,” Bloomberg, December $27,2019$.

114 Also known as sanctions with extraterritorial impact. More information can be found here:

Jonathan Masters, “What Are Economic Sanctions?” Council on Foreign Relations, August 12, 2019.
} 
targets a series of sectors and actions that secondary states could be involved in, including arms deals. This legislation gives power to threaten or introduce sanctions against those secondary states with the objective of persuading them not to aid the target state. ${ }^{115}$ Although the US has threatened and imposed sanctions against these secondary states, most still executed their defence contracts with Russia. This could be explained by Drezner's theory of adversaries and allies, where adversaries are less likely to concede to the sender state than their allies. ${ }^{116}$ Observing Russia's military deals above, their customers are usually close allies or at least partners, while also adversaries with the West. Due to the three-fold combination of Drezner's theory of adversaries, the secondary states' close connection with Russia, and the secondary states rejection of the West, the secondary sanctions might not prove to be effective. Further, even with EU defence-related sanctions, Russia continues to develop its military and nuclear capabilities, and continues to export its military hardware.

Technological sanctions restrict the transfer of specific goods or services that could support the development of weapons of mass destructions (WMD), chemical, biological, radiological and nuclear $(\mathrm{CBRN})$ programs, space militarization programs, and other programs. Its objective is to impair technological development of the target state, in order to prevent the target state from developing programs intended for malign use, and designed for longer term implications. ${ }^{117}$ EU's restrictions also include technological sanctions by imposing restrictions on Russia's oil, gas, and defence sectors; listing specific biological and chemical goods; and by

\footnotetext{
115 One hundred fifteenth Congress of the United States of America, "Countering America's Adversaries Through Sanctions Act," Authenticated U.S. Government Information GPO, January 3, 2017.

116 Drezner, 307-308.

117 Nephew, 45.
} 
listing Russia's tech-industry such as Rostec. However, the impacts of these sanctions remain to be unseen as they usually take many years, if not decades, to realize any potential. There is a possibility that these sanctions will be able to create substantial damage to Russia since it is currently struggling with promoting domestic innovation, research, and development. 118 Although listing more products that are required for the production of oil and gas could be devastating for Russia, this could also be detrimental to the EU in the long run as it relies on Russian-imported oil and gas — which will be further discussed in Chapter 4.

Finally, economic sanctions primarily target financial vulnerabilities with the objective of damaging the target state's ability to obtain and use economic resources, punishing the target state through economic means, and undermining its means to act in the future. ${ }^{119}$ This type of sanctions can focus on trade and finance-related measures. This is where the EU's sanction regime seems to be limited. Although the EU has placed comprehensive financial restrictions on several key sectors of the Russian economy, it has not gone as far as placing targeted trade restrictions on oil and gas sectors. While both defence and energy sectors are targeted through finance-related measures, the EU's trade restrictions largely target Russia's defence sector. Therefore, the EU has identified these sectors as the major economic vulnerabilities but has stopped short of placing any energy-related trade restrictions. The EU has also stopped short of listing certain Russian entities and individuals involved in the energy sector and other key Russian defence companies. Again, the EU has also not enacted any secondary financial or trade

\footnotetext{
118 Apurva Sanghi and Shahid Yusuf, “Russia’s Uphill Struggle with Innovation,” World Bank, September 17, 2018.

119 Nephew, 46.
}

Demyan Plakhov 
sanctions, such as energy transportation insurance, that would attempt to prevent secondary states trading with Russia in defence or energy-related projects.

Nephew suggests that a well-developed sanctions strategy would utilize all four categories. ${ }^{120}$ From the aforementioned analysis, the EU has used all four categories in various degrees. However, the EU could unquestionably apply additional pressure through some categories, especially with regards to the oil and gas sector through trade-related sanctions and applying secondary sanctions. The reason behind the EU not including such sanctions helps introduce how the EU has a certain interdependence with Russia and may be limited in applying more pressure through sanctions. Utilizing the first three of the four categories, the EU has decided to pursue a longer-term strategy which may help explain why sanctions might be ineffective after only 5 years. ${ }^{121}$ For instance, the Iran case that Nephew primarily relied on for his theory framework took 14 years until some concessions were made by Iran. The damage created by restricting crucial technology to liquefy natural gas in 1996 - which limited Iran's export capability and crucial economic income — became visible only in $2010 .{ }^{122}$

The first of Nephew's six-step approach necessitates the EU to identify sanctions' aims to Russia, directly connect the particular sanctions to those aims, and define minimum necessary remedial steps that Russia must take in order to remove sanctions. The EU has established most of its aims clearly, as discussed before, but remedial steps have been less clear. Originally, Nephew outlined, the US and EU official statements were "ambiguous and somewhat

\footnotetext{
${ }^{120}$ Nephew, 48.

121 Nephew, 48.

122 Ibid, 48.
} 
contradictory on how sanctions would be reversed," but ascertained that by 2016 the US and EU officials resolved that the majority of sanctions would be relieved if Russia implemented the Minsk II Agreement. ${ }^{123}$ Nephew claims this meant that sanctions targeting specific individuals in relation to the Russian occupation of Crimea would remain as long as Crimea remained under Russian control. ${ }^{124}$ However, drawing from previous analysis of EU's sanctions' aims, although the reasons have been clear, there is still uncertainty as for the aims and remedial steps to lift the individual sanctions and sanctions against Crimea. With regards to remedial steps, although discussions are held consistently, the EU has not created any substantial results in negotiations since 2015 with Minsk II. ${ }^{125}$

The second part of the approach encourages the EU to completely understand Russia's vulnerabilities, interests, and its readiness to absorb or avoid sanctions, as well as Russia's commitment to interfering in Ukrainian sovereignty. 126 The EU has successfully targeted Russia's economic vulnerability and caused severe economic damage. Sender states exemplified considerable sophistication in targeted sanctions by identifying Russia's weaknesses and potential points of leverage, which helped the EU avoid self-inflicting costs. Sanctions were

\footnotetext{
${ }^{123}$ Nephew, 161.
}

124 In July 2019, the EU affirmed that sanctions will remain in place until "the Minsk agreements are fully implemented";

European Council, "Remarks by President Donald Tusk after the EU-Ukraine summit in Kyiv," Press releases: Statements and remarks, July 8, 2019.

125 As discussed previously in this chapter, although the prisoner exchanges were positive steps in implementing Minsk II Agreement, it did not mean there was no comprehensive implementation of other points included in the Minsk II Agreement. Furthermore, it is evidence of the fact that the EU has failed to connect any of the points from the Minsk II Agreement to its sanctions, resulting in no alleviation of sanctions when Russia has taken minor positive steps forward such as the prisoner exchanges. Given that the EU's sanctions policy does directly attach targeted sanctions to specific points of the Minsk II Agreement, it does not incentivize Russia to work on the agreement point by point.

${ }^{126}$ Nephew, 161. 
timed well, either by luck or design, with collapsing oil prices which amplified their impact. Nevertheless, the EU's sanctions strategy fell short in understanding Russian national values and readiness to absorb costs.

This leads to the third component, which necessitates that the EU must develop a careful, efficient, and targeted strategy to increase sanctions effects on Russian vulnerabilities. The sanctions campaign has been very patient, and it could be due to the fact that the EU relies on strong trade relations with Russia. ${ }^{127}$ Imposing tougher sanctions, which could have detrimental consequence for Russia especially in the natural resources sector, could have devastating consequences for Europe. At the same time, EU skepticism, EU's divisions, Brexit, the current US administration's unpredictable haphazard approach to Russian sanctions, and EU members' sanction skepticism have all diluted expectations about a resolute and unified sanctions regime against Russia. ${ }^{128}$ The EU, in using a patient approach, has undermined crucial momentum required in translating political concern into political concession. In fact, Drezner's models will show that it is far more effective to not use sanctions at all, and instead to threaten the implementation of the harshest sanctions' regime possible from the beginning. Nephew's analysis dictates that although sanctions have not been eased, the momentum has, and as a result, it becomes harder to transform sanctions' pressure into policy change. ${ }^{129}$ As increasing momentum was not used, and sanctions were applied slowly, Russia was able to absorb the pain caused by sanctions and adapt to the "new reality".

\footnotetext{
127 Nephew, 163.

128 Refer to Table 2.1 in Appendix A for further information on EU member states perspective on sanctions against Russia.

129 Nephew, 163-4.
}

Demyan Plakhov 
The fourth component requires the EU to monitor the execution of its strategy, continuously recalibrate the strategy to avoid Russia's resolve, and work on improving its strategy. ${ }^{130}$ The EU's ninth point of its 2004 basic principles outlines that the EU shall review sanctions regularly, "in order to ensure they are contributing towards their stated objectives". ${ }^{131}$ Based on this principle, the European Council reviews the restrictive measures every six months with the help of its relevant bodies such as the PSC, RELEX, and COREPER. ${ }^{132}$ Sender states are monitoring closely — by both delisting and expanding sanctions lists — however the strategy as a whole has not been recalibrated or greatly intensified since Russia has been able to find resolve. ${ }^{133}$ Moreover, it needs to be a section of a set of policy tools designed to change Russia's behaviour. Due to the EU's lack of unified defence structure and NATO's limited involvement in Ukraine, the EU has struggled to present military or other means of leverage in addition to its economic and diplomatic tools. Although the EU and other sender states, are still set on achieving the sanctions' objectives, it has yet to recalibrate its strategy in accomplishing this goal. After 2016, numerous economic indicators started showing that Russia is rebounding and developing better ways to avoid sanctions. Similarly, Nephew concludes that although economic damage has been done, it has not translated into actual pressure on the Russian government to change their foreign policy. ${ }^{134}$ Rather than compromise or concede to sanctions, Russia has been

\footnotetext{
130 Nephew, 164.

131 Council of the European Union, "Basic Principles on the Use of Restrictive Measures (Sanctions)," 10198/1/04 REV 1 PESC 450, June 7, 2004.
}

132 With the exception of sanctions placed on Crimea, which are reviewed every 12 months: Council of the European Union, "Infographic - EU sanctions against Russia over Ukraine," Infographics, May 8, 2020 .

133 Refer to Chapter 3 for Russia's avoidance, absorption, and resolve.

134 Nephew, 166. 
proactively seeking new markets and trading partners, especially in terms of their energy exports and financing. Therefore, Russia's strategy in 'managing the problem' caused by sanctions and finding ways around it rather than to accommodate sender states poses a severe risk to the effectiveness of the EU's sanction regime and requires serious strategy recalibration based on these circumstances.

The fifth component looks at presenting Russia with a clear statement of conditions necessary for the removal of sanctions and offering to pursue negotiations necessary to conclude an arrangement that removes sanctions while satisfying the EU and other sender states' requirements. The expectations, as pointed out before, are mostly clear, and Russia has rejected to concede to these expectations. This is entrenched in the ninth point of EU's basic principles for sanctions as it requires the EU to ensure that, "objectives [are] defined in the enabling legal instruments". ${ }^{135}$ Negotiations were also attempted, resulting in the 2014 Minsk agreement and the 2015 Minsk II agreement. However, the implementation of this agreement has not fully occurred, and negotiations since then have not resulted in any new major results. Moreover, the EU's limited interaction with Russia has restricted sanctions negotiations and opened the opportunity for Russia to negotiate on a bilateral basis with EU member states.

The sixth, and final, component necessitates that the EU and its partners should accept the possibility that, even with an adequate strategy, the sanctions regime may fail to change Russia's foreign policy due to inherent inefficiencies in the strategy, a misunderstanding of

\footnotetext{
${ }^{135}$ Council of the European Union, "Basic Principles on the Use of Restrictive Measures (Sanctions)," 10198/1/04
} REV 1 PESC 450, June 7, 2004. 
Russia, or an exogenous component in Russia's resolve and capacity to resist. ${ }^{136}$ Given the deadlock discussed in the previous component, it is likely that the strategy has failed thus far due to the combination of strategic insufficiencies, misunderstanding Russia's unwillingness to concede, and due to an exogenous boost in Russia's capacity to resist sanctions in various ways and even develop measures to adapt. Looking forward, sanctions can become effective in changing Russian foreign policy either by accepting the current failure and changing the strategy, or by continuing the current strategy in the hopes of seeing a new variable from Russia's side that will cause a change in its foreign policy behaviour. ${ }^{137}$

There are several gaps in the EU's sanction strategy that explain part of the reason why Russia has not changed its foreign policy. To briefly review the EU's gaps: a) did not use its full arsenal of possible sanctions, including secondary sanctions and trade restrictions on Russia's energy sector, b) completed gradual sanctions implementation allowing Russia to adapt, c) entered into a deadlock with Russia due to the non-negotiability of Crimea, d) has not clearly outlined recalibrated remedial steps, instead has relied on the Minsk II agreement from 2015, e) relied on sanctions as the major strategy rather than utilizing it as part of a larger policy framework accompanied by other methods, such as threat of use of force, and f) lacked understanding of Russia's resolve and unwillingness to concede. Although it seems that the EU and its partners have fulfilled, with varying degrees, all of Nephew's sanctions strategy components, the circumstances show that Russia is still able to maintain its original foreign

\footnotetext{
136 Nephew, 166.

137 Such as a change in executive leadership, including the President — which could be caused by internal upheaval, a strong civil movement, and/or internal government divisions.
} 
policy behaviour that prompted sanctions. Accordingly, it will be necessary to review how Russia's resolve and capacity enabled it to resist sanctions in the next chapter. Given that Russia has yet to change its policy, the EU will need to either accept its sanctions failure and change its strategy, or accept the risk of creating worse outcomes by continuing the same strategy — which is a beneficial introduction to sanctions' inadvertent effects discussed in Chapter 4, and helpful in discussing EU's options going forward in Appendix C. For instance, another extra component that made the Iran case successful in creating concessions - that Nephew did not mention as part of his framework but did credit for its success - was getting the UNSC to enforce several resolutions against Iran. ${ }^{138}$

138 United Nations Security Council, “2231 List,” Resolution 2231 (2015) on Iran Nuclear Issue, 2020. 


\section{Chapter 3: Russia's Capabilities and Circumstances}

\subsection{Introduction to Miyagawa and Russia's Capabilities}

Stemming from the previous chapter, Nephew also noted that "rejection and resistance to sanctions is the more traditional, expected response," which can definitely be applied to the Russia case here. ${ }^{1}$ Rejecting concessions, the target state instead seeks ways to avoid sanctions, either by establishing ties with secondary actors — including states, companies, or individuals or through covert smuggling. ${ }^{2}$ As such, this chapter will review Russia's ability to recover from sanctions, its capabilities that enable it to avoid sanctions as per Miyagawa's theory, and its additional capabilities that were developed from this research.

Notwithstanding the substantial sanctions that affected Russia immediately after their implementation, Russia's economy recovered for the most part after 2016 - and even some of its diplomatic standing. Following both Nephew's and Miyagawa's evaluations, target states will often do what is required in order to reject concessions and avoid sanctions. The most recent Iran case, that Nephews uses, showed how US sanctions on Iran's import of gasoline failed due to the

\footnotetext{
${ }^{1}$ Nephew, 85.

2 Nephew, 85.

Demyan Plakhov
} 
lack of appreciation for Iran's steadfast commitment to keeping cars on the road and its capability to employ unorthodox methods to resolve issues created by sanctions. ${ }^{3}$ Nephew and Miyagawa both show how extending and expanding sanctions increase the greater risk and uncertainty, while entrenching target states further into their original positions. In rejecting concessions, Russia also pursued efforts to avoid sanctions, recover, and to adapt to this 'new reality'. At his annual press conference on December 20, 2018, President Putin claimed that Russia is an "emerging, mighty and powerful" player, "one that must be reckoned with, even if [the West] does not want to". ${ }^{4}$ President Putin acknowledged that Russia first faced "some adverse effects," but emphasized that Russia switched its economic planning and, as a result, claimed that the "[Russian] economy has adapted to [sanctions]," and actually gained from the sanctions regime.

\subsection{Russia's Recovery From Sanctions}

Russia’s GDP increased by nearly $30 \%$ in two years from $\$ 1.283$ trillion (2016) to $\$ 1.658$ (2018) — closely mirroring global oil prices and its GNI. ${ }^{5}$ Russia's Real GDP growth decreased from $1.8 \%$ (2013) to $-2.3 \%$ (2015), but then recovered to $2.3 \%$ (2018) equivalent to the EU's

\footnotetext{
3 Nephew, 86.

4 Vesti News, "Western Food Sanctions Hit Russia Hard, Forced Domestic Industry to Expand, Grow and Adapt!" Russia: VGTRK, Youtube, January 27, 2019.

5 World Bank, “GDP (current US\$) - Russian Federation,” Based on World Bank, national data, and OECD National Accounts data, 2019; Macrotrends, "Crude Oil Prices - 70 Year Historical Chart," Based on West Texas Intermediate (WTI or NYMEX) crude oil prices per barrel, 2020;

World Bank, "GNI (current US\$) - Russian Federation," Based on World Bank, national data, and OECD National Accounts data, 2019;

Refer to Figure 3.1 in Appendix B.
} 
levels. ${ }^{6}$ Russia's FDI also initially decreased in 2015-2016, but then recovered in 2017 and 2018.7 In terms of trade, total exports first decreased from 2014 to 2016, but then steadily increased throughout 2017 to 2019 reaching above $\$ 35$ billion per month. ${ }^{8}$ Russia’s total export of goods went from $\$ 497.8$ billion annually (2014) to $\$ 301.8$ billion annually (2016), and then back up to $\$ 451.5$ billion annually (2018). ${ }^{9}$ While Russia’s imports of goods went from $\$ 286.6$ billion annually (2014) to $\$ 182.8$ billion annually (2015), and then up to $\$ 260$ billion annually (2017). ${ }^{10}$ Russia's trade in services also recovered for the most part, with imports starting at $\$ 118.7$ billion annually (2014), dropping to $\$ 72.5$ billion annually (2016), and then recovering back to $\$ 92$ billion annually (2018). ${ }^{11}$ Likewise, Russia's export of services also decreased from $\$ 62.5$ billion annually (2014) to $\$ 47.4$ billion annually (2016), and then recovered back to $\$ 61.3$ billion annually (2018).12 Figures 1-5 in Appendix B show further developments in Russia's main economic indicators.

\footnotetext{
6 International Monetary Fund, "Real GDP growth: Annual percent change," IMF DataMapper, April 2020; Refer to Figure 3.3 in Appendix B.

7 World Bank, "Foreign direct investment, net (BoP, current US\$) - Russian Federation,” Based on International Monetary Fund, Balance of Payments Statistics Yearbook and data files, 2019;

Refer to Figure 3.4 in Appendix B.

8 CEIC Data, "Russia Total Exports," Countries/Regions: Russia, 2020;

Refer to Figure 3.2 in Appendix B.

${ }_{9}$ Department for International Trade (DIT) and the Department for Business, Energy and Industrial Strategy (BEIS) of the United Kingdom. "Russian Federation trade in goods with World since 1996." Russian Federation exports of goods in 2018. Based on UN Comtrade data (2020).

10 Ibid.

11 Department for International Trade (DIT) and the Department for Business, Energy and Industrial Strategy (BEIS) of the United Kingdom. "Russian Federation trade in services with World since 2000." Russian Federation exports of goods in 2018. Based on UN Comtrade data (2020).

12 Ibid.
} 
Russia's oil exports increased by approximately $16 \%$ from 4,488 barrels per day (2014) to 5,080 barrels per day (2016) — and has remained above 5,000 barrels per day through 2016-18, equivalent to its 1988 and 2004-08 peak levels. ${ }^{13}$ Similarly, natural gas exports have also increased to unprecedented levels. Russia first experienced a $12.8 \%$ decrease from 2013 to 2014, but then consistently increased its exports each year, resulting in a near 30\% increase from 2014 to 2018 - higher than its 2006-08, 2011, and 2013 peaks. ${ }^{14}$ Continuing to look at Russia's energy industry, its oil production levels have been consistently increasing since 2000 , without a major impediment from sanctions thus far. ${ }^{15}$ In late 2018, Russia produced over 11,000 MBPD (thousands of barrels per day) - its highest ever level.16 Although Russian natural gas production went through a 5.4\% decrease from 2013 to 2015, it recovered from its fall in 2016 and actually grew by $15.2 \%$ to an unprecedented level of 690 billion cubic meters in $2018 .{ }^{17} \mathrm{In}$ addition, Russia continues to sell arms at a slightly higher than usual rate. Notwithstanding 2011-2013 as unusual years with outlier numbers as high as $\$ 8.7$ billion annually, between 2000 and 2010 Russia sold \$4.5-6.3 billion annually. ${ }^{18}$ After sanctions, Russia sold between \$5.4-6.7 billion annually. Therefore, from these observations, although Russia's trade and production were strained at first, they recovered and even achieved new heights in some sectors. Even with

\footnotetext{
${ }^{13}$ CEIC Data, "Russia Crude Oil: Exports,” Countries/Regions: Russia, 2020.

${ }^{14}$ CEIC Data, "Russia Natural Gas: Exports,” Countries/Regions: Russia, 2020.

15 CEIC Data, “Russia Crude Oil: Production,” Countries/Regions: Russia, 2020.

16 Ibid.

${ }_{17}$ CEIC Data, "Russia Natural Gas Production: OPEC: Marketed Production," Countries/Regions: Russia, 2020.

18 Stockhold International Peace Research Institute, “TIV of arms exports from Russia, 2000-2019," SIPRI Arms Transfers Database, Generated May 21, 2020.
} 
financial restrictions on its energy sector and an arms trade ban, Russia maintained its export and production levels in both sectors.

After sanctions, inflation rate was as high as $15.5 \%$ in 2015 when inflation was averaging around 7\% from 2010-2014.19 This rapidly decreased the value of the ruble (national currency), as prices of all goods increased. In addition, due to the relatively low average income of Russian citizens, rising prices are instantly felt. It also causes individuals to reduce their holdings in that currency, switching to more stable foreign currencies such as the USD, which further harms the Russian ruble. Nonetheless, Russia's inflation rate subsided to well under $8 \%$ after 2016, and even recorded 2.4\% in January 2019.20 Russia's net capital account recovered from a $\$ 42$ billion drop in $2014 . .^{21}$

Capital flow shows the amount of foreign funds being invested into Russia; a negative capital flow balance implies that the amount of investments leaving Russia for foreign sources is more than investments coming into Russia from foreign sources, which reinforces less demand for the Russian ruble and decreases its value further. Moreover, the outflow of capital combined with the lack of inflow of capital can severely damage a country's economic or GDP growth. However, after that initial decrease, Russia recovered almost immediately in 2015 and showed rising capital flows on average until at least the last quarter of 2019.

\footnotetext{
19 Russia's 2015 inflation rates equaled those of 2002;

World Bank, "Inflation, consumer prices (annual \%) - Russian Federation," Based on International Monetary Fund, International Financial Statistics and data files, 2019;

Refer to Figure 3.5 in Appendix B.

20 Ibid.

21 World Bank, "Net capital account (BoP, current US\$) - Russian Federation," Based on International Monetary Fund, Balance of Payments Statistics Yearbook and data files, 2019.
} 
Russia's government budget went from a $0.5 \%$ deficit of its GDP (2014) to an even higher deficit of $3.4 \%$ of its GDP (2016), and then recovered with a surplus of $2.9 \%$ of its GDP in 2018.22 This could be explained by Russia's dependence on energy and particularly energy exports - again, given that energy accounts for $47 \%$ of Russia's federal budget and $30 \%$ of its GDP. ${ }^{23}$ General government net lending (positive) or borrowing (negative) index is calculated as the difference between government revenue and expenditure, which could show if the Russian government is either lending or borrowing more on average. If the Russian government is net lending, then it is "putting financial resources at the disposal of other sectors in the economy and nonresidents," and if it is net borrowing, then it is "utilizing the financial resources generated by other sectors and nonresidents". ${ }^{24}$ In a tougher economic situation, the government might be forced to borrow since total revenue can decrease, and it can be an indicator of the "financial impact of general government activity on the rest of the economy and nonresidents". ${ }^{25}$ Additionally, Russian general government net lending/borrowing measure was decreasing since 2011, but substantially decreased after sanctions to $-3.7 \%$ of its GDP in $2016 .{ }^{26}$ However, Russia's index reversed in 2018, after its rapid increase, when it started lending at net percentage

\footnotetext{
22 The government budget is a great tool to evaluate Russia's ability to balance its revenues and spending: MINFIN Rossii, "Federalniy Byudzhet," Statistika, 2020.

${ }^{23}$ Martin Russell, "Sanctions over Ukraine: Impact on Russia,” EPRS | European Parliamentary Research Service, January 2018;

Greg Depersio, "How does the price of oil affect Russia's economy?" Investopedia, April 11, 2019;

Tsvetana Paraskova, "Russia's oil revenue is about to soar," Business Insider, May 14, 2018;

Statista Research Department, "Russian federal budget oil and gas revenue 2016-2019," Statista: Fossil Fuels, February 2020;

MINFIN Rossii, "Federalniy Byudzhet," Statistika, 2020.

${ }^{24}$ International Monetary Fund, "General government net lending/borrowing: Percent of GDP," IMF DataMapper, April 2020.

25 Ibid.

26 Ibid.
} 
of $2.9 \%$ of its GDP, and continued lending in 2019.27 Additionally, the Russian general government gross debt has remained the same, reaching just above $16 \%$ of GDP between 2014-2016, and then between 14-16\% of GDP in 2016-2018.28

With regards to the World Economic Forum's (WEF) Global Competitiveness Index, Russia has been uninterruptedly and consistently climbing through the rankings starting at 64th place (2014), then to 53rd (2015), and finally staying at 43rd from 2017 to present moment. ${ }^{29}$ WEF in 2016 noted that in the face of the 2014 currency crisis and rising inflation, Russia improved on its market efficiency, such as "regulatory business environment and domestic competition, reflecting the government's efforts to improve domestic conditions for doing business". ${ }^{30}$ One year later, the WEF followed up by stating that although Russia fell into its 2015 recession, it remained "rather stable in terms of its competitiveness," due to its improved innovation capacity, improved domestic business environment, and less negative domestic business sentiment than usual. ${ }^{31}$ According to the WEF and the IMF as of 2017, low government

27 International Monetary Fund, “General government net lending/borrowing: Percent of GDP," IMF DataMapper, April 2020.

${ }^{28}$ General government gross debt is a key indicator of a government's sustainable financing as it consists of liabilities requiring interest and/or principal payments by Russia to the creditor in the future, which includes Special Drawing Rights (SDRs), deposits, currency, debt securities, loans, insurance, pensions and standardized guarantee schemes, and other forms;

International Monetary Fund, "General government gross debt: Percent of GDP," IMF DataMapper, April 2020; Organisation for Economic Co-operation and Development, "General government debt: Total Percent of GDP," OECD Data, 2018.

29 The lower the ranking, the better the standing (\#1 is the best);

World Economic Forum, "The Global Competitiveness Report 2013-2014,” Insight Report: Full Data Edition, 2013;

World Economic Forum, "The Global Competitiveness Report 2014-2015,” Insight Report, 2014;

World Economic Forum, "The Global Competitiveness Report 2015-2016," Insight Report: Highlights, 2015;

World Economic Forum. "The Global Competitiveness Report 2016-2017." Insight Report. 2016;

World Economic Forum, "The Global Competitiveness Report 2018," Insight Report, 2017;

World Economic Forum. "The Global Competitiveness Report 2019.” Insight Report. 2018.

30 World Economic Forum, “The Global Competitiveness Report 2015-2016,” Insight Report, $2015: 30$.

31 World Economic Forum, “The Global Competitiveness Report 2016-2017,” Insight Report, $2016: 29$. 
debt, unchanged gross national savings, exchange rate flexibility, banking sector capital and liquidity injections, limited fiscal stimulus, and regulatory forbearance helped Russia "cushion the shocks $[\ldots$ and $]$ restore confidence and stabilized the financial system". 32 By 2018 , WEF confirmed Russia's increase in competitive performance due to better growth prospects, stabilization of its macroeconomic context, reduction of its inflation rate, maintenance of low government debt, leveraging its large market size, growing adoption of high-level of ICT (Information and Communication Technology), and utilizing human capital. ${ }^{33}$ In the most recent evaluation, published in 2019, the WEF concludes that Russia's macroeconomic environment had further improved, overcoming the effects of the 2015 recession, reducing inflation to as low as $3 \%$, maintaining sustainable public financing, and improving its innovation capability through increased research institutions and R\&D (research and development) expenditure. ${ }^{34}$

Russia has also recovered to some extent in the diplomatic sphere, as it successfully pivoted to secondary states and other markets, and built stronger bilateral ties with some sender states to undermine sanctions regime, while also being readmitted to the Council of Europe (with the support of France and Germany) and restarting G7 deliberations over readmission to the group, both of which occurred in the summer of 2019.35

\footnotetext{
32 World Economic Forum, “The Global Competitiveness Report 2016-2017,” Insight Report, $2016: 29$.

33 Ibid, 28.

34 World Economic Forum, “The Global Competitiveness Report 2019,” Insight Report, 2018: 18-19.

35 Gilbert Reilhac, "Council of Europe readmits Russia, five years after suspension over Crimea," Reuters: World News, June 25, 2019;

Julian Borger, "G7: Trump's demands for Russia's readmission cause row in Biarritz," The Guardian, August 25, 2019.
} 
Notwithstanding Russia's ability to adapt to sanctions and recover, its economy is still suffering from many issues such as lower inflow of capital, especially with respect to mineral revenues, quasi-closure of international financial markets to Russian entities, and reduced availability of loans and venture capital. ${ }^{36}$ Russia's financial system is still limited in depth such as insufficient access to finance, limiting competitiveness of Russian firms — which constraints investment required to achieve value chains with greater breadth and sophistication. ${ }^{37}$ More recently, WEF also pointed to Russia's weak entrepreneurial culture, limited interaction, and diversity substantially constraining its workforce potential, as well as its three weakest pillars: innovation, institutions, and transparency (including corruption). ${ }^{38}$

\subsection{Russia's Intent to Recover and Counter Sanctions}

Besides understanding how Russia has been able to adapt to sanctions, it is also necessary to establish its intent to do so since it could be argued that Russia was simply recovering from broad economic issues. Russia's intent to adapt to economic difficulties exacerbated by sanctions in the post-2014 circumstances was made clear by the National Economic Security Strategy adopted on May 15, 2017. ${ }^{39}$ Although the strategy was signed and publicly released in mid-2017, the decision to develop a new strategy to counter Russia's "economic security threats" was

\footnotetext{
36 World Economic Forum, “The Global Competitiveness Report 2016-2017,” Insight Report, 2016: 29.

37 World Economic Forum, “The Global Competitiveness Report 2019,” Insight Report, 2018: 19.

38 Ibid, 482-5.

39 Prezident Rossi, "Utverzhdena Strategiya ekonomicheskoy bezopasnosti Rossii do 2030 goda," Novosti:

Dokumenty, May 15, 2017. 
delivered at a Security Council of Russia meeting on July 3, 2015.40 President Putin held an extensive Security Council meeting where members deliberated on a "range of issues" concerning the "protection of Russia's security and national interests in the face of sanctions imposed by a number of countries". ${ }^{41}$ Stemming from this meeting, the National Economic Security Strategy depicts 'challenges and threats' to Russia's economic security and outlines the government's intention to counter those challenges and threats. ${ }^{42}$ The document lists two particular major threats to Russia's economic security: a) “the developed countries' desire to use their economic and high-tech development advantages as instruments in global competition," b) "the use of discriminatory measures against key sectors of the Russian economy". ${ }^{43}$ Although the strategy does not directly mention sender states or the West, it does ambiguously point to these nations and refers to the sanctions regime as the sender states' desire to counter Russia in global competition by using 'economic advantages' and 'discriminatory measures'. ${ }^{44}$ In the 2015 meeting, President Putin did not stop short of labelling sender states as "geopolitical opponents," and argued that these opponents will likely not change their "hostile course" against Russia due to "global rivalry".45 Furthermore, this exemplifies Russia's way of labelling the sanctions

\footnotetext{
40 The Security Council of Russia is not to be confused with the United Nations Security Council, since this security council is a Russian agency acting as a consultative body for the President of Russia on security matters:

TASS, "Putin approves Russian economic security strategy until 2030," TASS Russian News Agency, May $15,2017$.

41 Prezident Rossii, “Zasedaniye Soveta Bezopasnosti,” Novosti: Sobytiya, July 3, 2015.

42 TASS, "Putin approves Russian economic security strategy until 2030," TASS Russian News Agency, May 15, 2017.

43 Prezident Rossi, "Utverzhdena Strategiya ekonomicheskoy bezopasnosti Rossii do 2030 goda," Novosti:

Dokumenty, May 15, 2017.

44 Nigel Gould-Davies, "Russia’s Economic Security Strategy Has Become an Internal Critique," Chatham House: Expert Comment, June 20, 2017.

45 President of Russia, “Security Council meeting,” News: Events, July 3, 2015.
} 
regime as hostile using 'discriminatory measures' — which are usually protected under bilateral or multilateral investment treaties. ${ }^{46}$ For the Russian government, restrictive measures against key sectors of the Russian economy and restricted access to international financial resources are important economic challenges, and although President Putin affirmed that, he attempted to argue that they have also produced new opportunities for Russia.

According to the 2017 National Economic Security Strategy that will last until 2030, the Russian government believes that to ensure economic security and counter threats, Russia must: a) strengthen its economic sovereignty, b) bolster its economic resistance to internal and external threats, c) develop the national governance system, economic forecasting and strategic planning, d) develop human potential, and e) establish conditions for the development of modern technology. ${ }^{47}$ Following President Putin's emphasis on sanctions by reducing Russia's “dependence on negative external factors" in 2015, the National Economic Security Strategy of 2017 made sure to input Russia's most significant goal of "advancing retaliatory measures to fight sanctions". 48 The strategy also substantially emphasized the need to improve Russia's investment climate, de-offshorization, structural change, improve export capacity, develop a stronger financial system, and import substitution. ${ }^{49}$

\footnotetext{
46 United Nations Conference on Trade and Development, “Agreement on Partnership and Cooperation Establishing a Partnership between the European Communities and Their Member States, of One Part, and Russia, of the Other Part," International Investment Agreements Navigator: EC-Russia PCA, 2020.

47 Prezidentskaya Biblioteka, “O strategii ekonomicheskoy bezopasnosti Rossiyskoy Federatsii na period do 2030 goda," Ukaz Prezidenta Rossiyskoy Federatsii no. 208 (May 13, 2017).

48 Prezident Rossii, “Zasedaniye Soveta Bezopasnosti,” Novosti: Sobytiya, July 3, 2015;

TASS, "Putin approves Russian economic security strategy until 2030," TASS Russian News Agency, May 15, 2017.

49 World Economic Forum, “The Global Competitiveness Report 2018,” Insight Report. 2017: 28.
} 
Russia's counter-sanctions against the EU substantially changed the agricultural sector and supermarkets in Russia. Russia's counter-sanctions against the EU, called Executive Order on special economic measures to protect Russia's security, targeted dairy, vegetables, fruit, and fish imports. ${ }^{50}$ These measures directly decreased Russia's supermarkets' ability to provide basic foodstuffs, such as cheese, to the Russian public and created food shortages - correspondingly increasing the prices of food, which put the Russian public at an economic disadvantage when buying food. ${ }^{51}$ A study led by the Centre for Economic and Financial Research (CEFIR) and the Russian Presidential Academy of National Economy and Public Administration (RANPEA) in 2019 suggested that when comparing Russia's counter-sanction effects and its own import substitution for the past five years, Russians lost around $\$ 6.1$ billion annually (445 billion rubles) — or $\$ 41$ (3,000 rubles) per person. ${ }^{52}$ This might not seem like a substantial increase to an average Canadian income of $\$ 46,700$, but it will make a difference to an average Russian salary of just $\$ 8,616.53$ The reason for this maneuver by Russia could be that the government was attempting to trim imports in order to manage its export shortfalls — due to the major loss in oil sales that cost Russia $\$ 160$ billion. ${ }^{54}$ Managing its import and export levels also reduced Russia’s ruble depreciation. Consequently, Russia's counter-sanctions maneuver covered several key

\footnotetext{
${ }^{50}$ Prezident Rossii, "Ukaz o primenenii otdelnykh spetsualnykh ekonomicheskikh mer v tselyakh obespecheniya bezopasnosti Rossiyskoy Federatsii," Novosti: Sobytiya, August 6, 2014;

Roland Oliphant, "Russia introduces ban on most food imports from EU and US," The Telegraph, August 7, 2014.

${ }^{51}$ Kirill Zykov, “Putin’s Counter-Sanctions Cost Russians \$70 Per Person Every Year.” Moscow Times. October 29, 2019.

52 Aleksey Shapovalov, "Gordye platyat vsem," Kommersant, October 29, 2019.

${ }^{53}$ Statistics Canada, "Income of individuals by age group, sex and income source, Canada, provinces and selected census metropolitan areas," Government of Canada, May 21, 2020;

Moscow Times, "Half of Russians Say They'll Never Live to See a Decent Salary - Survey," Moscow Times, April $10,2019$.

${ }^{54}$ Nephew, 159-160.
} 
aspects since it: showed the West that Russia will not back down, enforced an asymmetrical response that would damage the European economy, balanced its imports with export shortcomings, reduced ruble depreciation, and incentivized investment into Russian domestic agriculture. 55

During the annual "Direct-Line" in 2017, President Putin affirmed this belief in stating that Russia historically has always been under some form of sanctions, and that the aims of sanctions do not matter since their 'actual' objective is to contain Russia from "standing up on its feet," to prevent it from becoming more involved in international politics. ${ }^{56} \mathrm{He}$ also specifically mentioned that even if there was no annexation of Crimea, the West would still find an excuse to implement sanctions against Russia. The Russian government completely disregards the official aims of EU's sanctions and reaffirms that Western sanctions against Russia is the 'normal,' leading to the fact that Russia perceives inevitable conflict with the West and that the official sanctions' aims are not the actual objectives which can be negotiated. In the same format, two years later, President Putin reaffirmed this position by stating that if Russia "completely surrenders and spits on [disregards] its own fundamental national interests" there might be minor changes from the West, but the major foreign policy towards Russia will not change. ${ }^{57}$ In the Russian government's perspective, as he dictates, the West sees Russia and China as competitors challenging its global power. As such, the West — particularly the US - will continue to

\footnotetext{
55 Judy Twigg, "Russia Is Winning the Sanctions Game,” The National Interest, March 14, 2019.

${ }^{56}$ RUPTLY, "Russia: Stricter anti-Russia sanctions introduced 'to contain' Russia - Putin," Russia: RT, Youtube, June $15,2017$.

${ }^{57}$ RUPTLY, “Russia: Putin discusses sanctions, Trump's Huawei ban at 'Direct Line'," Russia: RT, Youtube, June 20, 2019.
} 
suppress Russia from becoming a global power through various means, including sanctions. President Putin concludes that, as a result of this, Russia must become "stronger, especially in terms of its economic posturing," to gain a "spot under the sun". Moreover, these statements exemplify the Russian government's messaging that Russian concessions to sanctions, no matter how small, would equal to a 'surrender' to the West, which would be monumentally against Russian national interests and national pride, and would therefore be unacceptable. Respectively, Nephew commented on the significance of sanction objectives, noting that imposing sanctions upon a target state is "sheer sadism" unless they are directly linked to (an) expectation(s) on what the target state needs to do to remove those sanctions..$^{58}$ Therefore, based on this consideration, Russia's perspective in believing that the EU and other sender states are subjecting Russia to sanctions without reason and/or would subject Russia to sanctions utilizing any excuse for the sole purpose of imposing sanctions, would suggest that Russia believes that the EU and other sender states are "sadistic" in their imposition of sanctions.

The EU's European Parliamentary Research Service (EPRS) January 2018 briefing also showed how Russians were avoiding sanctions on an individual basis, understanding that the Russian government would not change its foreign policy. The briefing noted that sanctions have had a "limited impact" on individuals subject to these sanctions, even with EU and US travel bans and asset freezes. ${ }^{59}$ For instance, even though Arkady Rotenberg lost access to approximately \$65 million in the US and \$32.6 million in Italy, while Gennady Timchenko lost a

\footnotetext{
58 Nephew, 48.

59 Russell, "Sanctions over Ukraine: Impact on Russia," EPRS | European Parliamentary Research Service, January 2018: 6 .
} 
43\% stake in Gunvor, an oil-trading company, both Rotenberg and Timchenko have since been adequately reimbursed through "lucrative government contracts". 60

\subsection{Miyagawa's Conditions}

Utilizing Miyagawa's theoretical framework, this section will outline the seven conditions to help explain how Russia was able to recover and adapt to sanctions including: a) dependence on trade, b) size of the economy, c) specific trade partners, d) availability of substitutes, e) foreign exchange reserves, f) monitoring via blockades, and g) economic system. ${ }^{61}$ It is important to note, however, that even Miyagawa pointed out cases where sanctions were unsuccessful despite meeting some or most of these conditions, such as the 1935 League of Nations' sanctions against Italy over the invasion of Ethiopia or the US, UK and others' sanctions against Japan in 1939-1941 over its expansionist foreign policy or the 1948-53 USSR sanctions against Yugoslavia, the 1960 US sanctions against Cuba, and the 1966-68 UN sanctions against Rhodesia. ${ }^{62}$ Table 3.1 in Appendix A reviews these components.

The first component of Miyagawa's theoretical framework hypothesizes that there is greater economic impact if the target's domestic economy relies on foreign trade — consequently a self-sufficient economy would be immune to sanctions, while a country reliant on importing vital raw materials and energy would be more vulnerable. ${ }^{63}$ In a July 2015 Security Council

\footnotetext{
${ }^{60}$ Russell, 6.

${ }^{61}$ Miyagawa, 24-28.

62 Miyagawa, 49-54.

${ }^{63}$ Miyagawa, 24.
}

Demyan Plakhov 
meeting, President Putin declared that Russia will support import substitution projects especially in agriculture, defence, engineering, pharmaceuticals, and chemicals sectors - thereby, promoting importzamesheniye or import substitution industrialization (ISI). ${ }^{64}$ ISI is an economic policy that attempts to replace foreign imports with domestic production, usually pursued by developing countries or emerging-market nations seeking to reduce their dependence on developed countries. ${ }^{65}$ This was implemented by Russia with a ban on agricultural imports, state procurement with a particular focus on the agricultural sector, state programs for business loans, and supporting business alliances. ISI may increase employment and support local producers in the short term, but in the long term ISI policies can limit both output and growth of those industries and the national economy, increase the risk of path-dependence, lead to inefficient industries, become more costly than trading, and lose resources devoted to mechanisms monitoring and implementing the strategy. ${ }^{66}$ Nevertheless, for Russia the case is different since it did not rely on an ISI strategy alone but used it in combination with other capacities. ${ }^{67}$ Russia's implementation of a quasi-ISI approach boosted its agricultural sector to be one of the fastest growing segments of the economy, becoming the world's largest exporter of wheat, second

\footnotetext{
${ }^{64}$ Prezident Rossii, “Zasedaniye Soveta Bezopasnosti,” Novosti: Sobytiya, July 3, 2015; Importzamesheniye (Импортозамещение) also known as import substitution industrialization (ISI).

65 Troy Segal, “Import Substitution Industrialization - ISI,” Investopedia, April 11, 2019.

${ }^{66}$ Sebastian Galiani and Paulo Somaini, "Path-dependent import-substitution policies: the case of Argentina in the twentieth century," Latin American Economic Review 27, no. 5 (2018);

Tirthankar Roy, "The Origins of Import Substituting Industrialization in India," Economic History of Developing Regions 32, no. 1 (2017): 71-95.

${ }^{67}$ Aregbeshola R. Adewale, "Import substitution industrialisation and economic growth - Evidence from the group of BRICS countries," Future Business Journal 3, no. 2 (2017): 138-158.
} 
largest producer of sunflower seeds, third largest producer of potatoes and milk, and fifth largest producer of eggs and chicken meat. ${ }^{68}$

For the second component, the smaller the target state's economy and the larger the sender states' is by GNI, the more likely sanctions are to be effective. ${ }^{69} \mathrm{~A}$ small GNI can be an indicator of a small economic surplus that should limit the target state's economic flexibility in allocating resources to resist sanctions. Russia's GNI is dwarfed by the size of its sender states, even when completing a one-on-one comparison between Russia-US and Russia-EU.70 Russia's GNI comes to approximately $\$ 1.6$ trillion (2018), while the US' measures at $\$ 20.8$ trillion (2018) and the EU's at $\$ 18.8$ trillion (2018). ${ }^{71}$ Nonetheless, Russia does not have a small GNI since it is the 12th largest globally and on par with some G7 nations, which allows it the economic flexibility necessary to allocate resources as seen in the aforementioned component with respect to its quasi-ISI strategy. This is especially evident when comparing Russia's GNI to other nations

\footnotetext{
${ }^{68}$ Russia's quasi-ISI approach utilizes aspects of the ISI with a few sectors, and not with all import sectors. Russia applies ISI measures only to sectors affected by sanctions; Aregbeshola R. Adewale, "Import substitution industrialisation and economic growth - Evidence from the group of BRICS countries," Future Business Journal 3, no. 2 (2017): 143; USDA Foreign Agricultural Service, "Russian Federation: Agricultural Economy and Policy Report," Global Agricultural Information Network, GAIN Report Number: RS1819, July 19, 2018.

${ }^{69}$ Miyagawa, 24;

The GNI is the total value of the output of all final products and services by means of production owned by the country's residents, which includes private domestic investment, personal consumption expenditures, net exports, and government expenditure. More information can be found here:

Jim Chappelow, “Gross National Product (GNP)," Investopedia: Macroeconomics, March 20, 2020.

${ }^{70}$ Refer to Figure 3.7 in Appendix B.

71 World Bank, "GNI (current US\$) - Russian Federation, United States, European Union," Based on World Bank, national data, and OECD National Accounts data, 2019;

Refer to Figure 3.6 in Appendix B.
} 
that the EU has recently sanctioned including Iran (\$454 billion), Egypt (\$244 billion), Myanmar (\$69), Libya (\$49 billion), and Sudan (\$37 billion). ${ }^{72}$

The third component dictates that the more the target state's trade is intertwined with specific partners, especially when they also impose sanctions, the more vulnerable it is to sanctions. This component is clearly present as the EU-Russian trade is well intertwined. Even with sanctions in place, EU is the largest trading partner for Russia amounting to approximately 253 billion euros, $36 \%$ of Russia's total trade. ${ }^{73}$ This trade is particularly important for Russia due to its dependence on selling energy products to the EU. This is especially evident when considering that a few EU members (Netherlands, Germany, Poland, Italy, and Finland) account for most of Russia's energy exports valuing nearly $\$ 80$ billion. ${ }^{74}$ However, with this existing energy trade vulnerability for Russia, the EU has yet to place trade restrictions on this sector due to its energy interdependency on Russia. In addition, Russia increased its trade in goods with China with $\$ 108.2$ billion trade $(15.6 \%$ of Russia's total trade) and South Korea with $\$ 24.8$ billion trade (3.5\% of Russia's total trade), as the EU has yet to place any secondary sanctions. ${ }^{75}$

\footnotetext{
72 World Bank, “GNI (current US\$) - Iran, Islamic Rep., Sudan, Venezuela, RB, Myanmar, Egypt, Arab Rep., Tunisia, Libya," Based on World Bank, national data, and OECD National Accounts data, 2019;

Refer to Figure 3.6 in Appendix B.

73 European Commission. "Trade Picture." Countries and regions: Russia. May 20, 2020; Postoyannoe predstavitelstvo Rossyskoy Federatsii pri Evropeyskom soyuze, "Torgovlya," Kratkiy obzor otnosheniy: Sfery sotrudnichestva, 2020.
}

74 Department for International Trade (DIT) and the Department for Business, Energy and Industrial Strategy (BEIS) of the United Kingdom, "Russian Federation - Top-10 export markets for Nuclear reactors, boilers, machinery, etc in 2018," Russian Federation exports of Nuclear reactors, boilers, machinery, etc in 2018, Based on UN Comtrade data (2020).

75 Department for International Trade (DIT) and the Department for Business, Energy and Industrial Strategy (BEIS) of the United Kingdom, "Russian Federation trade in goods with China since 1996," Russian Federation exports of goods in 2018, Based on UN Comtrade data (2020);

Department for International Trade (DIT) and the Department for Business, Energy and Industrial Strategy (BEIS) of the United Kingdom, "Russian Federation trade in goods with Republic of Korea since 1996," Russian Federation exports of goods in 2018, Based on UN Comtrade data (2020). 
In order to avoid this vulnerability, Russia has paradoxically increased energy trade with some EU members to increase their dependence on Russia, while also enacting a quasi-ISI strategy to 'bolster its sovereignty' and limit its dependence on certain foreign imports and pivoting to secondary states.

The fourth component to making sanctions more effective requires a level of difficulty for the target state to secure alternative foreign sources of supply, alternative markets, or substitutes for goods previously imported. ${ }^{76}$ As seen from the first component, Russia has done well to adapt via quasi-ISI policies and rapid increase in domestic production. Russia has also secured alternative markets and secondary states for both imports and exports, by pivoting in many respects to China, promoting the development of CIS (Commonwealth of Independent States) economic integration, and supporting the expansion of economic ties with the Shanghai Cooperation Organization (SCO) and the BRICS group (Brazil, Russia, India, China, and South Africa). ${ }^{77}$ Western sanctions against Russia and US tariffs against China have brought the two together as "strategic partners," consequently fortifying political, economic, and military ties. ${ }^{78}$ Besides increasing joint military exercises in recent years, China and Russia have increased total trade to an all-time high, rising by $70.4 \%$ from 2015 to 2018.79 On June 5, 2019, during the 70 th anniversary of the China-Russia diplomatic relationship, President Putin and China's President

\footnotetext{
76 Miyagawa, 25.

77 Prezident Rossii, “Zasedaniye Soveta Bezopasnosti,” Novosti: Sobytiya, July 3, 2015.

${ }^{78}$ It is also important to note the asymmetric economic relation between China and Russia, since China is Russia's second most important trading partner, but Russia is relatively small trading partner for China. Although there is an interest in developing relations, it is still fairly recent;

Jeronim Perović and Benno Zogg, "Russia and China: The Potential of Their Partnership," Center for Security Studies: Analyses in Security Policy no. 250 (October 2019).

${ }^{79}$ Holly Ellyatt, "Russia conducts massive military drills with China, sending a message to the West," CNBC: Defense, September 16, 2019.
} 
Xi Jinping agreed on formalizing their strategic partnership with the objective of doubling trade to $\$ 200$ billion by $2024 .{ }^{80}$ The two countries signed a 30 -year gas agreement worth $\$ 400$ billion, and several arms deals. ${ }^{81}$

The fifth component that could increase sanction effectiveness is if the target state's foreign exchange reserves (FOREX) are small, as the target state would find itself constrained by the lack of purchasing capacity to buy what it needs particularly in a crisis situation. ${ }^{82}$ The EU has tried to reduce Russia's FOREX through financial restrictions, particularly ones that limit loans and credit to Russian individuals and entities. ${ }^{83}$ Plus, several prominent Russian businessmen and oligarchs have sold their stocks and holdings in various companies, as a symptom of this component. After sanctions, Russia's FOREX decreased substantially from $\$ 500-550$ billion (2011-14) to $\$ 350-400$ billion (2014-18). However, after 2016, Russia began to steadily recover and increase its FOREX once again, reaching a new high of $\$ 562$ billion in

${ }^{80}$ Liangyu, "China, Russia agree to upgrade relations for new era," Xinhua, June 6, 2019;

Holly Ellyatt, "Are Russia and China the best of friends now? It's complicated, analysts say," CNBC: World Politics, September 27, 2019.

${ }^{81}$ Alec Luhn, "Russia signs 30-year deal worth $\$ 400$ bn to deliver gas to China," The Guardian, May 21, 2014; Russell, "Sanctions over Ukraine: Impact on Russia," EPRS | European Parliamentary Research Service, January 2018.

82 Miyagawa, 25.

${ }^{83}$ Council of the European Union, "Concerning restrictive measures in respect of actions undermining or threatening the territorial integrity, sovereignty and independence of Ukraine," Council Decision 2014/145/CFSP, EUR-Lex Publications office, September 14, 2019. 
January 2020.84 Moreover, Russia's FOREX is consistently in the top five in world by total sum — larger than the US (\$129 billion). ${ }^{85}$

The sixth criteria states that the easier it is for sender states to implement 'monitoring' measures - more accurately defined as ensuring restrictive measures through trade prevention such as various forms of possible blockades - then sanction effectiveness becomes more likely. ${ }^{86}$ This type of monitoring includes both the target state and secondary actors that may be undermining sanction effectiveness, which aims to control the target's trade relations with other nations by means of no-fly zones, naval, and/or land blockades. These actions might seem outdated, but they occurred recently and continue to be in use today with well-known examples including: the 1982 Falkland Islands blockade by the UK, the 1990 UN-authorized sea and air blockade of Iraq, the 1990 Soviet Blockade of Lithuania, the 1993-96 NATO blockade in Yugoslavia, and the ongoing Israeli-Palestinian blockades. Russia is not an island state, a landlocked country, or surrounded by impenetrable terrain such as mountain ranges or desert, nor is it lacking in substantial area or military power. In addition, Russia's secondary trading partners have well-established trade corridors like its lengthy land border with China, Venezuela's maritime access, or its well-established land borders with CIS members. At the same time, Russia does have some potential vulnerabilities, which may be exploited through the GUIK gap, the Baltic Sea, Gulf of Finland, the Øresund Strait, the Strait of Gibraltar, the Strait of Dover, the

\footnotetext{
${ }^{84}$ Bank Rossii, “Mezhdunarodnye rezervy Rossiyskoy Federatsii,” Bazy dannykh, May 1, 2020.

${ }^{85}$ It also important to note that the reserves also depend on the global price of oil, which is an indicator of how volatile reserves are and not sustainable in the long term. It also shows Russia's strong dependence on the profitability of its energy sector;

Elvis Picardo, "10 Countries with the Biggest Forex Reserves," Investopedia: FOREX Trading Strategy and Education, March 7, 2020.
}

${ }^{86}$ Miyagawa, 25. 
Black Sea, or the Bosporus strait (Appendix B). ${ }^{87}$ In spite of these possibilities, the EU and other sender states have not pursued this component. The EU does not hold a unified military force, and so this action would need to be coordinated on a member-state level or through a NATO military force.

The seventh and final component shows that sanctions are less effective with statetrading countries than with state's maintaining a free enterprise system where foreign trade is largely carried out by the private sector ${ }^{88} \mathrm{~A}$ free enterprise system is more prone to create opposition from private enterprises and pressure the government to change its policy, while statetrading countries are less vulnerable to this. Since the majority of Russia's major companies and trade occurs through state-owned channels, this component also enables Russia to avoid pressure from private enterprises and more effectively adapt to sanctions. ${ }^{89}$ The most recent 2019 IMF working paper on Russia's state footprint in the private sector reveals that, "its economic footprint remains significant [ ... increasing] from about 32\% of GDP in 2012 to $33 \%$ in 2016 [... while its] deep state footprint is reflected in a relatively high state share in formal sector activity (close to 40\%) and formal sector employment (about 50\%)". ${ }^{90}$ Observing the Freedom Index by Freedom House, freedom in Russia's private sector is one of its lowest scores due to the government's control over key industries. ${ }^{91}$ Therefore, the Russian government is able to

\footnotetext{
${ }^{87}$ Refer to Figure 3.8 in Appendix B.

88 Miyagawa, 25.

${ }^{89}$ Andrei Kolesnikov and Denis Volkov, "Pragmatic Paternalism: The Russian Public and the Private Sector," Russian Domestic Politics and Political Institutions | Russian Ideology, Carnegie Moscow Center, January 18, 2019.

90 Gabriel Di Bella, Oksana Dynnikova and Slavi Slavov, "The Russian State's Size and its Footprint: Have They Increased?" IMF Working Paper, International Monetary Fund, March 8, 2019.

${ }^{91}$ Freedom House, "Russia," Freedom in the World 2020, 2020.
} 
partially take on a central planning approach in terms of its national economy and trading policies, as seen by the National Economic Security Strategy. ${ }^{92}$

Altogether, all of Miyagawa's seven conditions help explain how Russia, as a target state, is able to avoid, absorb, and build resolve to sanctions. In addition to the EU and sender states' strategy limitations, Russia's capacities and circumstances also add to its ability to find resolve. In this section, it is evident that Russia has the ability to replace imports by looking to other actors, and by enhancing self-sufficiency through a quasi-ISI approach due to its substantial domestic resources. Its large economy — the 12th largest globally by GNI — and foreign exchange reserves provides Russia with economic flexibility. Russia's strong trade interdependence with the EU restricts sender states from utilizing its strongest vulnerabilities, while Russia's strong trade with other partners and the ability to secure alternative foreign sources of supply allows it considerable trade flexibility. Furthermore, the limited "blockade" possibilities as well as the Russian government's ability to maintain meaningful control over trade and national economic planning, as opposed to a free enterprise system, has also shown how Russia's capacity both restricts the sanctions regime and enhances its ability to find resolve.

\subsection{Additional Conditions}

Although Miyagawa's conditions clearly show how Russia's capacity and circumstances restrict sender states' sanctions and enhance Russia's ability to achieve resolve, there are several other conditions that could be outlined to further explain Russia's capacity. This case shows how

\footnotetext{
92 Prezident Rossii, "Utverzhdena Strategiya ekonomicheskoy bezopasnosti Rossii do 2030 goda," Novosti: Dokumenty, May 15, 2017. 
sanctions situations are different from case to case, since there are additional conditions and circumstances that may arise for certain nations, such as Russia. This section will list three additional conditions that will help elaborate on Russia's particular advantageous position including: a) its diplomatic influence through the United Nations Security Council and in other means, b) its nuclear and military capacity, and c) its lack of democratic governance and domestic influence of government through the press, religion, and other means.

The first additional component hypothesizes that the more diplomatic influence the target state has, the more ability it has to constrain sanctions and avoid, rendering them less effective - likewise, the greater the diplomatic influence of the sender state(s), the great likelihood of sanction effectiveness. Russia's particular case exemplifies a number of key diplomatic factors that enable its ability to restrict sanctions. First, and most importantly, it is a UNSC permanent member. Meaning that not only it is always a part of the council, but it also has veto power over any key resolution that are passed in the council. Therefore, while Russia is a UNSC P5 member, UN-authorized sanctions, blockades, or any other action against Russia or its strategic interests are impossible as it would veto any such resolution. ${ }^{93}$ Further, this position also leverages Russia to negotiate on other key issues, veto key proposals for additional leverage, and enables Russia the possibility of negotiating certain terms in exchange for its vote. In a different sphere, Russia is also able to utilize its strong bilateral relations to undermine sender states and to draw secondary actors to its side. For the former, Russia utilizes its political and economic means to undermine sender states by regularly conducting bilateral interactions with EU member states to

\footnotetext{
93 This includes any UNSC case referral to the International Criminal Court (ICC) related to crimes of aggression, as per Article 15 of the Rome Statute:

International Criminal Court, Rome Statute of the International Criminal Court, A/CONF.183/9, July 17, 1998.
} 
build direct relationships and to leverage economic ties, as was the case with the French President Emmanuel Macron over shared history and business ties, German Chancellor Angela Merkel over Nord Stream II and natural gas trade, and with Austria's Chancellor Sebastien Kurz over increasing natural gas trade. ${ }^{94}$ Its influence in the Council of Europe restored its voting power, since its financial contributions make up $9 \%$ of the council's budget. 95

The second additional component hypothesizes that the larger the nuclear and/or military capacity of the target state is, the more likely it is to prevent sender states from pursuing more effective sanctions policy - likewise, if sender states do not have nuclear and/or military capacity, then they are less likely to have an effective sanctions policy. Since effective sanctions policy must follow as part of a larger policy framework, not having the necessary additional hard power components such as nuclear and military capabilities or facing a target state with such capabilities makes it more difficult to pressure, leverage, and negotiate. Russia holds the highest amount of warheads with approximately 6,500 total warheads — with a vast arsenal of both strategic and tactical nuclear weapons, and the full nuclear triad made up of intercontinental ballistic missiles, submarine-launched ballistic missiles, and nuclear bombers. ${ }^{96}$ When addressing the Russian Federal Assembly on March 1, 2018, President Putin announced new innovative nuclear weapons, such as Avangard, Kinzhal, Sarmat, Burevestnik, Poseidon, and

\footnotetext{
94 Euronews (in English), "Live | French President Emmanuel Macron hosts Russia's Vladimir Putin for a visit," France: Euronews, Youtube, August 19, 2019;

UATV English, "Merkel-Putin Meeting: Ukraine, Nord Stream 2, Syria on the Agenda," Ukraine: UATV, Youtube. August 19, 2018;

AP Archive, "Putin on Russia natural gas supplies, Syria humanitarian assistance," AP, Youtube, June 10, 2018.

${ }_{95}$ Mikhail Bushuev and Elena Barysheva,"Russia in the Council of Europe: What does it mean for human rights?" DW: Europe, June 26, 2019.

96 Stockholm International Peace Research Institute, “Chapter 6: World nuclear forces,” SIPRI Yearbook 2019 , Oxford University Press, 2019.
} 
Peresvet, threatening to defend Russia's strategic interests through its nuclear capabilities. ${ }^{97}$ Additionally, Russia has one of the most extensive military capabilities including substantial land, air, sea, and special forces — spending around $\$ 61.4$ billion (3.7\% of its GDP), amounting to the sixth highest military expenditure in the world in 2018.98 This means that Russia would be able to confront any forces, including blockades, and could risk escalation of military confrontation. On the other hand, the EU does not have a unified army and relies on NATO, and individual member states for military posturing.

The third and final additional component speculates that if the target state lacks democratic governance and the target state's government maintains substantial domestic influence through the press, religion, and/or other means, it is more likely to avoid internal pressure to change its policy. Although Miyagawa attempts to affix this with his 'economic system' component, it is distinctly different from his component. Miyagawa tries to argue that, “in most cases state-trading states are also able to exercise firm control of public opinion, and this, too, reduces their vulnerability to economic sanctions". ${ }^{99}$ Even though Miyagawa's point may be correct, it is necessary to review this as a distinct factor as it is a separate measure. Assuming that most state-trading states may be able to apply domestic influence, the application is not always present and will also vary in degree on case-by-case basis. As per EPRS' 2018 report, "the more democratic a country, the greater the influence of sanctions," since sanctions can inconvenience the target state's general population or elite who can then pressure the

\footnotetext{
97 Prezident Rossii, "Poslanie Prezidenta Federalnomu Sobraniyu,” Novosti: Sobytiya, March 1, 2018. 98 Stockholm International Peace Research Institute, "V 2018 Godu Mirovye Voennye Raskhody Vyrosli do \$1.8 trln.” Press release, April 29, 2019.

99 Miyagawa, 26.
} 
government to change its policy or make concessions. ${ }^{100}$ Authoritarian regimes, like Russia — as per the Economist's 2019 Democracy index — do not allow public expression of discontent over the effect of sanctions or to influence government policy. ${ }^{101}$ Russian-state media continuously circulated the message that Western sanctions are harmful and costly, but no matter the cost, Russia would be always able to survive any sanctions - using misleading headlines like "Western food sanctions hit Russia hard, forced domestic industry to expand, grow and adapt," when Western sanctions did not include agricultural trade restrictions and were actually applied by the Russian government. ${ }^{102}$

Based on 2015 data, the three main TV channels broadcasting from Moscow - Perviy Kanal, Rossiya-1, and NTV — that are allegedly under strict control of the Russian government and follow rigorous self-censorship, cover $80-90 \%$ of Russian audiences with at least half of the respondents stating that they trust this type of television news the most. ${ }^{103}$ Directly speaking to the conflict in Ukraine, in comparison to one third of the surveyed population (mostly youth) $75 \%$ confirmed that they receive information on Ukraine from "government TV channels". 104 The virtual government monopoly over this type of information has given the Russian government the chance to craft its population's perceptions and to maintain its popularity, even

\footnotetext{
${ }^{100}$ Martin Russell,“EU sanctions: A key foreign and security policy instrument," EPRS | European Parliamentary Research Service, May 2018: 10.

101 Economist, “Global Democracy Index 2019," Infographic, 2019.

102 Vesti News, "Western Food Sanctions Hit Russia Hard, Forced Domestic Industry to Expand, Grow and Adapt!" Russia: VGTRK, Youtube, January 27, 2019.

103 Alexey Levinson, "Public opinion and propaganda in Russia," European Council on Foreign Relations, July 28, 2015.

104 Ibid.
} 
with sanctions imposed against the country. ${ }^{105}$ Moreover, sanctions had a 'rally round the flag' effect where the population has rallied behind its state leaders, perceived as 'defenders of the country' against Western hostility, rather than calling for policy change. ${ }^{106}$ A 2017 Levada poll showed that despite popular discontent with the national economic issues aggravated by sanctions, $70 \%$ of Russians still want their government to continue its foreign policy, regardless of sanctions. 107

Given that well over half of all Russians are affiliated with the Orthodox religion some research saying as high as $72 \%$ — the Russian Orthodox Church has tremendous and increasing influence with the Russian population. ${ }^{108}$ The church's deepening of relations with the Russian state is evident from its growing domestic influence, presence throughout government proceedings including the Federal Assembly, unprecedented blessing of the Russian President after inauguration, and President Putin and Patriarch Kirill's joint statement in 2019 on strengthening cooperation between state and the Russian Orthodox Church. ${ }^{109}$ According to Sergei Chapnin, former editor of the official journal of the Moscow Patriarchate, "the church has

\footnotetext{
105 Moscow Times, "State TV Still Biggest and Most Trusted News Source for Russians — Poll," Moscow Times, April 18, 2018.

106 Timothy Frye, "Do Economic Sanctions Cause a Rally around the Flag?" Center on Global Energy Policy, Columbia | SIPA, August, 3, 2017.

107 Levada-Tsentr, "Mezhdunarodnye otnosheniya i sanktsii," Ot mneniy - $k$ ponimaniyu, Press release. June 15, 2017.

108 Pew Research Center, "Russians Return to Religion, But Not to Church,” Religion \& Public Life, February 10 , 2014;

Hugh Seton-Watson, Andrew B. Wachtel, et al. "Religion.” Russia. In Encyclopedia Britannica. May 16, 2020.

109 Russia Insight, "Putin Gets Blessed By Head Of Russian Orthodox Church Kirill After Presidential Inauguration," Russia: Rossiya 24, Youtube, May 7, 2018;

Russian Orthodox Church, "Orthodox Patriarch of Moscow blesses President Putin,” Russia: Pravaslavnaya Tserkov, Youtube, May 7, 2018;

Vesti News, “'We Must Protect Our Identity” - Putin Declares Russia Will Pursue Closer Ties With Orthodox Church," Russia: Rossiya 1, Youtube, February 2, 2019.
} 
become an instrument of the Russian state. It is used to extend and legitimize the interests of the Kremlin". ${ }^{110}$ As a result, Patriarch Kirill's remarks on Russian state-owned channels may well influence the opinion of the domestic population through religion. With a nearly identical script delivered on both December 5, 2015, and February 15, 2020, Patriarch Kirill preached that Russia's revival is based on its economic recovery, and that if not for external interference referring to the West - Russia is capable and destined for revival due to its natural wealth and the abilities of the Russian people — instilling patriotism. He added in his address that Russia will still develop even if sender states place sanctions, and that in the future, "God willing, Russia ought to cease its dependence on foreign supplies, including food and medicine, to ensure its national sovereignty," concluding that, "Russia can be the one to preserve the human race from the total domination of evil". ${ }^{111}$ These types of remarks and preaching can help influence the population's opinion on sanctions through religion, to enhance not only Russian patriotism but to also induce anti-Western sentiment.

\footnotetext{
110 Committee on Foreign Relations United States Senate, "Putin's Asymmetric Assault on Democracy in Russia and Europe: Implications for U.S. National Security," A Minority Staff Report, U.S. Government Publishing Office, January 10, 2018: 53.

111 Perviy Kanal, “Slovo pastyrya. Efir ot 15 fevralya 2020 goda. Izbrannoe,” Russia: Perviy Kanal, Youtube, February 15, 2020;

Ruskaya Pravoslavnaya Tserkov, "Slovo pastyrya'. Vypusk ot 5 dekabrya 2015 goda," Programma "Slovo pastyrya, ” December 8, 2015.
} 


\section{Chapter 4: Inadvertent Effects of Sanctions}

\subsection{Introduction to Inadvertent Effects}

Not only did Russia not concede or attempt to meet the aims of EU's sanctions, it shifted away from those aims by reinforcing its existing foreign policy and by pursuing more foreign adventurism against sender state interests — resulting in inadvertent effects. ${ }^{1}$ This chapter will review Russia's actions, which will indicate that Russia has shifted away from sanctions' aims and how these actions confront the interests of sender states. However, even by indicating these actions, it does not necessarily suggest that sanctions were the reason for Russia's responses. To understand Russia's actions as a response to sanctions, it is also necessary to indicate Russia's intent to carry out asymmetrical actions as a direct response to sanctions.

Therefore, to establish Russia's actions as inadvertent effects to sanctions, this paper will first outline Russia's publicly-stated intent of applying asymmetrical responses due to sanctions. This paper will utilize Russia's official statements to establish intent, similar to earlier methods used in establishing EU's sanction aims in Chapter 2 and Russia's intents to adapt to sanctions in

${ }^{1}$ This paper defines foreign adventurism as the taking of excessive political and economic risks, in the absence or in defiance of accepted international regulations and/or principles.

For more on this term, please refer to:

Walt Schubert, "Peace defense," Forum for Social Economics 12, no. 1 (1982): 23-47;

James D. Fearon, "Domestic Politics, Foreign Policy, and Theories of International Relations," Annual Review of Political Science 1 (June 1998): 289-313. 
Chapter 3. It is also important to note that this thesis does not argue that sanctions are the solitary factor provoking Russia to pursue these reactions. This thesis suggests that sanctions have played an important role, along with other factors, in exacerbating tensions between the West (including the EU) and Russia, and acted as an additional key aspect that provoked Russia to react in the post-2014 order. Afterwards, this chapter will outline four key ways that sanctions have created inadvertent effects that have harmed sender states' interests and the effectiveness of their sanctions regime. Sanctions have inadvertently: i) entrenched Russia further into its original foreign policy, and provoked counter measures against sender states, ii) Russia reinforced its ties with Western adversaries, inducing more Russian involvement in other key regions, iii) Russia attempted to undermine sender states and their alliances, and iv) the Russian government was able to increase its domestic popularity and anti-Western sentiment.

\subsection{Russia's Intent to Counter Sanctions with Responses}

In a joint-press conference with Slovenia's former Prime Minister Miro Cerar on July 17, 2015, Russia's former Prime Minister Dmitriy Medvedev remarked on the nature of sanctions stating that they, "have never ended in anything good, and is harmful for development and business in Russia and Slovenia". ${ }^{2}$ Russian officials began to increase warnings and expand on Russia's threats. This was evident when three years later, on August 10, 2018, Medvedev issued a warning against further escalating sanctions stating that Russia views it as a declaration of "economic war", and threatened a Russian reaction directly to sanctions by further stating, "to

\footnotetext{
2 RUPTLY, "Slovenia: Sanctions have 'negative impact' on EU and Russia - PM Cerar tells Medvedev," Russia: RT, Youtube, July 27, 2015.
} 
that war we will definitely have to react - with economic means, political means, and if necessary also with other means". ${ }^{3}$ Although being ambiguous at some points, Russian officials have expanded 'other means' to include nuclear, military, and hybrid (or asymmetrical) threats. ${ }^{4}$ Overall, Russia's warnings have been consistent and threats have been escalating, signaling to the West that economic sanctions are not beneficial to anyone, that they should not invoke sanctions, and that Russia will react by utilizing asymmetrical methods.

President Putin declared, in July of 2014, that, "sanctions have a boomerang effect" threatening that they will cause very serious damage to the West and harm their long-term national strategic interests. ${ }^{5}$ Russia's Foreign Ministry and its officials have made it clear that it intends on "retaliating" to sanctions, as the ministry did in July 17, 2014, proclaiming that, "Blackmail will not be tolerated. We [Russia] reserve the right to retaliate". ${ }^{6}$ On December 19 , 2014, Russia's Foreign Minister Sergei Lavrov escalated his threats as Russia was facing a potential expansion of sanctions by warning that new sanctions against Russia would damage relations, and threatened unspecified consequences for "joint-work that ranges far beyond the Ukraine conflict," which also raised concerns over the Joint Comprehensive Plan of Action (JCPOA) negotiations with Iran at the time. ${ }^{7}$ At the same time, Medvedev labelled sanctions as

${ }^{3}$ Financial Times, "Russia's Medvedev rages against US sanctions," Financial Times, August 9, 2018.

${ }^{4}$ Darya Korsunskaya, Polina Devitt, and Gareth Jones, "Russia's PM: we understand that sanctions pressure will continue," Reuters: World News, February 14, 2019.

5 RadioFreeEurope, “ Russia Blasts New U.S., EU Sanctions As 'Primitive' Measures,” Russia, July 17, 2014.

${ }^{6}$ Michael Birnbaum, "Russia warns of grave consequences from new US sanctions," The Washington Post, July 17, 2014.

7 BBC News, "Ukraine crisis: Lavrov warns over Russia 'regime change' goal," BBC: Europe, November 22, 2014; BBC News, "Russia warns US over sanctions bill," BBC: Europe, December 19, 2014;

Michael Birnbaum, "Russia warns of grave consequences from new US sanctions," The Washington Post, July 17, 2014. 
"evil" and threatened that Russia would increase defence and security expenditure in response. ${ }^{8}$ He proceeded to warn western sender states that, "[Russia and the West] may go back to the 1980s in our relations with the states that are declaring these sanctions," referring to an era of sharp escalation in hostility between the West and Soviet Union arising from the Soviet invasion of Afghanistan, Western rejection of détente policy, and unprecedented nuclear threats. ${ }^{9}$ President Putin, Medvedev, Lavrov, Russian ministries and officials have made Russia's intent to 'retaliate' to sanctions clear - from here, this chapter will observe the four ways that Russia has responded.

\subsection{Russian Entrenchment and Counter Sanctions}

Russia's entrenchment further into its original foreign policy and provoked counter symmetrical measures are evident from Russia's legal codification of its actions to its countersanctions against sender states. First, Russia's entrenchment is seen through the signing of the "Agreement on the Accession of the Republic of Crimea to the Russian Federation" on March 18, 2014, which codified and formalized Russia's annexation of Crimea. ${ }^{10}$ Moreover, two weeks prior, on March 1, Russia's Federation Council agreed to a resolution on the "use of the Armed Forces of Russia in Ukraine," which also formalized Russia's entrenchment of its original

\footnotetext{
8 Ibid.

9 Moscow Times, "Medvedev Says 'Evil' Sanctions Could Lead to Defense Spending Hike," Moscow Times, July 17, 2014.

10 Prezident Rossii, "Podpisan Dogovor o prinyatii Respubliki Krym v Rossiyskyu Federatsiyu," Novosti: Sobytiya, March 18, 2014.
} 
strategy. ${ }^{11}$ Furthermore, Russia established that Crimea will become de facto part of Russia through its yearly investments, and by building the Kerch Strait Bridge, directly connecting Russia to the peninsula. ${ }^{12}$ Sanctions fortified Russia's position and caused a tougher negotiating situation where conceding became unacceptable for both Russia and the EU. Even the EU's EPRS, affirmed that sanctions have stiffened Russia's position as they, "have not persuaded Russia to give back Crimea; on the contrary, Moscow [...] stepped up its military presence in the peninsula to as many as 28,000 troops. Sanctions have not therefore succeeded in persuading Moscow to cut off military support to the rebels or to use its influence over them to end fighting". ${ }^{13}$ The intensity of fighting subsided since 2015, but still continues in eastern Ukraine with Russia still supporting separatist groups financially and militarily. ${ }^{14}$ Russian-backed separatists have held areas in Luhansk and Donetsk — without any major shifts in control over territory — and no progress has been made with regards to any political settlement or legitimate ceasefire. ${ }^{15}$

\footnotetext{
11 Sovet Federatsii, "Sovet Federatsii dal soglasie na ispolzovaniye Vooruzhennykh Sil Rossii na territorie Ukrainy," Vse Novosti, March 1, 2014.

12 Moscow Times, "Crimean Economy Named Fastest Growing in Russia," Moscow Times, June 3, 2019; Andrew Roth, "Putin opens 12-mile bridge between Crimea and Russian mainland," The Guardian, May 15, 2018.

13 Martin Russell, "Sanctions over Ukraine: Impact on Russia,” EPRS | European Parliamentary Research Service, January 2018: 6.

14 United States Mission to the OSCE, "Ongoing Violations of OSCE Principles and Commitments by the Russian Federation and the Situation in Ukraine," PC.DEL/1475/14, December 18, 2014;

European Union, "EU Statement on the Violation of OSCE Principles and Commitments by the Russian Federation and the Situation in Ukraine," OSCE Permanent Council Nr 1004, PC.DEL/675/14, June 12, 2014.
}

15 Martin Russell, "Sanctions over Ukraine: Impact on Russia,” EPRS | European Parliamentary Research Service, January 2018;

It is important to note here that, as mentioned in Chapter 2, the recent prisoner exchange in 2019 was a significant opening to achieving a potential political settlement. However, as discussed in Chapter 2, it has not resulted in any larger settlement or discussions. 
Moreover, Russia has implemented counter-sanctions against sender states of differing types - primarily affecting the EU. First, Russia denied entry to certain Western leaders in March 2014, retaliating against sender states' travel bans. However, the travel ban imposed by Russia did not make it clear as to who was on the "blacklist". ${ }^{16}$ Over one year later, the Russian government subsequently granted permission to share the names of banned individuals with the EU delegation in Moscow. ${ }^{17}$ Russia banned 89 EU politicians and military leaders (including MEPs), along with other individuals from different sender states, on the basis that those individuals were most in favour of sanctions against Russia. ${ }^{18}$ The current list is unclear, as other individuals have been allegedly added. ${ }^{19}$ Secondly, and more prominently, Russia imposed an import ban on several agricultural and food products in August 2014 against sender states Russia's Minister of Agriculture Nikolai Fyodorov confirmed that Russia placed the targeted embargo "in response to sanctions" in late August 2014, and the embargo has been renewed since then every year. ${ }^{20}$ The embargo on meat, fish, fruit, vegetables, and dairy products represented $43 \%$ of EU's agrifood exports to Russia at the time, being the second most significant destination for EU agricultural products. ${ }^{21}$ Some estimates suggest that the embargo

\footnotetext{
16 Russell, “Sanctions over Ukraine: Impact on Russia,” EPRS | European Parliamentary Research Service, January 2018: 5 .

17 Thomas Seymat, "The complete blacklist of EU officials banned from Russia” Euronews, June 2, 2015.

18 Andrew Rettman, “Russia blacklist of EU names 'unjustified'," EUobserver: Foreign Affairs, May 31, 2015.

${ }^{19}$ Baltic Times, "Lithuanian MEP Guoga blacklisted by Russia," Baltic Times, March 24, 2017.

20 Prezident Rossii, “Soveshanie s chlenami Pravitelstva," Novosti: Sobytiya, August 27, 2014.

${ }^{21}$ Russell, "Sanctions over Ukraine: Impact on Russia," EPRS | European Parliamentary Research Service, January 2018: 5 .
} 
cost approximately $€ 125$ million (\$141 million) per month for EU exports. ${ }^{22}$ Also, EU member states were unevenly affected by the ban with most affected being Lithuania $(\$ 927 \mathrm{~m})$, followed by Poland $(\$ 841 \mathrm{~m})$, Germany $(\$ 595 \mathrm{~m})$, Netherlands $(\$ 528 \mathrm{~m})$, and Denmark $(\$ 377 \mathrm{~m}) .23$

\subsection{Reinforced Ties with Western Adversaries and Others}

There have been a number of instances of collaboration between the West and Russia, and more specifically, the EU and Russia. Besides energy trade and cooperation, EU and Russia have shared cooperation through cultural and educational channels, Arctic cooperation, JCPOA, and other channels. Taking into consideration recent Arctic cooperation, although there seems to be some agreement and little clashes of interest, there is a movement of Arctic militarization particularly from Russia due to its extensive Arctic military capacity. ${ }^{24}$ On the other hand, the JCPOA is a good example of Russia's willingness to cooperate with the EU, even in the face of sanctions - since the JCPOA was established a year after sanctions in 2015. However, the JCPOA was a strategic foreign policy maneuver by Russia, due to its nuclear reservations over Iran, and did not change its stance to EU sanctions. At the same time, there were numerous

22 Angela Cheptea and Carl Gaigne, "Russian food embargo and the lost trade," Working Paper SMART - LERECO no. 18-05 (September 2018): 684-718;

Marcin Szczepański, "Economic impact on the EU of sanctions over Ukraine conflict," EPRS | European Parliamentary Research Service, October 2015;

Susanne Kraatz, "The Russian Embargo: Impact on the Economic and Employment Situation in the EU," Policy Department A: Economy and Scientific Policy, PE 536.291, European Parliament, October 2014.

${ }^{23}$ Susanne Kraatz, "The Russian Embargo: Impact on the Economic and Employment Situation in the EU," Policy Department A: Economy and Scientific Policy, PE 536.291, European Parliament, October 2014: 5; Angela Cheptea and Carl Gaigne, "Russian food embargo and the lost trade," Working Paper SMART - LERECO no. 18-05 (September 2018): 684-718.

${ }^{24}$ Demyan Plakhov, "Diplomatic Chess in the Arctic," NATO Association of Canada, June 25, 2018; Jon Rahbek-Clemmensen, "Nye militære spændinger i Nordatlanten og Arktis," Center for Militcere Studier, Københavns Universitet, March 2020. 
events occurring after the implementation of EU sanctions against Russia, which point to Russia's responses that would create inadvertent effects.

After the imposition of sanctions by the EU and other sender states, Russia began reinforcing ties with 'Western adversaries' such as China, Syria, Venezuela, and Iran, as well as Russia's increasing ties with BRICS, and African nations. ${ }^{25}$ Besides Russia's pivot to China through increased military and gas deals as seen in Chapter 3, Russia has been deepening cooperation on various levels. Besides new intergovernmental ties, President Putin and Chinese President Xi Jinping have met at least five times a year — on one of those occasions in 2018, President Xi even awarded President Putin with the Order of Friendship of the People's Republic of China. ${ }^{26}$ From 2017, Russia has become more encouraging of China's Belt and Road Initiative (BRI), developing Eurasian connections, and harmonizing monetary and fiscal policies. ${ }^{27}$ Sanctions and tariffs have brought together the two major players, with influential militaries, economies, and diplomatic resources (including UNSC P5).

With respect to Syria, Venezuela, and Iran, Russia has maintained cooperative relations even before the imposition of EU sanctions in 2014. Russia has maintained positive relations with Syria even during the Soviet Union — exemplified by the signing of the Treaty of Friendship and Cooperation on 8 October, 1980 — and continued its policy by supporting Syria's

25 Marcin Szczepański, "Economic impact on the EU of sanctions over Ukraine conflict," EPRS | European Parliamentary Research Service, October 2015: 6.

26 RIA Novosti, “Mezhgosudarstvennye otnosheniya Rossii i Kitaya,” RIA Novosti, November, 13, 2019.

27 Prezident Rossii, "Mezhdunardnyi forum 'Odin poyas, odin put," Novosti: Sobytiya, April 26, 2019; Xing Guangcheng and Wang Xuemei, "Russia Supports the Chinese Belt and Road Initiative," Valdai | Discussion Club: Expert Opinions, April 25, 2019;

Bloomberg, "Putin Rides to Xi's Rescue on Battered Silk Road as the West Stews," The Moscow Times, April 26, 2019;

Ben Westcott, "Russia switches on gas mega-pipeline to China as Putin touts closer ties," CNN, December 3, 2019. 
President Bashar al-Assad since 2011.28 Russia maintained positive relations with Venezuela's Hugo Chavez through military trade, energy cooperation, and several agreements — including the 2008 nuclear cooperation agreement. ${ }^{29}$ Russia had fluctuating relations with Iran throughout its history, but maintained mostly positive relations with Iran prior to sanctions. ${ }^{30}$ Although Russia has maintained positive relations with these countries before sanctions, it can be observed that Russia did increase their support for these countries, which can be a continuation of foreign policy or due to the worsening of relations with the West. Therefore, although there is a correlation in events, a causal relationship cannot be currently established to directly link certain Russia's actions to EU sanctions.

After political and military support for al-Assad since 2011, Russia commenced direct military involvement in September 2015 with the official objective of defeating terrorism — but really repressing all forms of resistance against al-Assad's government. ${ }^{31}$ This marked the first time that Russia entered an armed conflict outside the borders of the former Soviet Union, since

\footnotetext{
${ }^{28}$ Rami Ginat, "The Soviet Union and the Syrian Ba'th Regime: From Hesitation to Rapprochement," Middle Eastern Studies 36, no. 2 (April 2000): 150-171;

"Soviet-Syrian Treaty of Friendship and Co-operation 8 October 1980," Journal of Survival: Global Politics and Strategy 23, no. 1 (2008): 43-44;

BBC News, "China and Russia veto UN resolution condemning Syria,” BBC: Middle East, October 5, 2011.

${ }^{29}$ UN News, "Venezuela: Competing US, Russia resolutions fail to pass in Security Council," United Nations. February 28, 2019;

Anatoly Kurmanaev, "Why Is Russia Helping Venezuela?” The New York Times, March 8, 2019;

Mark N. Katz, “The Putin-Chavez Partnership," Problems of Post-Communism 53, no. 4 (August 2006): 3-9;

Nuclear Threat Initiative, “Overview,” Venezuela, July 2016.

30 Nikolay Kozhanov, “Russia’s Relations with Iran: Dialogue without Commitments,” Policy Focus no. 120, The Washington Institute for Near East Policy, June 2012.

31 Timothy Snyder, “The Real Reason Russia is 'Helping' Syria," TIME, September 30, 2015;

Holly Ellyatt, "What has Russia got invested in Syria," CNBC: Europe News, September 17, 2015;

Prezident Rossii, "Vstrecha s Prezidentem Sirii Basharom Asadom," Novosti: Sobytiya, October 21, 2015.
} 
the end of the Cold War. ${ }^{32}$ During that time, Russia had used its UNSC seat to veto resolutions against Syria led by sender states, including sanctions against the Syrian government for using chemical weapons - actions confirmed by the UN and OPCW. ${ }^{33}$ Via Syria, Russia has grown its presence in the Middle East. Russia initially provided Russian aircraft, airforce pilots, naval equipment and personnel, combat medics, and even special operations forces, and then grew to establish its own military bases throughout Syria. ${ }^{34}$ Russia expanded its military bases including its Khmeimim Air base, Mediterranean naval access through Latakia and Tartus bases, and its recently established Russian Armed Forces command post near Damascus. ${ }^{35}$ As a result, alAssad continuously praises President Putin for Russia's support in backing his forces in Syria mostly against Western-led rebels and factions, which has undermined western efforts in Syria. ${ }^{36}$

\footnotetext{
32 However, this is also not the first that Russia has used its veto vote based on state sovereignty; Maria Tsvetkova and Anton Zverev, "Ghost soldiers: the Russians secretly dying for the Kremlin in Syria," Reuters: World News, November 3, 2016.

33 BBC News, "Syria war: Russia and China veto sanctions,” BBC News: Middle East, February 28, 2017.

34 Prezident Rossii, “Soveshanie o deystbiyakh Vooruzhiennykh Sil Rossii v Sirii,” Novosti: Sobytiya, November 17, 2015;

Prezident Rossii, "Soveshanie o rukovodstvom Minoborony o deystviyakh Vooruzhiennykh Sil Rossii v Sirii," Novosti: Sobytiya, November 20, 2015.

35 Prezident Rossii, "Vladimir Putin postal Siriyskuyu Arabskuyu Respubliku," Novosti: Sobytiya, January 7, 2020; Holly Ellyatt, "What has Russia got invested in Syria," CNBC: Europe News, September 17, 2015 ;

Jonathan Marcus, "Russia S-400 Syria missile deployment sends robust signal” BBC News: Europe, December 1, 2015.

36 Prezident Rossii, “Telefonniy razgovor s Prezidentom Sirii Basharom Asadom,” Novosti: Sobytiya, March 6, 2020 ;

BBC News, "Syria conflict: FSA rebels reject Russia military help,” BBC News: Europe, October 25, 2015.
} 
Continuous pressure and sanctions have also reinforced ties between Iran and Russia. ${ }^{37}$

EU's sanctions on Iran due to "serious human rights violations" and "non-proliferation of weapons of mass destruction (WMD)" have also encouraged Iran to negotiate and accept assistance from Russia, even after Russia's initial acceptance of inducing sanctions against Iran. ${ }^{38}$ In 2017, President Putin declared that cooperation with Iran had been growing in recent years from Russian investments into Iran and Iran's purchasing of Russian military — while also affirming Iran to be Russia's "kind neighbour and partner". ${ }^{39}$ In 2019, Russia's Minister of Energy Alexander Novak affirmed that Russia will continue to support Iran and claimed that sanctions were "unlawful," further emphasizing how the sanctions regimes have brought the two together. ${ }^{40}$ In June 2019, once again underlining their cooperation, Iran's President Hassan Rouhani went as far as stating that countries falling under sanctions regimes of the west,

37 Reese Erlich, “Trump Is Driving Iran into Russia’s Arms,” Foreign Policy: Dispatch, May 29, 2019; Reid Standish and Amy Mackinnon, "Putin Moves to Heighten Russia’s Role After Suleimani Killing," Foreign Policy: Report, January 8, 2020;

Moscow Times, “Iran 'Won't Be Alone' If U.S. Attacks, Russian Official Says,” The Moscow Times, June 26, 2019 ; It is important to note here that the EU does not sanction Iran anymore, since 2015. However, the US has reimposed sanctions against Iran, and is a sender state for both Iran and Russia. US' sanctions against Iran have encouraged Iran to reinforce ties with Russia, while EU sanctions have encouraged Russia to reinforce ties with Iran.

38 European Union, “Country: Iran,” EU Sanctions Map, April 4, 2020;

Russia supported UNSC Resolution 1929, which passed on June 9, 2010, allowing the fourth round of sanctions against Iran for its failure to halt elements of its nuclear program. Besides many positive aspects of Iranian-Russian relations, Russia has been cautious of Iran's strong regional influence and nuclear capabilities. The nuclear aspect has been a controversial element for Russia before and after 2014 sanctions. In addition, Russia maintained relations with Iran by setting limits on sanctions and including assurances to Iran. Russia's stance also allowed the approval of UN sanctions but the disapproval of additional unilateral sanctions. For more information refer to:

Alexander A. Pikayev, "Why Russia Supported Sanctions Against Iran," Middlebury Institute of International Studies at Monterey, James Martin Center for Nonproliferation Studies, June 23, 2010;

Nuclear Threat Initiative, "Russia’s Lukewarm Support for International Sanctions against Iran: History and Motivations," Nuclear Threat Initiative, April 15, 2020;

Utrikesmagasinet, "The Russia-Iran Relationship in a Sanctions Era," Ultrikespolitiska institutets nattidning, November 2019.

39 Rossiya 24, "Rossiya i Iran vyshli na novyi uroven sotrudnechestva,” Russia: Rossiya 1, Youtube, March 28, 2017.

40 David Reid, "Russian energy minister says tension in the Persian Gulf is not the fault of Iran," CNBC: Oil, July 2, 2019. 
including both Iran and Russia, need to unite against these states. ${ }^{41}$ Relevant to both Syrian and Iranian relations, Nikolay Kozhanov, a Middle East expert and former Russian attaché in Tehran, pointed to this phenomenon in 2015 stating:

"In 2014, tensions between Russia on the one side and the United States and the EU on the other over the Ukraine crisis became another reason for the Kremlin to strengthen cooperation with Iran. The unprecedented [...] scale of confrontation with the West convinced Moscow that intensifying contact with Middle Eastern countries was highly important. Russian authorities believed that good relations with Middle Eastern states would ensure that the Kremlin could avoid international isolation and compensate for the sanctions imposed by the United States, the EU, and their partners. Moscow also developed plans to coordinate efforts with Tehran in the energy market to ensure that the Europeans would not use Iran's resources to decrease their dependence on Russian gas". ${ }^{42}$

Russia also recently increased ties with Venezuela by opposing regime change while sender states, including the EU, favoured regime change led by an opposition leader and selfdeclared interim President Juan Guaidó. ${ }^{43}$ Venezuela and Russia originally had a friendly partnership, however, after sanctions were placed on Russia in 2014 and on Venezuela in 2017 by near identical sender states, the two have reinforced stronger ties — namely against those sender states interests. ${ }^{44}$ Once again, Russia used its UNSC seat to veto key resolutions against Venezuela's government, where Russia’s UNSC representative Vassily Nebenzia directly pointed out that Russia would be against regime change. ${ }^{45}$ In the wake of Venezuela's 2019 presidential

\footnotetext{
41 Segodnya, "Putin provel vstrechu s liderom Irana na sammite SHOS," Russia: NTV, Youtube, June 14, 2019; Robin Wright, "Russia and Iran Deepen Ties to Challenge Trump and the United States," The New Yorker, March 2, 2018.

42 Nikolay Kozhanov, "Understanding the Revitalization of Russian-Iranian Relations," Carnegie Endowment for International Peace, Carnegie Moscow Center, 2015: 11-12.

43 Amy Mackinnon, "Maduro vs. Guaido: A Global Scorecard,” Infographic, February 6, 2019.

${ }^{44}$ European Union, “Country: Venezuela,” EU Sanctions Map, November 11, 2019.

45 DW, "Venezuela: US resolution vetoed by Russia, China at UN Security Council," DW News, March 1, 2019.
} 
crisis, Russia politically and military supported Nicolas Maduro as President — sending Russian troops, 'military specialists', and military equipment. ${ }^{46}$ Besides military and political cooperation, Lavrov also mentioned on February 7, 2020, that "[Russia and Venezuela] agreed to deepen economic, commercial and investment cooperation in several areas despite the illegitimate sanctions," speaking alongside Venezuelan Vice President Delcy Rodriguez. ${ }^{47}$ Lavrov's comments directly underline Russia's actions that aim to continue opposing sender states domestically and by supporting western-opposed regimes such as the one in Venezuela.

Sanctions have also encouraged Russia to pivot to BRICS and African nations politically, militarily, and economically. ${ }^{48}$ In 2018 during a BRICS summit, President Putin asserted that "Russia seeks more cooperation with BRICS nations," emphasizing that Russia "intends on doing everything possible to strengthen trade and investment ties" — an ambitious goal for an already cumulative $\$ 102$ billion trade turnover with BRICS nations. ${ }^{49}$ In 2020, Russia takes over as the group's chairman for one-year, and its priorities include: i) enhancing BRICS foreign policy coordination, ii) enhancing foreign policy coordination and proactivity within the United

\footnotetext{
46 Maria Kiselyova, Carlos Garcia Rawlins, Tom Balmforth, Angus Berwick, Alison Williams, and Steve Orlofsky, "Russian military specialists arrive in Venezuela to service equipment: Interfax," Reuters: World News, September 25, 2019;

Alex Ward, "Why Russia just sent troops to Venezuela," Vox, March 27, 2019;

Karen DeYoung, "Russia sends military planes and advisors into Venezuela, showing off combat strength," National Post, March 26, 2019;

Andrew Roth, "Russia acknowledges presence of troops in Venezuela," The Guardian, March 28, 2019;

BBC News, "Russia to boost Venezuela ties amid US pressure," BBC News: Latin America, February 8, 2020.

${ }^{47}$ Brian Ellsworth and Deisy Buitrago, "Russia foreign minister slams U.S. sanctions during visit to Venezuela," Reuters: World News, February 7, 2020.

48 Prezident Rossii, "Vstrecha s chlenami fraktsii politicheskikh partiy v Gosudarstvennoy Dume," Novosti: Sobytiya, August 14, 2014;

Prezident Rossii, "Soveshanie s chlenami Pravitelstva," Novosti: Sobytiya, August 27, 2014.

${ }^{49}$ Olga Tanas, "Putin Says Russia Seeks More Cooperation With BRICS Nations," Bloomberg: Politics, July 26, 2018;

Prezident Rossii, "Vstrecha litero BRICS," Novosti: Sobytiya, November 14, 2019.
} 
Nations, and iii) renewing BRICS' "Strategy for Partnership in Trade and Investment," and boosting cooperation in specific industries for up to five years (primarily with respect to energy). ${ }^{50}$ It is clear that Russia intends on shifting its trade and investment from markets associated with sender states, and pivoted to alternative markets such as BRICS to expand its political, economic, military, and trade relations. Russia's renewed interest and expanding role within BRICS is working as Russia has brokered several key military and nuclear trade deals, including its S-400 missile system, with India after 2014. ${ }^{51}$ India has also sent technological goods, chemical products, and agricultural goods, all necessary for Russia's substitution of EU's sanctioned products and its own import ban. In 2018, the Indian Embassy in Moscow confirmed that relations are deeply rooted in mutual trust and beneficial cooperation, and looks to expand the "strategic partnership" by further boosting trade turnover to $\$ 30$ billion by 2025 — given that the current level is about $\$ 8$ billion. ${ }^{52}$ Between 2014 and 2019, Russia has been building relations with former President Jacob Zuma, while developing military, nuclear, and trade ties. ${ }^{53}$

Russia also hosted its first-ever Russia-Africa Summit on October 23-24, 2019, with more than 50 African leaders. ${ }^{54}$ Russia had signaled that it intends on returning to Africa

\footnotetext{
50 TASS, "Russia takes over the reins to chair BRICS in 2020," TASS: Russian News Agency, December 31, 2019.

51 Bilal Kuchay, "Russian S-400 missile delivery to India by end of 2021: Official," Al-Jazeera: News Russia, February 5, 2020.

52 Embassy of India in Moscow, "Mezhdunarodnaya Zhizn," Ambassador Pankaj Saran's visit to Chechnya Republic, December 2017.

53 Darya Korsunskaya and Tom Balmforth, "Russia lands nuclear bombers in Africa as Putin hosts continent's leaders," Reuters: World News, October 23, 2019;

Andrew S. Weiss, and Eugene Rumer, "Nuclear Enrichment: Russia's Ill-Fated Influence Campaign in South Africa," The Return of Global Russia, Carnegie Endowment for International Peace, December 2019;

Economist, "South Africa's love-affair with Russia," Economist: Middle East and Africa, March 16, 2017.

${ }^{54}$ Landry Signe, "Vladimir Putin is resetting Russia’s Africa agenda to counter the US and China," Quartz Africa, October 22, 2019.
} 
politically, military, and economically, with Chinese coordination. In 2018, Russia continued to grow its exports to sub-Saharan Africa ( $\$ 3$ billion), and its imports from sub-Saharan Africa (\$1.7 billion). Additionally, Russia has written off debts of African nations, while President Putin called for trade to double over the next four to five years..$^{55}$ During the summit, Russia signed deals in the amount of $\$ 12.5$ billion, including expanding arms deals, oil drilling rights in Equatorial Guinea and Nigeria, and an agreement to build a nuclear power plant in Ethiopia and Egypt. ${ }^{56}$ Besides Asia, Africa is the second biggest defence market for Russia accounting for $\$ 14$ billion or nearly a third of its major arms exports. ${ }^{57}$

As a result, in response to sanctions, Russia has supported Western adversaries and reinforced their positions including China, Syria, Venezuela, and Iran. With China, Russia has supported President Xi's foreign and domestic policy including its BRI project, which competes with western interests. In Syria and Venezuela, Russia supported President al-Assad's and Maduro's governments to stay in power while establishing key military, economic, and political ties. Russia has been able to re-establish ties with Iran's regime after their falling out of the JCPOA and further sanctions. Moreover, Russia has returned to unions to increase partnership that are meant to further its political, economic, and military policy through BRICS and African nations. Russia's memberships in BRICS closely mirror the G7, in an attempt to not only reinforce its original position, but to also respond to global unions.

\footnotetext{
${ }^{55}$ Landry Signe, "Vladimir Putin is resetting Russia's Africa agenda to counter the US and China," Quartz Africa, October 22, 2019.

56 Financial Times, "Russia turns on the charm at first Africa summit," Financial Times, October 24, 2019;

BBC News, "Russia in Africa: What's behind Moscow's push into the continent?" BBC News: World, May 7, 2020.

57 Financial Times, "Russia turns on the charm at first Africa summit," Financial Times, October 24, 2019.

Demyan Plakhov
} 


\subsection{Russia Undermine Sender States and Their Alliances}

In response to sanctions, Russia has also undermined sender states and their alliances through bilateral efforts. This includes Russia's bilateral efforts to expand military trade with Turkey in order to undermine NATO, and Russia's efforts to secure ties with Russian-friendly EU member states and European parties in Hungary, Slovenia, Austria, Germany, France, and Italy. ${ }^{58}$ This was made clear by President Putin in a 2019 interview, when he noted that Russia will take asymmetrical responses, especially given the major changes in contemporary international relations that have less rules than in the Cold War. ${ }^{59}$ In a more recent interview, on the topic of sanctions, Ukraine, and political alliances, President Putin also added that unity is stronger and if you divide a country or alliance, it automatically becomes weaker; which sets the foundation for Russia's foreign policy in dividing nations and alliances on bilateral and even partisan levels. ${ }^{60}$

Russia has tried to politically draw Turkey from the West by supporting Turkey's President Recep Tayipp Erdogan when he faced his attempted coup d'etat. ${ }^{61}$ Russia also supports Turkey's fragmentation with the NATO alliance and continuously tries to undermine Turkey's

\footnotetext{
58 Euronews (in English), "Medvedev slams EU's "hasty decisions" on Russia sanctions,” Euronews, Youtube, October 18, 2018;

Refer to Table 2.1 in Appendix A for the list of EU member states and their perspectives on sanctions against Russia.

59 Financial Times and Vladimir Putin, "Vladimir Putin interviewed by the Financial Times |FT," Financial Times, Youtube, July 5, 2019.

${ }^{60}$ TASS and Vladimir Putin, "20 Questions with Vladimir Putin. Putin on Ukraine,” Russia: TASS, Youtube, February 20, 2020.

${ }^{61}$ Prezident Rossii, "Rossiysko-turetskie peregovory," Novosti: Sobytiya, March 5, 2020;

Andrew Higgins, "Putin and Erdogan Reach Accord to Halt Fighting in Syria," The New York Times, March 5, 2020.

Demyan Plakhov 
membership by successfully exporting Russian military — endangering western security. ${ }^{62}$ Consequently, Russia's efforts to support of Turkey's shift away from the West can be seen most recently in March of 2020, when during a visit to the Kremlin to discuss Syria, President Erdogan publicly emphasized Turkey's “expanding relations with Russia and its cooperation in Syria and elsewhere".63 The large overlap between the EU and NATO member states - one focusing on economics while the other on security — presents a challenge to Russia's strategic interests. ${ }^{64}$ By seeding NATO or EU skepticism, or by encouraging member states to shift away from these alliances, helps Russia to undermine these institutions and their future policy decisions, including their sanctions and defence policy towards Russia. 65

Likewise, Russia has supported Hungary's President Viktor Orban's EU skepticism and pro-Russian stance to put EU's sanctions policy at risk, and to create a more beneficial EU policy

62 Tim Lister, "Turkey bought Russian S-400 missiles designed to down NATO planes. For the US, that's a problem," CNN World, July 13, 2019;Financial Times, "Turkey's embrace of Russia leaves US out in cold." Financial Times. July 18, 2019;

Carlotta Gall and Andrew Higgins, “Turkey Signs Russian Missile Deal, Pivoting From NATO," The New York Times, September 12, 2017;

Sinan Ulgen, "It's Not Too Late to Stop Turkey From Realigning With Russia," Foreign Policy, April 11, 2019.

${ }^{63}$ Russia Insight, "BREAKING! Putin Meets Turkey's Erdogan In Moscow!” Russia: Rossiya 24, Youtube, March 5, 2020.

${ }^{64}$ BBC News, "Russia security paper designates Nato as threat," BBC News: Europe, December 31, 2015; Olga Oliker, "Unpacking Russia's New National Security Strategy," Center for Strategic and International Studies, January 7, 2016;

"Russian National Security Strategy, December 2015 - Full-text Translation," Approved by Russian Federation Presidential Edict 683, December 31, 2015; Holly Ellyatt, "Putin fears the US and NATO are militarizing space and Russia is right to worry, experts say," CNBC: World Politics, December 5, 2019.

${ }^{65}$ Ben Connable, Stephanie Young, Stephanie Pezard, Andrew Radin, Raphael S. Cohen, Katya Migacheva, and James Sladde, "Russia's Hostile Measures: Combating Russian Gray Zone Aggression Against NATO in the Contact, Blunt, and Surge Layers of Competition," RAND Corporation, 2020: ix;

Kimberley Marten, "Reducing Tensions Between Russia and NATO," Council Special Report no. 79, Council on Foreign Relations, Mach 2017: 22;

Warsaw Institute, "NATO-Russia Relations: The Return of the Enemy," Special Report, April 4, 2019: 18; Olga Oliker, Michael J. McNerney, and Lynn E. Davis, "NATO Needs a Comprehensive Strategy for Russia," RAND Corporation. 2015: 11;

Margaret L. Taylor, "Combating disinformation and foreign interference in democracies: Lessons from Europe," Cybersecurity and Election Interference, The Brookings Institution, July 31, 2019. 
towards Russia. ${ }^{66}$ For instance, President Orban visited Moscow on July 15, 2018, where he questioned the EU's policy and sanctions unity by suggesting that "frankly, if it were not for sanctions, which are causing damage, we could be advancing even faster [... as] these measures are harmful, and we are missing many opportunities". ${ }^{67}$ Russia has also attempted to deepen ties with Slovenia, through increased energy trade, dual-investments, and high technology imports, and Slovenia has responded friendly by noting Russia's trade significance for Slovenia. ${ }^{68}$ Outside of the EU, Russia has continued to seek bilateral agreements with Slovenia to deepen these ties in various fields. ${ }^{69}$ This success was transparent during Marjan Šarec's, Slovenian Prime Minister, visit on September 10, 2019, when he noted that Slovenia is discussing to expand "bilateral cooperation in trade, economy, energy, investment and high-tech sectors [...since] the Russian market is very interesting for us". 70

\footnotetext{
66 Financial Times, “Guest post: Viktor Orbán’s own brand of euroscepticism,” Financial Times, May 19, 2014; Zoltan Simon, "How Viktor Orban's Populism May Face Backlash in Budapest," Bloomberg, October 9, 2019; Milan Nic and Andras Racz, "Point of No Return: Viktor Orbán's Divorce from the EPP," DGAP Policy Brief, May $21,2019$.

67 Prezident Rossii, "Vstrecha s Premier-ministrom Vengrii Viktorom Orbanom,” Novosti: Sobytiya, August 28, 2017;

Prezident Rossii, "Vstrecha s Premier-ministrom Vengrii Viktorom Orbanom," Novosti: Sobytiya, July 15, 2018.

68 Embassy of the Republic of Slovenia Moscow, "Russian Federation,” Economic Cooperation, 2020;

Ministry of Foreign Affairs of Republic of Slovenia, "15th Session of the Intergovernmental Slovenian-Russian Commission for Economic Cooperation,” News release, June 14, 2019.

69 TASS, “Russia, Slovenia sign a number of cooperation documents," TASS: Russian News Agency, September 10, 2019;

Embassy of the Republic of Slovenia Moscow, "Russian Federation,” Political Cooperation, 2020.

70 RadioFreeEurope, "Slovenian PM Sarec In Moscow To Discuss Economic Cooperation,” RadioFreeEurope, September 10, 2019.
} 
Russia has responded to EU sanctions by expanding its strategy of dependence, and by increasing its support of pro-Russian and/or Eurosceptic parties. ${ }^{71}$ With Austria, Russia increased its gas exports by $50 \%$ in 2017, and further extended gas dependence by signing a new gas deal in 2018 between Gazprom and OMV that extends Russian gas exports to Austria until at least 2040. ${ }^{72}$ This undermines EU's energy security and diversification policy, which aims to reduce energy dependence primarily from Russia. ${ }^{73}$ Moreover, Russia's influence in Austria has become deeper since sanctions, with more anti-sanctions parties in Austria calling for cooperation rather than confrontation with Russia. After sanctions, in 2016, Russia's main political party United Russia signed a five year cooperation agreement with Austria's far-right Freedom Party (FPÖ), which aims to grow Austrian-Russian trade, economy, and investment. ${ }^{74}$ More significantly from a political perspective, the FPÖ signed the agreement with EU-sanctioned Sergei Zheleznyak, Deputy Speaker of Russia's Lower House. ${ }^{75}$ The FPÖ, specifically the Party leader HeinzChristian Strache, has called for the termination of sanctions against Russia and continues to

\footnotetext{
${ }^{71}$ It is also important to mention that, similar to the previous section on Western adversaries, Russia has supported pro-Russian and Eurosceptic parties in the past. However, it can be observed that Russia's support for such actors has increased after EU sanctions in 2014. At the same time, a direct link or causal relationship is difficult to establish.

72 Moscow Times, "Russia Extends Austria Gas Deal to 2040 After Putin's Visit," The Moscow Times, June 6, 2018; Financial Times, "Gazprom ups gas exports to Austria by 1 billion cubic meters," Financial Times, November 5, 2018.

${ }^{73}$ European Commission, "Diversification of gas supply sources and routes," Energy: Energy Security, March 17, 2020;

European Parliament, "Energy Policy: General Principles," Fact Sheets on the European Union - 2020, February 2020.

${ }^{74}$ Murphy, Francois, Andrew Osborn, and Tom Heneghan. "Austrian far right signs deal with Putin's party, touts Trump ties." Reuters: World News. December 19, 2016;

RUPTLY, "Russia: United Russia and Austria's FPO sign cooperation agreement," Russia: RT, Youtube, December 19, 2016.

75 DW, “Austria’s vice-chancellor urges end to EU Russia sanctions,” DW: News, June 3, 2018.
} 
advocate Euroscepticism, all of which benefits Russia's foreign policy. ${ }^{76}$ Likewise, Germany has also gone against EU interests of energy diversification and continues to collaborate with Russia on Nord Stream II, greatly increasing Russian gas exports. ${ }^{77}$ Germany's eastern states, who historically had extensive relations with the Soviet Union, have collided with western German states over Russian foreign policy — eastern States' premiers had called for the termination of “crippling sanctions". ${ }^{78}$ Furthermore, Russia has pursued to support Germany's Alternative for Germany (AfD) party, which also promotes collaboration with Russia and an end to EU sanctions, and has met party leaders on several occasions. ${ }^{79}$ This was best exemplified by Russia's invitation of AfD leader Frauke Petry in 2017 who met with the leader of the Liberal Democratic Party of Russia Vladimir Zhirinovsky, Speaker of the Duma Vyacheslav Volodin, and the Deputy Speaker of the Duma Pyotr Tolstoy. 80

In France, Russia supported candidates such as Francois Fillon, Jean-Luc Melenchon, and Marine Le Pen, all whom support the termination of EU sanctions against Russia. ${ }^{81}$ Russia supported Le Pen's National Front party in particular, due to the Eurosceptic, anti-sanctions, proRussian stance, with several loans including one in 2014 — right after the annexation of Crimea

\footnotetext{
76 Rupert Wiederwald, “Austria's vice-chancellor urges end to EU Russia sanctions,” DW: News, May 21, 2019.

77 Nord Stream 2, "Nord Stream 2 is a European collaboration,” Nord Stream 2, 2020.

78 Austin Davis, "Russia sanctions debate deepens Germany's east-west divide,” DW: Germany, June 11, 2019.

79 Timothy Jones, "German AfD parliamentarian could be under Russian influence: report," DW News, April 5, 2019;

Anne Applebaum, "Russia is cultivating Germany's far right. Germans don't seem to care," The Washington Post, April 12, 2019.

${ }^{80}$ Hans-Edzard Busemann, Maria Tsvetkova, Joseph Nasr, and Ed Osmond, "Leader of Germany's far-right party meets Putin allies in Moscow," Reuters: World News, February 21, 2017.

${ }^{81}$ Alan Crosby, "Putin May End Up The Winner In French Presidential Vote," RadioFreeEurope, April 22, 2017; Emma-Kate Symons, "The big winner in the French election will be Vladimir Putin," Quartz, April 19, 2017.
} 
and the imposition of EU sanctions - amounting to $€ 11(\$ 12.5)$ million from the First Czech Russian bank and $€ 9$ (\$10.3) million in 2016 prior to the French Presidential elections. ${ }^{82}$ Consequently, Russia's support for anti-sanctions promotion is evident on March 24, 2017 two months before the French Presidential elections — when President Putin outlined how "[Russia] values highly relations with France and [tries] to maintain good relations with incumbent government and the opposition". ${ }^{83}$ However, it is important to note that Le Pen was not the official opposition at the time, and did not hold nowhere near enough seats to be considered as a representative of the opposition to the government — her party held 2 seats in the National Assembly and it was so small that it was unregistered. ${ }^{84}$ President Putin also did not meet with any other candidates. During the same meeting, Le Pen noted to President Putin that her party urges, "the restoration of cultural, economic, and strategic ties between Russia and France". ${ }^{85}$ Russia has also similarly tried to reinforce ties with Mateo Salvini's Lega Nord party and the Five Star Movement in Italy, candidate Geert Wilders who ran for Dutch elections, Europe of Nations and Freedom group in European Parliament, the Belgian Vlaams Belang party, and the Congress of the New Right party in Poland. 86

82 Gabriel Gatehouse, “Marine Le Pen: Who's funding France's far right?” BBC News: Europe, April 3, 2017; Alan Crosby, "Putin May End Up The Winner In French Presidential Vote," RadioFreeEurope, April 22, 2017.

83 Prezident Rossii, "Vstrecha s Marin Le Pen,” Novosti: Sobytiya, March 24, 2017.

${ }^{84}$ Ministere de L’Intérieur de France, “Résultats des élections législatives 2012,” Legislatives, June 17, 2012.

85 Prezident Rossii, "Vstrecha s Marin Le Pen,” Novosti: Sobytiya, March 24, 2017.

86 Peter Teffer, "Wilders says Russia is 'no enemy' ahead of Moscow visit," EUobserver: Foreign Affairs, November 23, 2017;

Darko Janjevic, “EU populists on Russia: Moving out of lockstep,” DW: Europe, June 3, 2018;

Péter Krekó, Marie Macaulay, Csaba Molnár, and Lóránt Győri, "Europe’s New Pro-Putin Coalition: the Parties of 'No'." Political Capital Institute, Institute of Modern Russia. August 3, 2015;

Lisbeth Kirk, "Russia divides Europe's eurosceptic parties," EUobserver: Foreign affairs, April 10, 2019;

Committee on Foreign Relations United States Senate, "Putin's Asymmetric Assault on Democracy in Russia and Europe: Implications for U.S. National Security," A Minority Staff Report, U.S. Government Publishing Office, January 10, 2018. 


\subsection{Russia's Increased State Popularity and Anti-Western Sentiment}

After EU imposed sanctions, there was an increase in public approval of President Putin and state popularity, while increasing anti-Western sentiment. Russian government increased the use of 'Russophobia,' claiming it to be one of the main reasons behind sanctions and justifying the government's policy response. ${ }^{87}$ Based on Medvedev's statements on July 27, 2015 - along with other key Russian decision-makers at various points in time - there is a belief among Russian decision-makers that the cause of EU sanctions are actually due to "anti-Russian hysteria" to achieve political aims. ${ }^{88}$ These remarks directly echo those of President Putin's commentary a year earlier in declaring that, "We are seeing a rise in anti-Russian hysteria. [The EU] is using Russophobia for internal political struggles," and further declaring that Russia "will need to respond because it's impossible to endlessly tolerate this kind of insolence towards our country". ${ }^{89}$ These remarks take on a larger role as they unveil how the Russian government sees sanctions not only as a foreign policy tool but a tool with personal goals, which has an impact on respect and national pride. Medvedev's remarks once again mirror that of President Putin's when he also indicated that the Russian government has many options to respond to this hostility including economic, military, and other means..$^{90}$ On July 25, 2017, the Deputy Foreign Minister

\footnotetext{
${ }^{87}$ Russophobia, or anti-Russian sentiment, is a fear or dislike of Russians, Russia, or other Russia-related subjects. Proponents of this argue that negative representations or over-exaggeration stereotypes are used to instil Russia or Russians as enemies or villains.

${ }^{88}$ RUPTLY, "Slovenia: Sanctions have 'negative impact' on EU and Russia - PM Cerar tells Medvedev," Russia: RT, Youtube, July 27, 2015.

89 AFP, "Putin slams 'rise in anti-Russian hysteria'," France: AFP, Youtube, July 27, 2017.

${ }^{90}$ RUPTLY, “Slovenia: Sanctions have 'negative impact' on EU and Russia - PM Cerar tells Medvedev," Russia: RT, Youtube, July 27, 2015.
} 
Sergei Ryabkov furthered this sentiment by stating that sanctions would plant a "dangerous mine" under the foundation of ties, and claimed it to be due to "Russophobe hysteria". ${ }^{91}$

After the annexation of Crimea, both President Putin's and the Russian government's approval rating rapidly increased. ${ }^{92}$ President Putin's popularity increased from approximately $60 \%$ to over $80 \%$ after the annexation, while the Russian government went from $40 \%$ to $60 \% .{ }^{93}$ On August 6, 2014, Levada Center confirmed that President Putin's approval rating had risen to 87\%. ${ }^{94}$ More surprisingly, President Putin's approval rating kept rising and by June 2015 he recorded his highest approval rating of $89 \%$ - well into the sanctions regime. ${ }^{95}$ With sanctions in place and economic downturn in process, President Putin still recorded some of his highest ratings in $2016(81 \%) .{ }^{96}$ With his rating dropping a few times since then, he maintains his popularity no lower than before sanctions. In 2018, President Putin was re-elected for his fourth term in office at $77 \%$, and Levada Center's polling in 2019 showed that Putin's approval maintained at $68 \%$ or higher. 97 While his approval rating fluctuated, it has stayed relatively higher than prior to the annexation of Crimea and corresponding sanctions. Sanctions may have

\footnotetext{
${ }^{91}$ BBC News, "Russia issues warning as US sanction vote looms," BBC News: US and Canada, July 25, 2017. 92 Statista Research Department, "Vladimir Putin's approval rating in Russia 2000-2020," Society: Politics and Government, May 8, 2020.

93 Economist, "Vladimir Putin's unshakeable popularity,” Graphic Detail: Daily Chart, February 4, 2016.

${ }^{94}$ Levada-Tsentr, “Avgustovskie retying odobreniya,” Press release, August 6, 2014.

${ }^{95}$ Alberto Nardelli, Jennifer Rankin and George Arnett, "Vladimir Putin's approval rating at record levels," The Guardian, July 23, 2015.

96 Julie Ray and Neli Esipova, "Economic Problems, Corruption Fail to Dent Putin's Image," GALLUP: News, March 28, 2017.

97 Andrew Roth, "Vladimir Putin secures record win in Russian presidential election," The Guardian, March 19, 2018; Moscow Times, "Putin's Approval Rating Steadily Increases to 68\%, Survey Says," The Moscow Times, July 5, 2019.
} 
consolidated President Putin's popularity through the Russian government's ability to use sanctions to increase anti-Western sentiment and to blame economic difficulties on sanctions and the West - shaping the image of President Putin and Russian government as defenders of the nation..$^{98}$

The EU's EPRS January 2018 briefing affirmed that although sectoral sanctions have created a "painful" and "aggravated economic downturn," sanctions have not influenced Russian public opinion as planned.99 Citing Levada Center polling, the EPRS noted that despite increasing sanctions, Russian opinion continuously supports President Putin's leadership, the fact that Russia was right in annexing Crimea, and that Russia should continue its current policy despite sanctions throughout 2014-2017.100 The EPRS also found that, "support for Vladimir Putin and the annexation of Crimea has remained constant at over 80\% since March 2014 [up until the end of 2017], while approval ratings for the EU and US have sunk to $38 \%$ and $30 \%$ respectively [from approximately 50\% and 40\%]". ${ }^{101}$ Often referred to as the Crimea effect, Nikolay Petrov from Moscow's Higher School of Economics suggested that a wave of 'euphoria' won over the nation stating that, "in 2014, [Russians] felt anything was possible and everything was allowed," and that the Russian public was excited about the prospects of returning the 'nation's greatness,' which helped avoid discussions about economic difficulties. ${ }^{102}$ Konstantin

\footnotetext{
98 Maria Snegovaya, “Anti-Western Sentiment as the Basis for Russian Unity,” Carnegie Moscow Center, November 4, 2014.

99 Russell, "Sanctions over Ukraine: Impact on Russia," EPRS | European Parliamentary Research Service, January 2018: 1 .

100 Ibid, 6.

101 Russell, "Sanctions over Ukraine: Impact on Russia," EPRS | European Parliamentary Research Service, January
} 2018.

102 Roman Goncharenko, "Vladimir Putin's 'Crimea effect' ebbs away 5 years on,” DW: Europe, March 15, 2019. 
Gaase from the Carnegie Moscow Center also added that the Crimea effect was a unique phenomenon that "was more than just propaganda". 103

Part of the explanation to see the increase and maintenance of President Putin's and the government's approval rating, is to observe the use of state media channels that help propagate pro-government policy and anti-Western sentiment. ${ }^{104}$ Anti-western sentiment in Russia is not new, and existed before sanctions for various reasons, largely establishing itself during the Cold War. ${ }^{105}$ From the Russian perspective, sanctions showed the West's disapproval for Russia's "rightful" actions in Ukraine, and its "historic foundation" with Crimea. Russian state media channels have been reinforcing anti-Western sentiment with anchors such as Dmitry Kisilev, on Rossiya 1, who claims that the West is determined to rewrite history and morals, utilize nuclear weapons against Russia, invade Russia using its NATO forces, threatened that Russia would able to turn the West into "radioactive ashes," how the West faked chemical warfare in Syria, and many other claims. ${ }^{106}$ On June 23, 2016, Kisilev confirmed that his journalism is not neutral and

103 Ibid.

${ }^{104}$ CBC News, "Russian propaganda war against West heats up | Moscow's Version," The National, Youtube, February 4, 2015;

Sharon Werning Rivera, "Understanding the sources of anti-Americanism in the Russian elite," Post-Soviet Affairs 35, no. 5-6 (2019): 376-392;

Ukraine Crisis Media Center, "Image of Great Britain on Russian TV," Ukraine: Ukraine Crisis Media Center, April 10, 2018.

105 Maria Snegovaya, “Anti-Western Sentiment as the Basis for Russian Unity,” Carnegie Moscow Center, November 4, 2014;

Janusz Bugajski, “Moscow’s Anti-Western Social Offensive,” Center For European Policy Analysis, June 13, 2018 ; Ukraine Crisis Media Center, "Image of Great Britain on Russian TV," Ukraine: Ukraine Crisis Media Center, April $10,2018$.

106 Vesti News, “'Kiselev: West Seems Hell-Bent on Rewriting History and Making Everything Fake and Gay!" Russia: Rossiya 1, Youtube, February 23, 2019;

Rossiya 24, "Vesti nedeli s Dmitriem Kiselyovym to 14.04.19," Russia: Rossiya 1, Youtube, April 14, 2019; Vesti News, "Dmitry Kiselyov: The West Has No Shame...They're Using the 'Chemical Weapon' Bogeyman Again," Russia: Rossiya 1, Youtube, January 29, 2018. 
that "the age of neutral journalism has passed". ${ }^{107}$ State media channels, such as Channel One and Rossiya 1, have also created new political talk and news shows promoting anti-Western sentiment including "Vremya Pokazhet", "60 minutes," and "Evening with Vladimir Soloviev". ${ }^{108}$ For instance, on a segment of "Evening with Vladimir Soloviev" broadcasted by Vesti News — sponsored by the All Russia State Television and Radio Broadcasting Company (VGTRK) - on January 25, 2018, Soloviev claimed that the West blames Russia for various fabricated reasons while one of his reoccurring guests, Yakov Kedmi, suggested that, "[the West] has always treated [Russia] aggressively and with disrespect, while Russia responded with kindness $[\ldots]$ well maybe [the West] deserves it" equaling the West to hooligans during the show.

In combination with other analysis, it can be observed that sanctions in combination with pre-existing anti-Western sentiment, President Putin's and the government's opposition to the West, state controlled media, and the reassertion of "great power" status and national pride can exacerbate anti-Western sentiment further and inadvertently increase the popularity of President Putin and the Russian government. ${ }^{109}$ Drezner noted that the history of economic statecraft shows that if a leader is determined to stay in power and willing to sacrifice their population, they will be able to stay in power — citing contemporary examples like Kim Jong-Un, Fidel

\footnotetext{
${ }^{107}$ BBC News, "Russia’s chief spin doctor hits back - BBC News,” BBC News, Youtube, June 23, 2016.

108 Perviy Kanal, "Posle DRSMD. Vremya Pokzhet. 05.03.2019," Russia: Perviy Kanal, Youtube, March 5, 2019; Rossiya 24, "60 minut. Novoe tok-shoy s Olgoy Skabeevoy I Evgeniem Popobym ot 17.07.2018," Russia: Rossiya 1, Youtube, July 17, 2018; Vesti News, "Vladimir Soloviev: West Mired in Bog of Russia-Related Hysteria With No Signs of Improvement," Russia: Rossiya 1, Youtube, January 25, 2018.

${ }^{109}$ Alexey Levinson, "Public opinion and propaganda in Russia," European Council on Foreign Relations, July 28, 2015.
} 
Castro, and Nicholas Maduro. ${ }^{110}$ From another perspective, a European Council on Foreign Relations article by Alexey Levinson shows how the Russian population is willing to suffer the consequences either due to patriotism and/or well-established propaganda, stating that "most Russians see few (if any) practical advantages to the incorporation of Crimea into Russia, but discern, first and foremost, proof that their country has at last acted as a real great power. Russia went ahead and ignored the will and the interests of big, important players in international affairs - the US, NATO and the EU". 111 Therefore, Russian state media channels played a role in increasing the pre-existing sentiments.

\subsection{Conclusions to Inadvertent Effects}

As a result, Russia has responded to sanctions and created inadvertent effects due to their imposition. Due to sanctions, Russia reinforced its commitment behind its original foreign policy, which drew sanctions in the first place. Russia's entrenchment also encouraged it to pursue economic countermeasures such as its import ban, which has negatively impacted the EU. Sanctions have also isolated Russia and encouraged it to reinforce its ties with western adversaries and other strategic partners. This furthered Russian cooperation with China on its initiatives and trade, military-coordinated action in the Middle East to support Syria's al-Assad, support for maintaining Maduro's regime in Venezuela and countering regime change, its return to supporting Iran's regime and its nuclear capabilities - all of which compete with western

\footnotetext{
110 Jorge Luis Perez Valery, and Sean Rameswaram, “Do sanctions work?” Today, Explained, VOX (Podcast), August 19, 2019.

111 Levinson, "Public opinion and propaganda in Russia," European Council on Foreign Relations, July 28, 2015.
}

Demyan Plakhov 
strategic interests. Russia has also maneuvered to enable other alliances and create coordinated economic and security policy with BRICS, and African nations. By deepening ties with and supporting friendly countries and political parties within NATO and the EU, Russia also responded to sanctions by undermining sender states and their alliances. The imposition of sanctions also played a key factor in Russian government controlled media and helped solidify anti-Western sentiment, which in turn favoured the President Putin's and Russian government's approval rating. These responses were made clear by Russia's intent to respond to sender states' sanctions as per public threats and warnings from Medvedev, Lavrov, Russian Foreign Ministry, and even President Putin throughout the sanctions regime. 


\section{Chapter 5: Theoretical and Policy Conclusions}

\subsection{Theoretical Conclusions from the Research}

This research has shown that sanctions implemented by the EU have not been effective in changing Russian foreign policy thus far. The EU's official sanctions' objectives of reversing the annexation of Crimea, preventing the deliberate destabilization of Ukraine, and implementing the Minsk II Agreement by Russia have not been met. Nephew's framework helped explain how the EU has missed some the criteria of an effective sanctions strategy, highlighting its policy gaps. More importantly, this research shows that even with comprehensive and multilateral efforts, the target state may be able to reject, avoid, and adapt to sanctions due to its extensive capabilities. Utilizing Miyagawa's conditions, this case shows how a target state may be able to find resolve to sanctions and reject sender states' objectives. Further, it shows how unique each sanctions case is by understanding the enormous variety of variables from case to case, depending on each sender and target state. Even though both frameworks were crucial in identifying viable theoretical conditions that would explain Russia's unchanged behaviour, they are still inconclusive and require further elaboration of other conditions. 
This thesis was able to uncover additional conditions that enhance a target state's ability to adapt to a sanctions regime, expanding Miyagawa's framework. In the case of Russia, diplomatic influence through the United Nations Security Council and by other means was a legitimate option for limiting the sanctions regime. It adds to Doxey's conclusions by providing an example of how a permanent member state can use its position for its own political purposes. ${ }^{1}$ Russia's nuclear and military capacity also provides interesting evidence for security and game theory literature to further evaluate how nuclear and military power overlaps with sanctions effectiveness. Russia's ability to economically recover all the while maintaining crucial energy trade with Europe will also provide additional evidence to the European energy security literature by showing the deepening energy interdependence of EU and Russia. Finally, this thesis also provides additional evidence to Miyagawa, Portela, Drury, Drezner, and other sanctions literature by showing the link between democracy and sanctions effectiveness, as this case shows that a lack of democratic governance and strong domestic influence of government through the press, religion, and other means has reduced the effectiveness of sanctions.

Furthermore, this case demonstrates how the theoretical effective-ineffective spectrum used to define sanction effectiveness is limited, and how sanctions strategies and target states do not fall into a universal pattern. This paper reveals that the sanctions effectiveness spectrum is larger than expected by showing that a sanctions regime can be in fact inadvertently negative going past the ineffective. If sanctions are defined as effective or ineffective by the amount of policy change that it derives from the target state - assuming sanctions as a significant contributing variable - then it poorly defines ineffective sanctions cases. As seen through this

${ }^{1}$ Doxey, 32-52.

Demyan Plakhov 
case, ineffective sanctions cases can be more accurately divided between target states that do not implement changes and those that implement policy opposite to that of the sanctions aims and/or policy changes that negatively affect sender states. As seen in Figure 5.1, this case provides evidence that besides effective, partially effective, and ineffective sanctions cases, there are also sanctions cases with negative inadvertent effects. The current theoretical spectrum of sanction effectiveness is limited and should be further researched as it can provide a more accurate depiction of unsuccessful sanctions cases, and more nuanced explanations for their failures.

Figure 5.1: The Theoretical Spectrum of Sanctions' Effectiveness Based on Target State's Policy Change as a Response to Sanctions

\section{The Theoretical Spectrum of Sanctions' Effectiveness Based on Target State's Policy Change as a Response to Sanctions}

$\begin{array}{lccc}\text { Positive Change } & \text { Some Change } & \text { No Change } & \text { Negative Change } \\ \begin{array}{l}\text { Effective: } \\ \text { Target State } \\ \text { changes foreign } \\ \text { policy to reflect } \\ \text { sanction aims }\end{array} & \begin{array}{c}\text { Partially Effective: } \\ \text { Target State } \\ \text { completes some } \\ \text { changes according } \\ \text { to sanction aims }\end{array} & \begin{array}{c}\text { Inadvertent: } \\ \text { Target State does } \\ \text { not change } \\ \text { according to } \\ \text { sanction aims }\end{array} & \begin{array}{r}\text { Target State changes } \\ \text { policy to invoke } \\ \text { countermeasures }\end{array} \\ \text { against sender states } \\ \text { Legend: }\end{array}$

\subsection{Policy Conclusions From the Research}

Although EU sanctions' strategy has been well-delivered overall and covers most of Nephew's requirements, it still has key gaps due to its internal divisions, lack of a larger sanctions policy framework and combined military force, and its strong interdependence with 
Russia - particularly in the energy sphere. This research further clarified the EU's actual sanctions in the sphere of misinformation by displaying its limited scope - restrictions on arms trade, dual-use goods, financial measures, individual asset freezes and travel bans, and not on agricultural export or other trade restrictions. It is clear that the EU's sanctions regime is limited to a finite number of individuals and companies with major restrictions, and the practically inexistent trade restrictions on Russia's major vulnerabilities. With respect to the EU's strategic gaps, the six-step approach outlined how the EU faltered in the areas of clearly and continuously identifying sanctions aims to the target state in a unified nature, understanding Russia's ability to find resolve, building proper momentum by significantly increasing sanctions' pressure, and not recalibrating its strategy in a substantial way to prevent Russia from finding resolve.

This research also showed that sanctions had an immediate and severe impact, enhancing economic difficulties faced by Russia at the time. Nonetheless, it also revealed that after 2016 Russia recovered from the initial impact of sanctions. Most literature within the 2014 and 2016 period agreed that sanctions had a detrimental impact, but a more long-term assessment has shown that Russia was able to utilize its trading and diplomatic influence, large and flexible economy, access to secondary states and companies, foreign exchange reserves, largely stateowned economic system and lack of democratic governance, nuclear and military capacity, ability to generate uninterrupted revenue from the energy sector, and its domestic influence of government through various means in order to recover. Further, this research showed how Russia leveraged its abilities to respond to sender states in various ways, creating numerous inadvertent effects. Due to sanctions, Russia consequently entrenched its initial foreign policy, enacted 
counter-measures through an import ban, reinforced its cooperation with western adversaries, deepened ties with various secondary states and formed new alliances, its increased state popularity and anti-Western sentiment, and led activities to undermine sender states and their alliances.

Given that the EU needs to vote every six months on the continuation of sanctions, there are always opportunities for the EU to remove sanctions - with a continuous risk that one member state might prevent a consensus. ${ }^{2}$ However, in removing sanctions, the EU would acknowledge its failure to influence Russia's foreign policy, betray unity with its key allies, signal to Russia that it can avoid punishment from the EU, and create a precedent for other countries that EU sanctions can be lifted without making concessions or meeting any of their objectives. This is a dangerous route for the EU to take, and would be detrimental not only to its sanctions policy, but also to its foreign policy and EU principles. From a plethora of public statements, EU member states who are more skeptical of sanctions against Russia still do not break the EU's consensus, and consistently mention their priority of following the EU policy and staying unified on this issue.

Considering the EU's sanctions strategy towards Russia for the past six years, it is likely that the EU will continue with its current policy, and slowly expand sanctions against Russia. During the past six years, there have been EU member states who have criticized sanctions and advocated for "normalizing relations" with Russia, but the EU has still continuously voted in consensus and extended sanctions. Therefore, even if criticisms arise again, it is still likely that

\footnotetext{
2 With the exception of sanctions against Crimea, which are reviewed every 12 months: Council of the European Union, "Infographic - EU sanctions against Russia over Ukraine," Infographics, May 8, 2020 .
} 
sanctions are going to continue in the same nature. As long as sanctions continue, Russia will likely maintain its agricultural counter-measures and pursue other methods to achieve inadvertent effects. Observing Russia's unchanged statements and behaviour in combination to the newly opened possibility that President Putin might be continuing his term until 2036, the policy from Russia will likely follow a similar path as it did for the past six years. ${ }^{3}$ All things being equal, Russia will likely continue to: i) refrain from conceding or meeting the EU's stated sanctions objectives, ii) pursue means of further adapting to sanctions, and iii) produce inadvertent effects for the EU and other sender states.

Nevertheless, in the face of the agricultural ban, the EU has been able to recover and adapt. Farmers and producers in the EU did suffer from income losses due to a decrease in market prices as a result of sudden oversupply, but not did not suffer substantial job losses. ${ }^{4}$ In addition, the share of agriculture comparing to EU's GDP (1.7\%) and exports $(6.6 \%)$ are relatively low, while some projection models into 2020 and 2030 show that "Russian food import ban will [have] no effect on the EU". ${ }^{5}$ In the long-term it actually might benefit farmers in the EU as Russia's farmers become more competitive, given the dissolution of sanctions and the creation of large free trade between Lisbon and Vladivostok. Consequently, the overwhelming

\footnotetext{
${ }^{3}$ Russia's State Duma (lower house) proposed constitutional amendments that would nullify Putin's presidential terms, allowing him to be re-elected after what was meant to be his final term. The Constitutional Court has approved the constitutional amendments to be made, given that the national referendum on April 22, 2020, will accept these changes;

DW, "Russian court clears way for Putin to stay in power," DW: News, March 16, 2020.

${ }^{4}$ Kraatz, "The Russian Embargo: Impact on the Economic and Employment Situation in the EU," Policy Department A: Economy and Scientific Policy, European Parliament, October 2014: 1.

${ }^{5}$ Kraatz, "The Russian Embargo: Impact on the Economic and Employment Situation in the EU," Policy Department A: Economy and Scientific Policy, European Parliament, October 2014.
}

Martin Banse, Ivan Duric, Linde Gotz, and Verena Laquai, "From the Russian food import ban to free trade from Lisbon to Vladivostok - will farmers benefit?” Journal of International Studies 12, no. 4 (2019): 20. 
literature and analysis suggests that the import ban economically damaged Russia more than EU. Likewise, the EU should consider this as a case exhibiting EU's potential in fundamentally recalibrating its strategy and adapting to new realities.

Even in light of confusing sanctions results and literature, it is still mostly agreed upon that sanctions are still required to be part of a grand strategy and larger policy framework, and should therefore, not be a substitute for policy. The EU, especially with regards to Russia as a target state, cannot turn to sanctions for the primary purpose of expressing discontent to an unfavourable policy. ${ }^{6}$ The tenth and final point of the EU's founding sanctions principles dictates that the EU will work to "further develop the instrument of sanctions in the light of lessons learned and to improve their implementation". ${ }^{7}$ Therefore, based on this research's findings and the EU's principles, it is necessary for the EU to review the sanctions strategy in full and consider its options. Information in Appendix $\mathrm{C}$ will serve as a preliminary analysis of some potential EU policy options going forward, with Tables 2.1 and 2.2 in Appendix D providing a list of companies and individuals that have yet to be sanctioned.

\subsection{Further Research}

After six years of sanctions against Russia, it is imperative for future research and policy analysis to address the future implications of these actions and how the EU - along with other

\footnotetext{
${ }^{6}$ Matthew P. Goodman, Heather A. Conley, Jon B. Alterman, Jeffrey Mankoff, and Moises Rendon, "Are Sanctions Working?" Sanctions and Foreign Policy Speaker Series, Center for Strategic and International Studies, July 31, 2019: 2 .

${ }^{7}$ Council of the European Union, "Basic Principles on the Use of Restrictive Measures (Sanctions)," 10198/1/04 REV 1 PESC 450, June 7, 2004.
} 
sender states - should plan to re-evaluate its sanctions' strategy, given what has occurred thus far. Researchers should also examine the separate of roles that Crimea and Minsk II Agreement sanctions packages play in this dispute — potentially using each as a measure of effectiveness when sanctions have been lifted. With regards to sanctions' effectiveness - when this sanctions case is closed - future research should attempt to identify the degree of sanctions' contribution to policy change, or lack thereof. Additionally, research should look into the implications of the EU shifting to a qualified majority voting (QMV) system for sanctions' questions rather than a unanimous vote - as some preliminary research has shown that this may create more stringent sanctions packages, but with other additional consequences. Other research can investigate the EU-Russia's evolving energy interdependence, how it shaped EU's sanctions, and how it will continue to shape its sanctions. This research also found an array of interesting Russian state media channels, political shows, news casts, and anchors that use various elements to shape public opinion. Future research could observe the use of sanctions, or other relevant elements, by Russia's state media channels for influencing and informing the Russian public. Most importantly, future research should test to see how many other "ineffective" sanctions cases would actually be more fitted for the "negative change" category with inadvertent effects. Also, it would be beneficial to find out how sanctions can be measured based on their effectiveness deduced from their negative impacts — giving to the question whether a sanctions regime that achieved policy change but with great sacrifices was an effective regime altogether, and where would it be placed on the effectiveness spectrum. This would benefit not only scholarly work on sanctions, but be crucial for the practical application of sanctions for key decision-makers to better measure the potential negative aspects of sanctions prior to implementing them. 


\section{Bibliography}

\section{Primary Sources}

Acosta, Jim. "U.S., other powers kick Russia out of G8." CNN politics. March 24, 2014. https:// www.cnn.com/2014/03/24/politics/obama-europe-trip/index.html

AFP. "Putin slams 'rise in anti-Russian hysteria'." France: AFP. Youtube. July 27, 2017. https:// www.youtube.com/watch?v=LezeyxxVLBE

Agence France-Presse in Mayorske. "Ukraine and Russia-backed separatists exchange 200 prisoners." The Guardian. December 29, 2019. https://www.theguardian.com/world/2019/ dec/29/ukraine-begins-prisoner-exchange-with-russia-backed-separatists

Al-Jazeera. "US may impose sanctions on Egypt over Russian fighter jet deal.” AJ Impact: United States. November 18, 2019. https://www.aljazeera.com/ajimpact/impose-sanctionsegypt-russian-fighter-jet-deal-191118172442463.html

ALROSA. "Strategia, Struktura, Istoriya." O nas. 2020. http://www.alrosa.ru/\%D0\%BE\%D0\%BD\%D0\%B0\%D1\%81/

AP Archive. "Putin on Russia natural gas supplies, Syria humanitarian assistance." AP. Youtube. June 10, 2018. https://www.youtube.com/watch?v=PlbvuRUPDzE

Auswartiges Amt. "Außenminister Gabriel und der österreichische Bundeskanzler Kern zu den Russland-Sanktionen durch den US-Senat.” Pressemitteilung. June 15, 2017. https:// www.auswaertiges-amt.de/de/newsroom/170615-kern-russland/290664

Baltic Times. "Lithuanian MEP Guoga blacklisted by Russia.” Baltic Times. March 24, 2017. https://www.baltictimes.com/lithuanian mep guoga blacklisted by russia/

Bank Rossii. "Bank Rossii prinyal resheniye snizit klyuchevuyu stavku na 50 b.p. do $5.5 \%$ godovykh.” Press-relis. April 24, 2020. https://www.cbr.ru/press/keypr/

Bank Rossii. "Mezhdunarodnye rezervy Rossiyskoy Federatsii.” Bazy dannykh. May 1, 2020. https://www.cbr.ru/hd base/mrrf/mrrf m/? UniDbQuery.Posted=True\&UniDbQuery.FromMonth=2\&UniDbQuery.FromYear $=2010 \&$ UniDbQuery.ToMonth=2\&UniDbQuery.ToYear $=2020$

BBC News. "China and Russia veto UN resolution condemning Syria." BBC: Middle East. October 5, 2011. https://www.bbc.com/news/world-middle-east-15177114

BBC News. "Russia in Africa: What's behind Moscow's push into the continent?" BBC News: World. May 7, 2020. https://www.bbc.com/news/world-45035889

BBC News. "Russia issues warning as US sanction vote looms." BBC News: US and Canada. July 25, 2017. https://www.bbc.com/news/world-us-canada-40720153 
BBC News. "Russia security paper designates Nato as threat." BBC News: Europe. December 31, 2015. https://www.bbc.com/news/world-europe-35208636

BBC News. "Russia to boost Venezuela ties amid US pressure." BBC News: Latin America. February 8, 2020. https://www.bbc.com/news/world-latin-america-51423110

BBC News. "Russia warns US over sanctions bill.” BBC: Europe. December 19, 2014. https:// www.bbc.com/news/world-europe-30547775

BBC News. "Russia's chief spin doctor hits back - BBC News." BBC News. Youtube. June 23, 2016. https://www.youtube.com/watch?v=UFEoxjia0u8

BBC News. "Syria conflict: FSA rebels reject Russia military help." BBC News: Europe. October 25, 2015. https://www.bbc.com/news/world-europe-34632483

BBC News. "Syria war: Russia and China veto sanctions." BBC News: Middle East. February 28, 2017. https://www.bbc.com/news/world-middle-east-39116854

BBC News. "Ukraine and pro-Russian separatists exchange prisoners." BBC: Europe. December 29, 2019. https://www.bbc.com/news/world-europe-50938894

BBC News. "Ukraine crisis: Lavrov warns over Russia 'regime change' goal.” BBC: Europe. November 22, 2014. https://www.bbc.com/news/world-europe-30158978

BBC News. "US imposes sanctions on China for buying Russian weapons." BBC News: US \& Canada. September 21, 2018. https://www.bbc.com/news/world-us-canada-45596485

Bennets, Marc. "Ukraine and separatists begin largest prisoner exchange of conflict." The Guardian. December 27, 2017. https://www.theguardian.com/world/2017/dec/27/ukraineand-separatists-begin-largest-prisoner-exchange-of-conflict

Bershidsky, Leonid. "Where Russia’s Foreign Investment Really Comes From.” Bloomberg: Politics and Policy. November 6, 2019. https://www.bloomberg.com/opinion/articles/ 2019-11-06/where-russia-s-foreign-investment-really-comes-from

Bentzen, Naja. “A UN peacekeeping mission in eastern Ukraine?” EPRS / European Parliamentary Research Service. March 2018. https://www.europarl.europa.eu/RegData/ etudes/ATAG/2018/614737/EPRS_ATA(2018)614737_EN.pdf

Bentzen, Naja. "Ukraine and the Minsk II agreement On a frozen path to peace?" EPRS I European Parliamentary Research Service. January 2016. https:// www.europarl.europa.eu/RegData/etudes/BRIE/2016/573951/ EPRS BRI(2016)573951 EN.pdf

Birnbaum, Michael. "Russia warns of grave consequences from new US sanctions." The Washington Post. July 17, 2014. https://go-gale-com.proxy.library.carleton.ca/ps/i.do?

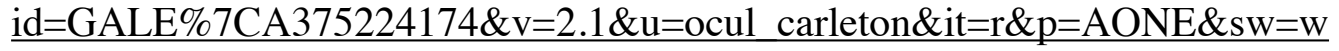


Bloomberg. "Putin Rides to Xi's Rescue on Battered Silk Road as the West Stews." The Moscow Times. April 26, 2019. https://www.themoscowtimes.com/2019/04/26/putin-rides-to-xisrescue-on-battered-silk-road-as-the-west-stews-a65397

Bloomberg QuickTake. "Putin, Zelensky Agree to Prisoner Exchange, Revive Peace Process." France: Bloomberg. Youtube. December 9, 2019. https://www.youtube.com/watch? $\mathrm{v}=\mathrm{THN} 4 \mathrm{zHA} 08 \mathrm{uc}$

Borger, Julian. “G7: Trump's demands for Russia's readmission cause row in Biarritz.” The Guardian. August 25, 2019. https://www.theguardian.com/us-news/2019/aug/25/g7trumps-demands-for-russias-readmission-causes-row-in-biarritz

Burrows, Emma. "Vladimir Putin's inner circle: Who's who, and how are they connected?" CNN. March 28, 2017. https:/www.cnn.com/2017/03/28/europe/vladimir-putins-inner-circle/ index.html

Busemann, Hans-Edzard, Maria Tsvetkova, Joseph Nasr, and Ed Osmond. "Leader of Germany's far-right party meets Putin allies in Moscow." Reuters: World News. February 21, 2017. https://www.reuters.com/article/us-germany-election-afd/leader-of-germanys-far-rightparty-meets-putin-allies-in-moscow-idUSKBN16012C

Bushuev, Mikhail, and Elena Barysheva. "Russia in the Council of Europe: What does it mean for human rights?" DW: Europe. June 26, 2019. https://www.dw.com/en/russia-in-thecouncil-of-europe-what-does-it-mean-for-human-rights/a-49368822

CBC News. "Russian propaganda war against West heats up I Moscow's Version." The National. Youtube. February 4, 2015. https://www.youtube.com/watch?v=fWDgamp6Pvs

CEIC Data. "Russia Crude Oil: Exports.” Countries/Regions: Russia. 2020. https:// www.ceicdata.com/en/indicator/russia/crude-oil-exports

CEIC Data. "Russia Crude Oil: Production.” Countries/Regions: Russia. 2020. https:// www.ceicdata.com/en/indicator/russia/crude-oil-production

CEIC Data. "Russia Foreign Direct Investment." Countries/Regions: Russia. 2020. https:// www.ceicdata.com/en/indicator/russia/foreign-direct-investment

CEIC Data. "Russia Natural Gas: Exports.” Countries/Regions: Russia. 2020. https:// www.ceicdata.com/en/indicator/russia/natural-gas-exports

CEIC Data. "Russia Natural Gas Production: OPEC: Marketed Production." Countries/Regions: Russia. 2020. https://www.ceicdata.com/en/indicator/russia/natural-gas-production-opecmarketed-production

CEIC Data. "Russia Total Exports.” Countries/Regions: Russia. 2020. https://www.ceicdata.com/ en/indicator/russia/total-exports 
Committee on Foreign Relations United States Senate. "Putin's Asymmetric Assault on Democracy in Russia and Europe: Implications for U.S. National Security." A Minority Staff Report. U.S. Government Publishing Office. January 10, 2018. https:// www.foreign.senate.gov/imo/media/doc/FinalRR.pdf

Council of the European Union. "Adoption and review procedure for EU sanctions." Sanctions: how and when the EU adopts restrictive measure. February 14, 2019. https:// www.consilium.europa.eu/en/policies/sanctions/adoption-review-procedure/

Council of the European Union. “Amending Decision 2014/145/CFSP concerning restrictive measures in respect of actions undermining or threatening the territorial integrity, sovereignty and independence of Ukraine." Council Decision (CFSP) 2017/1561. EURLex Publications office. September 15, 2017. https://eur-lex.europa.eu/legal-content/EN/ $\underline{\text { TXT/?uri=celex:32017D1561 }}$

Council of the European Union. "Basic Principles on the Use of Restrictive Measures (Sanctions)." 10198/1/04 REV 1 PESC 450. June 7, 2004. https:// data.consilium.europa.eu/doc/document/ST-10198-2004-REV-1/en/pdf

Council of the European Union. "Concerning restrictive measures in respect of actions undermining or threatening the territorial integrity, sovereignty and independence of Ukraine." Council Decision 2014/145/CFSP. Official Journal of the European Union. March 17, 2014. https://eur-lex.europa.eu/LexUriServ/LexUriServ.do? uri=OJ:L:2014:078:0016:0021:EN:PDF

Council of the European Union. "Concerning restrictive measures in respect of actions undermining or threatening the territorial integrity, sovereignty and independence of Ukraine." Council Decision 2014/145/CFSP. EUR-Lex Publications office. September 14, 2019. https://eur-lex.europa.eu/legal-content/EN/TXT/? qid=1581710395761\&uri=CELEX:02014D0145-20190914\#document1

Council of the European Union. "Equipment covered by Council Common Position 2008/944/ CFSP defining common rules governing the control of exports of military technology and equipment." Notices from European Union Institutions, Bodies, Offices and Agencies. Official Journal of the European Union. March 12, 2019. https://admin.sanctionsmap.eu/ files/2yo3utnom76g9izjg8pdwras7/eu-common-military-list-february-2019.pdf

Council of the European Union. "Illegal annexation of Crimea and Sevastopol: EU extends sanctions by one year." Press releases. Press Office. June 20, 2019. https:// www.consilium.europa.eu/en/press/press-releases/2019/06/20/illegal-annexation-ofcrimea-and-sevastopol-eu-extends-sanctions-by-one-year/

Council of the European Union. "Infographic - EU sanctions against Russia over Ukraine." Infographics. May 8, 2020. https://www.consilium.europa.eu/en/infographics/eusanctions-against-russia-over-ukraine/ 
Council of the European Union. "Overview." Sanctions: how and when the EU adopts restrictive measures. March 6, 2020. https://www.consilium.europa.eu/en/policies/sanctions/

Council of the European Union. "EU extends sanctions over actions against Ukraine's territorial integrity until 15 March 2020.” Press releases. Press Office. September 12, 2019. https:// www.consilium.europa.eu/en/press/press-releases/2019/09/12/eu-extends-sanctions-overactions-against-ukraine-s-territorial-integrity-until-15-march-2020/

Council of the European Union. "EU restrictive measures." Factsheet. Press Office. April 29, 2014. https://www.consilium.europa.eu/uedocs/cms data/docs/pressdata/EN/foraff/ 135804.pdf

Council of the European Union. "EU restrictive measures in response to the crisis in Ukraine." Sanctions: how and when the EU adopts restrictive measures. March 13, 2020. https:// www.consilium.europa.eu/en/policies/sanctions/ukraine-crisis/

Council of the European Union. "Restrictive measures (Sanctions) - Update of the EU Best Practices for the effective implementation of restrictive measures." Foreign Relations Counsellors Working Party 8519/18. May 4, 2018. https://data.consilium.europa.eu/doc/ document/ST-8519-2018-INIT/en/pdf

Council of the European Union. "Russia: EU prolongs economic sanctions by six months." Press releases. Press Office. December 19, 2019. https://www.consilium.europa.eu/en/press/ press-releases/2019/12/19/russia-eu-prolongs-economic-sanctions-by-six-months/

Council of the European Union. "Timeline - EU restrictive measures in response to the crisis in Ukraine." EU restrictive measures in response to the crisis in Ukraine. March 13, 2020. https://www.consilium.europa.eu/en/policies/sanctions/ukraine-crisis/history-ukrainecrisis/

Council of the European Union. "Qualified majority." Voting System. March 23, 2020. https:// www.consilium.europa.eu/en/council-eu/voting-system/qualified-majority/

Coynash, Halya. "Majority of Ukrainians against 'special status' for occupied Donbas." Kharkiv Human Rights Protection Group: Politics and Human Rights. October 16, 2019. http:// khpg.org/en/index.php?id=1570897105

Crosby, Alan. "Putin May End Up The Winner In French Presidential Vote." RadioFreeEurope. April 22, 2017. https://www.rferl.org/a/france-election-macron-le-pen-fillon-melenchonputin-russia/28445679.html

DAMLER. "Opening of Mercedes-Benz Cars passenger car plant in Russia." Company: Locations. 2020. https://www.daimler.com/company/locations/opening-car-plantmoscow.html 
Davis, Austin. "Russia sanctions debate deepens Germany's east-west divide." DW: Germany. June 11, 2019. https://www.dw.com/en/russia-sanctions-debate-deepens-germanys-eastwest-divide/a-49140047

Department for International Trade (DIT) and the Department for Business, Energy and Industrial Strategy (BEIS) of the United Kingdom. "EU-28 exports of goods in 2018." EU-28 trade in goods with Chile since 2000. Based on UN Comtrade data (2020). https:// dit-trade-vis.azurewebsites.net/? reporter $=97 \&$ partner $=152 \&$ type $=C \&$ year $=2018 \&$ flow $=2 \&$ commodity

Department for International Trade (DIT) and the Department for Business, Energy and Industrial Strategy (BEIS) of the United Kingdom. "EU-28 - Top-10 exports of goods to World in 2018." EU-28 exports of goods in 2018. Based on UN Comtrade data (2020). https://dit-trade-vis.azurewebsites.net/? reporter $=97 \&$ partner $=0 \&$ type $=C \&$ year $=2018 \&$ flow $=2 \&$ commodity

Department for International Trade (DIT) and the Department for Business, Energy and Industrial Strategy (BEIS) of the United Kingdom. "EU-28 - Top-10 export markets for goods in 2018." EU-28 exports of goods in 2018. Based on UN Comtrade data (2020). https://dit-trade-vis.azurewebsites.net/? reporter $=97 \&$ partner $=0 \&$ type $=$ C\&year $=2018 \&$ flow $=2$

Department for International Trade (DIT) and the Department for Business, Energy and Industrial Strategy (BEIS) of the United Kingdom. "EU-28 trade in goods with Mexico since 2000." EU-28 exports of goods in 2018. Based on UN Comtrade data (2020). https:// dit-trade-vis.azurewebsites.net/? reporter $=97 \&$ partner $=484 \&$ type $=C \&$ year $=2018 \&$ flow $=2 \&$ commodity

Department for International Trade (DIT) and the Department for Business, Energy and Industrial Strategy (BEIS) of the United Kingdom. "Russian Federation - Top-10 import markets for goods in 2018." Russian Federation exports of goods in 2018. Based on UN Comtrade data (2020). https://dit-trade-vis.azurewebsites.net/? reporter $=643 \&$ partner $=0 \&$ type $=\mathrm{C} \&$ year $=2018 \&$ flow $=2 \&$ commodity

Department for International Trade (DIT) and the Department for Business, Energy and Industrial Strategy (BEIS) of the United Kingdom. "Russian Federation - Top-10 import markets for Nuclear reactors, boilers, machinery, etc in 2018." Russian Federation exports of Nuclear reactors, boilers, machinery, etc in 2018. Based on UN Comtrade data (2020). https://dit-trade-vis.azurewebsites.net/? reporter $=643 \&$ partner $=0 \&$ type $=C \&$ commodity $=84 \&$ year $=2018 \&$ flow $=2$

Department for International Trade (DIT) and the Department for Business, Energy and Industrial Strategy (BEIS) of the United Kingdom. "Russian Federation - Top-10 import markets for Vehicles other than railway, tramway in 2018." Russian Federation exports of Vehicles other than railway, tramway in 2018. Based on UN Comtrade data (2020). 
https://dit-trade-vis.azurewebsites.net/?

reporter $=643 \&$ partner $=0 \&$ type $=C \&$ commodity $=87 \&$ year $=2018 \&$ flow $=2$

Department for International Trade (DIT) and the Department for Business, Energy and Industrial Strategy (BEIS) of the United Kingdom. "Russian Federation - Top-10 export markets for Nuclear reactors, boilers, machinery, etc in 2018." Russian Federation exports of Nuclear reactors, boilers, machinery, etc in 2018. Based on UN Comtrade data (2020). https://dit-trade-vis.azurewebsites.net/? reporter $=643 \&$ partner $=0 \&$ type $=C \&$ commodity $=27 \&$ year $=2018 \&$ flow $=2$

Department for International Trade (DIT) and the Department for Business, Energy and Industrial Strategy (BEIS) of the United Kingdom. "Russian Federation - Top-10 imports of goods from Japan in 2018." Russian Federation exports of goods in 2018. Based on UN Comtrade data (2020). https://dit-trade-vis.azurewebsites.net/? reporter $=643 \&$ partner $=392 \&$ type $=\mathrm{C} \&$ year $=2018 \&$ flow $=2 \&$ commodity

Department for International Trade (DIT) and the Department for Business, Energy and Industrial Strategy (BEIS) of the United Kingdom. "Russian Federation - Top-10 imports of goods to USA in 2018." Russian Federation exports of goods in 2018. Based on UN Comtrade data (2020). https://dit-trade-vis.azurewebsites.net/? reporter $=643 \&$ partner $=842 \&$ type $=\mathrm{C} \&$ year $=2018 \&$ flow $=2 \&$ commodity

Department for International Trade (DIT) and the Department for Business, Energy and Industrial Strategy (BEIS) of the United Kingdom. "Russian Federation - Top-10 export markets for goods in 2018." Russian Federation exports of goods in 2018. Based on UN Comtrade data (2020). https://dit-trade-vis.azurewebsites.net/? reporter $=643 \&$ partner $=0 \&$ type $=$ C\&year $=2018 \&$ flow $=2 \&$ commodity

Department for International Trade (DIT) and the Department for Business, Energy and Industrial Strategy (BEIS) of the United Kingdom. "Russian Federation - Top-10 export markets for Mineral fuels, oils, distillation products, etc in 2018." Russian Federation exports of Mineral fuels, oils, distillation products, etc in 2018. Based on UN Comtrade data (2020). https://dit-trade-vis.azurewebsites.net/? reporter $=643 \&$ partner $=0 \&$ type $=C \&$ commodity $=27 \&$ year $=2018 \&$ flow $=2$

Department for International Trade (DIT) and the Department for Business, Energy and Industrial Strategy (BEIS) of the United Kingdom. "Russian Federation - Top-10 exports of goods to Israel in 2018." Russian Federation exports of goods in 2018. Based on UN Comtrade data (2020). https://dit-trade-vis.azurewebsites.net/? reporter $=643 \&$ partner $=376 \&$ type $=\mathrm{C} \&$ year $=2018 \&$ flow $=2 \&$ commodity

Department for International Trade (DIT) and the Department for Business, Energy and Industrial Strategy (BEIS) of the United Kingdom. "Russian Federation - Top-10 exports of goods to Japan in 2018." Russian Federation exports of goods in 2018. Based on UN Comtrade data (2020). https://dit-trade-vis.azurewebsites.net/? reporter $=643 \&$ partner $=392 \&$ type $=\mathrm{C} \&$ year $=2018 \&$ flow $=2 \&$ commodity 
Department for International Trade (DIT) and the Department for Business, Energy and Industrial Strategy (BEIS) of the United Kingdom. "Russian Federation - Top-10 exports of goods to USA in 2018." Russian Federation exports of goods in 2018. Based on UN Comtrade data (2020). https://dit-trade-vis.azurewebsites.net/? reporter $=643 \&$ partner $=842 \&$ type $=C \& y e a r=2018 \&$ flow $=2 \&$ commodity

Department for International Trade (DIT) and the Department for Business, Energy and Industrial Strategy (BEIS) of the United Kingdom. "Russian Federation - Top-10 exports of goods to World in 2018." Russian Federation exports of goods in 2018. Based on UN Comtrade data (2020). https://dit-trade-vis.azurewebsites.net/? reporter $=643 \&$ partner $=0 \&$ type $=$ C \&year $=2018 \&$ flow $=2$

Department for International Trade (DIT) and the Department for Business, Energy and Industrial Strategy (BEIS) of the United Kingdom. "Russian Federation trade in goods with Chile since 1996." Russian Federation exports of goods in 2018. Based on UN Comtrade data (2020). https://dit-trade-vis.azurewebsites.net/? reporter $=643 \&$ partner $=152 \&$ type $=C \& y e a r=2018 \&$ flow $=2 \&$ commodity

Department for International Trade (DIT) and the Department for Business, Energy and Industrial Strategy (BEIS) of the United Kingdom. "Russian Federation trade in goods with China since 1996." Russian Federation exports of goods in 2018. Based on UN Comtrade data (2020). https://dit-trade-vis.azurewebsites.net/? reporter $=643 \&$ partner $=156 \&$ type $=C \& y e a r=2018 \&$ flow $=2 \&$ commodity

Department for International Trade (DIT) and the Department for Business, Energy and Industrial Strategy (BEIS) of the United Kingdom. "Russian Federation trade in goods with Israel since 1996." Russian Federation exports of goods in 2018. Based on UN Comtrade data (2020). https://dit-trade-vis.azurewebsites.net/? reporter $=643 \&$ partner $=376 \&$ type $=C \& y e a r=2018 \&$ flow $=2 \&$ commodity

Department for International Trade (DIT) and the Department for Business, Energy and Industrial Strategy (BEIS) of the United Kingdom. "Russian Federation trade in goods with Mexico since 1996." Russian Federation exports of goods in 2018. Based on UN Comtrade data (2020). https://dit-trade-vis.azurewebsites.net/? reporter $=643 \&$ partner $=484 \&$ type $=C \&$ year $=2018 \&$ flow $=2 \&$ commodity

Department for International Trade (DIT) and the Department for Business, Energy and Industrial Strategy (BEIS) of the United Kingdom. "Russian Federation trade in goods with Republic of Korea since 1996." Russian Federation exports of goods in 2018. Based on UN Comtrade data (2020). https://dit-trade-vis.azurewebsites.net/? reporter $=643 \&$ partner $=410 \&$ type $=C \&$ year $=2018 \&$ flow $=2 \&$ commodity

Department for International Trade (DIT) and the Department for Business, Energy and Industrial Strategy (BEIS) of the United Kingdom. "Russian Federation trade in goods with Turkey since 1996." Russian Federation exports of goods in 2018. Based on UN 
Comtrade data (2020). https://dit-trade-vis.azurewebsites.net/? reporter $=643 \&$ partner $=792 \&$ type $=C \& y e a r=2018 \&$ flow $=2 \&$ commodity

Department for International Trade (DIT) and the Department for Business, Energy and Industrial Strategy (BEIS) of the United Kingdom. "Russian Federation trade in goods with World since 1996." Russian Federation exports of goods in 2018. Based on UN Comtrade data (2020). https://dit-trade-vis.azurewebsites.net/? reporter $=643 \&$ partner $=0 \&$ type $=\mathrm{C} \&$ year $=2018 \&$ flow $=2$

Department for International Trade (DIT) and the Department for Business, Energy and Industrial Strategy (BEIS) of the United Kingdom. "Russian Federation trade in services with World since 2000." Russian Federation exports of services in 2018. Based on UN Comtrade data (2020). https://dit-trade-vis.azurewebsites.net/? reporter $=643 \&$ partner $=0 \&$ type $=S \& y e a r=2018 \&$ flow $=2 \&$ commodity

Department of Foreign Affairs and Trade. "Russia." Sanctions Regimes. Australian Government. 2020. https://www.dfat.gov.au/international-relations/security/sanctions/sanctionsregimes/Pages/russia

Detsch, Jack. "Report: Iran likely to buy Russian and Chinese arms." Al-Monitor. November 19, 2019. https://www.al-monitor.com/pulse/originals/2019/11/iran-buy-russia-china-arms-unembargo.html

Dewan, Angela. "These are all the countries that are expelling Russian diplomats." $C N N$. March 28, 2018. https://www.cnn.com/2018/03/26/europe/full-list-of-russian-diplomats-expelledover-s-intl/index.html

DeYoung, Karen. "Russia sends military planes and advisors into Venezuela, showing off combat strength." National Post. March 26, 2019. https://nationalpost.com/news/world/russiasends-military-planes-and-advisors-into-venezuela-showing-off-combat-strength

DW. "Austria's vice-chancellor urges end to EU Russia sanctions.” DW: News. June 3, 2018. https://www.dw.com/en/austrias-vice-chancellor-urges-end-to-eu-russia-sanctions/ $\underline{\mathrm{a}-44058919}$

DW. "Russian court clears way for Putin to stay in power." DW: News. March 16, 2020. https:// www.dw.com/en/russian-court-clears-way-for-putin-to-stay-in-power/a-52797553

DW. "Venezuela: US resolution vetoed by Russia, China at UN Security Council." DW News. March 1, 2019. https://www.dw.com/en/venezuela-us-resolution-vetoed-by-russia-chinaat-un-security-council/a-47734238

Economist. "Global Democracy Index 2019.” Infographic. 2019. https:// infographics.economist.com/2020/democracy-index-2019/map.html 
Economist. "Vladimir Putin's unshakeable popularity." Graphic Detail: Daily Chart. February 4, 2016. https://www.economist.com/graphic-detail/2016/02/04/vladimir-putinsunshakeable-popularity

Economist Intelligence Unit. “Daily Chart.” EUI Democracy Index 2020. January 22, 2020. https://www.economist.com/graphic-detail/2020/01/22/global-democracy-has-another$\underline{\text { bad-year }}$

Elliott, Larry. "Russian central bank raises interest rate to $17 \%$ to prevent rouble's collapse." The Guardian: Europe. December 15, 2014. https://www.theguardian.com/world/2014/dec/15/ russia-interest-rate-rise-17pc-rouble-collapse-oil-price

Ellsworth, Brian, and Deisy Buitrago. "Russia foreign minister slams U.S. sanctions during visit to Venezuela." Reuters: World News. February 7, 2020. https://www.reuters.com/article/ us-venezuela-russia/russia-foreign-minister-slams-u-s-sanctions-during-visit-to-venezuelaidUSKBN2011KU

Ellyatt, Holly. "Are Russia and China the best of friends now? It's complicated, analysts say." CNBC: World Politics. September 27, 2019. https://www.cnbc.com/2019/09/27/russiaand-chinas-relationship--how-deep-does-it-go.html

Ellyatt, Holly. "Putin fears the US and NATO are militarizing space and Russia is right to worry, experts say." CNBC: World Politics. December 5, 2019. https://www.cnbc.com/ 2019/12/05/nato-in-space-putin-is-worried-about-the-militarization-of-space.html

Ellyatt, Holly. "Russia conducts massive military drills with China, sending a message to the West." CNBC: Defense. September 16, 2019. https://www.cnbc.com/2019/09/17/russiaconducts-tsentr-2019-military-exercises-with-china-and-india.html

Ellyatt, Holly. "What has Russia got invested in Syria." CNBC: Europe News. September 17, 2015. https://www.cnbc.com/2015/09/17/what-has-russia-got-invested-in-syria.html

Embassy of India in Moscow. "Mezhdunarodnaya Zhizn.” Ambassador Pankaj Saran's visit to Chechnya Republic. December 2017. https://indianembassy-moscow.gov.in/70-years-ofindia-russia-relations-a-historic-milestone.php

Embassy of the Republic of Slovenia Moscow. "Russian Federation." Political Cooperation. 2020. http://www.moscow.embassy.si/index.php?id=4381\&L=1

Embassy of the Republic of Slovenia Moscow. "Russian Federation." Economic Cooperation. 2020. http://www.moscow.embassy.si/index.php?id=3065\&L=1

Euronews (na russkom). "Minfin Rossii podschital usherb ot sanktsiy i obvala tsen na neft economy." Russia: Euronews. Youtube. November 24, 2014. https://www.youtube.com/ watch?v=wU94Q8MLDLc 
Euronews (in English). "Live I French President Emmanuel Macron hosts Russia's Vladimir Putin for a visit." France: Euronews. Youtube. August 19, 2019. https:// www.youtube.com/watch?v=Kx4P50yLSag

Euronews (in English). "Medvedev slams EU's "hasty decisions" on Russia sanctions." Euronews. Youtube. October 18, 2018. https://www.youtube.com/watch?v=ihhSs3_aFtE

European Commission. “2.1 Where does our energy come from?” Eurostat. April 2020. https:// ec.europa.eu/eurostat/cache/infographs/energy/bloc-2a.html

European Commission. "Association of South East Asian Nations (ASEAN)." Countries and regions. May 5, 2020. https://ec.europa.eu/trade/policy/countries-and-regions/regions/ asean/

European Commission. "Diversification of gas supply sources and routes." Energy: Energy Security. March 17, 2020. https://ec.europa.eu/energy/topics/energy-security/ diversification-of-gas-supply-sources-and-routes_en?redir=1

European Commission. "JOINT STAFF WORKING DOCUMENT: Association Implementation Report on Ukraine." High Representative of the Union for Foreign Affairs and Security Policy. SWD(2019) 433 final. December 13, 2019. https://data.consilium.europa.eu/doc/ document/ST-15105-2019-INIT/en/pdf

European Commission. "Special Eurobarometer 451: Future of Europe.” Directorate-General for Communication. December 2016. https://ec.europa.eu/commfrontoffice/publicopinion/ index.cfm/ResultDoc/download/DocumentKy/77406

European Commission. “Trade Picture.” Countries and regions: Russia. May 20, 2020. https:// ec.europa.eu/trade/policy/countries-and-regions/countries/russia/

European Council. "External relations." Meetings: European Council, 19-20 March 2015. May 2, 2018. https://www.consilium.europa.eu/en/meetings/european-council/2015/03/19-20/

European Council. "Remarks by President Donald Tusk after the EU-Ukraine summit in Kyiv." Press releases: Statements and remarks. July 8, 2019. https://www.consilium.europa.eu/ en/press/press-releases/2019/07/08/remarks-by-president-donald-tusk-after-the-euukraine-summit-in-kiev/

European Council on Foreign Relations. "What next for EU sanctions on Russia?" ECFR Views from the Capitals. 2015. https://www.ecfr.eu/debate/ what_next_for_eu_sanctions_on_russia501

European Parliament. "Energy Policy: General Principles." Fact Sheets on the European Union 2020. February 2020. https://www.europarl.europa.eu/ftu/pdf/en/FTU 2.4.7.pdf

European Union. “Country: Iran.” EU Sanctions Map. April 4, 2020. https:// www.sanctionsmap.eu/\#/main/details/17,18/? 
checked $=17,18 \&$ search $=\% 7 \mathrm{~B} \% 22$ value $\% 22: \% 22 \% 22, \% 22$ searchType $\% 22: \% 7 \mathrm{~B} \% 7 \mathrm{D} \% 7$ $\underline{\mathrm{D}}$

European Union. "Country: Russia." EU Sanctions Map. March 4, 2020. https:// www.sanctionsmap.eu/\#/main/details/26,36,35/? checked $=26,36,35 \&$ search $=\% 7 \mathrm{~B} \% 22$ value $\% 22: \% 22 \% 22, \% 22$ searchType $\% 22: \% 7 \mathrm{~B} \% 7 \mathrm{D}$ $\underline{\% 7 \mathrm{D}}$

European Union. "Country: Venezuela." EU Sanctions Map. November 11, 2019. https:// www.sanctionsmap.eu/\#/main/details/44/? checked $=26,36,35 \&$ search $=\% 7 \mathrm{~B} \% 22$ value $\% 22: \% 22 \% 22, \% 22$ searchType $\% 22: \% 7 \mathrm{~B} \% 7 \mathrm{D}$ $\underline{\% 7 \mathrm{D}}$

European Union. EU Sanctions Map. May 13, 2020. https://www.sanctionsmap.eu/\#/main? checked $=$

European Union. "EU Statement on the Violation of OSCE Principles and Commitments by the Russian Federation and the Situation in Ukraine." OSCE Permanent Council Nr 1004. PC.DEL/675/14. June 12, 2014. https://www.osce.org/pc/119941?download=true

Eurostat. "Energy, transport and environment statistics." European Union. 2019. https:// ec.europa.eu/eurostat/documents/3217494/10165279/KS-DK-19-001-EN-N.pdf/ 76651a29-b817-eed4-f9f2-92bf692e1ed9

Eurostat. "EU imports of energy products - recent developments." Statistics Explained. November 2019. https://ec.europa.eu/eurostat/statistics-explained/pdfscache/46126.pdf

Financial Times. "Berlin hits back at US move to tighten sanctions on Russia." Financial Times. June 15, 2017. https://www.ft.com/content/27e28a44-51b0-11e7-a1f2-db19572361bb

Financial Times. "Gazprom ups gas exports to Austria by 1 billion cubic meters." Financial Times. November 5, 2018. https://www.ft.com/content/90ecea12-e0dd-11e8a6e5-792428919cee

Financial Times. "Guest post: Viktor Orbán's own brand of euroscepticism.” Financial Times. May 19, 2014. https://www.ft.com/content/a16d9879-9b1f-388d-895e-da3b5da90277

Financial Times. "Russia turns on the charm at first Africa summit." Financial Times. October 24, 2019. https://www.ft.com/content/b042bd8e-f648-11e9-9ef3-eca8fc8f2d65

Financial Times. "Russia's Medvedev rages against US sanctions." Financial Times. August 9, 2018. https://www.ft.com/content/6c1b18f8-9c68-11e8-9702-5946bae86e6d

Financial Times. "Turkey's embrace of Russia leaves US out in cold." Financial Times. July 18, 2019. https://www.ft.com/content/a8ede83c-a96e-11e9-984c-fac8325aaa04 
Financial Times, and Vladimir Putin. "Vladimir Putin interviewed by the Financial Times I FT." Financial Times. Youtube. July 5, 2019. https://www.youtube.com/watch?v=FbY0VpyjtuI

France-24. "Russia readmission divides leaders at Macron's G7.” France: AFP. August 26, 2019. https://www.france24.com/en/20190826-russia-readmission-divides-leaders-at-macron-s$\mathrm{g} 7$

Freedom House. "Russia." Freedom in the World 2020. 2020. https://freedomhouse.org/country/ russia/freedom-world/2020

Forrer, John J. “Do Secondary Sanctions Work?” World Economic Forum. August 31, 2018. https://www.weforum.org/agenda/2018/08/are-secondary-sanctions-effective/

Gall, Carlotta, and Andrew Higgins. "Turkey Signs Russian Missile Deal, Pivoting From NATO." The New York Times. September 12, 2017. https://www.nytimes.com/ 2017/09/12/world/europe/turkey-russia-missile-deal.html

Gatehouse, Gabriel. “Marine Le Pen: Who's funding France's far right?” BBC News: Europe. April 3, 2017. https://www.bbc.com/news/world-europe-39478066

Gazprom. “Aleksey Borisovich Miller.” O 'Gazprome’: Upravlenie. 2020. https:// www.gazprom.ru/about/management/board/miller/

Gazprom. “O ‘Gazprome’.” Gazprom. 2020. https://www.gazprom.ru/about/

Gazprom-Neft. “'Gazprom neft' vkratse.” O kampanii. 2020. https://www.gazprom-neft.ru/ company/about/at-a-glance/

Gessen, Masha. "The Release of Oleg Sentsov and the Plight of Those Left Behind." The New Yorker. September 10, 2019. https://www.newyorker.com/news/our-columnists/therelease-of-oleg-sentsov-and-the-plight-of-those-left-behind

Goncharenko, Roman. "Ukraine conflict: Can the Minsk-2 peace deal with Russia be salvaged?" DW: Europe. February 12, 2020. https://www.dw.com/en/ukraine-conflict-can-theminsk-2-peace-deal-with-russia-be-salvaged/a-52346015

Goncharenko, Roman. "Vladimir Putin's 'Crimea effect' ebbs away 5 years on." DW: Europe. March 15, 2019. https://www.dw.com/en/vladimir-putins-crimea-effect-ebbs-away-5years-on/a-47941002

Goodman, Matthew P., Heather A. Conley, Jon B. Alterman, Jeffrey Mankoff, and Moises Rendon. “Are Sanctions Working?" Sanctions and Foreign Policy Speaker Series. Center for Strategic and International Studies. July 31, 2019. https://csisprod.s3.amazonaws.com/s3fs-public/event/ 190731 sanctions working foreign policy.pdf?nC4g.n3m4WfbVsBs8k8harhpepxoBZb5 
Government of Canada. "Canadian Sanctions Related to Russia." Canadian Sanctions. January 14, 2020. https://www.international.gc.ca/world-monde/international relationsrelations_internationales/sanctions/russia-russie.aspx?lang=eng

Government of the United Kingdom. "Minister for Europe statement: attempted hacking of the OPCW by Russian military intelligence." Cyber security: Speech. October 4, 2018. https://www.gov.uk/government/speeches/minister-for-europe-statement-attemptedhacking-of-the-opcw-by-russian-military-intelligence

Government of the United Kingdom. "Collection: UK sanctions on Russia." Embargoes and Sanctions. October 4, 2018. https://www.gov.uk/government/collections/uk-sanctions-on$\underline{\text { russia }}$

Higgins, Andrew. "Putin and Erdogan Reach Accord to Halt Fighting in Syria." The New York Times. March 5, 2020. https://www.nytimes.com/2020/03/05/world/europe/putin-erdogansyria.html

International Criminal Court. Rome Statute of the International Criminal Court. A/CONF.183/9. July 17, 1998. https://www.icc-cpi.int/resource-library/documents/rs-eng.pdf

International Monetary Fund. "General government gross debt: Percent of GDP.” IMF DataMapper. April 2020. https://www.imf.org/external/datamapper/ GGXWDG_NGDP@WEO/RUS

International Monetary Fund. "General government net lending/borrowing: Percent of GDP." IMF DataMapper. April 2020. https://www.imf.org/external/datamapper/ GGXCNL_NGDP@WEO/RUS

International Monetary Fund. "Real GDP growth: Annual percent change." IMF DataMapper. April 2020. https://www.imf.org/external/datamapper/NGDP_RPCH@WEO/RUS/EU

Janjevic, Darko. "EU populists on Russia: Moving out of lockstep.” DW: Europe. June 3, 2018. https://www.dw.com/en/eu-populists-on-russia-moving-out-of-lockstep/g-44059491

Jones, Timothy. “German AfD parliamentarian could be under Russian influence: report.” $D W$ News. April 5, 2019. https://www.dw.com/en/german-afd-parliamentarian-could-be-underrussian-influence-report/a-48221119

Kim, Lucian, and Steve Inskeep. "Prisoner Exchange Is A Positive Sign In Russia-Ukraine War." NPR: Europe. December 30, 2019. https://www.npr.org/2019/12/30/792302167/prisonerexchange-is-a-positive-sign-in-russia-ukraine-war

Kiselyova, Maria, Carlos Garcia Rawlins, Tom Balmforth, Angus Berwick, Alison Williams, and Steve Orlofsky. "Russian military specialists arrive in Venezuela to service equipment: Interfax.” Reuters: World News. September 25, 2019. https://www.reuters.com/article/usrussia-venezuela-specialists/russian-military-specialists-arrive-in-venezuela-to-serviceequipment-interfax-idUSKBN1WA2FJ 
Korsunskaya, Darya, Polina Devitt, and Gareth Jones. "Russia's PM: we understand that sanctions pressure will continue." Reuters: World News. February 14, 2019. https:// www.reuters.com/article/us-usa-russia-sanctions-pm/russias-pm-we-understand-thatsanctions-pressure-will-continue-idUSKCN1Q3189

Korsunskaya, Darya, and Tom Balmforth. "Russia lands nuclear bombers in Africa as Putin hosts continent's leaders." Reuters: World News. October 23, 2019. https://www.reuters.com/ article/us-russia-africa/russia-lands-nuclear-bombers-in-africa-as-putin-hosts-continentsleaders-idUSKBN1X21NS

Kramer, Andrew. "Ukrainian Pilot, Nadiya Savchenko, Is Exchanged for 2 Russian Prisoners." The New York Times. May 25, 2016. https:/www.nytimes.com/2016/05/26/world/europe/ ukraine-russia-prisoner-swap.html

Kraatz, Susanne. "The Russian Embargo: Impact on the Economic and Employment Situation in the EU." Policy Department A: Economy and Scientific Policy. PE 536.291. European Parliament. October 2014. https://www.europarl.europa.eu/RegData/etudes/BRIE/ 2014/536291/IPOL_BRI(2014)536291_EN.pdf

Kroet, Cynthia. "Merkel: EU will lift Russia sanctions when Minsk accords implemented." Politico. February 5, 2017. https://www.politico.eu/article/merkel-eu-will-lift-russiasanctions-when-minsk-accords-implemented/

Kuchay, Bilal. "Russian S-400 missile delivery to India by end of 2021: Official." Al-Jazeera: News Russia. February 5, 2020. https://www.aljazeera.com/news/2020/02/russian-400$\underline{\text { missile-delivery-india-2021-official-200205082528342.html }}$

Kurmanaev, Anatoly. "Russia Central Bank Raises Interest Rates in Effort to Stem Economic Risks.” Wall Street Journal. December 14, 2018. https://www.wsj.com/articles/russiacentral-bank-raises-interest-rates-in-effort-to-stem-inflation-11544787610

Kurmanaev, Anatoly. "Why Is Russia Helping Venezuela?” The New York Times. March 8, 2019. https://www.nytimes.com/2019/03/08/world/americas/russia-venezuela-maduroputin.html

Ladislaw, Sarah, Sigal Mandelker, and Dr. John Hamre. “Are Sanctions Working?” Welcome and Opening Remarks + Keynote. Center for Strategic and International Studies. July 31, 2019. https://csis-prod.s3 amazonaws.com/s3fs-public/event/ 190731 sanctions working keynote.pdf?qHZAjihZf rSCCznwTylR5HWDghkw4v

Levada-Tsentr. "Avgustovskie retying odobreniya." Press release. August 6, 2014. https:// web.archive.org/web/20140808235142/http://www.levada.ru/06-08-2014/avgustovskiereitingi-odobreniya

Levada-Tsentr. "Mezhdunarodnye otnosheniya i sanktsii." Ot mneniy - $k$ ponimaniyu. Press release. June 15, 2017. https://www.levada.ru/2017/06/15/16137/ 
Liangyu. "China, Russia agree to upgrade relations for new era." Xinhua. June 6, 2019. http:// www.xinhuanet.com/english/2019-06/06/c 138119879.htm

Liik, Kadri. "Winning the Normative War with Russia: An EU-Russia Power Audit." European Council on Foreign Relations. May 2018. https://www.ecfr.eu/page/-/EURUSSIA_POWER_AUDIT_.pdf

Lister, Tim. "Turkey bought Russian S-400 missiles designed to down NATO planes. For the US, that's a problem." CNN World. July 13, 2019. https://www.cnn.com/2019/07/13/europe/ turkey-russia-missiles-nato-analysis-intl/index.html

Luhn, Alec. "Russia signs 30-year deal worth $\$ 400$ bn to deliver gas to China." The Guardian. May 21, 2014. https://www.theguardian.com/world/2014/may/21/russia-30-year-400bngas-deal-china

Luhn, Alec. "Russia's campaign in Syria leads to arms sale windfall." The Guardian. March 29, 2016. https://www.theguardian.com/world/2016/mar/29/russias-campaign-in-syria-leadsto-arms-sale-windfall

Macrotrends. "Crude Oil Prices - 70 Year Historical Chart." Based on West Texas Intermediate (WTI or NYMEX) crude oil prices per barrel. 2020. https://www.macrotrends.net/1369/ crude-oil-price-history-chart

Magnitogorskiy metallurgicheskiy kombinat. “O kompanii.” Glavnaya. 2020. http://mmk.ru/ $\underline{\text { about/ }}$

Marcus, Jonathan. "Russia S-400 Syria missile deployment sends robust signal." BBC News: Europe. December 1, 2015. https://www.bbc.com/news/world-europe-34976537

Melander, Ingrid, and Brian Love. "France says U.S. sanctions on Iran, Russia look illegal." Reuters: Politics. July 26, 2017. https://www.reuters.com/article/us-usa-trump-russiafrance-idUSKBN1AB1MS?il=0

Meyer, Henry. "Russia Rejects Extending Iran Arms Embargo, Defying U.S.” Bloomberg . December 27, 2019. https://www.bloomberg.com/news/articles/2019-12-27/russia-rejectsextending-iran-arms-embargo-defies-u-s-pressure

Mindock, Clark. "Europe 'stands ready to act' if US sanctions on Russia affect its oil and gas supplies.”Independent. July 26, 2017. https://www.independent.co.uk/news/world/ americas/us-politics/us-russia-sanctions-latest-europe-ready-to-act-jean-claude-junckerenergy-security-america-first-a 7861851.html

Miller, Christopher. "Explainer: What Is The Steinmeier Formula -- And Did Zelenskiy Just Capitulate To Moscow?" RadioFreeEurope. October 2, 2019. https://www.rferl.org/a/ what-is-the-steinmeier-formula-and-did-zelenskiy-just-capitulate-to-moscow-/ 30195593.html 
MINFIN Rossii. “Federalniy Byudzhet.” Statistika. 2020. https://www.minfin.ru/ru/statistics/ fedbud/

Ministere de L'Intérieur de France. “Résultats des élections législatives 2012.” Legislatives. June 17, 2012. https://www.interieur.gouv.fr/Elections/Les-resultats/Legislatives/ elecresult__LG2012/(path)/LG2012/index.html

Ministry of Foreign Affairs of Republic of Slovenia. "15th Session of the Intergovernmental Slovenian-Russian Commission for Economic Cooperation.” News release. June 14, 2019. https://www.gov.si/en/news/2019-06-14-15th-session-of-the-intergovernmental-slovenianrussian-commission-for-economic-cooperation/

Moscow Times. "Crimean Economy Named Fastest Growing in Russia." Moscow Times. June 3, 2019. https://www.themoscowtimes.com/2019/06/03/crimean-economy-named-fastestgrowing-in-russia-a65851

Moscow Times. "Half of Russians Say They'll Never Live to See a Decent Salary - Survey." Moscow Times. April 10, 2019. https://www.themoscowtimes.com/2019/04/10/half-ofrussians-say-theyll-never-live-to-see-a-decent-salary-survey-a65173

Moscow Times. "India's Russian Arms Purchases Hit 'Breakthrough' \$14.5Bln, Official Says." Moscow Times. September 5, 2019. https://www.themoscowtimes.com/2019/09/05/indiasrussian-arms-purchases-hit-breakthrough-145bln-official-says-a67153

Moscow Times. "Iran 'Won't Be Alone' If U.S. Attacks, Russian Official Says.” Moscow Times . June 26, 2019. https://www.themoscowtimes.com/2019/06/26/iran-wont-be-alone-if-usattacks-russian-official-says-a66169

Moscow Times. "Medvedev Says 'Evil' Sanctions Could Lead to Defense Spending Hike." Moscow Times. July 17, 2014. https://www.themoscowtimes.com/2014/07/17/medvedevsays-evil-sanctions-could-lead-to-defense-spending-hike-a37414

Moscow Times. "Putin's Approval Rating Steadily Increases to 68\%, Survey Says." Moscow Times. July 5, 2019. https://www.themoscowtimes.com/2019/07/05/putins-approvalrating-steadily-increases-to-68-survey-says-a66290

Moscow Times. "Russia Extends Austria Gas Deal to 2040 After Putin's Visit." Moscow Times. June 6, 2018. https://www.themoscowtimes.com/2018/06/06/russia-extends-austria-gasdeal-to-2040-after-putins-visit-a61695

Moscow Times. "State TV Still Biggest and Most Trusted News Source for Russians - Poll." Moscow Times. April 18, 2018. https://www.themoscowtimes.com/2018/04/18/state-tvstill-biggest-most-trusted-news-source-russians-poll-a61205

Murphy, Francois, Andrew Osborn, and Tom Heneghan. "Austrian far right signs deal with Putin's party, touts Trump ties.” Reuters: World News. December 19, 2016. https:// 
www.reuters.com/article/us-austria-farright-russia/austrian-far-right-signs-deal-withputins-party-touts-trump-ties-idUSKBN1481MJ

Nardelli, Alberto, Jennifer Rankin and George Arnett. "Vladimir Putin's approval rating at record levels." The Guardian. July 23, 2015. https://www.theguardian.com/world/datablog/2015/ jul/23/vladimir-putins-approval-rating-at-record-levels

Nord Stream 2. "Nord Stream 2 is a European collaboration." Nord Stream 2. 2020. https:// www.nord-stream 2.com/nord-stream-2-is-a-european-collaboration/

Nornickel. "Novosti." O Kompanii. 2020. https://www.nornickel.ru/

North Atlantic Treaty Organization. "NATO Mediterranean Dialogue.” Topics. February 13, 2015. https://www.nato.int/cps/en/natohq/topics_60021.htm?

North Atlantic Treaty Organization. "Relations with the European Union." Topics. March 23, 2020. https://www.nato.int/cps/en/natohq/topics_49217.htm

Novatek. "O kampanii." Glavnaya stranitsa: Kompaniya.2020. http://www.novatek.ru/ru/about/ company/

Nuclear Threat Initiative. "Overview.” Venezuela. July 2016. https://www.nti.org/learn/countries/ venezuela/

OECD. "Where: Global Reach." OECD Development Center. 2020. https://www.oecd.org/about/ members-and-partners/

Office for Democratic Institutions and Human Rights. "Ukraine: Presidential Election 31 March and 21 April 2019." ODIHR Election Observation Mission Final Report. Organization for Security and Co-operation in Europe. November 20, 2019. https://www.osce.org/odihr/ elections/ukraine/439631?download=true

Oliphant, Roland. "Russia introduces ban on most food imports from EU and US." The Telegraph. August 7, 2014. https://www.telegraph.co.uk/news/worldnews/europe/russia/ $\underline{11019215 / R u s s i a-i n t r o d u c e s-b a n-o n-m o s t-f o o d-i m p o r t s-f r o m-E U-a n d-U S . h t m l ~}$

One hundred fifteenth Congress of the United States of America. "Countering America's Adversaries Through Sanctions Act.” Authenticated U.S. Government Information GPO. January 3, 2017. https://www.treasury.gov/resource-center/sanctions/Programs/ Documents/hr3364 pl115-44.pdf

Organisation for Economic Co-operation and Development. "General government debt: Total Percent of GDP." OECD Data. 2018. https://data.oecd.org/gga/general-governmentdebt.htm

Organization for Security and Co-operation in Europe. Kompleks mer po vypolneniu Minskikh soglasheniy. September 5, 2014. https://www.osce.org/ru/cio/140221?download=true 
Organization for Security and Co-operation in Europe. Protokol: po itogam konsultatsiy Trekhstoronneiy knotaktnoiy gruppy otnositelno sovmestnykh shagov, napravlennykh na implmentaziu Mirnogo plana Prezidenta Ukrainy P. Poroshenko i initsiativ Prezidenta Rossii V. Putina. February 12, 2015. https://www.osce.org/ru/home/123258? $\underline{\text { download=true }}$

Orthodox Church. "Orthodox Patriarch of Moscow blesses President Putin.” Russia: Pravaslavnaya Tserkov. Youtube. May 7, 2018. https://www.youtube.com/watch? $\mathrm{v}=2 \mathrm{y} 2 \mathrm{f} 4 \mathrm{vGza} 64$

OSCE Chairmanship. "OSCE Chair says Crimean referendum in its current form is illegal and calls for alternative ways to address the Crimean issue." Organization for Security and Co-operation in Europe. March 11, 2014. https://www.osce.org/cio/116313

Paraskova, Tsvetana. "Russia's oil revenue is about to soar." Business Insider. May 14, 2018. https://www.businessinsider.com/russia-oil-revenue-about-to-soar-2018-5

Parry, Nat, and Thomas Rymer. "Russian presidential election well administered, but characterized by restrictions on fundamental freedoms, lack of genuine competition, international observers say." Office for Democratic Institutions and Human Rights. Organization for Security and Co-operation in Europe. March 19, 2018. https:// www.osce.org/odihr/elections/375661

Perviy Kanal. “Gost Anton Siluanov. Pravo na spravedlivost. Vypusk ot 22.10.2019.” Russia: Perviy Kanal. Youtube. December 2, 2019. https://www.youtube.com/watch? $\underline{\mathrm{v}=\mathrm{URxopc} 6 \mathrm{JDfg}}$

Perviy Kanal. "Posle DRSMD. Vremya Pokzhet. 05.03.2019.” Russia: Perviy Kanal. Youtube. March 5, 2019. https://www.youtube.com/watch?v=FpOkg3qnrqc

Perviy Kanal. "Slovo pastyrya. Efir ot 15 fevralya 2020 goda. Izbrannoe." Russia: Perviy Kanal. Youtube. February 15, 2020. https://www.youtube.com/watch?v=W-DsnS8Q2ug

Pickrell, Ryan. "Moscow to arm Syria with advanced anti-aircraft missiles after a massive air battle downed a Russian plane." Business Insider. September 24, 2018. https:// www.businessinsider.com/syria-to-get-russian-s-300-weapons-after-accidental-shootdown-2018-9

Postoyannoe predstavitelstvo Rossyskoy Federatsii pri Evropeyskom soyuze. "Torgovlya." Kratkiy obzor otnosheniy: Sfery sotrudnichestva. 2020. https://russiaeu.ru/ru/torgovlya

President of Russia. "Security Council meeting." News: Events. July 3, 2015. http:// en.kremlin.ru/events/president/news/49862

Prezident Rossii. "Mezhdunardnyi forum 'Odin poyas, odin put.” Novosti: Sobytiya . April 26, 2019. http://kremlin.ru/events/president/news/60378 
Prezident Rossii. "Podpisan Dogovor o prinyatii Respubliki Krym v Rossiyskyu Federatsiyu." Novosti: Sobytiya. March 18, 2014. http://kremlin.ru/events/president/news/20604

Prezident Rossii. "Poslanie Prezidenta Federalnomu Sobraniyu." Novosti: Sobytiya. March 1, 2018. http://kremlin.ru/events/president/news/56957

Prezident Rossii. "Rossiysko-turetskie peregovory.” Novosti: Sobytiya. March 5, 2020. http:// kremlin.ru/events/president/news/62936

Prezident Rossii. "Soveshanie o deystviyakh Vooruzhiennykh Sil Rossii v Sirii." Novosti: Sobytiya. November 17, 2015. http://kremlin.ru/events/president/news/50714

Prezident Rossii. "Soveshanie o rukovodstvom Minoborony o deystviyakh Vooruzhiennykh Sil Rossii v Sirii.” Novosti: Sobytiya. November 20, 2015. http://kremlin.ru/events/president/ news/50737

Prezident Rossii. "Soveshanie s chlenami Pravitelstva.” Novosti: Sobytiya. August 27, 2014. http://kremlin.ru/events/president/news/46499

Prezident Rossii. “Telefonniy razgovor s Prezidentom Sirii Basharom Asadom.” Novosti: Sobytiya. March 6, 2020. http://kremlin.ru/events/president/news/62956

Prezident Rossii. “Telefonniy razgovor s Prezidentom Ukrainy Vladimirom Zelenskim.” Novosti: Sobytiya. December 31, 2019. http://kremlin.ru/events/president/news/62532

Prezident Rossii. "Ukaz o primenenii otdelnykh spetsualnykh ekonomicheskikh mer v tselyakh obespecheniya bezopasnosti Rossiyskoy Federatsii." Novosti: Sobytiya. August 6, 2014. http://kremlin.ru/events/president/news/46404

Prezident Rossii. "Utverzhdena Strategiya ekonomicheskoy bezopasnosti Rossii do 2030 goda." Novosti: Dokumenty. May 15, 2017. http://kremlin.ru/acts/news/54497

Prezident Rossii. "Vladimir Putin podderzhal predlozheniye Viktora Medvedchuka ob obměna plennymi mezhdu Ukrainoy i Donetskoy i Luganskoy respublikami." Novosti: Sobytiya. November 15, 2017. http://kremlin.ru/events/president/news/56095

Prezident Rossii. "Vladimir Putin postal Siriyskuyu Arabskuyu Respubliku." Novosti: Sobytiya. January 7, 2020. http://kremlin.ru/events/president/news/62545

Prezident Rossii. "Vstrecha litero BRICS.” Novosti: Sobytiya. November 14, 2019. http:// kremlin.ru/events/president/news/62045

Prezident Rossii. "Vstrecha s chlenami fraktsii politicheskikh partiy v Gosudarstvennoy Dume." Novosti: Sobytiya. August 14, 2014. http://kremlin.ru/events/president/news/46451

Prezident Rossii. "Vstrecha s Marin Le Pen.” Novosti: Sobytiya. March 24, 2017. http:// kremlin.ru/events/president/news/54102 
Prezident Rossii. "Vstrecha s Premier-ministrom Vengrii Viktorom Orbanom." Novosti: Sobytiya. August 28, 2017. http://kremlin.ru/events/president/news/55444

Prezident Rossii. "Vstrecha s Premier-ministrom Vengrii Viktorom Orbanom." Novosti: Sobytiya. July 15, 2018. http://kremlin.ru/events/president/news/58003

Prezident Rossii. "Vstrecha s Prezidentem Sirii Basharom Asadom.” Novosti: Sobytiya. October 21, 2015. http://kremlin.ru/events/president/news/50533

Prezident Rossii. “Zasedaniye Soveta Bezopasnosti.” Novosti: Sobytiya. July 3, 2015. http:// kremlin.ru/events/president/news/49862

Prezidentskaya Biblioteka. "O strategii ekonomicheskoy bezopasnosti Rossiyskoy Federatsii na period do 2030 goda." Ukaz Prezidenta Rossiyskoy Federatsii no. 208. May 13, 2017. https://www.prlib.ru/node/681513

Radio New Zealand. "NZ govt considers further measures against Russia.” Politics/Economy. March 17, 2018. https://www.rnz.co.nz/news/political/352731/nz-govt-considers-furthermeasures-against-russia

RadioFreeEurope. "Russia Blasts New U.S., EU Sanctions As 'Primitive' Measures.” Russia. July 17, 2014. https://www.rferl.org/a/russia-condemns-us-eu-sanctions-ukraine/ 25460171.html

RadioFreeEurope. "Slovenian PM Sarec In Moscow To Discuss Economic Cooperation." RadioFreeEurope. September 10, 2019. https://www.rferl.org/a/slovenia-prime-ministersarec-russia-medvedev-moscow/30156156.html

Ray, Julie, and Neli Esipova. "Economic Problems, Corruption Fail to Dent Putin's Image." GALLUP: News. March 28, 2017. https://news.gallup.com/poll/207491/economicproblems-corruption-fail-dent-putin-image.aspx

Razumkov Tsentr. "Gromadska dumka pro situatsiu na Donbasi ta shlyahi vidnovlennya syverenitetu Ukraini nad okypovanimi teritoriyami.” Razumkov Tsentr. October 11, 2019. http://razumkov.org.ua/napriamky/sotsiologichni-doslidzhennia/gromadska-dumka-prosytuatsiiu-na-donbasi-ta-shliakhy-vidnovlennia-suverenitetu-ukrainy-nad-okupovanymyterytoriiamy

Utenriksdepartementet. "Tiltak mot personer som truer Ukrainas territorielle integritet." Regjeringen. March 21, 2014. https://www.regjeringen.no/no/aktuelt/tiltak-ukraina/ $\underline{\text { id753686/ }}$

Reid, David. "Russian energy minister says tension in the Persian Gulf is not the fault of Iran." CNBC: Oil. July 2, 2019. https://www.cnbc.com/2019/07/02/russia-energy-ministernovak-calls-sanctions-against-iran-unlawful.html 
Reilhac, Gilbert. "Council of Europe readmits Russia, five years after suspension over Crimea." Reuters: World News. June 25, 2019. https://www.reuters.com/article/us-europe-rightscouncil-russia/council-of-europe-readmits-russia-five-years-after-suspension-over-crimeaidUSKCN1TQ1VL

Rettman, Andrew. "Russia blacklist of EU names 'unjustified'." EUobserver: Foreign Affairs. May 31, 2015. https://euobserver.com/foreign/128900

Reuters. "Danish minister calls for EU-wide sanctions on Russia over Azov Sea." World news. January 29, 2019. https://www.reuters.com/article/us-ukraine-crisis-eu-russia/danishminister-calls-for-eu-wide-sanctions-on-russia-over-azov-sea-idUSKCN1PN0L8

Reuters. "EU sanctions Skripal suspects, Russia calls move groundless.” World news. January 21, 2019. https://www.reuters.com/article/us-britain-russia/eu-sanctions-skripal-suspectsrussia-calls-move-groundless-idUSKCN1PF18I

Reyting. "Stavlennya Ukraintsiv do virishennya pitannia okypovanix teritoriy." The Rating Group. October 2, 2019. http://ratinggroup.ua/research/ukraine/ otnoshenie_ukraincev_k_resheniyu_voprosa_okkupirovannyh_territoriy.html

RIA Novosti. "Mezhgosudarstvennye otnosheniya Rossii i Kitaya." RIA Novosti. November, 13, 2019. https://ria.ru/20191113/1560810249.html

Rosneft. "Igor Sechin.” Korporative upravlenie: Upravlenie. 2020. https://www.rosneft.ru/ governance/corpmanagement/item/746/

Rosneft. “O kampanii.” Glavnaya stranitsa.2020. https://www.rosneft.ru/about/

Rosneft. "“Rosneft' segodnya.” Glavnaya stranitsa: o kampanii. 2020. https://www.rosneft.ru/ about/Glance/

Rostec. "O kampanii.” Glavnaya. 2020. https://rostec.ru/about/

Rosobornexport. "Rukovodstvo.” Status. 2020. http://roe.ru/rosoboronexport/rukovodstvo/

Rosobornexport. "Strategia.” Status. 2020. http://roe.ru/rosoboronexport/strategy/

Rosselkhozbank. "Missiya." O banke. 2020. https://www.rshb.ru/about/mission/

Rosselkhozbank. "Strategiya AO 'Rosselkhozbank' do 2020 goda: Osnovnye polozheniya.” Aktsianoernoye obshestvo 'Rossiyskiy Selskokhozyaystveniy bank'. April 2016. https:// www.rshb.ru/download-file/155891/strategy2020.pdf

Rossiya 24. "60 minut. Novoe tok-shoy s Olgoy Skabeevoy I Evgeniem Popobym ot 17.07.2018.” Russia: Rossiya 1. Youtube. July 17, 2018. https://www.youtube.com/watch? v=wmgHe 3 feoPk 
Rossiya 24. "Ministr finansov: Rossiya nayuchena sankstiyami SSHA - doly dollara byudet snizhena - Rossiya 24." Russia: Rossiya 1. Youtube. December 11, 2019. youtube.com/ $\underline{\text { watch? }}=\mathrm{Xb9gzzBPt} 8$

Rossiya 24. "Putin. Film Andreya Kondrashova. Polnoe video." Russia: Rossiya 1. Youtube. March 24, 2018. https://www.youtube.com/watch?v=y9Pu0yrOwKI

Rossiya 24. "Rossiya i Iran vyshli na novyi uroven sotrudnechestva." Russia: Rossiya 1. Youtube. March 28, 2017. https://www.youtube.com/watch?v=Sjn0HQGSi8E

Rossiya 24. "Vesti nedeli s Dmitriem Kiselyovym to 14.04.19." Russia: Rossiya 1. Youtube. April 14, 2019. https://www.youtube.com/watch?v=jf1 Z7Qdre0

Roth, Andrew. "Kerch strait confrontation: what happened and why does it matter?" The Guardian. November 27, 2018. https://www.theguardian.com/world/2018/nov/27/kerchstrait-confrontation-what-happened-ukrainian-russia-crimea

Roth, Andrew. "Putin opens 12-mile bridge between Crimea and Russian mainland." The Guardian. May 15, 2018. https://www.theguardian.com/world/2018/may/15/putin-opensbridge-between-crimea-and-russian-mainland

Roth, Andrew. "Russia acknowledges presence of troops in Venezuela." The Guardian. March 28, 2019. https://www.theguardian.com/world/2019/mar/28/russian-troops-landedcaracas-talks-venezuela-envoy-military

Roth, Andrew. "Russian MPs pass unpopular bill to raise pension age." The Guardian. September 27, 2018. https://www.theguardian.com/world/2018/sep/27/russian-mps-passunpopular-bill-to-raise-pension-age

Roth, Andrew. "Vladimir Putin secures record win in Russian presidential election." The Guardian. March 19, 2018. https://www.theguardian.com/world/2018/mar/19/vladimirputin-secures-record-win-in-russian-presidential-election

RUPTLY. "France: Putin and Zelensky praise 'positive' meeting and 'thaw' in relations." Russia: $R T$. Youtube. December 9, 2019. https://www.youtube.com/watch?v=AMwQzfDENFU

RUPTLY. "Russia: Moscow and Kiev finalising negotiations on large-scale prisoner swap Putin.” Russia: RT. Youtube. December 9, 2019. https://www.youtube.com/watch? $\underline{\mathrm{v}=\mathrm{BHeEAknHMGs}}$

RUPTLY. "Russia: Putin discusses sanctions, Trump's Huawei ban at 'Direct Line'.” Russia: RT. Youtube. June 20, 2019. https://www.youtube.com/watch?v=1KKoXIuo c8

RUPTLY. "Russia: Putin waters down unpopular retirement age increase." Russia: RT. Youtube. August 29, 2018. https://www.youtube.com/watch?v=Lqcmraft0mI 
RUPTLY. "Russia: Stricter anti-Russia sanctions introduced 'to contain' Russia - Putin." Russia: $R T$. Youtube. June 15, 2017. https://www.youtube.com/watch?v=53iEABP660s

RUPTLY. "Russia: United Russia and Austria's FPO sign cooperation agreement.” Russia: RT. Youtube. December 19, 2016. https://www.youtube.com/watch?v=ei 5hKUkmVk

RUPTLY. "Slovenia: Sanctions have 'negative impact' on EU and Russia - PM Cerar tells Medvedev." Russia: RT. Youtube. July 27, 2015. https://www.youtube.com/watch? $\underline{\mathrm{v}=\mathrm{K} 3 \mathrm{ixo6reuPk}}$

Ruskaya Pravoslavnaya Tserkov. "“Slovo pastyrya'. Vypusk ot 5 dekabrya 2015 goda.” Programma "Slovo pastyrya”. December 8, 2015. http://www.patriarchia.ru/db/text/ $\underline{4290996 . h t m l}$

Russia Insight. "BREAKING! Putin Meets Turkey's Erdogan In Moscow!” Russia: Rossiya 24. Youtube. March 5, 2020. https://www.youtube.com/watch?v=x01aNBWIuFw

Russia Insight. "Putin Gets Blessed By Head Of Russian Orthodox Church Kirill After Presidential Inauguration.” Russia: Rossiya 24. Youtube. May 7, 2018. https:// www.youtube.com/watch?v=R1ViaaeFjdo

Russia Insight. "WHAT SANCTIONS!? Putin Signs First Mercedes-Benz Off The Production Line in New Russian Plant." Russia: Rossiya 1. Youtube. April 5, 2019. https:// www.youtube.com/watch?v=ED0zYbWbyJc\&list=ULQs1zvjKaKPQ\&index=634

Russian Export Center. "Vnesheconombank.” About REC. 2020. https://www.exportcenter.ru/en/ company/partners/veb/

Russian Export Center. “AO 'Rossiyskiy eksortnyi tsentr’.” About tsentre. 2020. https:// www.exportcenter.ru/company/

"Russian National Security Strategy, December 2015 - Full-text Translation.” Approved by Russian Federation Presidential Edict 683. December 31, 2015. http://www.ieee.es/ Galerias/fichero/OtrasPublicaciones/Internacional/2016/Russian-National-SecurityStrategy-31Dec2015.pdf

Russell, Martin. "EU sanctions: A key foreign and security policy instrument." EPRS / European Parliamentary Research Service. May 2018. https://www.europarl.europa.eu/RegData/ etudes/BRIE/2018/621870/EPRS BRI(2018)621870 EN.pdf

Russell, Martin. "Sanctions over Ukraine: Impact on Russia.” EPRS / European Parliamentary Research Service. January 2018. https://www.europarl.europa.eu/RegData/etudes/BRIE/ 2018/614665/EPRS_BRI(2018)614665_EN.pdf

Schaart, Eline. "Dutch PM Rutte: EU must get tough on sanctions.” Politico. February 13, 2019. https://www.politico.eu/article/dutch-pm-rutte-eu-must-get-tough-on-sanctions/ 
Segodnya. "Putin provel vstrechu s liderom Irana na sammite SHOS." Russia: NTV. Youtube. June 14, 2019. https://www.youtube.com/watch?v=qEY5KLxYazg

Severstal. “O kompanii.” Severstal v tsifrakh. 2020. https://www.severstal.com/rus/about/

Seymat, Thomas. "The complete blacklist of EU officials banned from Russia.” Euronews. June 2, 2015. https://www.euronews.com/2015/06/02/the-complete-blacklist-of-europeanofficials-barred-from-entering-russia-putin

Shapovalov, Aleksey. "Gordye platyat vsem.” Kommersant. October 29, 2019. https:// www.kommersant.ru/doc/4141418

Signe, Landry. "Vladimir Putin is resetting Russia's Africa agenda to counter the US and China." Quartz Africa. October 22, 2019. https://qz.com/africa/1732316/putin-resets-russiasafrica-agenda-to-counter-china-us/

Simon, Zoltan. "How Viktor Orban's Populism May Face Backlash in Budapest." Bloomberg . October 9, 2019. https://www.bloomberg.com/news/articles/2019-10-09/how-orban-spopulism-may-face-backlash-in-budapest-quicktake

Sistema. "O korporatsii.” Glavnaya. 2020. https://sistema.ru/about

Smeets, Maarten. "Can Economic Sanctions Be Effective?" Economic Research and Statistics Division. World Trade Organization. March 15, 2018. https://www.wto.org/english/res e/ reser_e/ersd201803_e.pdf

Sovet Federatsii. "Sovet Federatsii dal soglasie na ispolzovaniye Vooruzhennykh Sil Rossii na territorie Ukrainy." Vse Novosti. March 1, 2014. http://council.gov.ru/events/news/39851/

"Soviet-Syrian Treaty of Friendship and Co-operation 8 October 1980." Journal of Survival: Global Politics and Strategy 23, no. 1 (2008): 43-44. https://www.tandfonline.com/doi/ abs/10.1080/00396338108441945?journalCode=tsur20

Spestialnaya monitoringovaya missiya v Ukraine."Tendenstii i nabludeniya 2019." Organizatsiya po bezopastnosti i sotrudnichestvu v Evrope. 2019. https://www.osce.org/ru/specialmonitoring-mission-to-ukraine/444748?download=true

Spestialnaya monitoringovaya missiya v Ukraine."Tematucheskiy Otchet - Ogranicheniya svobody peredvizheniya i drugie prepyatstviya v vepolnenii mandata CMM: Yanvar-Iun 2019." Organizatsiya po bezopastnosti i sotrudnichestvu v Evrope. September 2019. https://www.osce.org/ru/special-monitoring-mission-to-ukraine/429479?download=true

State Secretariat for Economic Affairs SECO. "Smart sanctions - targeted sanctions." Swiss Confederation. March 24, 2017. https://www.seco.admin.ch/seco/en/home/ Aussenwirtschaftspolitik Wirtschaftliche Zusammenarbeit/Wirtschaftsbeziehungen/ exportkontrollen-und-sanktionen/sanktionen-embargos/smart-sanctions--gezieltesanktionen.html 
Statista Research Department. "Russian federal budget oil and gas revenue 2016-2019." Statista: Fossil Fuels. February 2020. https://www.statista.com/statistics/1028682/russia-federalbudget-oil-and-gas-revenue/

Statista Research Department. "Vladimir Putin's approval rating in Russia 2000-2020." Society: Politics and Government. May 8, 2020. https://www.statista.com/statistics/896181/putinapproval-rating-russia/

Statistics Canada. "Income of individuals by age group, sex and income source, Canada, provinces and selected census metropolitan areas." Government of Canada. May 21, 2020. https://www150.statcan.gc.ca/t1/tbl1/en/tv.action? pid=1110023901\&pickMembers $\% 5 \mathrm{~B} 0 \% 5 \mathrm{D}=1.1 \&$ pickMembers $\% 5 \mathrm{~B} 1 \% 5 \mathrm{D}=2.1 \&$ pickMe mbers $\% 5 \mathrm{~B} 2 \% 5 \mathrm{D}=3.1 \&$ pickMembers $\% 5 \mathrm{~B} 3 \% 5 \mathrm{D}=4.1$

Stockholm International Peace Research Institute. "TIV of arms exports from Russia, 2000-2019.” SIPRI Arms Transfers Database. Generated May 21, 2020. http:// armstrade.sipri.org/armstrade/page/values.php

Stockholm International Peace Research Institute. "V 2018 Godu Mirovye Voennye Raskhody Vyrosli do \$1.8 trln.” Press release. April 29, 2019. https://www.sipri.org/sites/default/ files/2019-04/milex press release rus.pdf

Szczepański, Marcin. "Economic impact on the EU of sanctions over Ukraine conflict.” EPRS I European Parliamentary Research Service. October 2015. https:// www.europarl.europa.eu/RegData/etudes/BRIE/2015/569020/ EPRS BRI(2015)569020 EN.pdf

Tanas, Olga. "Putin Says Russia Seeks More Cooperation With BRICS Nations.” Bloomberg: Politics. July 26, 2018. https://www.bloomberg.com/news/articles/2018-07-26/putin-saysrussia-seeks-greater-cooperation-with-brics-nations

TASS. "Putin approves Russian economic security strategy until 2030." TASS Russian News Agency. May 15, 2017. https://tass.com/economy/945846

TASS. "Russia, Slovenia sign a number of cooperation documents." TASS: Russian News Agency. September 10, 2019. https://tass.com/politics/1077483

TASS. "Russia takes over the reins to chair BRICS in 2020." TASS: Russian News Agency. December 31, 2019. https://tass.com/politics/1105265

TASS, and Vladimir Putin. "20 Questions with Vladimir Putin. Putin on Ukraine.” Russia: TASS. Youtube. February 20, 2020. https://www.youtube.com/watch?v=NG6dxqwxGE4

TASS, and Vladimir Putin. "We Are the Same People' - Putin Discusses Relations with Ukraine.” Russia: RUPTLY. Youtube. February 21, 2020. https://www.youtube.com/ watch? $\mathrm{v}=\mathrm{g} 8 \mathrm{Ek} \_$tRBDg 
Tcherneva, Vessela. "View from Sofia: A difficult choice between Russia and the West." European Council on Foreign Relations. March 9, 2015. https://www.ecfr.eu/article/ commentary_view_from_sofia_a_difficult_choice_between_russia_and_the_west31

Teffer, Peter. "Wilders says Russia is 'no enemy' ahead of Moscow visit." EUobserver: Foreign Affairs. November 23, 2017. https://euobserver.com/foreign/139996

Transneft. “Komaniya.” Glavnya. 2020. https://www.transneft.ru/about/

Transoil. "Osnovnye fakty i pokazateli." O kampanii. 2020. http://transoil.com/about/facts/

Tsvetkova, Maria, and Anton Zverev. "Ghost soldiers: the Russians secretly dying for the Kremlin in Syria." Reuters: World News. November 3, 2016. https://www.reuters.com/ article/us-mideast-crisis-syria-russia-insight-idUSKBN12Y0M6

UA 112. "Vyshynsky appointed as executive director of one of Russian mass media." UA 112. October 7, 2019. https://112.international/politics/vyshynsky-appointed-as-executivedirector-of-one-of-russian-mass-media-44295.html

UATV English. "Merkel-Putin Meeting: Ukraine, Nord Stream 2, Syria on the Agenda." Ukraine: UATV. Youtube. August 19, 2018. https://www.youtube.com/watch? $\mathrm{v}=\mathrm{ieID} 7 \mathrm{XvVbW8}$

UN News. "Political solution 'long overdue' to protect the children of eastern Ukraine." United Nations. December 2, 2019. https://news.un.org/en/story/2019/12/1052521

UN News. "Top UN court will consider Ukraine allegations against Russia of treaty violations." United Nations. November 8, 2019. https://news.un.org/en/story/2019/11/1051001

UN News. "UN chief notes 'with concern' report holding Russia liable for downing airliner." United Nations. May 25, 2018. https://news.un.org/en/story/2018/05/1010741

UN News. "Venezuela: Competing US, Russia resolutions fail to pass in Security Council." United Nations. February 28, 2019. https://news.un.org/en/story/2019/02/1033832

UNIAN. "EU calls on all UN member states to join sanctions against Russia." Politics. March 18, 2016. https://www.unian.info/politics/1293769-eu-calls-on-all-un-member-states-tojoin-sanctions-against-russia.html

UNIAN. "Sweden to keep putting pressure on Russia through sanctions." Politics. November 5, 2019. https://www.unian.info/politics/10744236-sweden-to-keep-putting-pressure-onrussia-through-sanctions.html

United Nations Conference on Trade and Development. "Agreement on Partnership and Cooperation Establishing a Partnership between the European Communities and Their Member States, of One Part, and Russia, of the Other Part." International Investment Agreements Navigator: EC-Russia PCA. 2020. https://investmentpolicy.unctad.org/ 
international-investment-agreements/treaties/treaties-with-investment-provisions/3127/ecrussia-pca

United Nations Security Council. “2231 List.” Resolution 2231 (2015) on Iran Nuclear Issue. 2020. https://www.un.org/securitycouncil/content/2231/list

United Nations Security Council. "Upcoming Period Will Be Crucial to Resolution of Conflict in Ukraine, International Officials Tell Security Council.” Meetings Coverage: 8726th meeting SC/14112. February 18, 2020. https://www.un.org/press/en/2020/sc14112.doc.htm

United Nations Statistics Division. "Russian Federation: Exports.” United Nations. August 2019. https://comtrade.un.org/labs/data-explorer/

United Nations. Charter of the United Nations. October 24, 1945. https://www.un.org/en/charterunited-nations/

United Nations General Assembly. "Situation of human rights in the Autonomous Republic of Crimea and the city of Sevastopol, Ukraine." Seventy-third session. A/RES/73/263. January 21, 2019. https://www.un.org/en/ga/search/view_doc.asp?symbol=A/RES/73/263

United Nations General Assembly, "Territorial integrity of Ukraine," Seventy-eight session, A/ RES/68/262. April 1, 2014. https://undocs.org/A/RES/68/262

United Nations. "Sanctions.” United Nations Security Council. 2020. https://www.un.org/ securitycouncil/sanctions/information

United Nations Aids. An Introduction to Triangulation. UNAIDS Monitoring and Evaluation Fundamentals. 2010. https://www.unaids.org/sites/default/files/sub_landing/files/10_4Intro-to-triangulation-MEF.pdf

United States Mission to the OSCE. "Ongoing Violations of OSCE Principles and Commitments by the Russian Federation and the Situation in Ukraine." PC.DEL/1475/14. December 18, 2014. https://www.osce.org/pc/134226?download=true

United States Government Accountability Office. "Economic Sanctions: Agencies Assess Impacts on Targets, and Studies Suggest Several Factors Contribute to Sanctions' Effectiveness." Report to Congressional Requesters. GAO-20-145. October, 2019. https:// www.gao.gov/assets/710/701891.pdf

US Department of the Treasury. " Ukraine-/Russia-related Sanctions.” Resource Center. March 20, 2020. https://www.treasury.gov/resource-center/sanctions/Programs/Pages/ ukraine.aspx

USDA Foreign Agricultural Service. "Russian Federation: Agricultural Economy and Policy Report." Global Agricultural Information Network. GAIN Report Number: RS1819. July 19, 2018. https://apps.fas.usda.gov/newgainapi/api/report/downloadreportbyfilename? 
filename=Agricultural\%20Economy\%20and\%20Policy\%20Report_Moscow_Russian\%20 Federation 7-19-2018.pdf

Vergine, Stefano. "Conte to Putin: EU sanctions on Russia make Italy 'sad'.” EUobserver: Foreign affairs. July 5, 2019. https://euobserver.com/foreign/145376

Vesti News. 'Dmitry Kiselyov: The West Has No Shame...They're Using the 'Chemical Weapon' Bogeyman Again.” Russia: Rossiya 1. Youtube. January 29, 2018. https:// www.youtube.com/watch?v=0adfDnFssgA

Vesti News. "Kiselev: West Seems Hell-Bent on Rewriting History and Making Everything Fake and Gay!" Russia: Rossiya 1. Youtube. February 23, 2019. https:// www.youtube.com/watch?v=0NgMJJWHyE8

Vesti News. "Vladimir Soloviev: West Mired in Bog of Russia-Related Hysteria With No Signs of Improvement.” Russia: Rossiya 1. Youtube. January 25, 2018. https:// www.youtube.com/watch?v=EWYU4ISe0h0

Vesti News. “'We Must Protect Our Identity’ - Putin Declares Russia Will Pursue Closer Ties With Orthodox Church.” Russia: Rossiya 1. Youtube. February 2, 2019. https:// www.youtube.com/watch?v=0WrTIHVvsas

Vesti News. "Western Food Sanctions Hit Russia Hard, Forced Domestic Industry to Expand, Grow and Adapt!" Russia: VGTRK. Youtube. January 27, 2019. https://www.youtube.com/ $\underline{\text { watch? }} \mathrm{v}=06$ ig $7 \mathrm{P} 703 \mathrm{cM}$

VTB. “Gruppa VTB.” O Gruppe VTB. 2020. https://www.vtb.ru/o-banke/gruppa-vtb/skhemagruppy/

Ward, Alex. "Why Russia just sent troops to Venezuela.” Vox. March 27, 2019. https:// www.vox.com/2019/3/27/18283807/venezuela-russia-troops-trump-maduro-guaido

Westcott, Ben. "Russia switches on gas mega-pipeline to China as Putin touts closer ties." CNN. December 3, 2019. https://www.cnn.com/2019/12/03/asia/china-russia-gas-pipeline-intl$\underline{\mathrm{hnk} / \mathrm{index} . \mathrm{html}}$

Wiederwald, Rupert. "Austria's far-right FPÖ party under scrutiny for ties to Russia." DW: News. May 21, 2019. https://www.dw.com/en/austrias-far-right-fp\%C3\%B6-party-underscrutiny-for-ties-to-russia/a-48822539

World Bank. "Export value index $(2000=100)$ - Russian Federation." Based on United Nations Conference on Trade and Development, Handbook of Statistics and data files, and International Monetary Fund, International Financial Statistics. 2019. https:// data.worldbank.org/indicator/TX.VAL.MRCH.XD.WD? cid=GPD 29\&end=2018\&locations=RU\&start=2001 
World Bank. "Foreign direct investment, net (BoP, current US\$) - Russian Federation.” Based on International Monetary Fund, Balance of Payments Statistics Yearbook and data files. 2019. https://data.worldbank.org/indicator/BN.KLT.DINV.CD? cid=GPD 29\&locations $=$ RU

World Bank. "GDP (current US\$) - Russian Federation.” Based on World Bank, national data, and OECD National Accounts data. 2019. https://data.worldbank.org/indicator/ NY.GDP.MKTP.CD?cid=GPD 29\&locations=RU

World Bank. "GNI (current US\$) - Iran, Islamic Rep., Sudan, Venezuela, RB, Myanmar, Egypt, Arab Rep., Tunisia, Libya." Based on World Bank, national data, and OECD National Accounts data. 2019. https://data.worldbank.org/indicator/NY.GNP.MKTP.CD? end=2018\&locations=IR-SD-VE-MM-EG-TN-

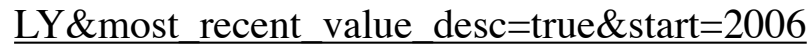

World Bank. "GNI (current US\$) - Russian Federation.” Based on World Bank, national data, and OECD National Accounts data. 2019. https://data.worldbank.org/indicator/ NY.GNP.MKTP.CD? $\underline{\text { end }=2018 \& \text { locations }=R U \& \text { most_recent_value_desc }=\text { true \&start }=2008}$

World Bank. “GNI (current US\$) - Russian Federation, United States, European Union.” Based on World Bank, national data, and OECD National Accounts data. 2019. https:// data.worldbank.org/indicator/NY.GNP.MKTP.CD?end=2018\&locations=RU-USEU\&most_recent_value_desc=true\&start=2006

World Bank. "Inflation, consumer prices (annual \%) - Russian Federation.” Based on International Monetary Fund, International Financial Statistics and data files. 2019. https:// data.worldbank.org/indicator/TX.VAL.MRCH.XD.WD? cid=GPD 29\&end=2018\&locations=RU\&start=2001

World Bank. "Net capital account (BoP, current US\$) - Russian Federation.” Based on International Monetary Fund, Balance of Payments Statistics Yearbook and data files. 2019. https://data.worldbank.org/indicator/BN.TRF.KOGT.CD? $\underline{\text { cid=GPD 29\&contextual }=\text { default\&end=2018\&locations }=\text { RU\&start }=1994 \& \text { view }=\text { chart }}$

World Economic Forum. "The Global Competitiveness Report 2013-2014.” Insight Report: Full Data Edition. 2013. http://www3.weforum.org/docs/ WEF_GlobalCompetitivenessReport_2013-14.pdf

World Economic Forum. "The Global Competitiveness Report 2014-2015." Insight Report. 2014. http://www3.weforum.org/docs/WEF GlobalCompetitivenessReport 2014-15.pdf

World Economic Forum. “The Global Competitiveness Report 2015-2016." Insight Report. 2015. http://www3.weforum.org/docs/gcr/2015-2016/ Global Competitiveness Report 2015-2016.pdf 
World Economic Forum. "The Global Competitiveness Report 2016-2017." Insight Report. 2016. http://www3.weforum.org/docs/GCR2016-2017/05FullReport/ TheGlobalCompetitivenessReport2016-2017_FINAL.pdf

World Economic Forum. "The Global Competitiveness Report 2018.” Insight Report. 2017. http://www3.weforum.org/docs/GCR2018/05FullReport/ TheGlobalCompetitivenessReport2018.pdf

World Economic Forum. “The Global Competitiveness Report 2019.” Insight Report. 2018. http://www3.weforum.org/docs/WEF TheGlobalCompetitivenessReport2019.pdf

XE. "XE Currency Charts: RUB to USD.” XE Currency Charts. Accessed May 21, 2020. https:// www.xe.com/currencycharts/?from $=$ RUB\&to $=U S D \& v i e w=10 Y$

Zykov, Kirill. “Putin’s Counter-Sanctions Cost Russians \$70 Per Person Every Year.” Moscow Times. October 29, 2019. https://www.themoscowtimes.com/2019/10/29/putins-countersanctions-cost-70-person-a67947 


\section{Secondary Sources}

Adewale, Aregbeshola R. "Import substitution industrialisation and economic growth - Evidence from the group of BRICS countries." Future Business Journal 3, no. 2 (2017): 138-158. https://www.sciencedirect.com/science/article/pii/S2314721017300713

Anderson, M. S. "The Great Powers and the Russian Annexation of the Crimea, 1783-4." The Slavonic and East European Review 37, no. 88 (December 1958): 17-41. https:// www.jstor.org/stable/4205010?seq=1\#metadata_info_tab_contents

Applebaum, Anne. "Russia is cultivating Germany's far right. Germans don't seem to care." The Washington Post. April 12, 2019. https://go-gale-com.proxy.library.carleton.ca/ps/i.do?

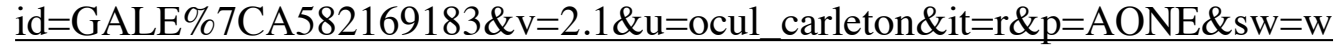

Baldwin, David. "Economic Statecraft.” In Encyclopedia Britannica. May 22, 2020. https:// www.britannica.com/topic/economic-statecraft

Baldwin, David Allen. Economic Statecraft. Princeton University Press. 1985. https:// books.google.ca/books/about/Economic_Statecraft.html?id=1tgP1Zi7kwwC

Baldwin, David Allen. "The Power of Positive Sanctions.” World Politics 24, no. 1 (1971): 19-38. https://www.princeton.edu/ dbaldwin/selected\%20articles/ Baldwin\%20(1971)\%20The\%20Power\%20of\%20Positive\%20Sanctions.pdf

Banse, Martin. Ivan Duric, Linde Gotz, and Verena Laquai. "From the Russian food import ban to free trade from Lisbon to Vladivostok - will farmers benefit?" Journal of International Studies 12, no. 4 (2019): 20-31. https://www.jois.eu/files/2_729_Banse\%20et\%20al.pdf

Benn, David Wedgwood. "Review: The Crimean War and its lessons for today." International Affairs 88, no. 2 (2012): 387-391. https://www.jstor.org/stable/41428613? seq $=1 \#$ metadata info tab contents

Berg, Ryan C., and Andres Martinez-Fernandez. "Venezuela Is Armed to the Hilt." Foreign Policy. May 2, 2019. https://foreignpolicy.com/2019/05/02/venezuela-is-armed-to-the-hilt/

Berridge, G. R. Diplomacy: Theory and Practice: Fourth Edition. 2010. https://doi.org/ $10.1057 / 9781137445520$.

Bolks, Sean M., and Dina Al-Sowayel. "How Long Do Economic Sanctions Last? Examining the Sanctioning Process through Duration.” Political Research Quarterly 53, no. 2 (2000). https://journals.sagepub.com/doi/10.1177/106591290005300202

Bugajski, Janusz. "Moscow's Anti-Western Social Offensive.” Center For European Policy Analysis. June 13, 2018. https://www.cepa.org/moscows-anti-western-social-offense

Chappelow, Jim. "Gross National Product (GNP).” Investopedia: Macroeconomics. March 20, 2020. https://www.investopedia.com/terms/g/gnp.asp 
Chatzky, Andrew. "Have Sanctions on Russia Changed Putin's Calculus?” Council on Foreign Relations: In brief. May 2, 2019. https://www.cfr.org/in-brief/have-sanctions-russiachanged-putins-calculus

Cheptea, Angela, and Carl Gaigne. "Russian food embargo and the lost trade." Working Paper SMART - LERECO no. 18-05 (September 2018): 684-718. https://academic .oup.com/erae/ $\underline{\operatorname{article}-a b s t r a c t / 47 / 2 / 684 / 5567118}$

Connable, Ben, Stephanie Young, Stephanie Pezard, Andrew Radin, Raphael S. Cohen, Katya Migacheva, and James Sladde. "Russia's Hostile Measures: Combating Russian Gray Zone Aggression Against NATO in the Contact, Blunt, and Surge Layers of Competition." RAND Corporation. 2020. https://www.rand.org/content/dam/rand/pubs/research reports/ RR2500/RR2539/RAND RR2539.pdf

Ćwiek-Karpowicz, Jarosław, and Stanislav Secrieru. Sanctions and Russia. The Polish Institute of International Affairs. 2015. https://www.files.ethz.ch/isn/187505/

Sanctions\%20and\%20Russia.pdf

Daase, Christopher, and Oliver Meier. Arms control in the 21 st century between coercion and cooperation. Routledge Global Security Studies. 2013. https://oculcrl.primo.exlibrisgroup.com/discovery/fulldisplay? docid=alma991022626571105153\&context=L\&vid=01OCUL_CRL:CRL_DEFAULT\&la $\underline{\text { ng}=e n \& s e a r c h ~ s c o p e}=$ MyInst and CI\&adaptor $=$ Local\%20Search\%20Engine\&tab=Every thing\&query=any,contains, sanctions $\% 20$ prevent $\% 20$ nuclear\&offset $=0$

Davidson, Jason, and George Shambaugh. "Chapter 3: Who's Afraid of Economic Incentives? The Efficacy-Externality Tradeoff." Sanctions as Economic Statecraft. Palgrave Macmillan. 2000. https://link.springer.com/content/pdf/10.1057/9780230596979 3.pdf

Depersio, Greg. "How does the price of oil affect Russia's economy?" Investopedia. April 11, 2019. https://www.investopedia.com/ask/answers/030315/how-does-price-oil-affectrussias-economy.asp

Di Bella, Gabriel, Oksana Dynnikova and Slavi Slavov. “The Russian State's Size and its Footprint: Have They Increased?" IMF Working Paper. International Monetary Fund. March 8, 2019. https://www.imf.org/en/Publications/WP/Issues/2019/03/09/The-RussianStates-Size-and-its-Footprint-Have-They-Increased-46662

Dorussen, Han. "Mixing Carrots with Sticks: Evaluating the Effectiveness of Positive Incentives." Journal of Peace Research 38, no. 2 (2001). https://journals.sagepub.com/doi/ pdf/10.1177/0022343301038002009

Dorussen, Han, and Jongryn Mo. "Ending Economic Sanctions: Audience Costs and RentSeeking as Commitment Strategies.” Journal of Conflict Resolution 45, no. 4 (2001). https://journals.sagepub.com/doi/10.1177/0022002701045004001 
Dorussen, Han, and Jongryn Mo. "SANCTIONS AND INCENTIVES." Globalization and Armed Conflict Workshop. European Consortium on Political Research. April 15-18, 2020. https://ecpr.eu/Filestore/PaperProposal/11440a6c-ecb2-45b8-a98b-eb32fe1ff7ec.pdf

Doxey, Margaret. International Sanctions in Contemporary Perspective. Palgrave Macmillan. 1987. https://www.palgrave.com/gp/book/9781349187508

Drezner, Daniel W. The Sanctions Paradox: Economic Statecraft and International Relations. Cambridge University Press. 1999. https://www.cambridge.org/core/books/sanctionsparadox/4542E89CDBABCBE49039C580F9A7F5F3

Drury, A. Cooper. "Sanctions as Coercive Diplomacy: The U. S. President's Decision to Initiate Economic Sanctions." Political Research Quarterly 54, no. 3 (2001). https://doi.org/ $\underline{10.2307 / 449267 .}$

Economist. "South Africa's love-affair with Russia." Economist: Middle East and Africa. March 16, 2017. https://www.economist.com/middle-east-and-africa/2017/03/16/south-africaslove-affair-with-russia

Economist. "What are the Minsk agreements?" Economist Explains. September 14, 2016. https:// www.economist.com/the-economist-explains/2016/09/13/what-are-the-minsk-agreements

Ekspertniy institute socialnych isledovaniy (EISI). “Zapadnye sankzii v otnoshenii Rossii: Charakter vozdeistviya i perspektivy razvitiya: Analiticheskiy doklad.” 2018.

Erlich, Reese. “Trump Is Driving Iran into Russia’s Arms.” Foreign Policy: Dispatch. May 29, 2019. https://foreignpolicy.com/2019/05/29/trump-is-driving-iran-into-russias-armsnuclear-deal-putin-rouhani-sanctions/

Fearon, James D. "Domestic Politics, Foreign Policy, and Theories of International Relations." Annual Review of Political Science 1 (June 1998): 289-313. https:// www.annualreviews.org/doi/pdf/10.1146/annurev.polisci.1.1.289

Frye, Timothy. "Do Economic Sanctions Cause a Rally around the Flag?" Center on Global Energy Policy. Columbia I SIPA. August, 3, 2017. https://energypolicy.columbia.edu/sites/ default/files/SanctionsandRallyAroundtheFlagTimFrye0817.pdf

Galbert, de Simon. "The Impact of the Normandy Format on the Conflict in Ukraine: Four Leaders, Three Cease-fires, and Two Summits." Center for Strategic and International Studies. October 23, 2015. https://www.csis.org/analysis/impact-normandy-formatconflict-ukraine-four-leaders-three-cease-fires-and-two-summits

Galiani, Sebastian, and Paulo Somaini. "Path-dependent import-substitution policies: the case of Argentina in the twentieth century." Latin American Economic Review 27, no. 5 (2018). https://link.springer.com/content/pdf/10.1007/s40503-017-0047-4.pdf 
Gilligan, Emma. "Smart sanctions against Russia: human rights, Magnitsky and the Ukrainian crisis." Demokratizatsiya: The Journal of Post-Soviet Democratization 24, no. 2 (2016): 257-277. https://muse.jhu.edu/article/619863/pdf

Ginat, Rami. "The Soviet Union and the Syrian Ba'th Regime: From Hesitation to Rapprochement." Middle Eastern Studies 36, no. 2 (April 2000): 150-171. https:// www.jstor.org/stable/pdf/4284075.pdf? refreqid=excelsior\%3A6d2e051f8c5ed1 ac72e982058190951a

Giumelli, Francesco. "How EU sanctions work: A new narrative.” Chaillot Papers no. 129. European Union: Institute for Security Studies. May 2013. https://www.iss.europa.eu/ sites/default/files/EUISSFiles/Chaillot 129.pdf

Gould-Davies, Nigel. "Russia's Economic Security Strategy Has Become an Internal Critique." Chatham House: Expert Comment. June 20, 2017. https://www.chathamhouse.org/expert/ comment/russia-s-economic-security-strategy-has-become-internal-critique

Gordon, Joy. “A Peaceful, Silent, Deadly Remedy: The Ethics of Economic Sanctions.” Ethics \& International Affairs 13 (1999): 123-142. https://www.cambridge.org/core/journals/ethicsand-international-affairs/article/peaceful-silent-deadly-remedy-the-ethics-of-economicsanctions/94DEA3ED067DCB5B522CE8956324B8A1

Guangcheng, Xing, and Wang Xuemei. "Russia Supports the Chinese Belt and Road Initiative." Valdai I Discussion Club: Expert Opinions. April 25, 2019. https://valdaiclub.com/a/ highlights/russia-supports-the-chinese-belt-and-road/

Hampson, Fen Osler. Master of Persuasion: Brian Mulroney's Global Legacy. Toronto: Signal. April 2018. https://doi.org/10.1177/0020702019876376.

Hofmann, Rainer. “Annexation.” In Max Planck Encyclopedias of International Law. January 2020. https://opil.ouplaw.com/view/10.1093/law:epil/9780199231690/ law-9780199231690-e1376

Holl, Jane E. et al. Preventing Deadly Conflict: Final Report. Carnegie Corporation of New York. 1997. https://www.carnegie.org/publications/preventing-deadly-conflict-final-report/

Hufbauer, Gary Clyde, Jeffrey J. Schott, Kimberley Ann Elliot, and Barbara Oegg. "Economic Sanctions Reconsidered," Peterson Institute for International Economics. 2007.

Joseph Hage Aaronson LLP. "Swiss sanctions against Russia are updated." Litigations and Sanctions. March 6, 2015. https://www.lexology.com/library/detail.aspx? $\mathrm{g}=7 \mathrm{f} 6 \mathrm{ad} 7 \mathrm{cf}-51 \mathrm{da}-4702-\mathrm{b} 9 \mathrm{a} 4-14 \mathrm{a} 1 \mathrm{f} 346 \mathrm{f} 6 \mathrm{e} 2$

Kalb, Marvin. Imperial Gamble: Putin, Ukraine, and the New Cold War. Brookings Institution Press. September 21, 2015. https://www.jstor.org/stable/10.7864/j.ctt15hvrbc 
Kapsdorferova, Zuzana, and Olga Sviridova. "Impact of sanctions on agricultural policy in European Union and Russia." International Scientific days. Conference Paper. June 2016. https://www.researchgate.net/publication/

$\underline{308127631 \text { Impact of sanctions on agricultural policy in European Union and Russi }}$

a

Katz, Mark N. “The Putin-Chavez Partnership.” Problems of Post-Communism 53, no. 4 (August 2006): 3-9. http://www.marknkatz.com/files/Putin_Chavez.pdf

Khadduri, Majid, and Hugh Kennedy. "Iraq: The UN Embargo and Oil-for-Food Program.” In Encyclopaedia Britannica. May 9, 2020. https://www.britannica.com/place/Iraq/The-UNembargo-and-oil-for-food-program

Khudoley, Konstantin K. "Russia's foreign policy amid current international tensions." Teorija in Praksa 53, no. 2 (2016): 388-408. http://dk.fdv.uni-lj.si/db/pdfs/TiP2016 2 Khudoley.pdf

Kirk, Lisbeth. "Russia divides Europe's eurosceptic parties." EUobserver: Foreign affairs. April 10, 2019. https://euobserver.com/foreign/144631

Klinova, Marina, and Elena Sidorova. "Ekonomicheskiye sanktsii i ich vliyaniye na chozyaiystvenye svyazi Rossii s Evropeiskim Souzom.” Voprosy ekonomiki 12 (2014).

Klinova, Marina, and Elena Sidorova. "Ekonomicheskiye sanktsii protiv Rossii: Razvitiye Situazii.” Problemy xprognozirovaniya 3 (2019).

Kolesnikov, Andrei, and Denis Volkov. "Pragmatic Paternalism: The Russian Public and the Private Sector." Russian Domestic Politics and Political Institutions / Russian Ideology. Carnegie Moscow Center. January 18, 2019. https://carnegie.ru/commentary/78155

Kozhanov, Nikolay. "Russia’s Relations with Iran: Dialogue without Commitments.” Policy Focus no. 120. The Washington Institute for Near East Policy. June 2012. https:// www.washingtoninstitute.org/uploads/Documents/pubs/PolicyFocus 120.pdf

Kozhanov, Nikolay. "Understanding the Revitalization of Russian-Iranian Relations." Carnegie Endowment for International Peace. Carnegie Moscow Center. 2015. https:// www.jstor.org/stable/pdf/resrep12996.pdf? $\underline{\text { refreqid=excelsior\%3Ade89b887005512c8208f2743f1e4dcdf }}$

Krekó, Péter, Marie Macaulay, Csaba Molnár, and Lóránt Győri. “Europe’s New Pro-Putin Coalition: the Parties of 'No'." Political Capital Institute. Institute of Modern Russia. August 3, 2015. https://imrussia.org/en/analysis/world/2368-europes-new-pro-putincoalition-the-parties-of-no

Lehne, Stefan. "REVIVING THE OSCE European Security and the Ukraine Crisis." Carnegie Endowment for International Peace. 2015. https://www.jstor.org/stable/pdf/ resrep12952.pdf?refreqid=excelsior\%3Abecc8c3d0af0e3efeab964cb0f3194f1 
Levinson, Alexey. "Public opinion and propaganda in Russia." European Council on Foreign Relations. July 28, 2015. https://www.ecfr.eu/article/ commentary_public_opinion_and_propaganda_in_russia3080

Lopez George A., and David Cortright. "The Key to a 'Smart' Sanctions Strategy." Die FriedensWarte 72, no. 4 (1997): 327-336. https://www.jstor.org/stable/pdf/23778409.pdf? $\underline{\text { refreqid }=\text { excelsior\%3Ab3ad2a } \% \mathrm{~b} 5 \mathrm{~d} 03 \mathrm{~b} 47 \mathrm{~d} 7 \mathrm{f} 649 \mathrm{e} 76 \mathrm{~b} 77790 \mathrm{e} 0}$

Mackinnon, Amy. "Maduro vs. Guaido: A Global Scorecard.” Infographic. February 6, 2019. https://foreignpolicy.com/2019/02/06/maduro-vs-guaido-a-global-scorecard-mapinfographic/

Marples, David R., and Frederick V. Mills. Ukraine's Euromaidan: Analyses of a Civil Revolution. ibidem Press. April 1, 2015. https://www.amazon.ca/Ukraines-EuromaidanAnalyses-Civil-Revolution/dp/3838207408

Marten, Kimberley. "Reducing Tensions Between Russia and NATO.” Council Special Report no. 79. Council on Foreign Relations. Mach 2017. https://www.cfr.org/sites/default/files/ pdf/2017/03/CSR_79_Marten_RussiaNATO.pdf

Martin, Lisa. Coercive Cooperation: Explaining Multilateral Economic Sanctions. Princeton University Press. 1992. https://press.princeton.edu/books/paperback/9780691034768/ coercive-cooperation

Masters, Jonathan. "What Are Economic Sanctions?” Council on Foreign Relations. August 12, 2019. https://www.cfr.org/backgrounder/what-are-economic-sanctions

McGillivray, Fiona, and Allan C. Stam. "Political Institutions, Coercive Diplomacy, and the Duration of Economic Sanctions." The Journal of Conflict Resolution 48, no. 2 (2004): 154-72. https://www.jstor.org/stable/3176248?seq=1\#metadata_info_tab_contents

Mearsheimer, John. "Why the Ukraine Crisis Is the West's Fault: The Liberal Delusions That Provoked Putin.” Foreign Affairs 93 (2014). https://doi.org/http://dx.doi.org/ $\underline{10.1108 / 17506200710779521 .}$

Perović, Jeronim and Benno Zogg. "Russia and China: The Potential of Their Partnership." Center for Security Studies: Analyses in Security Policy no. 250 (October 2019).

Miller, Nicholas L. "The Secret Success of Nonproliferation Sanctions.” International Organization 68, no. 4 (2014): 913-944. https://www.jstor.org/stable/pdf/43283283.pdf? casa_token=KhLRSQ_ZvI0AAAAA:004j_3Ujc26yZOfLx2WVD3wD7F_QVe39shzAp9 TO37FWCQVEjwpU8rY8FgBpklk5Cfi2Ij8d6-1v6saOIfhKsgvLMfVzH5jooEWK XSOo EPKQBS5FfiMlw

Miyagawa, Makio. Do Economic Sanctions Work? Macmillan Press. 1992. https://doi.org/ 10.1007/978-1-349-22400-5. 
Moret, Erica, Thomas Biersteker, Francesco Giumelli, Clara Portela, et al. The New Deterrent? International Sanctions Against Russia over the Ukraine Crisis: Impacts, Costs and Further Action. The Graduate Institute of Geneva and the Geneva International Sanctions Network. October 12, 2016.

Nephew, Richard. The Art of Sanctions: A View From the Field. New York: Columbia University Press. 2018.

Nic, Milan, and Andras Racz. "Point of No Return: Viktor Orbán's Divorce from the EPP." DGAP Policy Brief. May 21, 2019. https://dgap.org/en/research/publications/point-no$\underline{\text { return }}$

Nuclear Threat Initiative. "Russia's Lukewarm Support for International Sanctions against Iran: History and Motivations.” Nuclear Threat Initiative. April 15, 2020. https://www.nti.org/ analysis/articles/russias-support-sanctions-against-iran/

Nye, Joseph. Bound to Lead: The Changing Nature of American Power. New York: Basic Books. 1990.

Nye, Joseph. “Get Smart: Combining Hard and Soft Power.” Foreign Affairs. August, 2019.

Oliker, Olga, Michael J. McNerney, and Lynn E. Davis. "NATO Needs a Comprehensive Strategy for Russia.” RAND Corporation. 2015. https://www.jstor.org/stable/pdf/ resrep02433.pdf?refreqid=excelsior\%3A9d25f8aafc6bba52c4d0f258692fa90b

Oliker, Olga. "Unpacking Russia's New National Security Strategy.” Center for Strategic and International Studies. January 7, 2016. https://www.csis.org/analysis/unpacking-russiasnew-national-security-strategy

Onion, Amanda, Missy Sullivan and Matt Mullen. "Ukraine declares its independence." This day in History - January 26, 1918. November 5, 2009. https://www.history.com/this-day-inhistory/ukraine-declares-its-independence

Oxenstierna, Susanne, and Per Olsson. "The Economic Sanctions Against Russia: Impact and Prospects of Success.” FOI: Swedish Defence Research Agency: September, 2015.

Pew Research Center. "Russians Return to Religion, But Not to Church." Religion \& Public Life. February 10, 2014. https://www.pewforum.org/2014/02/10/russians-return-to-religion-butnot-to-church/

Picardo, Elvis. "10 Countries with the Biggest Forex Reserves." Investopedia: FOREX Trading Strategy and Education. March 7, 2020. https://www.investopedia.com/articles/investing/ 033115/10-countries-biggest-forex-reserves.asp

Pifer, Steven. "Five years after Crimea's illegal annexation, the issue is no closer to resolution." The Brookings Institution. March 18, 2019. https://www.brookings.edu/blog/order-from- 
chaos/2019/03/18/five-years-after-crimeas-illegal-annexation-the-issue-is-no-closer-toresolution/

Pikayev, Alexander A. "Why Russia Supported Sanctions Against Iran.” Middlebury Institute of International Studies at Monterey. James Martin Center for Nonproliferation Studies. June 23, 2010. https://www.nonproliferation .org/why-russia-supported-sanctions-against-iran/

Plakhov, Demyan. "Diplomatic Chess in the Arctic." NATO Association of Canada. June 25, 2018. http://natoassociation.ca/diplomatic-chess-in-the-arctic/

Pond, Elizabeth, and Hans Kundnani. “Germany's Real Role in the Ukraine Crisis.” Foreign Affairs 94 (2015). https://heinonline.org/HOL/Page?handle=hein.journals/ fora94\&div $=54 \& \mathrm{~g}$ sent $=1 \&$ casa token $=$ MZB-5yZ1OIcAAAAA:sIQ84W1yHkR6NQdQ A585MD_0oFYPFWu9vaMMWeMgm38G02eGnhR_XpTg9nBJzz5czjNMrLCnWkw\&c ollection=journals

Popescu, Nicu. "Do sanctions against Russia work?" European Union Institute for Security Studies no. 35 (December 2014). https://www.iss.europa.eu/sites/default/files/EUISSFiles/ Brief_35_Russia_sanctions.pdf

Popescu, Nicu. "Sanctions and Russia: Lessons from the Cold War." European Union Institute for Security Studies 10 (2015).

Portela, Clara. European Union Sanctions and Foreign Policy: When and Why do they work? Routledge Advances in European Politics, 2010. https://www.routledge.com/EuropeanUnion-Sanctions-and-Foreign-Policy-When-and-Why-do-they-Work/Portela/p/book/ $\underline{9780415502740}$

Rahbek-Clemmensen, Jon. "Nye militære spændinger i Nordatlanten og Arktis." Center for Militcere Studier. Københavns Universitet. March 2020. https://cms.polsci.ku.dk/ publikationer/nye-militaere-spaendinger-i-nordatlanten-og-arktis/ CMS Baggrundspapir 2020 1 _Nye_milit_re_sp_ndinger_i_Arktis_og_Nordatlanten.pdf

Rivera, Sharon Werning. "Understanding the sources of anti-Americanism in the Russian elite." Post-Soviet Affairs 35, no. 5-6 (2019): 376-392. https://www.tandfonline.com/doi/abs/ $\underline{10.1080 / 1060586 X .2019 .1662194 ? \text { journalCode }=\mathrm{rpsa} 20}$

Rogers Elizabeth S. "Using Economic Sanctions to Prevent Deadly Conflict." Belfer Center for Science and International Affairs, Harvard Kennedy School. Prepared for the Carnegie Commission on Prevent Deadly Conflict (May 1996). https://www.belfercenter.org/ publication/using-economic-sanctions-prevent-deadly-conflict

Ronzitti, Natalino, et al. "Coercive Diplomacy, Sanctions and International Law." Istituto Affari Internazionali, 2016. https://brill.com/view/title/32074 
Rothwell, Donald, Stuart Kaye, Afshin Akhtarkhavari, and Ruth Davis. "6.6 Cession and Annexation." International Law: Cases and Materials with Australian Perspectives. Cambridge University Press, 2014. https://trove.nla.gov.au/work/36918702? selectedversion=NBD51897139

Roy, Tirthankar. "The Origins of Import Substituting Industrialization in India." Economic History of Developing Regions 32, no. 1 (2017): 71-95. https://www.tandfonline.com/doi/ full/10.1080/20780389.2017.1292460

Salkind, Neil J. “Triangulation.” In Encyclopedia of Research Design, 2010. https:// methods.sagepub.com/reference/encyc-of-research-design/n469.xml

Sanghi, Apurva and Shahid Yusuf. "Russia's Uphill Struggle with Innovation.” World Bank. September 17, 2018. https://www.worldbank.org/en/news/opinion/2018/09/17/russiasuphill-struggle-with-innovation

Schmidt-Felzman, Anke. "Is the EU's failed relationship with Russia the member states' fault?" L'Europe en Formation 4, no. 374 (2014): 40-60. https://www.cairn.info/revue-l-europeen-formation-2014-4-page-40.htm\#

Schubert, Walt. "Peace defense." Forum for Social Economics 12, no. 1 (1982): 23-47. https:// www.tandfonline.com/doi/pdf/10.1007/BF02761631? casa token=rVNiFEtQ4YAAAAAA:xSNTjmS0z6tldesY7yfOLb8zUAgmjI2uPT5v2ums59rv2i8mSBqZm5aFcEK-pnz1wF0QO6HCDZrAj8

Segal, Troy. "Import Substitution Industrialization - ISI.” Investopedia. April 11, 2019. https:// www.investopedia.com/terms/i/importsubstitutionindustrialization.asp

Seton-Watson, Hugh, Andrew B. Wachtel, et al. "Religion.” Russia. In Encyclopedia Britannica. May 16, 2020. https://www.britannica.com/place/Russia/Religion

Shagina, Maria. "Japan's Dilemma with Sanctions Policy Towards Russia: A Delicate Balancing Act." Institute for Security \& Development Policy. November 2018. https:// www.researchgate.net/publication/ 329058965_Japan's_Dilemma_with_Sanctions_Policy_Towards_Russia_A_Delicate_Bala ncing Act

Shuette, Leonard. "Should the EU make foreign policy decisions by majority voting?" Center for European Reform. May 2019. https://www.cer.eu/sites/default/files/ pbrief qmv 15.5.19 1.pdf

Smith, John, and Kieran Beer. Sanctions with John Smith. Financial Crime Matters (Podcast), April 15, 2019.

Snegovaya, Maria. “Anti-Western Sentiment as the Basis for Russian Unity.” Carnegie Moscow Center. November 4, 2014. https://carnegie.ru/commentary/57115 
Snyder, Timothy. "The Real Reason Russia is 'Helping' Syria.” TIME. September 30, 2015. https://time.com/4054941/putin-russia-syria/

Speier, Richard H., Brian G. Chow, and S. Rae Starr. Nonproliferation Sanctions. RAND, 2001. https://www.questia.com/library/105898374/nonproliferation-sanctions

Standish, Reid, and Amy Mackinnon. "Putin Moves to Heighten Russia's Role After Suleimani Killing.” Foreign Policy: Report. January 8, 2020. https://foreignpolicy.com/2020/01/08/ putin-suleimani-russia-iran/

Stockholm International Peace Research Institute. "Chapter 6: World nuclear forces.” SIPRI Yearbook 2019. Oxford University Press. 2019. https://sipri.org/yearbook/2019/06/

Symons, Emma-Kate. "The big winner in the French election will be Vladimir Putin." Quartz. April 19, 2017. https://qz.com/961177/french-election-2017-marine-lepen-and-emmanuelmacron-lead-but-the-big-winner-in-the-french-election-will-be-vladimir-putin/

Taylor, Margaret L. "Combating disinformation and foreign interference in democracies: Lessons from Europe." Cybersecurity and Election Interference. The Brookings Institution. July 31, 2019. https://www.brookings.edu/blog/techtank/2019/07/31/combatingdisinformation-and-foreign-interference-in-democracies-lessons-from-europe/

Tyll, Ladislav, Karel Pernica and Markéta Arltová. "The impact of economic sanctions on Russian economy and the RUB/USD exchange rate." Journal of International Studies 11, no. 1 (2018): 21-33. https://www.jois.eu/files/2_481_Tyll\%20et\%20al.pdf

Twigg, Judy. "Russia Is Winning the Sanctions Game.” The National Interest. March 14, 2019. https://nationalinterest.org/blog/skeptics/russia-winning-sanctions-game-47517

Ulgen, Sinan. "It's Not Too Late to Stop Turkey From Realigning With Russia." Foreign Policy. April 11, 2019. https://foreignpolicy.com/2019/04/11/its-not-too-late-to-stop-turkey-fromrealigning-with-russia-s400-patriot-missile-putin-erdogan-trump/

Ukraine Crisis Media Center. "Image of Great Britain on Russian TV." Ukraine: Ukraine Crisis Media Center. April 10, 2018. https://www.youtube.com/watch?v=YeODPmBb3XY

Utrikesmagasinet. "The Russia-Iran Relationship in a Sanctions Era.” Ultrikespolitiska institutets nattidning. November 2019. https://www.ui.se/utrikesmagasinet/analyser/2019/november/ the-russia-iran-relationship-in-a-sanction-era/

Valery, Jorge Luis Perez, and Sean Rameswaram. "Do sanctions work?” Today, Explained. VOX (Podcast), August 19, 2019.

Walker, Christopher. “What Is 'Sharp Power'?” Journal of Democracy 29, no. 3 (2018). https:// muse.jhu.edu/article/698914\#f5-text 
Wang, Wan. "Impact of Western Sanctions on Russia in the Ukraine Crisis." Journal of Politics and Law 8, no. 2 (2015). https://heinonline.org/HOL/Page?handle=hein.journals/ jpola8\&id=166\&collection=journals\&index $=$

Warsaw Institute. "NATO-Russia Relations: The Return of the Enemy.” Special Report. April 4, 2019. https://warsawinstitute.org/wp-content/uploads/2019/04/Nato-Russia-RelationsThe-Return-of-The-Enemy-Warsaw-Institute-Special-Report.pdf

Weiss, Andrew S., and Eugene Rumer. "Nuclear Enrichment: Russia’s Ill-Fated Influence Campaign in South Africa." The Return of Global Russia. Carnegie Endowment for International Peace. December 2019. https://carnegieendowment.org/files/ Weiss Rumer SouthAfrica v2.pdf

Wezeman, Pieter D., Aude Fleurant, Alexandra Kuimova, Diego Lopes Da Silva, Nan Tian and Siemon t. Wezeman. “Trends in International Arms Transfers, 2019.” Stockholm International Peace Research Institute: Fact Sheet. March 2020. https://www.sipri.org/ sites/default/files/2020-03/fs_2003_at_2019.pdf

Wright, Robin. "Russia and Iran Deepen Ties to Challenge Trump and the United States." The New Yorker. March 2, 2018. https://www.newyorker.com/news/news-desk/russia-and-irandeepen-ties-to-challenge-trump-and-the-united-states 


\section{Appendix A}

Table 1.1: List of Sender States against Russia

\begin{tabular}{|c|c|}
\hline Sender States & Date sanctions implemented against Russia \\
\hline United States of America (US) & March 6, 2014 \\
\hline European Union (EU) & March 17, 2014 \\
\hline Canada & March 17, 2014 \\
\hline Japan & March 18, 2014 \\
\hline Norway & March 18, 2014 \\
\hline Australia & March 19, 2014 \\
\hline Moldova & March 20, 2014 \\
\hline New Zealand & March 23, 2014 \\
\hline Switzerland & April 2, 2014 \\
\hline Albania & April 11, 2014 \\
\hline Iceland & April 11, 2014 \\
\hline Montenegro & April 11, 2014 \\
\hline Ukraine & April 11, 2014 \\
\hline $\begin{array}{l}\text { United Kingdom } \\
\text { (has been part of the EU's sanctions policy until its } \\
\text { exit; currently continuing the sanctions policy) }\end{array}$ & January 31,2020 \\
\hline
\end{tabular}


Table 1.2: Minsk II agreement (13 points translated and summarized by the European Parliamentary Research Service)

\begin{tabular}{|c|c|c|}
\hline $\begin{array}{l}\text { Point } \\
\text { Number }\end{array}$ & Point Description & $\begin{array}{c}\text { Status } \\
\text { (as per the EU's March } 2018 \\
\text { Evaluation) }\end{array}$ \\
\hline 1 & Immediate, full bilateral ceasefire & Not Implemented \\
\hline 2 & $\begin{array}{l}\text { Withdrawal of all heavy weapons by both sides, establishment of } \\
\text { a security zone Partially implemented }\end{array}$ & Partially Implemented \\
\hline 3 & Monitoring of ceasefire by the OSCE & Partially Implemented \\
\hline 4 & $\begin{array}{l}\text { Modalities for local elections under Ukrainian law on special } \\
\text { status of the Donbas }\end{array}$ & Partially Implemented \\
\hline 5 & Pardon and amnesty of figures involved in the conflict & Not Implemented \\
\hline 6 & $\begin{array}{c}\text { Release and exchange of all hostages and other illegally detained } \\
\text { people }\end{array}$ & Partially Implemented \\
\hline 7 & $\begin{array}{l}\text { Safe delivery of humanitarian aid to those in need, based on an } \\
\text { international mechanism }\end{array}$ & Not Implemented \\
\hline 8 & Restoration of full social and economic links with affected areas & Partially Implemented \\
\hline 9 & $\begin{array}{l}\text { Full Ukrainian control over its border with Russia throughout the } \\
\text { conflict zone }\end{array}$ & Not Implemented \\
\hline 10 & $\begin{array}{c}\text { Withdrawal of foreign armed groups, weapons and mercenaries } \\
\text { from Ukrainian territory }\end{array}$ & Not Implemented \\
\hline 11 & $\begin{array}{l}\text { Constitutional reform including decentralisation, special status } \\
\text { for the separatist regions }\end{array}$ & Partially Implemented \\
\hline 12 & $\begin{array}{l}\text { Local elections in Donetsk and Luhansk regions according to } \\
\text { OSCE standards. }\end{array}$ & Not Implemented \\
\hline 13 & $\begin{array}{l}\text { Trilateral working groups between the Ukrainian government, the } \\
\text { separatists and Russia }\end{array}$ & $\begin{array}{l}\text { Yes, but with limited } \\
\text { results }\end{array}$ \\
\hline
\end{tabular}

Source: Organization for Security and Co-operation in Europe, and European Parliament. 
Table 2.1: An Evaluation of EU Member States Perspectives on Sanctions Against Russia

\begin{tabular}{|c|c|c|c|}
\hline \multirow[t]{2}{*}{ EU member state } & \multicolumn{3}{|c|}{ Viewpoint on sanctions against Russia } \\
\hline & $\begin{array}{l}\text { Pro-sanctions } \\
\text { (prefers the expansion } \\
\text { and extension of } \\
\text { sanctions) }\end{array}$ & $\begin{array}{l}\text { Divided, neutral, or } \\
\text { lacking interest }\end{array}$ & $\begin{array}{l}\text { Anti-sanctions } \\
\text { (prefers the removal of } \\
\text { sanctions as soon as } \\
\text { possible, is less keen on } \\
\text { expanding sanctions, or } \\
\text { promotes better relations } \\
\text { with Russia rather than } \\
\text { sanctions) }\end{array}$ \\
\hline Austria & & & $X$ \\
\hline Belgium & & $\mathrm{X}$ & \\
\hline Bulgaria & & & $\mathrm{X}$ \\
\hline Croatia & & $\mathrm{X}$ & \\
\hline Cyprus & & & $\mathrm{X}$ \\
\hline Czech Republic & $\mathrm{X}$ & & \\
\hline Denmark & $\mathrm{X}$ & & \\
\hline Estonia & $\mathrm{X}$ & & \\
\hline Finland & & $X$ & \\
\hline France & & $\mathrm{X}$ & \\
\hline Germany & & $\mathrm{X}$ & \\
\hline Greece & & & $\mathrm{X}$ \\
\hline Hungary & & & $\mathrm{X}$ \\
\hline Ireland & & & $\mathrm{X}$ \\
\hline Italy & & & $X$ \\
\hline Latvia & $\mathrm{X}$ & & \\
\hline Lithuania & $\mathrm{X}$ & & \\
\hline Luxembourg & & & $X$ \\
\hline Malta & & $\mathrm{X}$ & \\
\hline
\end{tabular}




\begin{tabular}{|c|c|c|c|}
\hline Netherlands & $\mathrm{X}$ & & \\
\hline Poland & $\mathrm{X}$ & & \\
\hline Portugal & & $\mathrm{X}$ & \\
\hline Romania & & $\mathrm{X}$ & $\mathrm{X}$ \\
\hline Slovakia & & & $\mathrm{X}$ \\
\hline Slovenia & & $\mathrm{X}$ & \\
\hline Spain & & & \\
\hline Sweden & $\mathrm{X}$ & & \\
\hline
\end{tabular}

Sources: Kremlin Watch and European Values Center for Security Policy. 
Table 3.1: Applying Miyagawa's and Additional Conditions to Russia's Vulnerability

\begin{tabular}{|c|c|c|c|c|}
\hline & & $\begin{array}{l}\text { Vulnerability does } \\
\text { not exist or Russia } \\
\text { has the capacity }\end{array}$ & $\begin{array}{c}\text { Vulnerability } \\
\text { exists, but it has } \\
\text { not been used by } \\
\text { the EU }\end{array}$ & $\begin{array}{c}\text { Vulnerability } \\
\text { utilized or Russia } \\
\text { does not have the } \\
\text { capacity }\end{array}$ \\
\hline \multirow{7}{*}{$\begin{array}{l}\text { Miyagawa's } \\
\text { conditions }\end{array}$} & Self-sufficiency & $x$ & & \\
\hline & $\begin{array}{l}\text { Large economy by } \\
\text { GNI }\end{array}$ & $x$ & & \\
\hline & Trade dependency & & $x$ & \\
\hline & $\begin{array}{l}\text { Securing } \\
\text { alternative foreign } \\
\text { sources of supply }\end{array}$ & $x$ & & \\
\hline & $\begin{array}{l}\text { Large foreign } \\
\text { reserves }\end{array}$ & $x$ & & \\
\hline & $\begin{array}{l}\text { Lack of monitoring } \\
\text { measures }\end{array}$ & & $\mathrm{x}$ & \\
\hline & $\begin{array}{l}\text { State-trading } \\
\text { country }\end{array}$ & $x$ & & \\
\hline \multirow{3}{*}{$\begin{array}{l}\text { Additional } \\
\text { conditions }\end{array}$} & $\begin{array}{l}\text { Diplomatic } \\
\text { Influence }\end{array}$ & $x$ & & \\
\hline & $\begin{array}{c}\text { Nuclear and } \\
\text { military capacity }\end{array}$ & $x$ & & \\
\hline & $\begin{array}{l}\text { Lack of } \\
\text { democracy and } \\
\text { substantial } \\
\text { domestic } \\
\text { government } \\
\text { influence }\end{array}$ & $x$ & & \\
\hline
\end{tabular}




\section{Appendix B}

Figure 3.1: Russia's GDP compared to Global Oil Prices (2008-2018)

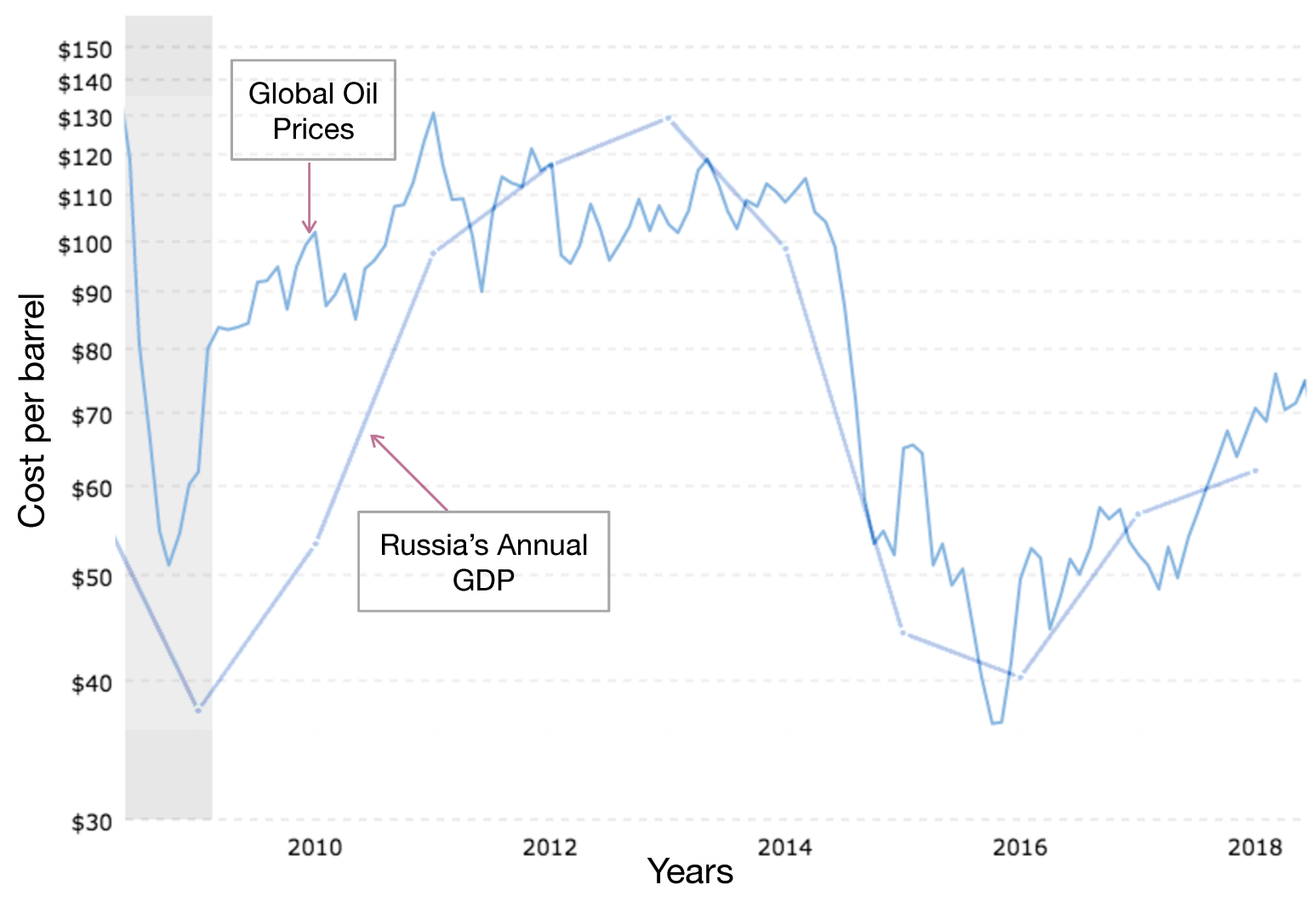

Source: World Bank and Macrotrends

Figure 3.2: Russia's Total Trade - in billions USD (1996-2019)

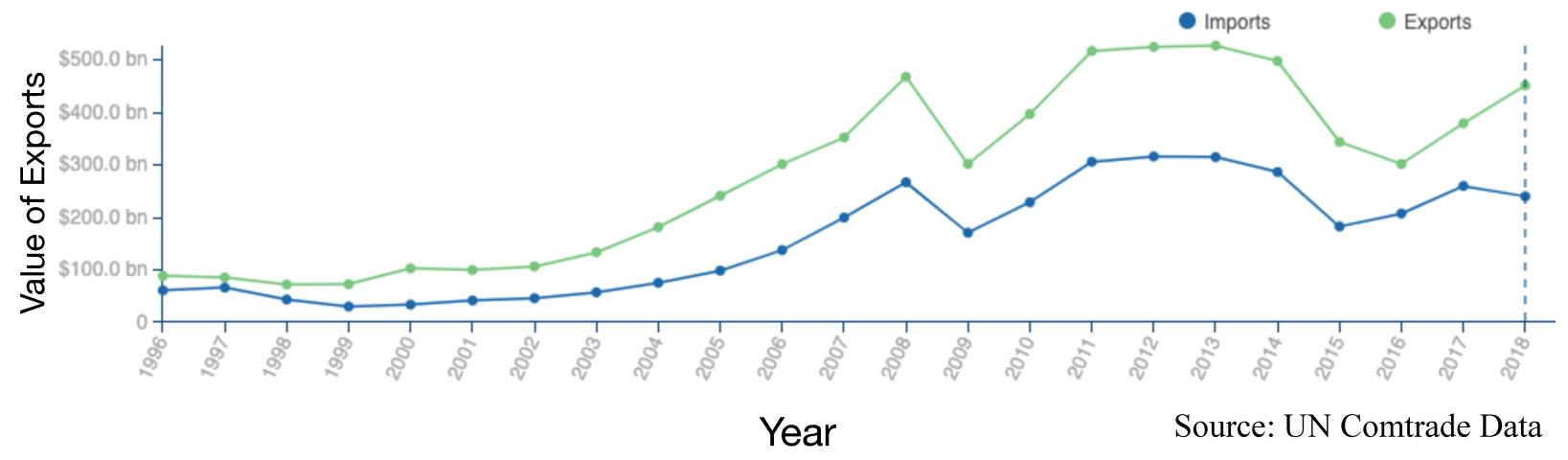


Figure 3.3: Real GDP growth - in annual \% change (1980-2020)

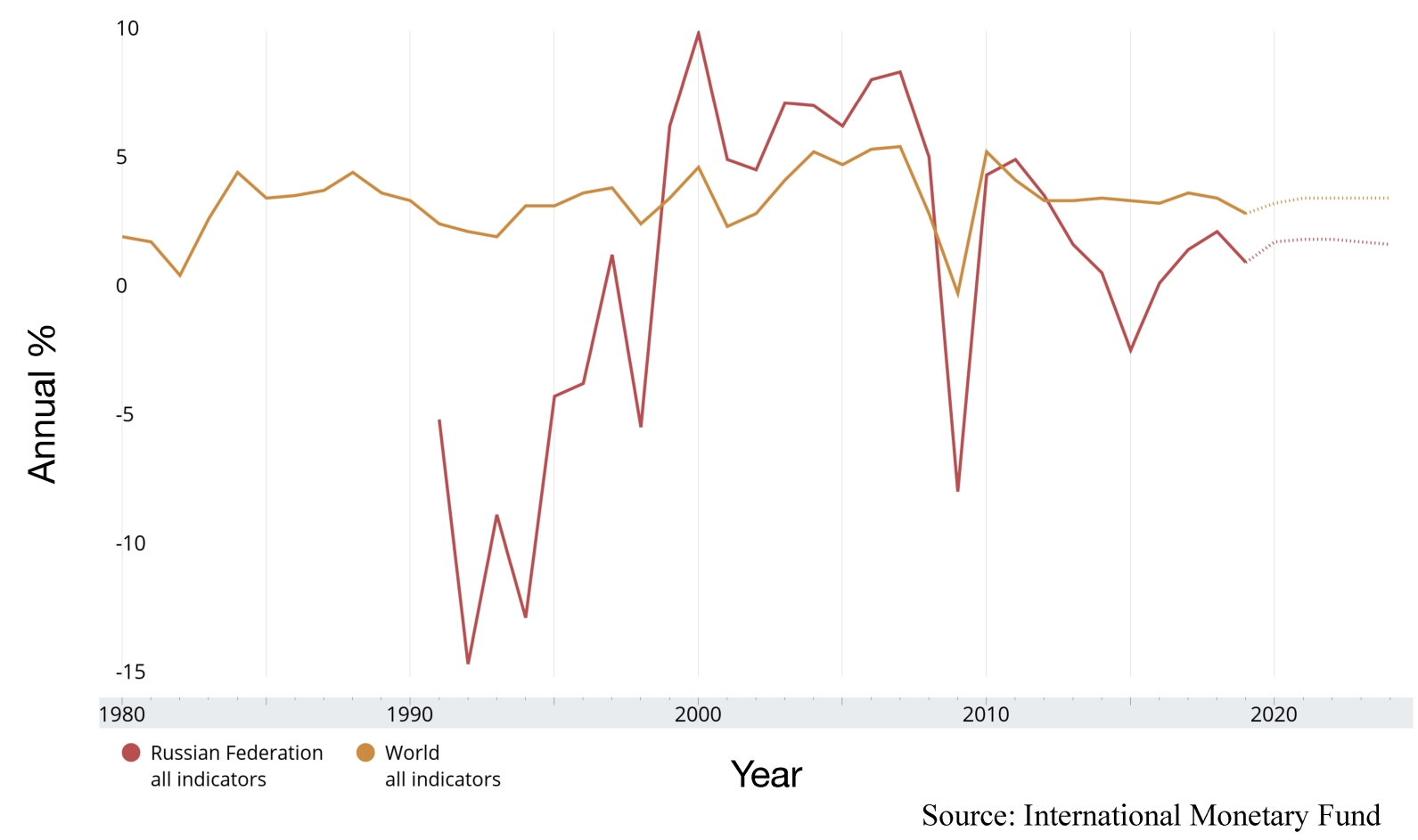

Figure 3.4: Russia Net Foreign Direct Investment - net in billions of USD (2008-2018)

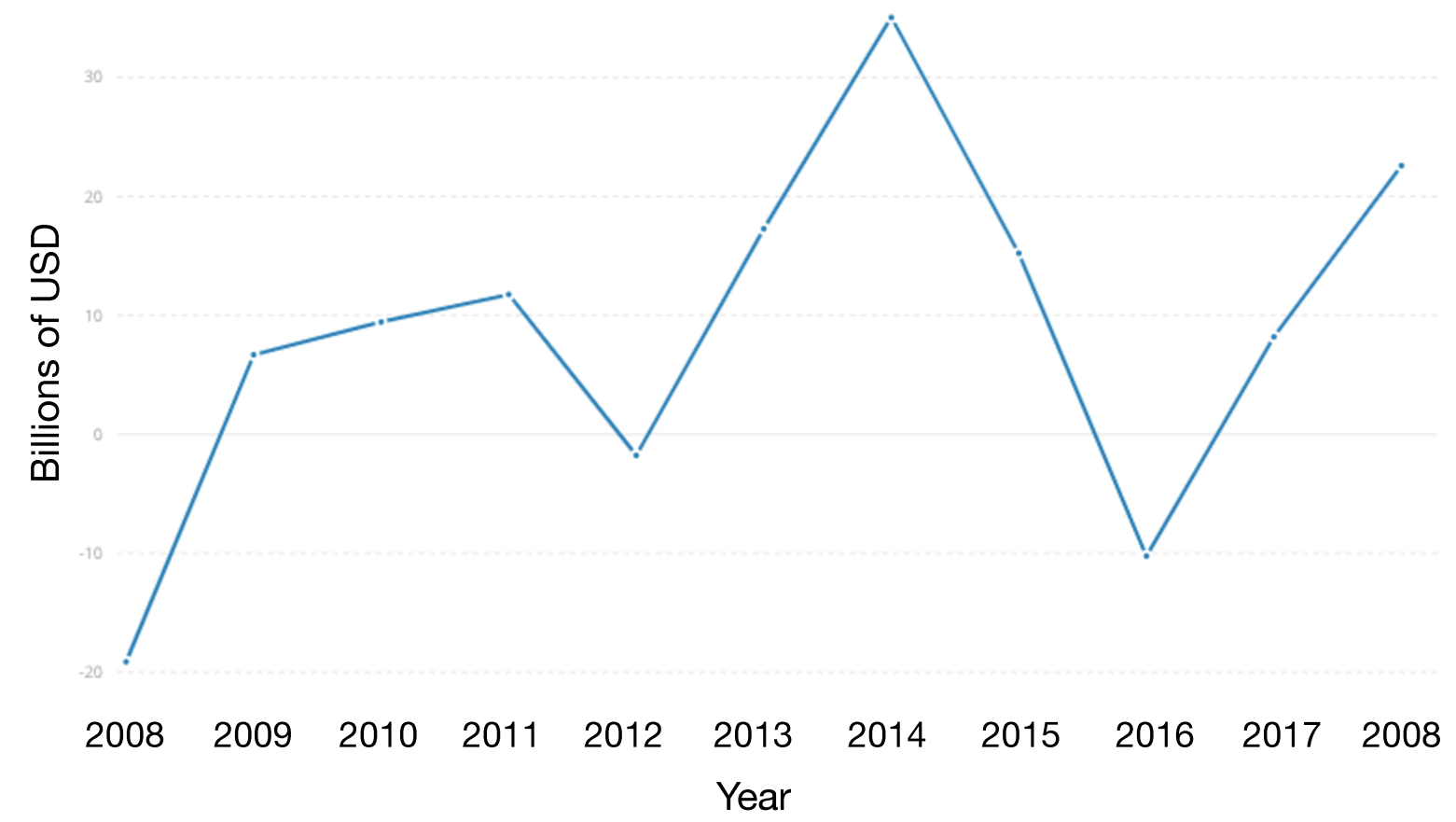

Source: World Bank 
Figure 3.5: Russian Inflation, Consumer Prices - annual \% (2001-2019)

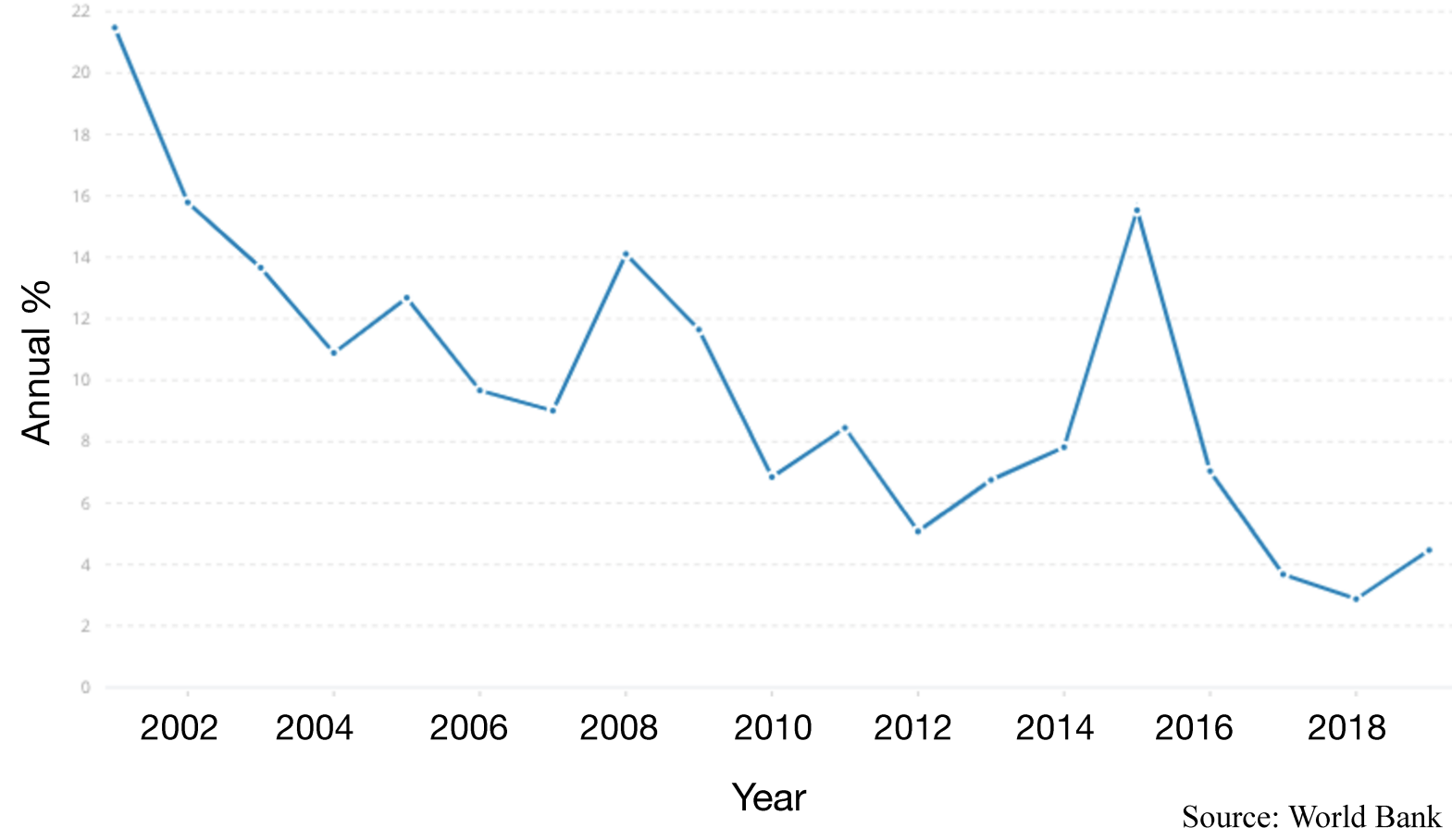

Figure 3.6: GNI of Russia and the G7 (not including US) - in trillion USD (2006-2018)

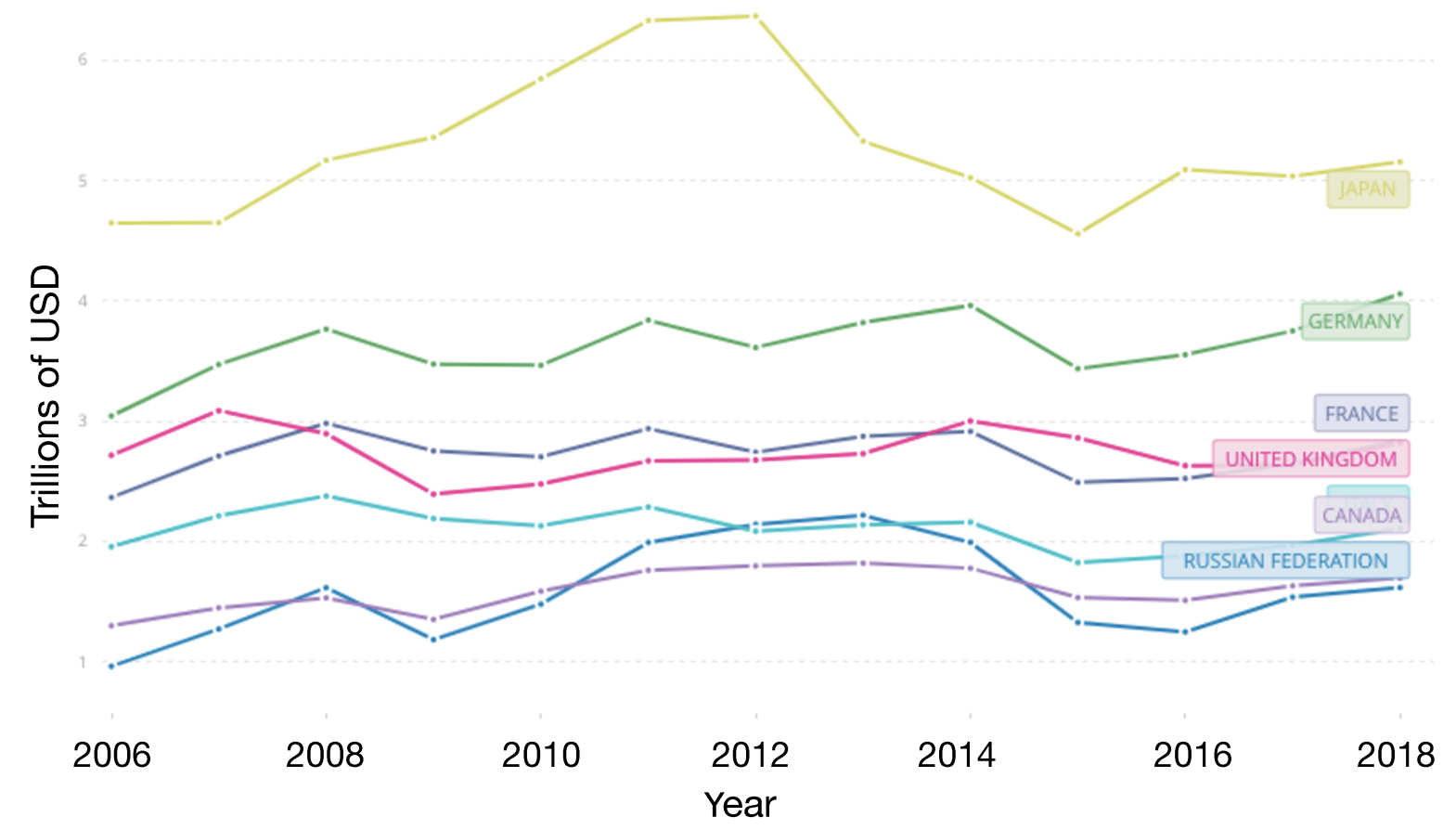

Source: World Bank 
Figure 3.7: GNI of Russia, United States, European Union - in trillion USD (2006-2018)

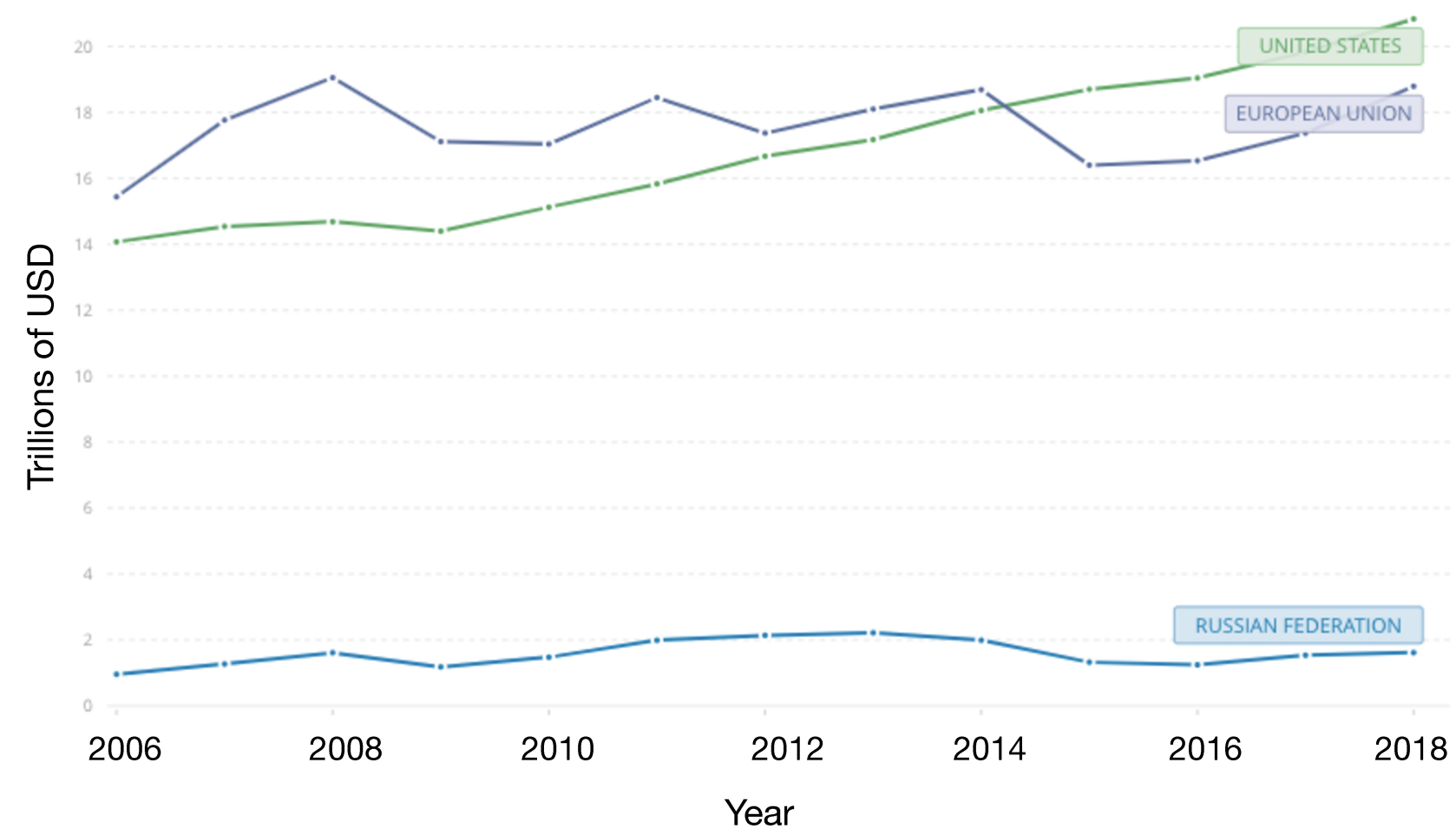

Source: World Bank 
Figure 3.8: Map of Vulnerable Shipping Routes

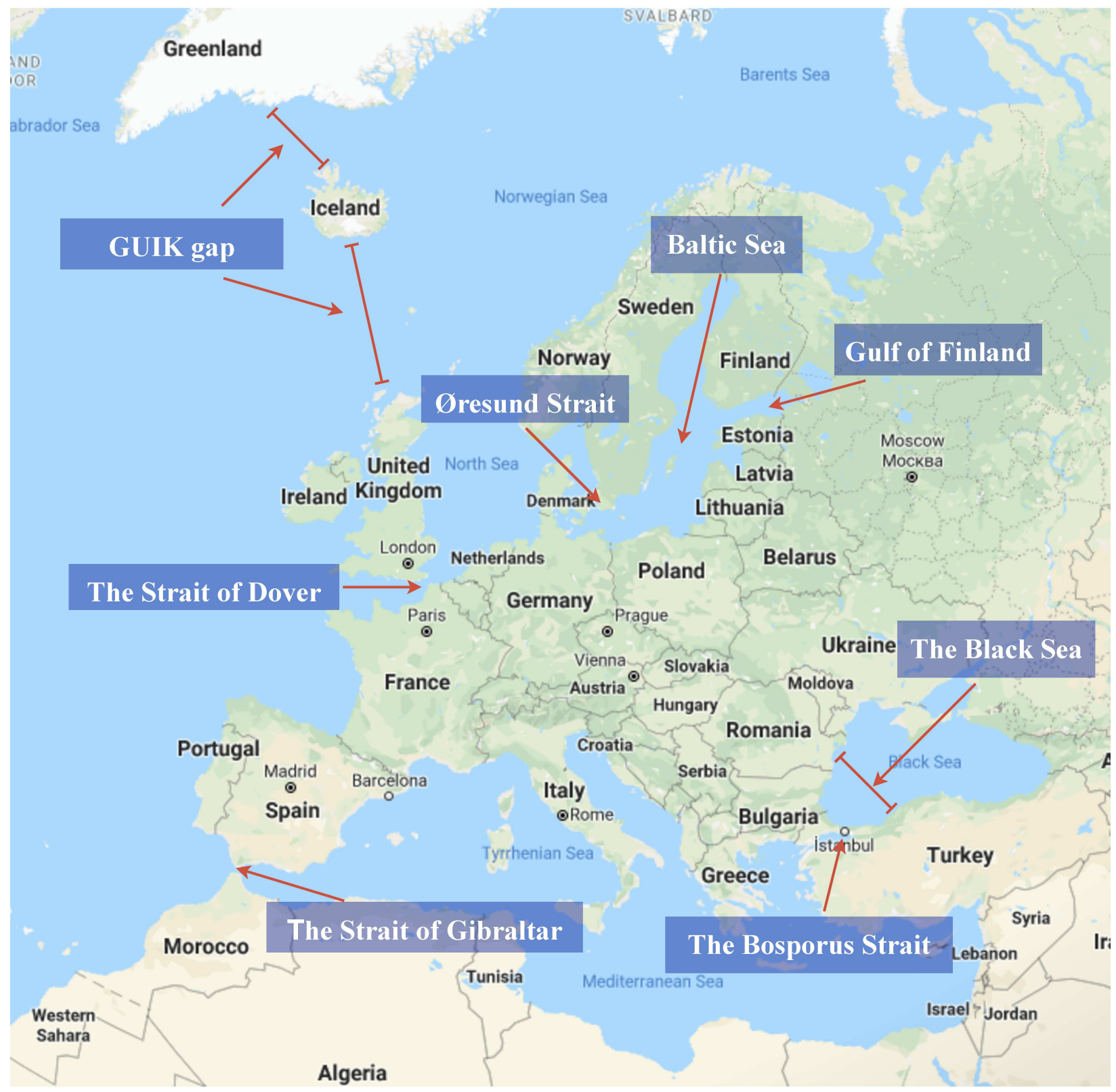

Source: Google Maps 


\section{Appendix C}

The following sections include economic, diplomatic, and internal options for EU's consideration based on this thesis research. It is a preliminary analysis of a few options that EU has in dealing with this sanctions case. The policy options are based on this thesis' findings. This section is followed by Appendix D, which lists companies and individuals not sanctioned by the EU. ${ }^{8}$

\section{Economic Options for the EU}

This section will outline several economic options that the EU should consider in this case including: i) the expansion of sanctions to major sectors and individuals not currently listed, ii) utilizing secondary sanctions, similar to the US, and iii) shifting the EU strategy. The EU also has other economic options such as maintaining current sanctions, removing them, or to slowly expand them. However, with lack of influence over Russian policy thus far, this section will attempt to provide more substantive options in terms of EU economic policy and further sanctions. It is important to consider that with these more substantive economic policies, Russia will respond accordingly if it follows its post-2014 sanctions strategy — including escalated tensions, economic warfare, more import or export bans, and etc.

First, the EU should consider the threat of sanctioning major Russian trade vulnerabilities. Specifically, this option considers enabling strict restrictive measures on several vulnerable Russian sectors. To start, the Russian export market greatly relies on the EU since

\footnotetext{
${ }^{8}$ Military options were not listed as they are not clearly covered under the EU foreign policy mandate and given the fact that the EU does not have a standing military.
} 
Russia exports roughly $\$ 43.5$ billion to Netherlands (2nd overall), $\$ 34.2$ billion to Germany (3rd overall), and $\$ 16$ billion to Poland and Italy each. ${ }^{9}$ Furthermore, Russia's imports rely on Germany for $\$ 25.5$ billion (2nd overall), and Italy and France for around $\$ 10$ billion each. ${ }^{10} \mathrm{EU}$ mostly exports to US, China, Switzerland, and then nearly $\$ 100$ billion to Russia. ${ }^{11}$ EU also mostly imports from China, US, and then $\$ 179.6$ billion Russia. Thus, Russia needs EU more in terms of trade since the EU is part of a higher share of Russia's trade turnover as opposed to the EU's more diversified share, but Russia's trade turnover is still crucial for EU to function economically.

The EU should consider the imposition of restrictive measures on energy trade with Russia. As mentioned previously, the energy trade is Russia's largest export and the federal budget largely depends on its energy export income. The energy sector is Russia's single largest export commodity, larger than the next 9 sectors. ${ }^{12}$ Nearly $\$ 80$ billion of Russia’s total $\$ 237.9$ billion from mineral, oil, gas exports goes to Netherlands, Germany, Poland, Italy, and Finland alone. ${ }^{13}$ Therefore, by placing restrictions on trade for instance, the EU would be able to create

\footnotetext{
${ }^{9}$ Department for International Trade (DIT) and the Department for Business, Energy and Industrial Strategy (BEIS) of the United Kingdom. "Russian Federation - Top-10 export markets for goods in 2018." Russian Federation exports of goods in 2018. Based on UN Comtrade data (2020).

${ }^{10}$ Department for International Trade (DIT) and the Department for Business, Energy and Industrial Strategy (BEIS) of the United Kingdom. "Russian Federation - Top-10 import markets for goods in 2018." Russian Federation exports of goods in 2018. Based on UN Comtrade data (2020).

${ }^{11}$ Department for International Trade (DIT) and the Department for Business, Energy and Industrial Strategy (BEIS) of the United Kingdom. "EU-28 - Top-10 export markets for goods in 2018." EU-28 exports of goods in 2018. Based on UN Comtrade data (2020).

12 Department for International Trade (DIT) and the Department for Business, Energy and Industrial Strategy (BEIS) of the United Kingdom. "Russian Federation - Top-10 exports of goods to World in 2018." Russian Federation exports of goods in 2018. Based on UN Comtrade data (2020).

13 Department for International Trade (DIT) and the Department for Business, Energy and Industrial Strategy (BEIS) of the United Kingdom. "Russian Federation - Top-10 export markets for Mineral fuels, oils, distillation products, etc in 2018." Russian Federation exports of Mineral fuels, oils, distillation products, etc in 2018. Based on UN Comtrade data (2020).
} 
devastating impact to Russia's economy and structure; sanctioning the following companies: Gazprom, Surgutneftegas, Lukoil, Rosneft, Tatneft, Northgas, Transneft, Transoil, Bashneft, Russneft, Itera, and Novatek. Additionally, the EU could sanction the executives, directors, or chairmen of these companies as well, including: Igor Sechin (CEO of Rosneft), Andrey Akimov (Chairman of the Board at Gazprombank), and Alexey Miller (CEO of Gazprom). These restrictive measures would both severely undercut Russia's federal budget — which would undermine Russia's ability to perform its policies and plans — and put immense individual pressure on a circle of key Russian government influencers.

At the same time, restrictive measures on Russian energy companies would also be detrimental to EU member states due to the EU-Russia interdependence. Russia is the largest supplier of oil, natural gas, and coal to the EU. The European Commission showed that, in 2018, Russia accounted for $40.5 \%$ of EU's total gas imports, while accounting for $27.3 \%$ of the EU's total oil — nearly tripling the second largest source from Norway. ${ }^{14}$ Ten EU member states imported between $75-100 \%$ of their total national gas imports from Russia and seven member states imported more than $50 \%$ of their total national petroleum imports from Russia, in the first semester of 2019.15 Further, the EU's energy mix is primarily dependent on petroleum (36\%), natural gas (23\%), and solid fossil fuels (15\%). ${ }^{16}$ Consequently, the EU is extensively dependent on Russia's energy, and restrictive measures on energy trade can put the EU's transport,

\footnotetext{
${ }^{14}$ Eurostat, "EU imports of energy products - recent developments," Statistics Explained, November 2019: 4.

15 Ibid, 10.

16 European Commission, “2.1 Where does our energy come from?” Eurostat, April 2020.

Demyan Plakhov
} 
households, and various services at risk. ${ }^{17}$ Additionally, since there is a diverse spectrum of dependability on Russian energy between EU member states, this may also create uneven negative effects and incite major discord between member states.

The EU should also consider placing restrictive measures on the export of nuclear reactors, boilers, and machinery, as it is Russia's most important import sector. The EU exports considerable amounts in this sector with the highest being from Germany ( $\$ 6.9$ billion), Italy (\$3.3 billion), Czech Republic ( $\$ 1.2$ billion), France ( $\$ 1.2$ billion), and Poland (\$1.1 billion). ${ }^{18}$ With regards to other sectors, the EU should consider placing restrictions on any investment or trade with respect to Russia's third largest import sector: vehicles (other than railway). Germany exports more than $\$ 3.8$ billion to Russia in this category, placing second overall by itself, with Slovakia (\$1.2 billion), UK (\$794 million), Czech Republic (\$743 million), and Poland (\$535 million) also in Russia's top ten in this sector. ${ }^{19}$ There are a variety of options besides complete embargoes of vehicles to Russia, however, the recently opened Mercedes-Benz factory in the industrial estate of Esipovo near Moscow, for instance, does not suit well in the framework of the EU sanctions policy towards Russia as Germany's largest automobile company directly invests 250 million euro (\$278 million) in Russia, fosters domestic employment, and creates a

\footnotetext{
${ }^{17}$ Eurostat, "Energy, transport and environment statistics." European Union, 2019: 24.

18 Department for International Trade (DIT) and the Department for Business, Energy and Industrial Strategy (BEIS) of the United Kingdom. "Russian Federation - Top-10 import markets for Nuclear reactors, boilers, machinery, etc in 2018." Russian Federation exports of Nuclear reactors, boilers, machinery, etc in 2018. Based on UN Comtrade data (2020).

${ }^{19}$ Department for International Trade (DIT) and the Department for Business, Energy and Industrial Strategy (BEIS) of the United Kingdom. "Russian Federation - Top-10 import markets for Vehicles other than railway, tramway in 2018." Russian Federation exports of Vehicles other than railway, tramway in 2018. Based on UN Comtrade data (2020).
} 
propaganda opportunity for Russian state-owned media. ${ }^{20}$ Accordingly, the EU might want to consider a step towards restricting some vehicle products and investments to Russia, as Russia is greatly reliant on European automakers. This could also be done by shifting exports and investments elsewhere. All of these options and sectors, however, could lead to uneven negative effects and incite major discord as mentioned previously. Therefore, a combination of these options can be used rather than imposing complete embargoes and boycotts on all of the abovementioned sectors.

In addition to these sectors and companies, the EU should also consider the following significant Russian companies for restrictive measures: Alrosa (state-owned diamond mining company), Magnitogorsk Iron and Steel Works, Mechel (producer of specialty steels and alloys), Severstal (steel and steel-related mining company), Sistema (a major private investor in Russia's economic development), Nornickel (the leading Russian nickel and palladium mining company), Novolipetsk (a major steel company), RUSAL (the world's second largest aluminium company), Uralkali (potash fertilizer producer and exporter), and SIBUR (a major petrochemicals company engaged in energy, automotive, and construction sectors). ${ }^{21}$ The EU should consider sanctioning individuals close to Russian decision-making or that maintain major influence in the Kremlin such as Anatoly Chubais (Head of Rusnano), Boris Rotenburg (co-owner of the SGM group), Alisher Usmanov (a major Russian business magnate), Vagit Alekperov (CEO of Novatek),

20 Russia Insight, "WHAT SANCTIONS!? Putin Signs First Mercedes-Benz Off The Production Line in New Russian Plant," Russia: Rossiya 1, Youtube, April 5, 2019;

DAMLER, "Opening of Mercedes-Benz Cars passenger car plant in Russia," Company: Locations, 2020.

${ }^{21}$ ALROSA, "Strategia, Struktura, Istoriya," O nas, 2020;

Magnitogorskiy metallurgicheskiy kombinat. "O kampanii." Glavnaya. 2020;

Severstal, "O kompanii," Severstal v tsifrakh, 2020;

Sistema, "O korporatsii," Glavnaya, 2020;

Nornickel, "Novosti," O Kompanii, 2020. 
Mikhail Fridman (co-founded Alfa-Group), and Vladimir Potanin (a major Russian business magnate). ${ }^{22}$ Further, if the EU sanctions are targeting Russian individuals who are responsible for Russia's foreign policy in the annexation of Crimea and destabilization of Ukraine, then the list should also include key Russian political decision-makers that were spearheading this foreign policy such as Vladimir Putin (President), Sergei Lavrov (Minister of Foreign Affairs), Sergey Shoygu (Minister of Defence), Vladislav Surkov (Presidential adviser), and Yevgeny Prigozhin ("Putin's chef" linked to the Wagner Group).

Secondly, the EU should consider imposing secondary sanctions similar to what the US' attempted with its legislation called Countering America's Adversaries Through Sanctions Act (CAATSA) of 2017.23 Through this legislation, the US placed secondary states and companies under pressure to prevent them from pursuing ties with their "adversaries" North Korea, Iran, and Russia. However, this has also caused a major rift between the transatlantic alliance and the unity of sender states as the US' legislation punishes EU countries and companies for their ties with Russia as well. ${ }^{24}$ As such the EU should consider in crafting a targeted secondary sanctions list, which will avoid its allies and partners, and attempt to persuade at least some secondary states and companies from entering into additional agreements with Russia. This could also be

\footnotetext{
22 Emma Burrows, "Vladimir Putin's inner circle: Who's who, and how are they connected?" CNN, March 28, 2017; Refer to Tables 1 and 2 for the complete list of individuals and companies that are not currently sanctioned.

23 One hundred fifteenth Congress of the United States of America, "Countering America's Adversaries Through Sanctions Act,” Authenticated U.S. Government Information GPO, January 3, 2017.

${ }^{24}$ Financial Times, "Berlin hits back at US move to tighten sanctions on Russia,” Financial Times, June 15, 2017; Auswartiges Amt, "Außenminister Gabriel und der österreichische Bundeskanzler Kern zu den Russland-Sanktionen durch den US-Senat," Pressemitteilung, June 15, 2017;

Clark Mindock, "Europe 'stands ready to act' if US sanctions on Russia affect its oil and gas supplies," Independent, July 26, 2017; Ingrid Melander and Brian Love, "France says U.S. sanctions on Iran, Russia look illegal," Reuters: Politics, July 26, 2017.
} 
done by providing political and economic incentives to secondary states and companies to draw them to the EU rather than Russia. Since Russia is able to receive critical support from secondary states, it is ever more critical for the EU to prevent these loopholes to create a more effective strategy.

In this case, the EU would need to target secondary states, those who are cooperating or engaging with Russia, and identify certain vulnerabilities of those secondary states — while evaluating its own potential costs. After this evaluation, the EU has the option of communicating with its sender state allies - including Canada, US, Japan, Australia — to identify the possibilities of approaching secondary sanctions together. This will prevent the discord created by the US' CAATSA, and will create a holistic approach to Russia. Then, alone or with its allies, the EU may threaten a select group of secondary states and companies. As seen in the case of Iran, secondary sanctions can be largely effective, especially when combined with the targeting of its main value of exports: oil. Likewise, the EU should consider applying secondary sanctions to the oil and gas sector, by identifying both major countries and entities that would have major consequences for Russian export of oil and gas. Another approach could be to put restrictive measures on secondary companies or countries attempting to purchase Russian weapons, such as India, Turkey, Egypt, and others.

Thirdly, these aforementioned components should be outlined by the EU's shift in economic strategy. The EU should consider enforcing a comprehensive plan to economically shift from Russia. Although some EU proposals have demonstrated this already, a holistic and exhaustive review should be made to observe the EU's recent ability to shift away from Russia. 
One of the major components of this has already been outlined by the EU - energy diversification strategy — but not necessarily met by key member states. The EU has yet to significantly diversify its energy mix and its energy trade dependence with Russia, to the point where it can halt energy resources from Russia and shift to other sources of energy. If the EU is able to diversify its energy mix, maintain an energy surplus, and have the means for selfsufficient energy sources, then it would be able to halt energy supplies from Russia more drastically. This drastic shift would be less costly to the EU, where it would be able to shift to its own energy mix and surplus, while severely damaging the Russian economy. This means that the EU should consider additional efforts to establish domestic renewable energy sources, which would be able to achieve more energy self-sufficiency, a diversified energy mix, reducing dependence on Russian energy, and achieving climate change goals.

This could be conceivable by observing the EU's recent economic strategic shift due to Russia's imposed agricultural import ban. Although the EU suffered in the short-term, it was able to recover as the European Commission introduced a series of measures for storage, compensation, and promotion of sales market diversification for EU agricultural products. ${ }^{25}$ EU's agri-food sector managed to compensate the losses of export sales to Russia by increasing exports to other alternative markets such as the China $(+33 \%)$, South Korea $(+29 \%)$, Egypt (+26\%), Hong Kong (19\%), US (+16\%), United Arab Emirates (+14\%), Saudi Arabia (+10\%), and Switzerland $(+5 \%)$. As opposed to Russia imposing damaging economic policy to the EU

\footnotetext{
25 Zuzana Kapsdorferova and Olga Sviridova, "Impact of sanctions on agricultural policy in European Union and Russia," International Scientific days, Conference Paper, June 2016.
} 
and the EU forced to adapt in the aftermath, the EU should consider preemptive economic strategies that would enable it to adapt to drastic reduction of Russian economic ties.

\section{Diplomatic Options for the EU}

The EU should also consider diplomatic options to leverage its soft power and use a larger framework of sanctions policy without necessarily utilizing hard power (i.e. economic, military, or hybrid warfare). As such, the EU should consider: i) growing multilateral support and advocating for unified intensification of sanctions across all sender states, ii) leverage international institutions as much as possible, and iii) continuously seek negotiations with Russia and seek partnership with secondary states and companies.

With respect to growing multilateral support, the EU should look to actively engage with non-sanctioning states. The EU should look to OECD (Organization for Economic Cooperation and Development) countries, with which many EU member states share membership, such as Chile, Israel, and Mexico. ${ }^{26}$ Russia's trade turnover with Chile has increased by $90.3 \%$ since 2016 - reaching an all-time high — with imports nearly doubling to $\$ 1.1$ billion. ${ }^{27}$ With respect to Chile, the EU should consider utilizing its friendly diplomatic relations and OECD partnership to negotiate an agreement that would discourage Chile's increased exports to Russia, and

26 OECD, “Where: Global Reach,” OECD Development Center, 2020.

27 Department for International Trade (DIT) and the Department for Business, Energy and Industrial Strategy (BEIS) of the United Kingdom. "Russian Federation trade in goods with Chile since 1996." Russian Federation exports of goods in 2018. Based on UN Comtrade data (2020). 
encourage increased trade with the EU.28 Russian exports to Israel dropped from 2014 to 2016, but nearly recovered to the same levels since then. ${ }^{29}$ The EU could seek a similar strategy with Israel. As it stands, Russia's eighth most important export sector to Israel is aircraft, spacecraft, and parts thereof, amounting to $\$ 24.5$ million. ${ }^{30}$ The EU should consider this particular sector since it does not currently export a significant amount to Israel, but has the capacity to do so since it is the EU's seventh largest export sector to the world accounting for $\$ 85.5$ billion. ${ }^{31}$ Finally, the EU should consider similar strategies with Mexico to discourage its growing trade turnover with Russia, leveraging the fact that Mexico's trade turnover is more than twenty times greater than its trade turnover with Russia as a negotiating factor. ${ }^{32}$

The EU should also look to Turkey and South Korea as key sanctioning strategic partners. Both nations are key trading partners for the EU. The EU's combined trade turnover with Turkey and South Korea is greater than its total trade with Russia by approximately $\$ 20$

\footnotetext{
28 Department for International Trade (DIT) and the Department for Business, Energy and Industrial Strategy (BEIS) of the United Kingdom. "EU-28 exports of goods in 2018." EU-28 trade in goods with Chile since 2000. Based on UN Comtrade data (2020).

29 Department for International Trade (DIT) and the Department for Business, Energy and Industrial Strategy (BEIS) of the United Kingdom. "Russian Federation trade in goods with Israel since 1996." Russian Federation exports of goods in 2018. Based on UN Comtrade data (2020).

${ }^{30}$ Department for International Trade (DIT) and the Department for Business, Energy and Industrial Strategy (BEIS) of the United Kingdom. "Russian Federation - Top-10 exports of goods to Israel in 2018." Russian Federation exports of goods in 2018. Based on UN Comtrade data (2020).

${ }^{31}$ Department for International Trade (DIT) and the Department for Business, Energy and Industrial Strategy (BEIS) of the United Kingdom. "EU-28 - Top-10 exports of goods to World in 2018." EU-28 exports of goods in 2018. Based on UN Comtrade data (2020).

32 Department for International Trade (DIT) and the Department for Business, Energy and Industrial Strategy (BEIS) of the United Kingdom. "EU-28 trade in goods with Mexico since 2000." EU-28 exports of goods in 2018. Based on UN Comtrade data (2020);

Department for International Trade (DIT) and the Department for Business, Energy and Industrial Strategy (BEIS) of the United Kingdom. "Russian Federation trade in goods with Mexico since 1996." Russian Federation exports of goods in 2018. Based on UN Comtrade data (2020).
} 
billion. ${ }^{33}$ Also, both Turkey and South Korea are part of the OECD and are strongly affiliated with NATO. Besides the fact that the EU is strongly affiliated with NATO through its strategic cooperation, it also shares 21 common member states that make up an overwhelming majority of the EU (78\%) and NATO (72\%). ${ }^{34}$ Additionally, Turkey is Russia's fifth most important export market amounting to $\$ 21.3$ billion, while South Korea is Russia's sixth largest export market and eighth most significant import market respectively amounting to a total $\$ 24.8$ billion — creating a particular unexploited vulnerability. ${ }^{35}$ Therefore, the EU should seek to decrease Turkey's imports of Russian goods — being a NATO ally and an OECD partner — especially with respect to Russian military goods, while seeking to decrease South Korea's imports of Russia goods as well — being a NATO and OECD partner — especially with regard to mineral fuels, oils, and distillation products. ${ }^{36}$ Similarly, the EU and its member states should consider utilizing the Mediterranean Dialogue and the EU-ASEAN partnership. ${ }^{37}$ Mediterranean Dialogue will help foster negotiations with key North African countries Algeria, Egypt, Israel, Jordan, Mauritania,

\footnotetext{
33 Department for International Trade (DIT) and the Department for Business, Energy and Industrial Strategy (BEIS) of the United Kingdom. "EU-28 - Top-10 export markets for goods in 2018." EU-28 exports of goods in 2018. Based on UN Comtrade data (2020);

Department for International Trade (DIT) and the Department for Business, Energy and Industrial Strategy (BEIS) of the United Kingdom. "EU-28 - Top-10 import markets for goods in 2018." EU-28 exports of goods in 2018. Based on UN Comtrade data (2020).

${ }^{34}$ North Atlantic Treaty Organization, "Relations with the European Union," Topics, March 23, 2020; Not counting the United Kingdom. For the EU, there are 21 NATO aligned countries out of the total EU 27. For NATO, there are $21 \mathrm{EU}$ member states out of the total 29 NATO members.

35 Department for International Trade (DIT) and the Department for Business, Energy and Industrial Strategy (BEIS) of the United Kingdom. "Russian Federation - Top-10 export markets for goods in 2018." Russian Federation exports of goods in 2018. Based on UN Comtrade data (2020).

36 Department for International Trade (DIT) and the Department for Business, Energy and Industrial Strategy (BEIS) of the United Kingdom. "Russian Federation trade in goods with Turkey since 1996." Russian Federation exports of goods in 2018. Based on UN Comtrade data (2020);

Department for International Trade (DIT) and the Department for Business, Energy and Industrial Strategy (BEIS) of the United Kingdom. "Russian Federation trade in goods with Republic of Korea since 1996." Russian Federation exports of goods in 2018. Based on UN Comtrade data (2020).
}

${ }^{37}$ North Atlantic Treaty Organization, “NATO Mediterranean Dialogue,” Topics, February 13, 2015. 
Morocco and Tunisia. The EU's partnership with ASEAN countries should also be considered to see if sanctions cooperation is possible, particularly with Myanmar, Vietnam, and Singapore. ${ }^{38}$

The EU should also promote unified intensification of sanctions from other key sender states, especially the US and Japan. The EU should utilize its strong relations with Japan and the US to pursue intensification of sanctions, especially given that both countries are NATO, OECD , and G7 partners. The US is Russia's tenth largest export market ( $\$ 12.6$ billion), and its fourth most significant import market ( $\$ 12.7$ billion), while Japan is Russia's seventh most important import market. ${ }^{39}$ The EU should proactively encourage the US to restrict Russian imports of mineral fuels, oils, and distillation product (valued at $\$ 4.8$ billion total), and restrict US exports aircraft and spacecraft, nuclear reactors and machinery, and vehicles (valued at \$7 billion total). ${ }^{40}$ The EU should proactively encourage Japan enhance restrictive measures to reduce Russian imports of mineral fuels, oils, and distillation products, which is valued at $\$ 9.5$ billion total and accounts for $76.6 \%$ of all imports from Russia. ${ }^{41}$ Furthermore, the EU should also encourage Japan to enhance restrictive measures on exporting vehicles ( $\$ 4.2$ billion),

\footnotetext{
${ }^{38}$ European Commission, "Association of South East Asian Nations (ASEAN)," Countries and regions, May 5, 2020.

39 Department for International Trade (DIT) and the Department for Business, Energy and Industrial Strategy (BEIS) of the United Kingdom. "Russian Federation - Top-10 export markets for goods in 2018." Russian Federation exports of goods in 2018. Based on UN Comtrade data (2020).

40 Department for International Trade (DIT) and the Department for Business, Energy and Industrial Strategy (BEIS) of the United Kingdom. "Russian Federation - Top-10 exports of goods to USA in 2018." Russian Federation exports of goods in 2018. Based on UN Comtrade data (2020); Department for International Trade (DIT) and the Department for Business, Energy and Industrial Strategy (BEIS) of the United Kingdom. "Russian Federation - Top-10 imports of goods to USA in 2018." Russian Federation exports of goods in 2018. Based on UN Comtrade data (2020).

${ }^{41}$ Department for International Trade (DIT) and the Department for Business, Energy and Industrial Strategy (BEIS) of the United Kingdom. "Russian Federation - Top-10 exports of goods to Japan in 2018." Russian Federation exports of goods in 2018. Based on UN Comtrade data (2020).
} 
nuclear reactors and machinery ( $\$ 1.8$ billion), and electrical goods ( $\$ 709.9$ million). ${ }^{42}$ US, Japan, and South Korea can play crucial roles together in undercutting Russia's three most significant import goods valued at $\$ 97.2$ billion - 40.5\% of Russia's total imports - since the US, Japan, and South Korea account for $11.5 \%$ of nuclear goods, $33 \%$ of vehicle goods, and $8 \%$ of all electrical imported goods.

The EU should also consider the option of further leveraging international institutions to influence Russia's foreign policy. In following this strategy, the EU should pursue ongoing advocation for limiting Russia's access to international organizations such as the Council of Europe and the G7. The EU should also consider supporting Ukraine's case in the International Court of Justice (ICJ), by any legitimate and legal means possible. Ukraine has filed against Russia to the ICJ, alleging that Russia violated its obligations under the International Convention for the Suppression of the Financing of Terrorism and International Convention on the Elimination of All Forms of Racial Discrimination. ${ }^{43}$ Ukraine brought forward evidence for the first allegation suggesting that "Russia supplied funds, weapons and training to illegal armed groups [...] and supported the July 2014 downing of Malaysia Airlines Flight MH17". ${ }^{44}$ As for the latter allegation, Ukraine brought forward evidence to suggest that Russia has discriminated and mistreated Crimean Tartar and ethnic Ukrainian communities in Crimea, which was annexed by Russia in 2014. As of late 2019, the ICJ ruled in favour of Ukraine, deciding to move further

\footnotetext{
${ }^{42}$ Department for International Trade (DIT) and the Department for Business, Energy and Industrial Strategy (BEIS) of the United Kingdom. "Russian Federation - Top-10 imports of goods from Japan in 2018." Russian Federation exports of goods in 2018. Based on UN Comtrade data (2020).

${ }^{43}$ UN News, "Top UN court will consider Ukraine allegations against Russia of treaty violations," United Nations, November 8, 2019.

${ }^{44}$ Ibid.
} 
with its claims. This would follow the EU's current sanctions policy objectives on the annexation of Crimea and destabilization of Ukraine.

The EU should consider consistently increasing pressure through diplomatic and economic channels, while seeking to negotiate with Russia continuously. Being that the UNSC P5 member states includes a key EU member state (France), and two key partners of the EU (UK and the US), the should consider leveraging the three UNSC members to add additional pressure to Russia, and even use the UNSC veto as part of a larger negotiating strategy. The Normandy Format - which brings together Russia, Ukraine, France and Germany — has had some success in creating some common ground and cease-fire agreements. However, these have never resulted in actual ceasefires or any lasting political settlement. In addition, it is difficult to justify the exclusive nature of the Normandy Format as proper representation in negotiations, when the vast majority of sender states are not represented. ${ }^{45}$ To foster inclusive negotiations and exemplify a unified front to the target state, the EU should consider proactively seeking to lead the negotiations with Russia given that it is the most significant sender state. ${ }^{46}$

\section{Other Strategic Options for the EU}

As for other strategic options, the EU may utilize positive sanctions, offer a compromise to negotiate an agreement, change from consensus-based sanctions policy to a qualified majority vote (QMV), and/or respond with military options. The EU could consider potential positive

\footnotetext{
${ }^{45}$ Simon de Galbert, "The Impact of the Normandy Format on the Conflict in Ukraine: Four Leaders, Three Ceasefires, and Two Summits," Center for Strategic and International Studies, October 23, 2015.

46 Please refer to Chapter 1 for why the EU is the most significant sender state. In brief, it has the largest trade turnover, economic and financial ties, and longest shared history.
} 
sanctions, also known as incentives, to help conclude negotiations with Russia. Examples of positive sanctions could include subsidies, preferential tariffs, investment guarantees, foreign aid, and preferential taxation of foreign investment. ${ }^{47}$ Studies have found that incentives could add to the effectiveness of sanctions, but often dependent on the case and are widely hardly significant. 48 However, it can play a key role in concluding negotiations and to preserve a positive image for the target state both domestically and internationally. It would be able to present the agreement as win for either side, with each hoisting the agreement as a major win for its own interests. At the same time, although incentives can play a positive role in concluding negotiations, creating concessions, and removing sanctions, it could also be a harmful precedent for the future and could have a negative signal to the international community.

If the EU decides to provide incentives to Russia to concede, then the EU risks losing its developed relationship with Ukraine by seemingly "rewarding" Russia for its interfering foreign policy, and setting the precedent for Russia or other countries to use the strategy of reward manipulation with the EU. Since the EU supports Ukraine's territorial integrity and denounces Russia's foreign policy in this field, providing incentives to Russia for undoing those actions could signal to Ukraine and the EU's allies that the EU is seemingly "rewarding" Russia for something that it should have not done in the first place. Accordingly, this leads to the second point of reward manipulation. Seeing that Russia has done something internationally unacceptable and receives an incentive to undo that action, it could lead to a strategy of reward

\footnotetext{
${ }^{47}$ David Baldwin, “Economic Statecraft," In Encyclopedia Britannica, May 22, 2020.

${ }^{48}$ Han Dorussen and Jongryn Mo, "SANCTIONS AND INCENTIVES," Globalization and Armed Conflict Workshop, European Consortium on Political Research, April 15-18, 2020: 17. 
manipulation in the future where a state can carry out a "wrongdoing" and look towards negotiating an incentive with the sender state in the future. ${ }^{49}$ On the other hand, positive sanctions has the potential to play a key role in creating a political settlement in this particular dispute. Furthermore, the EU could look to proposing conditional positive sanctions, which would act as regular incentives, but on the condition that Russia does not commit similar wrongdoings in the future. ${ }^{50}$ These incentives can be fulfilled when Russia commits to the appropriate concessions, continues to follow these concessions, and recognizes that practicing likeminded foreign policy in the future will result in the immediate removal of these incentives. As a result, these conditional positive sanctions can lead to an agreement in this dispute and as continuous positive reinforcement mechanism for Russia to avoid such foreign policy in the future. Moreover, if Russia is to agree to conditional positive sanctions and breaks this conditionality later on, the EU's response to removing incentives will be seen less as imposing negative sanctions but more as Russia losing its incentives that it gained from before.

The EU also has the option of extending diplomatic positive sanctions. ${ }^{51}$ Although sanctions literature focuses on the economic aspects of incentivization with regards to positive sanctions, there is also the option of providing diplomatic incentivization that follows the same

\footnotetext{
49 The strategy of reward manipulation is defined by this paper as the act by one state to commit a wrongdoing, attracting sanctions in the process, and to negotiate positive sanctions (incentives) with the sender state. As a result, the target state profits from positive sanctions as a result of undoing a wrongdoing and returning to the starting point.

50 Conditional positive sanctions are defined by this paper as positive sanctions that are based on the condition that the target state will not practice any similar foreign policy to the one that attracted negative sanctions in the first place. If agreed to, the target state agrees to not practice any likeminded foreign policy in the future, and if the target state breaks this agreement, the sender state will immediately remove positive sanctions.
}

51 Diplomatic positive sanctions are defined by this paper as positive sanctions that focus on diplomatic incentivization, equal but opposite to negative diplomatic sanctions. Positive diplomatic sanctions use the same method (diplomacy) but with opposite means - instead of diplomatic punishment, it uses the means of diplomatic incentivization. 
methodology of positive sanctions. Just as there are economic and diplomatic negative sanctions to punish, positive sanctions also incorporate economic and diplomatic means of incentivization. In this case, the EU has option to propose diplomatic incentives such as creating favourable conditions for Russian diplomats and missions through increased personnel allowance, financing, or decreased visa restrictions. More significantly, the EU can propose Russian admission to the G7 or increased EU-EEU cooperation as diplomatic positive sanctions. Of course, the same risks apply as they do in positive economic sanctions noted above.

The EU also has the option to compromise in order to conclude an agreement with Russia. This may result in some concessions from Russia, a conclusion to the dispute, and the removal of sanctions, but it may create similar risks to positive sanctions and more. In addition to the risks presented by positive sanctions, compromising to the target state may produce an even more dangerous precedent as it recognizes that the sender state is willing to compromise its sanctions regime to end a dispute. Consequently, future EU target states may pursue long-term sanctions regimes and look towards the EU compromising rather than conceding to sanctions' objectives - which includes Russia. Also, compromising will undermine the EU's sanctions objectives, and may undermine the main sanctions objective - resulting in the failure of the sanctions regime. For example, the EU has the option to compromise by recognizing Crimea as part of the Russian Federation and successfully drawing concessions from Russia to stop destabilizing eastern Ukraine. This would end the sanctions regime, conclude the dispute, help initiate the normalization of relations, and increase the likelihood of cooperation. Nonetheless, 
the EU also faces major risks as mentioned above, plus the risk of losing its partnership with key allies including the US, Canada, Australia, New Zealand, and others.

The EU also has the possibility of changing its consensus-based sanctions policy to a QMV, which could assist in enabling harsher restrictive measures against Russia. A consensus vote requires unanimity from EU members, while a QMV only requires $55 \%$ of member states to vote in favour (15 members) and supported by members representing at least $65 \%$ of the EU total population..$^{52} \mathrm{~A}$ current consensus vote by the EU requires that all members agree to extending sanctions and to certain expansions of the sanctions package. Thus, the sanctions package is likely to expand slowly to ensure that it does not damage any states interests - meaning that sanctions are prevented if one state's interests are not grossly unrepresented. However, under a QMV, the EU would likely be able to administer more extensive sanctions, like oil and gas trade restrictions. ${ }^{53}$ Many member-states oppose QMV for deciding on sanctions policy since: a) "larger" members would have greater voting power and "smaller" members may not be represented, b) eurosceptic governments would reject further EU "encroachment" on their sovereignty, and c) those members who benefit from certain target states, such as Russia, would not be able to preserve their beneficial ties with Russia. ${ }^{54}$ Enforcing a QMV and implementing more extensive sanctions may cause detrimental damage to certain EU member states and intensify discord between them. Due to the EU's lack of a stronger common foreign policy often created by divisions or conflicting national interests, the European Commission has proposed to

\footnotetext{
${ }^{52}$ Council of the European Union, “Qualified majority," Voting System, March 23, 2020.

${ }^{53}$ Leonard Shuette, "Should the EU make foreign policy decisions by majority voting?" Center for European Reform, May 2019.

${ }^{54}$ Ibid, 1.
} 
extend QMV to three policy fields within the EU's CFSP, including sanctions, and argued that these reforms would not require changes to EU treaties. ${ }^{55}$ If successfully done, larger members or less eurosceptic governments should utilize this opportunity to consider the interests of other groups, to enforce more extensive sanctions while also minimizing the costs to those members.

${ }^{55}$ Leonard Shuette, "Should the EU make foreign policy decisions by majority voting?" Center for European Reform, May 2019: 1. 